\title{
Ericaceae in Malesia: vicariance biogeography, terrane tectonics and ecology
}

\author{
Michael Heads
}

\begin{abstract}
Heads, Michael (Science Faculty, University of Goroka, PO Box 1078, Goroka, Papua New Guinea. Current address: Biology Department, University of the South Pacific, P.O. Box 1168, Suva, Fiji. Email: heads_m@usp.ac.fj) 2003. Ericaceae in Malesia: vicariance biogeography, terrane tectonics and ecology. Telopea 10(1): 311-449. The Ericaceae are cosmopolitan but the main clades have well-marked centres of diversity and endemism in different parts of the world. Erica and its relatives, the heaths, are mainly in South Africa, while their sister group, Rhododendron and relatives, has centres of diversity in N Burma/SW China and New Guinea, giving an Indian Ocean affinity. The Vaccinioideae are largely Pacific-based, and epacrids are mainly in Australasia. The different centres, and trans-Indian, trans-Pacific and trans-Atlantic Ocean disjunctions all indicate origin by vicariance. The different main massings are reflected in the different distributions of the subfamilies within Malesia. With respect to plant architecture, in Rhododendron inflorescence bracts and leaves are very different. Erica and relatives with the 'ericoid' habit have similar leaves and bracts, and the individual plants may be homologous with inflorescences of Rhododendron. Furthermore, in the ericoids the 'inflorescence-plant' has also been largely sterilised, leaving shoots with mainly just bracts, and flowers restricted to distal parts of the shoot. The epacrids are also 'inflorescence-plants' with foliage comprised of 'bracts', but their sister group, the Vaccinioideae, have dimorphic foliage (leaves and bracts). In Malesian Ericaceae, the four large genera and the family as a whole have most species in the 1500-2000 m altitudinal belt, lower than is often thought and within the range of sweet potato cultivation. The same belt is also most diverse for ferns, birds-of-paradise and bowerbirds. Distribution maps of Malesian Ericaceae are presented, with related species indicated. Concentric patterns of distribution are frequent and could be attributable to evolution around shrinking seas. In New Guinea the main axial range is a composite structure, with the southern part formed by the old Australian craton and the northern and eastern parts formed from 32 tectonostratigraphic terranes or microplates. These formed independently and then docked with each other and the craton. The tectonic boundary between the craton and the accreted terranes is also an important biogeographic boundary. Many taxa have distributions linking different accreted terranes but are not on the craton. Movement and integration of island arcs and more substantial terranes has led to complex patterns of disjunction throughout Malesia, but there is an underlying parallel-arc structure, seen clearly in New Guinea. The tectonic provinces in Borneo are also reflected in the two main biogeographic tracks: Kuching--Kinabalu and Kutei Mts./Mt. Kemul-Kinabalu, the Lupar River boundary and the Meratus Mts. centre. The islands of the Riouw Pocket (Corner 1978a) are notably surrounded by many groups which are absent there, including mangrove and Ericaceae species. However, other mangrove and coastal taxa occur along a CW Sumatra - Riouw Pocket - SW Borneo track. In Malesia, Rhododendron and Vaccinium mangrove and coastal species are mainly restricted to the west, in Sumatra-Borneo and often the Riouw Pocket; and are represented in New Guinea by related montane taxa. Van Steenis $(1963,1984)$ drew attention to mangroves uplifted by tectonics and the Malesian Ericaceae in general could be largely derived from mangrove forms. Rhododendron species occur as epiphytes in mangrove, and many Ericaceae occur in calcareous and saline sites. The very rapid rates of tectonic uplift occurring in New Guinea would raise a mangrove community or a coastal 'padang' to the upper montane zone in just one million years.
\end{abstract}


CONIENTS

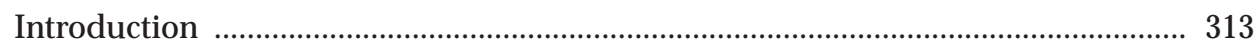

Affinities of Ericaceae with other families ............................................................ 313

Ericaceae subfamilies and their biogeography ..................................................... 314

Conclusion on biogeography of the subfamilies .................................................. 319

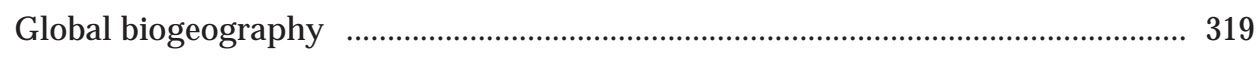

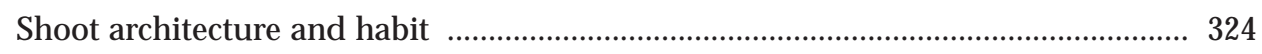

Ericoid shrubs as largely sterilised inflorescences ................................................. 325

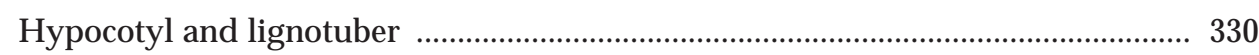

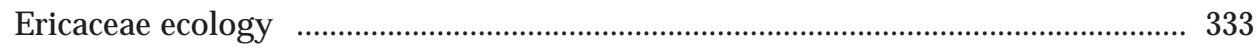

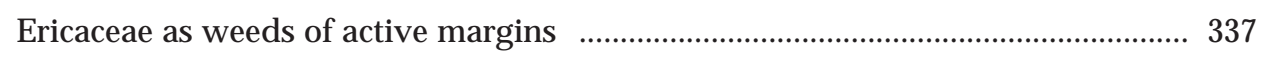

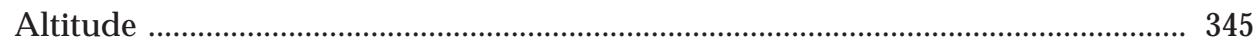

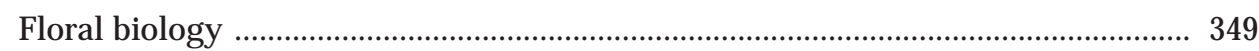

Ericaceae in Malesia - systematic treatment ....................................................... 349

Biogeography of the Malesian mountain flora and the myth of

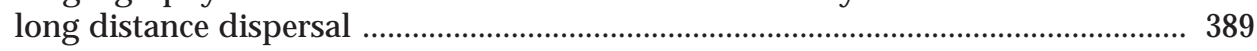

Biogeography of regions in Malesia ......................................................................... 394

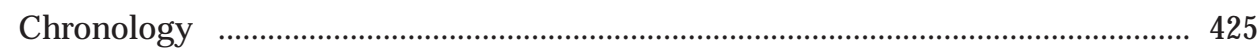

Mangrove ancestry of Malesian Ericaceae ............................................................ 426

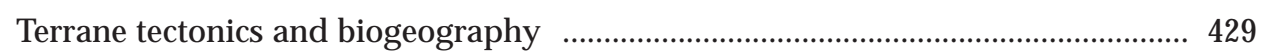

Centres of origin, chronology, and adaptation ........................................................ 431

Rhododendron: adaptive radiation or non-adaptive amalgamation? ........................ 432

Conclusions: biogeography and evolution in Ericaceae ........................................ 434

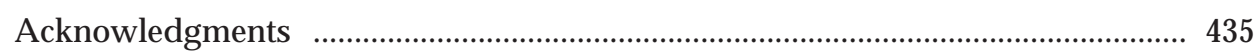

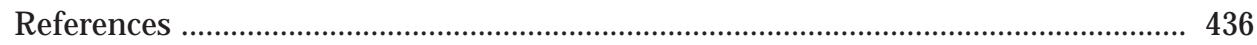

'Fortune reigns in gifts of the world, not in the lineaments of nature'.

- Shakespeare, As You Like It. 


\section{Introduction}

Rhododendron L. (c. 900 species) and Erica L. (c. 860 species) are the largest genera in Ericaceae. Both are ecologically important and widely cultivated in Europe, but they are not highly speciose there. Erica has a clear centre of diversity in Cape Province, South Africa, and Rhododendron has one in N Burma/SW China and a second in New Guinea.

Ericaceae (including Epacridaceae) are hardy plants, better able than most families except grasses to withstand the environmental extremes of mountain tops, arctic conditions, volcanoes, swamps, rocks, tree trunks and branches, and acid, oligotrophic soil which is often sandy or peaty. However, apart from a few saprophytic members they nearly all require high light levels, and many need a good supply of moisture.

This paper deals with the Ericaceae of the lands between Asia and Australia (the East Indies) that botanists refer to as Malesia.

\section{The affinities of Ericaceae with other families}

From the 1960 s to the 1980 s the Russian-American (Takhtajan-Cronquist) classification of the dicotyledons (e.g. Cronquist 1981) was widely taught and very influential. However, the three largest groupings — Dilleniidae, Rosidae and Asteridae - were often not adopted by tropical botanists. Philipson (1974, 1975, 1977), for example, placed Ericales (Dilleniidae), and Cornales, Araliales, and Pittosporaceae (Rosidae) together with the Asteridae on the basis of ovule morphology. (Philipson revived and extended Warming's early observations which had fallen into disrepute through van Tieghem's uncritical and complete reliance on them). Philipson (1977) also removed Ebenales, Primulales and Theales from Dilleniidae to a position near this group, and a broad Ericales, including these orders, is also supported by palynology.

This vast group of all the Asteridae plus many 'dilleniid' and 'rosid' families comprises about a third of the dicots (Olmstead et al. 2000). Although Philipson's work drastically undermined the Cronquist-Takhtajan groups, it was soon taken up by Dahlgren (1980). (Anderberg's 1992 claim that the new grouping of Ericales s.l. with Asteridae was 'definitely an innovative approach' of Dahlgren was perhaps a little over-enthusiastic).

Recent results from molecular studies are much more closely aligned with the Philipson-Dahlgren system than with the Russian-American classification: for example Olmstead et al. (2000) indicated a broad Ericales (including Actinidiaceae, Primulales, Ebenales, Theales and Lecythidaceae etc.) as the sister group of the Euasteridae.

It is interesting that both the Philipson-Dahlgren ideas and the DNA cladograms resemble the classic systems of a century ago rather than the long detour of the Russian-American system. Bentham and Hooker's (1862-1883) Gamopetalae and Engler and Prantl's (1887-1914) Sympetalae both included all of the Ericales, Ebenales and Primulales with 'Asteridae'. It seems rather confusing to call this very large group 'Asteridae' when it is nothing like the original Asteridae and is much more like Sympetalae, an older and very well-known name.

A study of $r b c \mathrm{~L}, a t p \mathrm{~B}$ and 18S RNA in 560 angiosperms (Soltis et al. 2000) had Ericaceae sister to Actinidiaceae, and this pair with Clethraceae, Cyrillaceae and insectivorous Sarraceniaceae. Roridulaceae of South Africa was sister to a very large Ericales (including Theaceae, Sapotaceae, Ebenaceae, Myrsinaceae, etc.). 
In a study of $r b c \mathrm{~L}$ in 589 dicots, Savolainen et al. (2000) had Ericaceae sister to Roridulaceae, as was earlier proposed by Anderberg (1992). This pair is sister to a clade comprising Actinidiaceae and the Sarraceniaceae (cf. Judd and Kron 1993). Sister to all these is a clade comprising Cyrillaceae, Camellieae and Clethraceae. Ericales as a whole again included Theaceae, Sapotaceae, Ebenaceae and Myrsinaceae. 'C.A.R.-G.' (in Sleumer 1966) pointed out the strong similarities in wood anatomy between Ericaceae and Theaceae, families often associated ecologically in the montane tropics.

Roridula L., a possible sister of Ericaceae, comprises two shrub species of southwest Cape Province, South Africa. The leaves bear tentacle-like, glandular trichomes superficially similar to those of Drosera, and Roridula was long regarded as insectivorous. However, the secretion proved to contain resins rather than enzymes (Lloyd 1976). Roridula also contains latex with a relatively high percentage of rubber. $R$. gorgonias grows in Sphagnum-covered seeps on cloudy montane slopes, whereas $R$. dentata has some xeromorphic features and occurs on drier, sandy flats (Carlquist 1976). Soils in both habitats are highly acidic and low in nitrates, as in standard Ericaceae habitat. Roridula, like Ericaceae, is mycorrhizal, which may have permitted the loss of any digestive function in the secretion.

In a study of five genes (Anderberg et al. 2002), a strict consensus tree included an 'ericoid clade' in which a group Actinidiaceae, Roridulaceae and Sarraceniaceae was sister to a group Clethraceae, Cyrillaceae and Ericaceae. The 'ericoid clade' as a whole shows a strong centre around the Pacific Ocean: Actinidiaceae comprises Actinidia Lindl. of E Asia, Saurauia Willd. of tropical Asia and America, and Clematoclethra Maxim. in west and central China. Clethraceae (comprising Clethra L. only) has a classic trans-Pacific track, China to New Guinea, and SE United States to Colombia and Brazil, with one species in Madeira. Cyrillaceae comprises two genera of the SE United States, and Purdiaea Planch., mostly in Cuba, and also in central and South America (Mexico, Colombia, Brazil).

\section{Subfamilies of Ericaceae and their biogeography}

Hutchinson (1959) emphasized the 'great concentration' of Erica in southern Africa and Rhododendron in W China. Cullen (1978) reiterated this: the two genera show 'remarkable concentrations of species in relatively small areas. Rhododendron has a massing of about 700 species in the area where China, Tibet, Burma, and Assam all meet - the area where the great rivers of eastern Asia (the Brahmaputra, Irrawaddy, Salween, Mekong and Yangtse) break though the Himalayan chain. The genus also has a secondary centre of almost 300 species in New Guinea ['Malesia' is possibly meant] ... Erica has an even more remarkable concentration of species in southern Africa, where about 450 species occur, many of them restricted to the Cape Province ... '.

Cullen (1978) pointed out that in Ericaceae Gaultheria also has an interesting distribution as it rings the Pacific Ocean almost completely.

Cullen also noted that Ericaceae s.s. are absent from most of Australia: there are only two Agapetes and two Rhododendron species in NE Queensland, and five Gaultheria in Tasmania and the highlands of Victoria/New South Wales (Beadle 1981). There are no Ericaceae s.s. in Western Australia, despite many suitable environments there; conversely, Epacridaceae are most diverse in SW Western Australia and SE Australia/New Zealand.

Cullen (1978) concluded that distributions of the main Ericaceae clades as outlined 'present challenges to plant geographers and students of evolution, and no generally acceptable explanation of them has so far been proposed.' 
The taxonomy of the Ericaceae is notoriously controversial from family level down, making biogeographic analysis complex. However, DNA results are now appearing for many groups, and these tend to give clear patterns of vicariance. In particular, the subfamily or equivalent clades in Ericaceae indicated in Kron's $(1996,1997)$ studies have vicariant main massings, implying they have probably evolved by allopatric evolution during a phase of immobilism. The main clades in the family, with the location of their main species massings (Fig. 1), are the following.

Enkianthus Lour., a genus of shrubs and small trees in the Himalayas, southern China and Japan, is sister to all the other Ericaceae (Anderberg 1992, 1993, 1994, Judd and Kron 1993, and subsequent DNA studies).

The next branch is Ericaceae subfam. Monotropoideae s.l. (including Pyroloideae and Arbutoideae), a small group mainly in the Northern Hemisphere (with three genera in Peninsular Malaysia/N. Sumatra, also sister to all the other Ericaceae. Recently Hileman et al. (2001) concluded that the Mediterranean - North American disjunction in this group is the result of mid-Tertiary vicariance on the basis of age of fossils, and so the actual date is at least this age.

The rest of the family comprises two large clades. The first is a large, mainly Indian Ocean clade: (ericoids + 'phyllodocoids') + (rhododendroids + empetroids (formerly Empetraceae)). Ericoideae is mainly in South Africa and also occurs in tropical Africa, Madagascar and the Mascarenes, with a secondary massing, about 20 species, in Europe). The small phyllodocoid branch for Phyllodoce Salisb. and relatives has several monotypic or oligotypic genera in the Northern Hemisphere, especially the United States. The only large genus is the basal Bejaria L. with 30 species in tropical and subtropical America, indicating a possible Atlantic Ocean baseline for the clade.

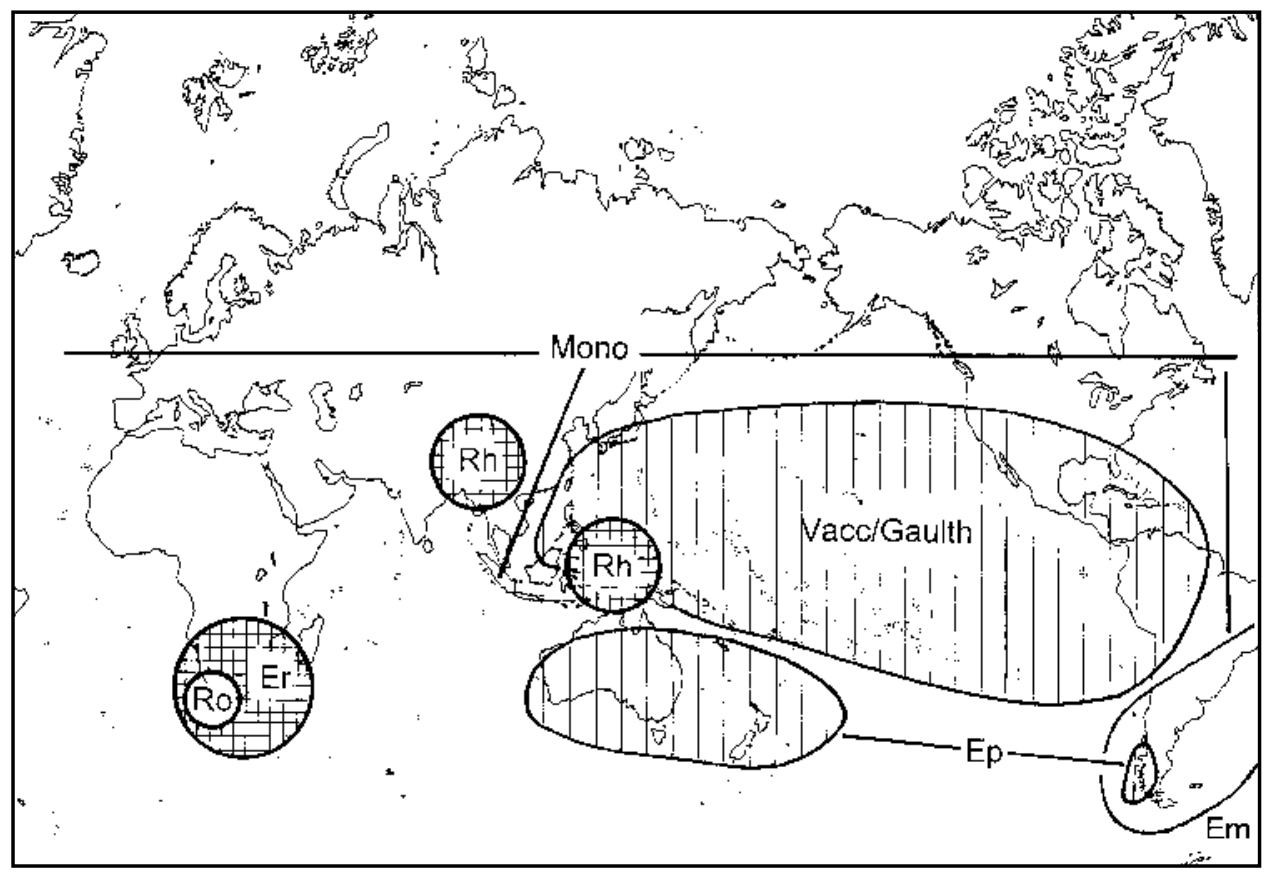

Fig. 1. Main centres of diversity in Roridulaceae (Ro), ericoids (Er), rhododendroids (Rh), Vaccinioideae (Vacc/Gaulth), epacrids (Ep) and Empetraceae (Em). 
Rhododendroideae has main massings in N Burma/S China and New Guinea, and is also in Eurasia (one or two species of Rhododendron occur as far south as the Nilghiris and Sri Lanka) and America. The 'Empetraceae' branch is in southern South America and the Northern Hemisphere.

The ericoid-rhododendroid clade is sister to the second large group in the family, the Vaccinium-Gaultheria-Lyonia-epacrid clade, referred to here as subfam. Vaccinioideae (Kron, Judd and Crayn 1999). Unlike the first group, this has a large, if not the main, massing around the Pacific. Epacrids, formerly the family Epacridaceae, are now seen as the sister of the other vaccinioids. They are in Australasia and Chile, with a few species in the Pacific and SE Asia and possibly as fossils in South Africa (Namaqualand) (Coetzee 1993).

\section{Ericoideae}

Oliver (1991, 2000) has sunk 23 genera into a broadened Erica which now covers virtually all of the subfamily's range. Oliver (1989) accepted just three genera in Ericeae: Calluna Salisb. (one species widespread in Europe to the Urals), Erica s.l. (860 species, Africa and Europe) and Daboecia D.Don, Atlantic Europe and Azores. Oliver (1989) gave a very useful map of Ericeae (although the only record for West Africa was mapped in northern Ghana instead of at the Ivory Coast/Liberia/ Guinea border). Outside mainland Africa Erica also ranges (with 'Philippia' only) in Madagascar (45 species, including some on calcareous rocks), the Comoros, and the Mascarenes (Perrier de la Bâthie 1927). 'Philippia' also occurs on mainland Africa and at sea-level on Mafia Island off Tanzania (at $8^{\circ}$ lat.), a site which is neither temperate nor tropical-montane, where most Ericaceae occur. There is a second centre of Erica in Europe (20 species).

In southern Africa there is a dramatic increase in the number of Erica species towards the southern tip of the continent which Oliver (1991) called 'the most remarkable distribution phenomenon in the plant kingdom' and the concentration of Erica species in the SW Cape is 'unequalled [for any genus] anywhere in the world.'

Of 657 southern African Erica species, Schumann et al. (1992) illustrated 468 from South Africa. They cited 625 species present in southern Cape Province, and 235 in Caledon District alone. The term Caledon Centre (Croizat 1965) has been taken up by most authors for this region, one of the most dramatic centres of diversity in the world.

At a finer scale than that of district, Oliver et al. (1983) mapped species numbers of Cape genera in $1 / 4^{\circ} \times 1 / 4^{\circ}$ grid squares (about $20 \mathrm{~km} \times 20 \mathrm{~km}$ ), and showed Erica reaching a maximum at 175 species in a square just east of Cape Town which includes the town of Somerset West and the Hottentots-Holland Mountains. The same square is richest for Ericaceae as a whole, Restionaceae, Diosmeae (Rutaceae) and Bruniaceae, first equal for Penaeaceae, and is adjacent to the richest square for Proteaceae.

Other Ericoideae are of special morphological interest. In 'Nagelocarpus' Bullock, monotypic in the SW Cape, the ovary is half-inferior to the corolla and stamens but superior to the calyx - N.E. Brown (1905) described this as unique in the vegetable kingdom. Oliver (1991) illustrated bizarre forms of 'Philippia' from Madagascar in which the very large stigmatic lobes form an immense funnel that can take up the whole mouth of the corolla, similar to species in Erica sect. Arsace of South Africa which also have very large, shield-like stigmas. These are wind-pollinated and often form a dominant part of the 'fynbos' or heath.

Oliver (1991) concluded that 'explanations for the great concentration of so many species of Erica just in the Cape have not been forthcoming'. In this paper the concentration is attributed to activity early in the history of the Ericales along the major 
tectonic features, the Zwartberg and Cedarberg Fold Belts (cf. Craw et al. 1999). These run at right angles to each other and intersect at the SW Cape, by the Caledon Centre. This massing, the high diversity in East Africa and Madagascar (45 species), and the occurrence at the Mascarenes all indicate an old SW Indian Ocean centre vicariant with the NE Indian Ocean centre in Rhododendron and SE Indian Ocean centre in epacrids. Oliver (1991) commented that 'Ericoideae were always put forward as a clear-cut example of a northern [sub]family because of the strong connection to the north and none to the west or east. This is in contrast to the families Proteaceae or Restionaceae.' However, DNA studies emphasize instead the vicariance of Ericoideae with Rhododendroideae and Vacciniodeae/epacrids in the east, and Bejaria etc. in the west.

\section{Rhododendroideae}

The ericoid - rhododendroid clade basically follows an Africa-Eurasia-America track. Rhododendron itself has a primary centre of diversity in the Sino-Himalaya region and a second in New Guinea, like groups such as Ficus sect. Sycidium (Corner 1938, 1963) and also extends to Europe and North America (south to the US/Mexico border). The clade is notably absent from the central and south Pacific, in contrast with the vaccinioidepacrid clade, and has only two Rhododendron species in Queensland and none in the mountains of New Caledonia or New Zealand. Members of this group that are remarkably ericoid vegetatively include Ledothamnus Meissn. in Venezuela/Guyana and Rhododendron ericoides on Mount Kinabalu.

\section{3. 'Empetraceae'}

This is the sister group of Rhododendroideae and here the flowers are 3-merous, unisexual and wind-pollinated. The group ranges throughout the Northern Hemisphere north of lat. $40^{\circ} \mathrm{N}$, in bogs, moors, and pine barrens. However, Empetrum is also in the Southern Hemisphere, from the southern Andes, the Falkland Islands, Juan Fernandez and Tristan da Cunha. The north-south disjunction is aligned along the Mid-Atlantic Ridge. There are three genera: Empetrum L. holds the family range, Ceratiola Michx. is a SE United States monotype, and Corema D.Don occurs in eastern North America, the Azores, the Canary Islands, and SW Europe in a classic trans-Atlantic pattern.

\section{Vaccinioideae (incl. Gaultheria L. and Lyonia Nutt.)}

Vaccinioideae traditionally includes the Ericaceae with an inferior ovary, many of which are found around the Pacific region. Vaccinium is widespread around the world with about 450 species, especially in the north, but has over half its species (242) in Malesia, and half of these are in New Guinea. In South America it is not found south of Bolivia (Cochabamba), and in Chile it is replaced by epacrids (Lebetanthus Endl.). In Africa it has only half a dozen species and occurs in southern Africa only in Malawi (one species) and eastern Transvaal, near Barberton (one species). South of here it is replaced by the great diversity of Erica.

Vaccinium and its immediate relatives, the tribe Vaccinieae D.Don, comprise 30-35 genera that are especially diverse in southeast Asia and Malesia, and Central and South America (Kron, Fuller et al. 1999). Stevens (1971) concluded that many of the South American genera share a complex of anatomical characters with the Malesian genera Costera J.J.Sm., Dimorphanthera F.Muell. and Agapetes subg. Paphia (Seem.) Stevens. In the Vaccinieae, Atkinson et al. (1995) found diploids in western Malesia and mainland Asia, whereas polyploids are recorded from New Guinea, Australia, and the Neotropics in a trans-Pacific disjunction. 
Kron, Fuller et al. (1999) concluded that Vaccinieae are monophyletic, although Agapetes and Vaccinium as currently accepted are both polyphyletic. In a possible Atlantic Ocean affinity (cf. Empetraceae), Vaccinium sect. Neurodesia of the Andes and North America may be close to $V$. sect. Cinctosandra of Africa and Madagascar. In Vaccinium, the group containing Dimorphanthera and Agapetes subg. Paphia (both diverse in Malesia) may be more closely related to New World Vaccinieae than to the other Old World taxa in a trans-Pacific affinity, although the data support for this is still weak (Kron pers. comm., in press).

Another Pacific group, Gaultheria and relatives, has often been treated with Vaccinieae, and this is supported by Kron, Judd and Crayn (1999) and Kron, Fuller et al. (1999). Camp (1947) mapped the distribution of this group as 'the Gaultheria ring', and this follows the plate margins and the volcanic 'ring of fire' around the Pacific. The Gaultheria group includes the well-supported clade (Kron, Judd and Crayn 1999):

Gaultheria L. (incl. Pernettya Gaudich.). Circumpacific, also west to W Himalayas and S India, east to E US and E Brazil;

Diplycosia Blume. Malesia (throughout);

Tepuia Camp. Venezuela.

The other genera in the Gaultheria group mainly occur around the north Pacific.

A third Pacific affinity, the Lyonia group, was accepted by Kron, Judd and Crayn (1999) as sister to the Vaccinium-Gaultheria group (cf. Stevens 1971). Lyonia itself occurs in East Asia, Malesia (only in Peninsular Malaysia) and North America, Craibiodendron W.W.Smith is in SE Asia, and Pieris D.Don is in East Asia and North America. The Lyonia group thus ranges around the north Pacific, complementing the Vaccinium group in the north and central Pacific, and the Gaultheria group wide in the Pacific.

\section{Epacrids}

These shrubs and trees are distinctive through their leaf venation which is branched near the base, parallel and 'open' — almost monocotyledean (Sleumer 1964). In many ways the leaves are similar to bracts. In tribe Richeae, the aptly-named Tasmanian 'grass-tree' and the New Zealand 'pineapple-scrub' are vegetatively much like monocots, and one member, Dracophyllum Labill., was named after Dracaena L. The 'epacrids' were formerly known as Epacridaceae, but now appear to be nested well within Ericaceae, as sister to the other Vaccinioideae (Kron 1996, Crayn et al. 1998, Crayn and Quinn 2000, Kron et al. 1999). Garcin (1890) pointed out that the fruit in Vaccinium is a drupe (the inner epidermis of the pericarp sclerifies), as in many epacrids. Kron, Fuller et al. (1999) concluded that their studies suggest 'possible biogeographic links between the Southern Hemisphere taxa of Ericaceae s.l.'.

Within the epacrids (Watson 1967, Crayn et al. 1998) the tribe Prionoteae in Tasmania and southern Chile is sister to the rest. Oligarrheneae in SW Western Australia in turn is sister to the remaining five tribes. All these five tribes are shared by Australia and western South Island, New Zealand. Of the five, Richeeae also extends to New Caledonia and has important endemism on the Chatham Islands, and Styphelieae ranges widely, but with few species, in the Pacific and Malesia north to Vietnam. The epacrids are thus centred around SW Western Australia - southern Tasman Sea Chile, and are poorly represented in Malesia. They are not present in the Bismarck Archipelago at all (where there are five Rhododendron species), and in the geographical Solomon Islands they are only on Bougainville with a single species (Sleumer 1964). 
In the Styphelieae Sleumer (1963) sunk several genera (Astroloma R.Br., Cyathodes Labill., Leucopogon R.Br. and Melichrus R.Br.) under Styphelia (G.Forst.) Sm. This was not accepted by many Australasian botanists, and following detailed morphological studies Weiller (1996a,b,c, 1999) accepted the old genera and also described new ones. However, beyond the basal Pentachondra, none of the branches in the Styphelia group (which involve the genera synonymised by Sleumer) are supported by molecular data (Crayn et al. 1998, Crayn and Quinn 2000). In fact these data may even support extending Sleumer's lumping to include additional genera in a broad Styphelia.

Coetzee (1993) reported that pollen evidence from the sediments of the Arnot kimberlite pipe in Namaqualand (western South Africa) indicate the occurrence there during the Paleocene of an 'open-canopied dry subtropical forest with an understorey of Ericaceae, Epacridaceae, Thymelaeaceae, and Restionaceae'. This rather modern-sounding community (the understorey resembles assemblages in, for example, SW New Zealand) ties the epacrids to the most important centre for the family, in South Africa.

\section{Conclusion on biogeography of the subfamilies}

In conclusion, the subfamilies of Ericaceae show clear global vicariance of main massings. One of the main subjects of this paper is the relevance of these massings for distributions within Malesia. Analysing the land-snail fauna of Vanuatu, Solem (1958) recognised three elements which can also be seen in Malesian Ericaceae: PaleoOriental or Malayan (cf. Rhododendroideae), Southern Relict or Australasian (cf. epacrids), and Pacific Ocean or Polynesian (cf. Vaccinioideae). The last element is often ignored (see below), but is crucial for E Malesian groups in particular.

As Hutchinson (1959) wrote, the Ericales are most highly represented in the Southern Hemisphere. However, there are also important centres in the Northern Hemiphere, such as Japan, SE United States and Europe, and it is probably not a question of migration between one and the other, but rather of independent evolution. In fact, there is no evidence indicating a restricted centre of origin of the family Ericaceae followed by migrations; the complex is more simply derived by subdivision of an already global ancestral complex. Roridula and Erica in SW Cape Province, Rhododendron in Burma - New Guinea, the Vaccinioideae around the Pacific, and epacrids around the Tasman Sea all indicate Gondwanic origins for the group (although there are no direct Madagascar - Sri Lanka/India links).

It should be noted here that a 'basal' group is simply a small sister group, it does not imply that the 'basal' group is the ancestral group from which the others were derived, or that it has a 'primitive' morphology, or that it occurs at the 'centre of origin'. For example, Roridula might be sister to Ericaceae, but this is not evidence that Ericaceae had a centre of origin in South Africa and then migrated by physical movement across the world. Nevertheless, the South African region is clearly crucial in the evolution of the group, and the plants there cannot be secondarily derived from a centre of origin elsewhere.

\section{Global biogeography}

Many other taxa with very different ecology and means of dispersal show distributional similarities to the Ericaceae, across both the Indian and Pacific Oceans. 


\section{Indian Ocean affinities}

Hooker (1860) observed that many 'Indian' groups, such as Melastomataceae, are absent or rare in Australia, while related groups like Myrtaceae are very diverse there. The opposite situation holds in Africa-Asia, where Melastomataceae are rich but there is a surprising lack of Myrtaceae. Likewise, Hooker noted that Campanulaceae are diverse in South Africa, while the related Goodeniaceae and Stylidiaceae are diverse in Australia, and Ericaceae in South Africa are 'represented' (Darwin's term) in Australia by Epacridaceae. These are all examples of vicariance around the Indian Ocean.

The connection between the main massings of Erica (South Africa) and Rhododendron (Burma/Yunnan - New Guinea) is another standard Indian Ocean disjunction, in which India/Sri Lanka are mainly avoided (although there are a few Rhododendron species in the Nilghiris and Sri Lanka).

Clarke (1997) discussed the classic Indian Ocean distribution of Nepenthes L. in Madagascar, Seychelles, Sri Lanka, India, S China and Malesia (by far the most species), the lowlands of far northern Queensland and New Caledonia (Fig. 2). For Clarke, the theory of a centre of origin in SE Asia has 'a number of problems'. For example, 'it seems astounding that no Nepenthes have reached the highlands of northern Australia' (cf. the paucity of Rhododendron there), and this is not explained in the centre of origin model. Clarke continued: 'The second theory, put forward by Danser (1928) ... assumes that Nepenthes is a much older genus, their ancestors having arisen perhaps as much as 70 million years ago ... Nepenthes could have originated at a time when Madagascar, the Seychelles, Sri Lanka and India were breaking away from Gondwanaland ...'. Clarke (1997) found the second theory to be the more plausible.

Malesian palms have both Indian Ocean (Veitchia, Fig. 3) and SW Pacific Ocean (Orania, Fig. 3) disjunctions.

Madagascar-Burma connections occur in many plants, for example: Sleumer (1942) keyed out Desmostachys Planch. (Icacin.) of tropical Africa and Madagascar with Pittosporopsis Craib. of Upper Burma, Yunnan, and Thailand. (The fact that taxa are keyed together does not necessarily mean they are closely related, but it does indicate that some characters are shared).

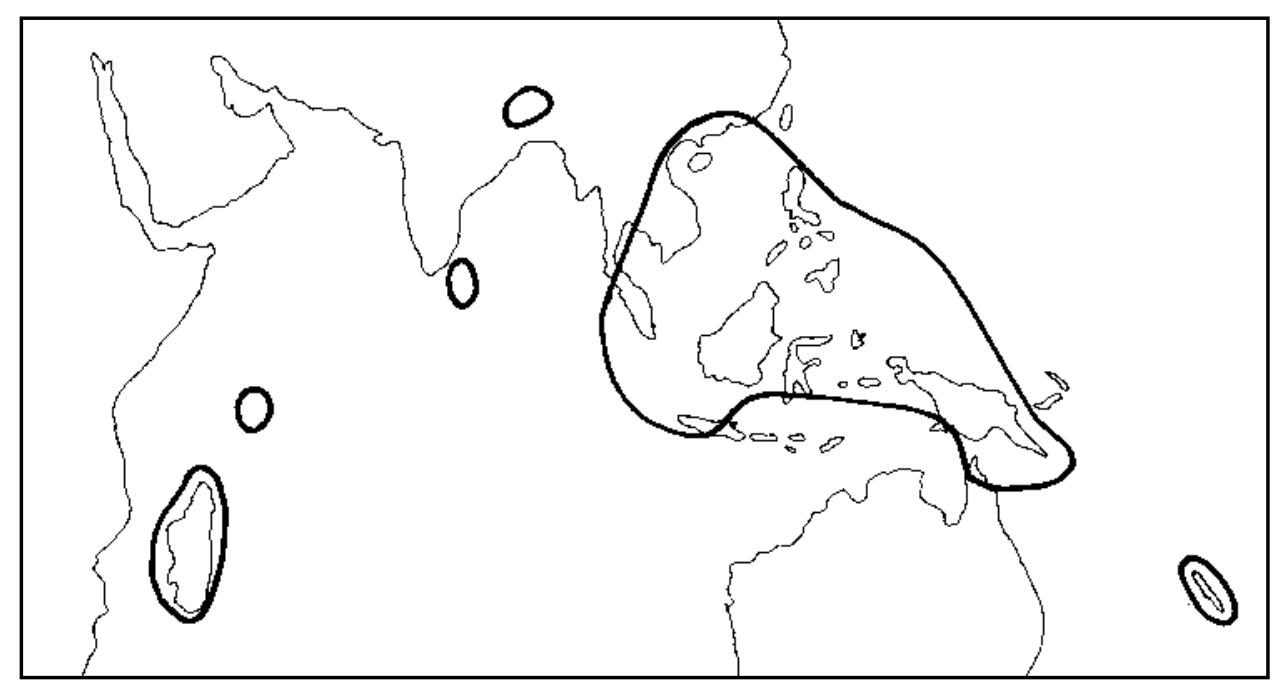

Fig. 2. Nepenthes L. (Nepenth.) (Juniper et al. 1989). 


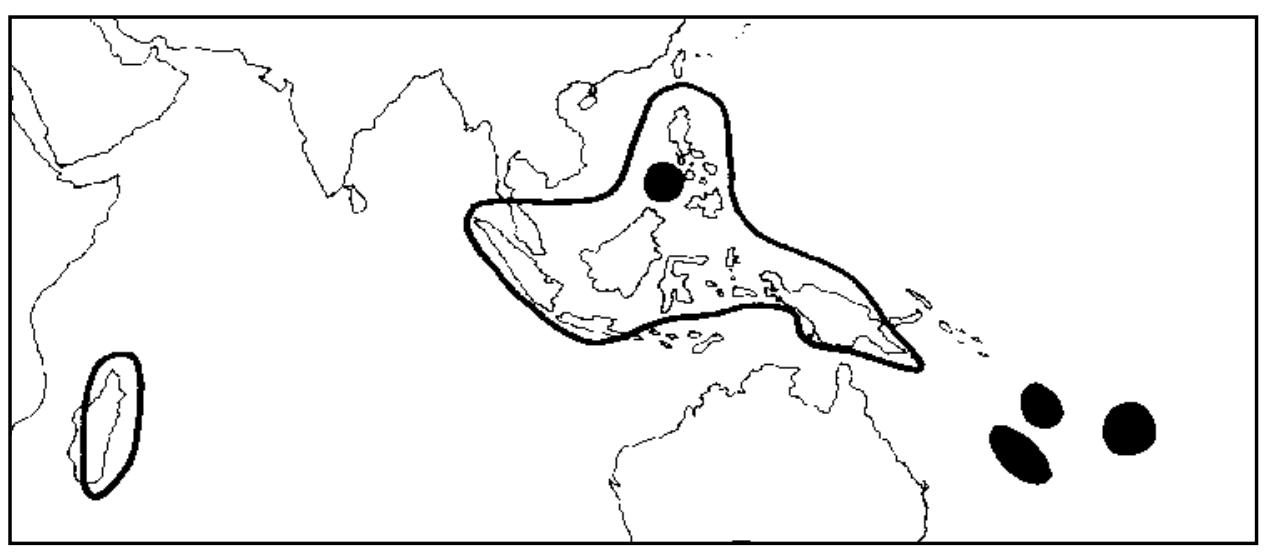

Fig. 3. Orania Zippel. (line) and Veitchia H. Wendl. (black) (Palmae) (Baker et al. 1998).

Afzelia Sm. (Caesalpin.) has seven species in Africa, three in Burma-China, and three in Malesia. (Brenan 1967).

In birds, Gymnobucco (Capitonidae) of Africa is usually placed with Calorhamphus of S Burma, Malaysia, Sumatra, and Borneo (Howard and Moore 1984). Zoonavena (Apodidae) is in Africa, Madagascar, and India to Burma. Raphidura (Apodidae) is in Africa and S Burma to Sumatra, Java and Borneo.

The distance between Aceh and Madagascar is the same as between Aceh and PNG, and both sectors represent important disjunctions. Madagascar-Sumatra examples include the following.

Aralidium Miq. comprises a single pachycaul species endemic to the lowlands of W Malesia: southern Thailand (south of the Kra Isthmus), Peninsular Malaysia, Sumatra, Singapore, Anambas Is., and Borneo (widespread). It was formerly treated in Araliaceae but Philipson and Stone (1980) created a new family, Aralidiaceae, for it. This is supported by DNA studies (Savolainen et al. 2000) in which it appears as the sister group of Melanophyllaceae of Madagascar.

Dapania Korth. (Oxalid.) (Veldkamp 1971) has the same 'remarkable' but 'characteristic' disjunction: West Malesia - Madagascar.

Quassia borneensis Nooteboom (Simaroub.) of peat-swamp forest and lowland rainforest in central Sumatra and Borneo is 'obviously closely allied' to African species (Nooteboom 1964).

In Crossonephelis Baill. (Sapind.), the Madagascar species is 'possibly the most primitive' of the living species (Leenhouts 1973) and seems allied on one hand to the continental African species and on the other to the most widespread and 'least specialised' of the Malesian species, C. palawanicus (Sumatra to New Guinea).

In addition to Madagascar-Sumatra and Madagascar-Burma tracks, many plants illustrate the connections between NE Assam and Malesia (van Steenis 1962b) (cf. Rhododendron), either through N Sumatra (Primula prolifera, cf. Gaultheria) or via Kinabalu and the Philippines (Haloragis micrantha). 


\section{Pacific Ocean affinities}

Even though van Steenis (1962) devoted a long paper to trans-tropical Pacific distributions, accepting significant Polynesian endemism or trans-Polynesian biogeographic connections has generally remained taboo. When they are admitted, trans-central Pacific connections are traditionally explained by long distance dispersal (e.g. Vijverberg et al. 1999, on Microseris D.Don, Compositae) although the same pattern may be shared by many taxa with different means of dispersal, indicating instead a vicariance origin (Chin et al. 1991 on Microseris, marine algae, etc.).

Luteyn (2002) recorded the highest diversity of Neotropical Ericaceae in Antioquia, NW Colombia (23 genera, over 100 species, especially Vaccinieae). Luteyn attributed this to 'adaptive radiation' in the very wet climate there, but did not refer to the regional geological history of terranes accreted from the Pacific side. In fact, a similar pattern occurs in pantropical marine groups, such as fiddler crabs (Uca), which have maximum diversity around the coasts of NW Colombia (Crane 1975). This pattern and its occurrence in both marine and alpine groups could easily be explained as the result of terrane accretion.

In Ericaceae there are several trans-Pacific tracks and it is not possible to understand the group in Malesia without considering these. There are southern connections in Gaultheria (several groups), central connections in Dimorphanthera - New World Vaccinium, V. sect. Macropelma, and possibly in the Gaultheria-Diplycosia-Tepuia clade, and northern Pacific connections in Rhododendron, Vaccinium, Gaultheria, and the Lyonia group.

Clethraceae, with about 64 species, is closely related to Ericaceae, as mentioned above, and is another typical Pacific group. It ranges in tropical Asia (SE China and Japan through Malesia to New Guinea) and mainly tropical America (SE US to Brazil), with one species in Madeira (Sleumer 1971b).

The pantropical Casearia and its relatives comprise the sister group to Flacourtiaceae s.s./Salicaceae (Savolainen et al. 2001). Casearia pachyphylla Gilg of NE New Guinea (mossy mountain forest in the Schrader Mts. and Saruwaged Mts.) is unique among the 60 Malesian Casearias by its peduncled inflorescence, a character otherwise known only in some Brazilian species (Sleumer 1954).

Van Steenis (1962a) cited and mapped many trans-Pacific plant groups. The following are some other, recently-studied examples.

Citronella D.Don (Icacin.) is in Malesia, E Australia, SW Pacific islands, and South America. Old World and New World species have been placed in separate sections, but Sleumer (1971) found that the characters used to discriminate the two are rather vague or do not hold.

Deplanchea Vieill. (Bignon.) has affinities with American plants (van Steenis 1977).

Castanopsis Spach and Lithocarpus Blume (Fagaceae), dominant in many Malesian forests, have virtually identical distributions: SE Asia/Malesia - NW United States (Soepadmo 1972). Mitrastema Makino (Rafflesiaceae) is parasitic on these and other Fagaceae such as Quercus, but ranges only from NE India to Japan and New Guinea, and in S Mexico (Chiapas)/Guatemala and NW Colombia (Antioquia) (Meijer and Veldkamp 1993).

In Solanum L., Symon (1986) cited direct links between New Guinea and central America species in each of sections Cypellocalyx Bitter, Lasiocarpa (Dunal) D'Arcy, Micrantha Dunal and Torva Nees.

The tribe Schismattoglossideae of Araceae ranges between China and Vanuatu, with a centre on Borneo, but also has three species in the Neotropics (Hay 1996). 
Oreomyrrhis andicola (Kunth) Hook. s.l. (Umbelliferae) is recorded from Kinabalu, New Guinea, and is widespread in the Andes (Dransfield 1987).

The tribe Moutabeeae of Polygalaceae comprises Eriandra Royen \& Steen. of New Guinea and Solomon Islands, Balgoya Morat \& Meijden from New Caledonia, and three genera of tropical South America (van Royen and van Steenis 1952, van der Meijden 1988, Balgooy and van der Meijden 1993). Although Eriksen (1993a) indicated that the tribe Moutabeeae is polyphyletic, he and van der Meijden (1988) both accepted that the sister of Eriandra is Diclidanthera Mart., one of the American genera. Eriksen (1993b) accepted the Moutabeeae as previously defined and had it as sister to Xanthophyllum Roxb., diverse throughout Malesia.

Spondias L. (Anacard.) has 10 species occurring naturally in the Indo-Malesian and American tropics (four species are widely cultivated through the tropics) (Ding Hou 1978).

In legumes (Verdcourt 1979), Oxyrhynchus Brandgee (Papilionoideae) (incl. Peekelia Harms) has one species in Papuasia, and three or four from Texas to Colombia and the West Indies. Inocarpus J.R. \& G.Forst. (Caesalpinioideae) (Malesia, Pacific Islands) and Etaballia Benth. (Brazil, Venezuela, Guyana) are either congeneric or closely related.

Discussing Kinabalu ferns, Holttum (1964) mapped taxa restricted to both sides of the tropical Pacific (Gleichenia subg. Diplopterygium Diels and Cibotium Kaulf.), and both sides of the tropical and South Pacific (Schizaea fistulosa, Paesia A. St-Hil., Dicksonia L'Hérit. (also one species in St Helena), and Culcita Presl. (also one species in Portugal-Azores)).

Pacific basin distributions are also well-known in animals (higher order groups include the millipede superfamily Conotyloidea (comprising 9-10 families) (Eskov and Golovatch 1986), and trans-tropical Pacific distributions even occur repeatedly within taxa such as the ponerine ants (Lattke, in press).

Amphi-Pacific distributions are probably related to distributions restricted to the Central Pacific, like that of Campanulaceae subtribe Sclerothecinae: Hawaii, Tahiti, Cook Islands (Raynal 1976), or the palm Pritchardia Seem. \& H.Wendl.: Hawaii, Tuamotus and Fiji (Corner 1966).

Sommieria Becc. (New Guinea), Pelagodoxa Becc. (Marquesas) and Manicaria Gaertn. (tropical America, West Indies) form a group of related palms (Corner, 1966).

Vaccinium sect. Macropelma Klotzsch is endemic to Hawaii and SE Polynesia (Marquesas, Society, Rapa, and Cook Islands). It occurs in what Vander Kloet (1996) called two 'disparate' island groups, but the Hawaiian and SE Polynesian islands are probably not really disparate - that is, 'essentially different, ... incommensurable, without comparison or relation, ... so unlike that there is no basis for their comparison' (Oxford English Dictionary). In a brief panbiogeographic analysis (Heads 1983) Hawaii and Marquesas were shown to be connected by a standard track. Sleumer (1941) related V. sect. Macropelma to sect. Myrtillus (greatest diversity along the Pacific rim from Japan to Mexico (Vander Kloet 1996)) and this is confirmed by analyses of DNA (Kron in press).

West of Vaccinium sect. Macropelma, Vaccinium species on Vanuatu (one is indicated in Oarianthe III; Fig. 49) are related to Malesian plants. In Fiji, between Vanuatu and the central Pacific Macropelma, there is no Vaccinium and the only Ericaceae is Paphia (shared with Queensland, New Caledonia and New Guinea). Across the plate margin in Samoa, $V$. whitmeei is of 'unknown sectional affinity'.

Unlike many authors who have denied that there is a true Polynesian flora, Philipson (1970) argued that plants such as Meryta J.R. \& G.Forst., Tetraplasandra A.Gray (both Araliaceae), Fitchia Hook.f. (Compositae), Sclerotheca A.DC., Vaccinium sect. 
Macropelma, 25 endemic species on Rarotonga, and many others indicate that the southern Pacific islands must be credited with a flora specific to this region ... Clearly land has been present for long periods in this area of the Pacific because well-marked genera are endemic to it. The flora characteristic of this region could survive provided a few oceanic volcanoes projected above the sea at all times. Such oceanic islands characteristically rise and fall relative to sea-level so that they are precarious footholds for a flora, but collectively they form a secure base'. In this view, vicariants could also maintain their respective ranges in adjacent archipelagoes, as long as new volcanoes and atolls constantly appear to replace vanishing ones. New individual islands will be colonised by ordinary, everyday movement, an observable ecological phenomenon which functions using ordinary means of survival.

This is a very different process from the (imaginary) biogeographic dispersal which relies on theoretical jumps, freak events, extraordinary and mysterious 'means of dispersal', epic voyages by waifs and strays, etc., to explain standard patterns. Not surprisingly, even its adherents often admit that this process can be rather mysterious, especially in taxa with limited means of dispersal. Conversely, the albatrosses range at ease over thousands of kilometres of open ocean but always return to very specific localities to breed (e.g. on mainland New Zealand only at Dunedin) and these are vicariant with their relatives' breeding localities in standard biogeographic patterns.

Ideas on the survival of flora discussed by Philipson find parallels in zoological work. For example, 'It is virtually universally accepted now that the Polynesian Islands have been populated by overseas dispersal in quite recent times ... Yet the highly endemic and antique nature of the Pacific Island snail fauna ... cannot be dismissed' (Solem 1976).

Discussing the Fiji lizard fauna and criticising the usual interpretation of their derivation by long distance dispersal, Zug (1991) wrote that 'The persistence of ancient taxa and their speciation on different island groups indicate the continual presence of emergent islands throughout the long history of Indoaustralian-Pacific plate interactions.'

\section{Shoot architecture and habit}

The main topic of this paper involves the evolution of Ericaceae in space, time and form. Evolution of form in biology is usually interpreted teleologically in terms of 'purpose' - a structure is seen to have evolved 'in order to' achieve a certain end. In this paper, however, particular morphologies are instead interpreted as the results of morphogenetic trends which are primarily structural and due to processes such as molecular drive (Craw et al. 1999). In this view, any particular adaptation is a secondary aspect of a main trend, a single point on a series or trajectory of morphologies as seen, for example, in the many species of a large genus. Of course, any observed morphology must have attained a certain level of viability or it would not occur. The morphogenetic trends (the antithesis of random mutation) take place largely independently of the environment and may eventually lead to subviable morphologies and extinction. Thus the trends (Darwin's 'laws of growth' (Grehan and Ainsworth 1985)) are of primary importance, and supply the raw material on which natural selection can bring about secondary 'pruning'.

Morphological structure, like biogeography, is usually interpreted as beginning from a restricted centre of origin, for example a leaf, gland or scale beginning as a small 'outgrowth' and developing by 'selection pressure' into a large, more complex structure. Instead, organs in Ericaceae are interpreted here mainly as the results of prior trends in suppression, reduction and fusion of parts. 
For example, the angiospermous flower may be the result of reduction of a complex strobilar structure involving the 'telescoping' of parts. If this reduction has been even with respect to the different radial sectors, a regular flower results. If the process has been uneven, zygomorphy, often cryptic, is produced. Both states are alternatives, neither more 'advanced' than the other, derived from a more complex ancestral prefloral condition. It is not a question of a zygomorphic flower being 'derived' from a radial flower. Ericoids and rhododendroids differ in floral morphology, notably in the obvious zygomorphy of many Rhododendron species. However, flowers of 'Grisebachia' and 'Acrostemon' (both now Erica s.l.) can be slightly oblique (Brown 1905). In other Erica spp. ('Philippia') a bract is more or less recaulescent with the pedicel. In some species the bract becomes totally recaulescent and forms part of the calyx as the apparent abaxial sepal, the sepal itself disappearing (Oliver 1991). Below the flower the 'pedicel + bract base' is a compound structure of fused stem and leaf, a hypoclade (Bugnon 1955). Pichi Sermolli and Heiniger (1952) illustrated the dimorphic P. abyssinica which has both zygomorphic and actinomorphic flowers. The 'false' zygomorphy (Oliver 1989, 1991) in 'Philippia' can be contrasted with 'real' zygomorphy in Rhododendroideae etc., but a similar telescoping process in the origin of the flower may also be responsible for the zygomorphy in these plants.

\section{Ericoid shrubs as largely sterilised inflorescences}

Rhododendron and Erica have very different shoot architecture. Rhododendroideae have inflorescences usually terminating the main branches, while in Ericoideae inflorescences may apparently terminate the main branches but in reality are 'intercalary' and always include a vegetative bud (Cullen 1978). Philipson (1966) interpreted the apex as periodically vegetative and reproductive. In other 'ericoid' plants (e.g. Kelleria, Thymelaeaceae) different species in the same genus can show intercalary or terminal inflorescences (Heads 1990).

In addition to inflorescence position, there are other important architectural distinctions between Erica and Rhododendron. Rhododendron has dimorphic foliage of large foliage leaves, and much smaller bud scales (perulae) with open venation. For example, the perulae of R. javanicum differ in colour, size, shape, texture and venation from the foliage leaves. They resemble epacrid foliage, as do the bracts of other Rhododendron and Vaccinium species (Fig. 4). In contrast to Rhododendron and its dimorphic foliage, ericoid shrubs (incl. ericoids, epacrids, 'Empetraceae', Monotropoideae s.s.) have only one kind of foliage: the vegetative leaves are similar, often very similar, to the floral bracts and both are bract-like.

A possible explanation is that the whole plant in ericoid shrubs is equivalent to an inflorescence of Rhododendron (itself highly telescoped) or, more obviously, Vaccinium - the newly expanding inflorescences of many New Guinea Vaccinium species closely resemble vegetative shoots of epacrids.

In the ericoid 'bract-plants' there is (a) a 'reduction' of the plant to just an inflorescence, and (b) a sterilisation of most of the bracts with flowering restricted to the end of the shoots/sterilised peduncles (or basally on the branches as in Acrotriche ramiflora R.Br. and relatives (Paterson 1960)).

Oliver (1991) recorded an interesting 'limit case' in Calluna, half-way between a 'bract plant' and a 'normal' plant with dimorphic foliage. The inflorescence was described by Webb (1972) as a terminal or intercalary raceme or panicle, but by Stevens (1970) as axillary and usually single-flowered (cf. Gaultheria spp.). 


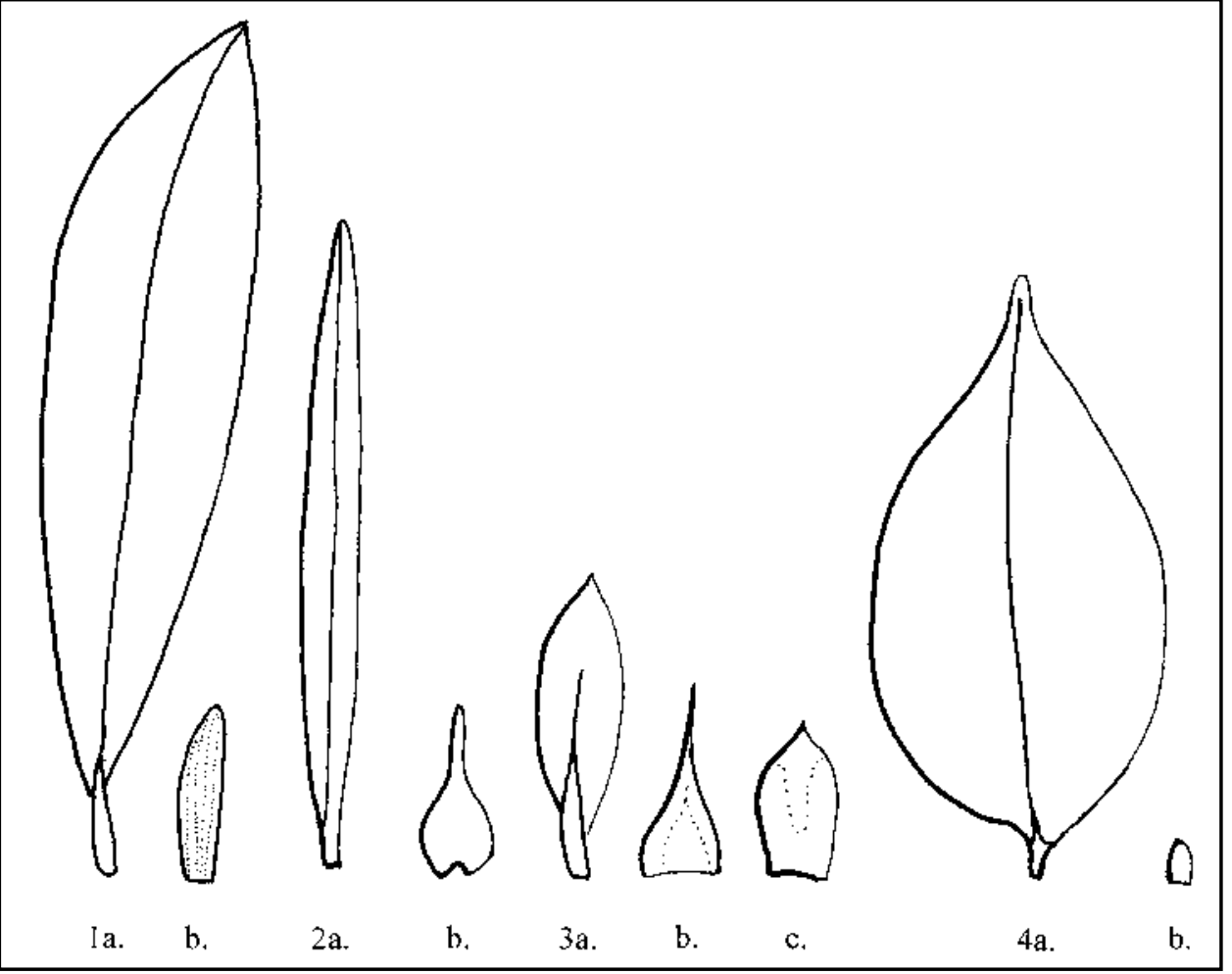

Fig. 4. Leaves (a) and perulae (b) in 1. Rhododendron javanicum (van Steenis 1962), 2. R. caliginis (Kores 1984), 3. R. capellae (Kores 1978) (b. outer perula, c. inner perula) and 4. Vaccinium cf. albicans (Heads s.n.).

Epacrids are largely 'bract plants', while their sister group, the Vaccinioideae, have dimorphic foliage. Both groups are recorded from both Africa and the Pacific, and so seem to contradict the trend in ericoids/rhododendroids, in which bract-plants are in the west, and their normal, dimorphic-foliage relatives in the east. However, epacrids are recorded from SW southern Africa (fossil) whereas Vaccinium only reaches the Transvaal, and in the central Pacific the Vaccinioideae have a greater massing than the epacrids, and at least some of the epacrids here (e.g. on New Caledonia, see below) are dimorphic.

In Monotropoideae s.s. the scale-like leaves and their bracts are more or less identical, whereas foliage in their relatives, Pyroloideae and Arbutoideae is normal and dimorphic.

Other 'bract-plants' are found in New Zealand, northern Australia (described next), South and East Africa and Madagascar. North and east of New Zealand and New Caledonia there are notably very few on the Pacific islands (from New Guinea and Chatham Islands east).

In Dracophyllum Labill. (epacrids), the species with racemes or panicles have distinct bracts, and these are most highly differentiated from the leaves in the tree species (Oliver 1928), especially in the massive New Caledonian D. involucratum Brongn. \& Gris. comprising subgen. Cordophyllum W.R.B. Oliver. Here the inflorescence is a $40 \mathrm{~cm}$ long 
spike, with flowers borne in dense fascicles each on a separate pedicel/peduncle covered with numerous bracts. The opposite morphological extreme is shown by the prostrate mats and cushions of subgen. Oreothamnus (F.v.Muell.) Oliver with terminal, solitary flowers, especially D. muscoides Hook.f. (southern South Island New Zealand) and D. minimum F.Muell. (Tasmania). In these dense, hard 'cushion plants' only a few centimetres in diameter, the leaves are very small (2-3 $\mathrm{mm}$ long in $D$. muscoides) and the bracts are very similar. As Oliver (1928) perceived: 'Each flowering peduncle [in Cordophyllum] might be compared with a separate branch of such a species as $D$. minimum'.

Pachynema DC. (Dilleniaceae) comprises xerophytic, broom-like shrubs of northern Australia and is usually affiliated with Hibbertia Andr. Beyond the seedling or coppice stage the often flattened stems are leafless but bear bracts. Some species have rhizomes, which occur elsewhere in the family only in Acrotrema Jack (Sri Lanka, southern India, Burma and Peninsular Malaysia).

Craven and Dunlop (1992) observed that: 'Unlike the other genera of Dilleniaceae, Pachynema rarely exhibits a distinct vegetative phase followed by a distinct flowering phase or inflorescence ... The presence of basal, functional leaves in three species ... suggests to us that perhaps the bracts on the aerial stems may not represent reduced leaves on a vegetative stem but may be equivalent to the inflorescence bracts described for other genera, e.g. Dillenia (Corner 1978b)'. The aerial stems (above the short leafy section if present) are interpreted by Craven and Dunlop 'as elaborate inflorescences which have been modified into largely non-flowering, 'vegetative' stems'. The morphogenetic relationship between Dillenia and Pachynema is the same as that between the large- and small-leaved taxa of Dracophyllum compared by Oliver (1928).

The branches of Ginalloa Korth. and Notothixos Oliv. (Visc.) bear both normally developed leaves and rudimentary cataphyll-like ones, often in successive pairs, but in Ginalloa the pattern is more variable, and some species bear very few normal leaves (e.g. G. nuda Danser, a Kinabalu endemic) (Barlow 1997). Inflorescence bracts in these plants are small and arranged in pairs forming a boat-liked cupule (like the rudimentary leaves), and these bract-plants may have a similar origin to those already cited.

Three lepidocaryoid palms have flagelliform inflorescences which can develop as individual plants. The inflorescences are up to $2 \mathrm{~m}$ long and the ultimate branches lie on the surface of the soil (Dransfield 1978) where they take root and grow a new shoot. This eventually becomes established as a separate plant.

In the Hebe complex (Scrophulariaceae), Bentham (1846) compared the habit of the ericoid, whipcord hebes with that of Andromeda and Cassiope species. The ericoid hebes (Leonohebe Heads) have been interpreted as the equivalent of sterilised inflorescences of the large-leaved, orthotropic Hebe (Heads 1994a). The ericoid Olearia sect. Divaricaster Heads (Compositae) and the small-leaved Coprosma J.R. \& G.Forst. (Rub.) species also differ from their large-leaved relatives in similar ways: plagiotropy, determinate long shoot axes, and differentiation of brachyblasts. They have been interpreted in the same way as the plants in the Hebe complex (Heads 1996, 1998).

Frankeniaceae and Tamaricaceae are sister families in the otherwise mainly insectivorous clade which is sister to Centrospermae (Savolainen et al. 2000). They are both heath-like shrubs centred in Africa and Eurasia (they are absent in Malesia) and favour sandy or salty places, both maritime and inland. Frankenia L. has leaves with inrolled margins like Erica and bracts which are no different from the leaves. Tamarix L. also has scale-like leaves and bracts but in addition has more mesophyllous 'juvenile' foliage like that of Leonohebe and certain Cupressaceae (Heads 1994a). 
Summing up, dwarf shrubs, whether coastal or alpine, are often not simply miniature trees. Their whole morphology is different and closely related plants such as Erica and Rhododendron can have quite different architecture, leaf and bract morphology, and 'inflorescence structure. Perhaps it is simpler for the plant to change into an 'inflorescence-' or 'bract-plant' than for the whole plant to be miniaturised.

It may be relatively simple morphogenetically to suppress the large-leaved part of a shoot, leaving only the inflorescence, possibly with a few residual ('juvenile') leaves basally. It may also be relatively simple to sterilise a large part of this 'inflorescenceplant', leaving only the scales over most of it and restricting flowers to (usually) branch tips. The result is a microphyllous, xerophytic shrub with all the ecological adaptability of this life form, and able to survive in many extreme environments.

There is abundant other evidence from the Ericales suggesting evolution of architecture by the suppression and sterilisation of parts. For example, everyone agrees that the typical umbelliform Rhododendron inflorescence is a condensed structure, evolved from an earlier racemose arrangement as seen in many Vaccinioideae. The 'telescoping' in the flower of Erica ('Philippia') was mentioned above. In some epacrids Watson (1964) pointed out that at least the distal bracts are aborted inflorescences, recalling epiphyllous inflorescences in Chisocheton Bl. (Melia.), Flacourtiaceae tribe Phyllobotryeae and others. Oliver (1991) also recorded clear evidence for reduction and fusion in floral parts in Erica, especially in the former minor Cape genera.

The different forms of scales and hairs on the leaves of Rhododendron seem to characterise large geographic and phylogenetic groups, but their history in the evolution of the leaf is unknown. These structures and others, such as the glands at the base of the lamina in Vaccinium and Dimorphanthera species, and the laticiferous system in Roridula, may not be superficial, secondary features, added on to an otherwise fully-evolved leaf or shoot, but rather relictual traces of prior, largely suppressed morphology and physiology. This agrees with Schwendt's (1907) important general concept of a gland as a region of hemmed-in growth.

* Malesian Ericaceae include the whole sequence from densely branched cushions (148: Rhododendron saxifragoides) and prostrate mats to decumbent shrubs, scandent shrubs/lianas (Dimorphanthera, 3: Vaccinium fissiflorum Sleum., etc.), and erect shrubs and trees (D. pulchra J.J.Sm. is a small tree up to $15 \mathrm{~m}$ high in primary forest). Species cited as 'hemi-epiphytes' (Sleumer 1967: Fig. 115) begin life as epiphytes, but by sending roots down the host tree may reach the soil and become terrestrial as lianes.

A number of Ericaceae species may be erect shrubs, trailing shrubs, or vines, depending on the habitat. All of these may be epiphytic or terrestrial. In 'moss forest' (often there are more liverworts) the plants often grow on more or less dead, halffallen tree-trunks, and here the distinction between epiphytic and terrestrial wears thin. Authors like Parris (1983) distinguish three main habitats for plants in these forests, rather than two: epiphytic, terrestrial and rupestral. The distinctions between these mainly involve light and drainage.

In Ericaceae, Hallé et al. (1978, citing Temple 1975), recognised the architectural models of Holttum (Dracophyllum), Leeuwenberg (Dracophyllum, Erica, Rhododendron, Pieris), Scarrone (Arbutus, Rhododendron), Rauh (Styphelia, Erica, Calluna), Mangenot (Vaccinium), and Troll (Leucothoe). A liane species of Pieris had no known model. Numerous southern African Ericoideae species examined in the wild proved difficult to assign clearly to any known models (A.Temple pers. comm., cited in Oliver 1991).

\footnotetext{
* Species numbers given here follow Sleumer's Flora Malesiana treatments and are cited to allow easy reference to the large genera in Sleumer's work and to the maps below.
} 
Stevens (1981) observed that many, if not all, Rhododendron species and also Gaultheria pullei have architecture conforming to Leeuwenberg's model. Scarrone's model differs from this only in its monopodial trunk and is common in Ericaceae, and intermediates between the two models occur. Many other New Guinea Ericaceae are similar but also show abortion of the shoot apex. Sleumer (1967) illustrated this in Diplycosia pinifolia and Vaccinium leptospermoides, and it also occurs in Gaultheria, Dimorphanthera and Agapetes (Stevens 1981). The lianoid species (?Champagnat's model) also have determinate shoot apices. Vaccinioideae in general tend to share abortion of the apical buds of the vegetative shoots (Kron, Fuller et al 1999) and Rhododendron axes are determinate by flowering.

In Rhododendron, Asian species vary from trees up to $20 \mathrm{~m}$ tall with a trunk $60 \mathrm{~cm}$ diameter (Noshiro and Suzuki 2001) to small shrubs 5-10 cm tall. In Malesia plants are usually 1-2 m high shrubs, sometimes small trees up to $12 \mathrm{~m}$ tall (e.g. sp. 249: 1-12 m New Guinea; sp. 251: 6-15 m Kinabalu; sp. 278: 3-12 m Malesia). Many species grow to $6 \mathrm{~m}$ tall. Species 23 is a 'small crumpled tree' with a trunk c. $35 \mathrm{~cm}$ d.b.h. Sp. 225 has a 'writhed' trunk, as seen in Asian species and recalling liane stems.

In the models of Leeuwenberg, Scarrone and Rauh all axes are orthotropic. However, plagiotropy is evident in Ericaceae with spreading and decurved branches (e.g. Vaccinium varingiaefolium), and is widespread in epacrids such as the mat species of Dracophyllum. Plagiotropy is absent in many Rhododendron, but present in the dwarf, spreading forms, which are epiphytic (140: R. caespitosum, forming $10 \mathrm{~cm}$ high cushions on tree fern trunks in alpine grassland, branches rooting), sprawl over rocks (139: R. gracilentum), or are cushion plants in alpine peat-bogs (148: R. saxifragoides). In Malesia, smaller Rhododendron species include dwarf shrublets of the Latimodjong Range (33), Mt. Kinabalu (19), and Irian Jaya (102) which may be decumbent $(142,147$, $152,153)$. Other smaller species also show marked plagiotropy: sp. 5 is a $5 \mathrm{~cm}$ to $1 \mathrm{~m}$ tall xerophytic shrub, prostrate on limestone at Wilhelmina, 139, 10-60 cm, is subprostrate and also recorded from limestone and other prostrate or creeping species include: 8, 53 (on limestone), 137 (5-10 cm high).

The presence of rhizomes, an aspect of plagiotropy, is an important polyphyletic trend in the Ericaceae. In Malesian species rhizomes occur in Rhododendron ( $R$. anagalliflorum), Pyrola, Gaultheria, Vaccinium, Agapetes, and Diplycosia (mostly in open, high altitude grasslands) (Stevens 1981). In Erica there are also prostrate marsh forms with rhizomes (Oliver 1991).

How can the presence of both orthotropy and plagiotropy in the same lineage be rationalised morphogenetically? Many plants, for example palms, whose stems are otherwise purely orthotropic show striking plagiotropy in their inflorescences, and plagiotropy may be another feature inherited by bract-plants (cf. plagiotropic axes in divaricate Coprosma, Heads 1996).

The smallest Erica, E. petrophila L.Bolus (SW Cape), is $100 \mathrm{~mm}$ tall and covers only $400 \mathrm{~mm}$ in cracks on large boulders or rock faces. Other Erica species grow on damp rock ledges and form moss-like matted plants (E. physophylla Benth., E. ophylla Benth.) (Oliver 1991). Plagiotropy is often associated with limestone, and the plagiotropy may have been inherited from mangrove-associate ancestors.

Another aspect of plagiotropy is seen in the 34 Rhododendron species described by Sleumer as having 'divaricate' branches. Other Rhododendron species have more or less sprawling or scandent divaricate branches (46, 51, 79, 109, 135, 136, 138, 255). 'Corymbose' architecture is seen in the flat-topped shrubs of 165 (Sleumer 1966: Fig. 35) and Gaultheria 11 (Sleumer 1967: Fig. 64). 
'Divaricate shrubs' is a term used universally in New Zealand for plants with a very specific architecture in which brachyblasts are differentiated and apex abortion occurs in the long shoots, giving 'cymose' architecture (e.g. Olearia sect. Divaricaster (Compositae) (Heads 1998a), many Coprosma spp. (Rubia.) (Heads 1996)). Plants with this syndrome are 'bract-plants' (above), and are especially abundant in southern and east Africa and Madagascar. As noted above, many Malesian taxa have the shoot-tip abortion which is always present in the New Zealand-African 'divaricates'. Unlike these plants, however, Malesian Ericaceae show no sign of brachyblast differentiation. Some South African ericas do show differentiation of brachyblasts (e.g. E. ribisaria Guthrie and Bolus) and in general the New Zealand-African 'divaricate' plants and ericoids are 'bract-plants' (see above/below) like Ericoideae, unlike most Rhododendroideae, despite their divaricate branching.

The root system of Malesian Ericaceae, particularly in crater fields and near solfataras, is very horizontal, and roots may attain large dimensions in such places. This is of course common to all plants growing on sterile, rocky, impervious or badly drained soils. Such roots also have a distinctly corky bark (Sleumer 1966).

\section{The hypocotyl and lignotuber}

Swollen stem-bases and adjacent roots, developed from the hypocotyl and capable of storing water and resprouting occur in many Ericaceae. Describing the California chaparral, where resprouting species of Arctostaphylos Adans. are important, Wells (1969) noted that the habit is generally regarded as a specialised trait, evolved in response to fire as a selecting agent. However, he concluded that 'The truth of the matter is that the capacity to sprout vegetatively from older wood, stumps, or underground parts following destruction of the tops by fire is a widespread and probably ancestral trait among angiosperms.' In Malesia crown-resprouting is important, especially in epiphytic species of Vaccinium and the related genera Agapetes, Costera and Dimorphanthera. Thickened roots occur in Rhododendron, e.g. 52 (Sleumer 1966: Fig. 12), 152, 168, 205. The thickening often 'superficially resembles a lignotuber' (Sleumer 1966) with several stems arising from it and heathland species in general often have lignotubers (Specht and Womersley 1979). Lignotubers, root-crowns, or burls are enlarged, bulbous structures formed by the root-shoot 'interface tissue', and equivalent to xylopodia (Brazil), souches (France), and toucas (Portugal). These are well-known in Erica arborea as they are used for making pipes, and Rhododendron or Kalmia burls in North America can weigh more than $200 \mathrm{~kg}$. Malesian species like Vaccinium varingiaefolium and $V$. striicaule in particular persist after fire because shoots develop from the root crown. Sleumer $(1967$ Figs. 72, 75, 99) illustrated Diplycosia cf. kinabaluensis (from temporarily inundated rocks), Diplycosia 65, and Vaccinium 114 with a swollen hypocotylar bases and thickened roots.

In the Ericoideae the vast majority of species regenerate only from seed after a veld fire - fewer than $10 \%$ of Erica species in the Cape Floristic region resprout from a lignotuber, although this is common among Euro-Mediterranean species (Ojeda 1998). Ericaceae species in Malesia also have igneous and pioneer ecology, but there are no comparable figures for resprouting species vs. seed reproducers. In the Cape, the highest number of resprouters occurs in the eastern Cape, while the lowest is in the SW Cape. Lignotubers occur in the widest ranging South African Erica (E. cerinthoides L.) and a very few others. The few that resprout do so at ground level from 'swollen stem bases or root stocks referred to as burls or lignotubers ... In the Cape species this lignotuber may reach up to $100 \mathrm{~mm}$ in diameter for plants only $150 \mathrm{~mm}$ tall. In the very variable $E$. coccinea most forms only regenerate from seed, but the form occurring on the limestone flats near Agulhas is a resprouter ...' (Oliver 1991). Erica trichostigma Salter, of sandveld, 'produces a number of stems from a common root underground' (Schumann et al. 1992). 
The hypocotyl is morphologically intermediate in structure as well as position between shoot and root. However, in addition to the well-known variation giving rise to epigeal and hypogeal germination it develops in many ways and may represent something more than simply a transition zone.

In a typical 'pan-adaptationist' view (the dominant paradigm at least in the Anglophone countries) it has been argued that the purpose of lignotubers in neotropical Ericaceae appears to be for the production of buds ...' (Luteyn 2002). However, plant structure is not accepted here as having evolved because it has a 'purpose'. Rather, a particular series of biological structures, with some 'adaptive' and some 'neutral,' is the result of prior structural trends. Luteyn (2002) also suggested that lignotubers 'probably also provide an advantage to new seedlings', but any 'advantage' is interpreted here strictly as a secondary consequence of the primary morphogenetic trend.

The main trends in hypocotyl morphology which may have led to the ericaceous hypocotyl/lignotuber and the consequent ecology, can be indicated with a summary of variation in the hypocotyl of the angiosperms.

The hypocotyl takes many different forms. In African Caesalpinioideae the following variations occur in the seedling at germination (Léonard 1957):

- the hypocotyl may lengthen or not;

- the stem/root axis may be central or lateral to the cotyledons;

- the collet or collar at the hypocotyl/root junction may or may not bear an 'appendix' - a ring-shaped lateral spur.

The different combinations of these three features characterise the different genera. Léonard (1957) also emphasised the importance of the hypocotyl in other plants, such as in Hura L. and Dichostemma Pierre (Euphorbiaceae) in which it grows to $20 \mathrm{~cm}$ long while the cotyledons remain in the testa, as in mangroves.

The hypocotyl in subtribe Myrtinae (Myrtaceae) may be greatly swollen, rendering interpretations of embryo morphology in these plants controversial (Landrum and Stevenson 1986). At the lower end of the hypocotyls, ring-shaped protuberances, often bearing absorbing hairs, occur in Myrtus L., Leptospermum J.R.\& G.Forst., Melaleuca L., Callistemon R.Br., and Angophora Cav., and these even take the form of bizarre 'coleorrhizae' enclosing the radicle in Eucalyptus L'Hérit. (Baranov et al. 1955, Baranov 1957). Baranov cited the last as 'the full expression' of the trend, but even this may be a largely reduced relic. Baranov cited a similar expanding hypocotyl base in the mangrove Bruguiera Lam. (Rhizophoraceae).

Caesalpinioideae, at least co-dominant in most woodlands and forests of Africa, and the mallee Eucalyptus species, dominant in many parts of Australia, are characterised by lignotubers that begin to develop at the seedling stage. In Eucalyptus these usually develop at the top of the hypocotyl in the cotyledonary axils, as in Quercus (Molinas and Verdaguer 1993a,b), but they may also develop from the hypocotyl below the cotyledons (Kerr 1925). The varied forms of xylopodia developed by cerrados plants in South America are similarly effective in achieving drought resistance.

The trunk of the frankincense tree (Boswellia Colebr. spp., Burseriaceae) of northern Somalia, Yemen and Oman has a basal swelling which often, especially in rockinhabiting plants, forms a \pm disc-shaped plate up to $70-80(-100) \mathrm{cm}$ in diameter (Thulin and Warfa 1987). This develops at a very early age and is initially almost entirely confined to the hypocotyledonary region.

The many other possible outcomes of hypocotyl development include the following. 
The viviparous axis of the mangrove seedling is well-known for its precocious development and is generally interpreted as hypocotyl, although in these plants it grows geotropically.

In the aquatic family Podostemonaceae Schnell (1970) wrote that there is no true root, instead haptera and rhizoids develop from the hypocotyl.

In Madagascan Hydrostachyaceae, also aquatics, studies of seed germination showed an important development of the hypocotyl as 'a sort of rhizome' (Koechlin 1967).

The seedling of Streptocarpus has a hypocotyl which ends at the base in an enlarged disc. This produces a crown of rhizoids (Rhizoidenkranz) before eventually elongating to form a central root (Schenk 1942).

The seedling of Elatine hexandra (Elatin.), a plant of periodically submerged mud, develops a ring of 'prop-hairs' or 'prop-roots' to form a skirt-like flange at the base of the hypocotyl (Salisbury 1967).

In Phylloxylon Baill. of Madagascar (Papilionoideae) the cotyledons are fused, and this involves the disappearance of the apical meristem; growth takes place instead from adventitious buds on the hypocotyl axis (Peltier 1970).

In Cucurbita pepo L., the marrow, the withdrawal of the cotyledons from the seed is aided by the development of a 'lateral outgrowth or peg' fom the lower surface of the hypocotyl (Purseglove 1988). A similar 'talon' occurs in other Cucurbitaceae as well as in Mirabilis L. (Nyctaginaceae). Likewise, in Scabiosa L. (Dipsac.) a 'thickened, projecting ledge' at the base of the hypocotyl pins the involucel to the ground at germination (Lubbock 1907).

In Marah Kellogg (Cucurbit.) the cotyledon petioles emerge from the seed fused into a single tube which bears apparently functional absorbing hairs on its outer epidermis. This tube flares out at the base into a 'flange-like cap' (Hill 1916).

In Hippuris L. (Hippurid.) 'there is considerable divergence of opinion as to the meaning and function of the ring of hairs produced at the collet.' (Good 1924).

A swollen zone in the hypocotyl and other 'geophilous features' occur at the root/shoot collet in Sapotaceae (Smith 1909).

In Linaria Mill. (Scroph.) the hypocotyl proliferates by means of buds which eventually grow stronger than the primary stem. The seedling can still grow by this means even if the top of the hypocotyl and the cotyledons are removed after germination (Lubbock 1892). Likewise, in the South African Galopina Thunb. (Rub.) innovation shoots develop from accessory cotyledonary and hypocotyledonary buds (Puff 1986). At first these grow plagiotropically underground, later they become ascending.

In the rainforest trees Garcinia, Barringtonia and Anisophyllea both cotyledons and endosperm remain undeveloped, the storage function being undertaken by the hypocotyl alone ( $\mathrm{Ng}$ 1978).

In southern African Eriospermum (Eriospermaceae) the hypocotyl forms a globose or irregularly-shaped perennating tuber, sometimes bearing a proliferation of 'rhizomes' or 'stolons' (Perry 1994).

Hypocotyledonary tubers are also a feature of herbaceous Aristolochiaceae growing in seasonal climates (Huber 1993).

'Macropodous' embryos with a conspicuously swollen radicle or hypocotyl occur in several basal families of monocots (submerged aquatics in Alismatiflorae, and several Araceae) (Dahlgren and Clifford 1982). 
In the Loranthaceae Bhatnagar and Johri (1983) reported that there is no true radicle and the 'radicular end' represents the hypocotyledonary extension. This may bear a 'fringe of lateral processes including hair-like structures'. In Viscum (Santal.) (Sallé 1983) and Amyema (Loranth.) (Calder 1983), the swollen, glandular meristematic apex of the hypocotyl bends towards the host and when it touches flattens to form an adhesive 'attachment disc' or 'holdfast' (developing into the first haustorium; cf. Barlow 1997).

Hypocotyl variation can have a geographic basis: American material of Vigna vexillata (L.) Benth. (Legum.) has epigeal germination in which the hypocotyl elongates, while Old World material of the same species has hypogeal germination in which the hypocotyl does not elongate (Vanderborght 1989).

The epiphytic 'ant-plants' in Hydnophytum Jack, etc. (Rub.) have characteristic large, rooting, aerial tubers formed from the hypocotyl and often covered with spines, probably aborted rootlets (pers. obs.). Labyrinthine cavities in the tuber house the ants. For Schnell (1970) these bizarre plants are 'incontestably very evolved, the last word, the most perfected', but instead the tubers may be just another one of a range of alternative possibilities in hypocotyl development.

All these different phenomena are points in a series, quite different morphologies but aligned on a single morphogenetic trajectory. The different structures may enhance the ability to survive in different environments, whether aquatic, terrestrial, arid, epiphytic or parasitic. However, each particular morphological 'adaptation', whether the disc of frankincense, the holdfast of the Loranthaceae, the talon of Cucurbitaceae, the tuber of the ant-plants, the 'rhizoids' of the Hydrostachyaceae, or merely, as in most plants, a slightly thickened or coloured 'collet' at the hypocotyl base, is a secondary consequence of the underlying morphogenetic trend in hypocotyl development.

These particular morphologies have important ecological consequences, for example in woodlands of America, Africa and Australia, aquatic communities in southern Africa, and Ericaceae-Myrtaceae heath communities and epiphyte communities in Malesia. These are all occupied or dominated by 'hypocotyl plants' with lignotubers and/or thickened stem bases. Perhaps the thickening of the hypocotyl/lignotuber represents the last trace of what was a well-developed system of hypocotyledonary rhizoids and more elaborate organs formerly widespread in seed-plants.

\section{Ericaceae ecology}

Ericaceae are well-known as plants of cold, high places, where the soil is acid and infertile. Ericaceae have endotrophic mycorrhiza present in their root cortex which at least partly explains their ability to survive on soils poor in nutrients, especially nitrogen and phosphorus. The peculiar mucilaginous sheath which surrounds the root-tip in Ericaceae (Leiser 1968) may also be ecologically significant. Ericaceae are usually characteristic of well-drained rocky sites: Malesian Rhododendron occur in sandy and rocky sites, on moss-covered rocks, rocky ridge-crests, white acid sand, clay, open gravelly or clayey ground of old gold workings, sluiced areas, edges of precipices, exposed summits (e.g. 119, 123), crevices in granite (e.g. 19: granite fissures to the very top of Mount Kinabalu, 4096 m), and cliffs (e.g. 157: Vaccinium horizontale).

However, Ericaceae also occur in other habitats. Monotropideae s.s. are without chlorophyll and are totally saprophytic; and they are also mycorrhizal. They live on the forest floor in full shade. Other taxa occupy a wide range of sites: hot or cold, wellor poorly-drained, and in acid or basic soil. 
Malesian Ericaceae species are often gregarious terrestrially on steep slopes and ridge crests, volcanic terrain, glades and other sterile places in the mountains (Sleumer 1966). For example, on Mt. Kerinci above $3000 \mathrm{~m}$ there is a brushwood consisting largely of of Gleichenia, Vaccinium miquelii, Rhododendron retusum and Gaultheria leucocarpa. On volcanoes in Bengkulu $V$. miquelii can have a diameter up to $40 \mathrm{~cm}$. Sleumer $(1966,1967)$ described similar communities from Kinabalu, W Java $(R$. retusum, V. varingiaefolium) and New Guinea (R. brassii, $R$. inconspicuum, $R$. herzogii, $R$. christianae, V. dominans). Sleumer (1967) cited species of Vaccinium which may form pure stands or even vegetation-belts in the upper montane zone, and Archbold et al. (1942) illustrated the interior of closed subalpine Vaccinium forest at Lake Habbema.

Gardeners cultivate vireyas in conditions which recreate a tectonic setting of welldrained areas such as alluvial terraces around peaty swamp forest in regions of uplift and vulcanism, and a climate with high atmospheric moisture and free movement of air. Good drainage and a very open potting mix are essential. Materials such as tree fern fibre, pine bark, coarse river sand, and scoria all help to keep the mix open, while use of peat-moss and leaf-mould open the soil up and also help retain moisture. At Kew, vireyas are grown in an open mixture of two parts coarse peat and one part coarse sand or grit, to which some charcoal has been added (Halliday 2001).

Specht and Womersley (1979) wrote that Malesian Ericaceae s.l. occur in the following oligotrophic environments: 1 . Tree crowns, 2. Forest floor, 3. Breaks in the rainforest (tree fall gaps, landslides and man-made clearings) as pioneer plants, 4 . Above the timberline, in the alpine zone, and 5. Low altitude kerangas and padangs. These provide useful headings for further notes, as follows.

\section{Tree crowns}

Vascular epiphytes, especially shrubby epiphytes, are a distinguishing feature of rain forest (Richards 1952). Richards interpreted the structure and ecology of epiphytes (and most other rainforest plants) in terms of pre-adaptation. He argued that epiphytes' extraordinary specialisations 'may not be adaptations which have evolved by gradual modification in the habitat the plant now occupies' and cited rainforest Bromeliaceae inheriting absorbing hairs from arid-dwelling ancestors. Richards concluded that 'The plants from which the epiphytes arose were thus 'pre-adapted' and families without the required preadaptations, such as legumes with their heavy seeds, have simply not given rise to epiphytes.'

One of the key preadaptations of Malesian Ericaceae for life as epiphytes is the thickening of the hypocotyl, permitting water storage and resprouting.

One of the features of the Malesian Vireya rhododendrons that struck botanists when they were first described is that so many are epiphytic, growing high on forest tree limbs with mosses and orchids (Withers 1984). Sleumer (1966) recorded the following species from primary ('primaeval') forest, and these are mainly epiphytic: Rhododendron spp: 22, 23, 25 var. 11, 46, 73, 150, 154, 213, 223, and Vaccinium 221 ('virgin forest'). In the vaccinioids, Gaultheria is exclusively terrestrial while its close relative Diplycosia is predominantly epiphytic. Many species of Rhododendron will grow in either situation. All species found growing as epiphytes have been found growing as terrestrial plants, but a number of terrestrial species have never been found growing as epiphytes. Vireya rhododendrons grow as terrestrial plants in open habitat, but when growing in dense forests in competition with other trees they occur as epiphytes, as they require high light levels and tolerate rapid drainage.

At and above tree-line a 'heathland' high in the trees descends to the ground (Fig. 5), with associated plants such as ant-plants (Hydnophytineae, Rubiaceae); ant-plants are terrestrial only above the tree-line, and this only occurs in Irian Jaya (An exceptional 
new, undescribed species of Hydnophytum from Mt. Michael breaks both rules by being terrestrial in forest and in PNG (M. Jebb pers. comm.)).

In Nepenthes, 12 Malesian species are recorded from both epiphytic and terrestrial sites (Cheek and Jebb 2001), and of these sp. 46. is noted as terrestrial in thin woodland, 44. is terrestrial in swamp grassland, ridge tops, open forest on white

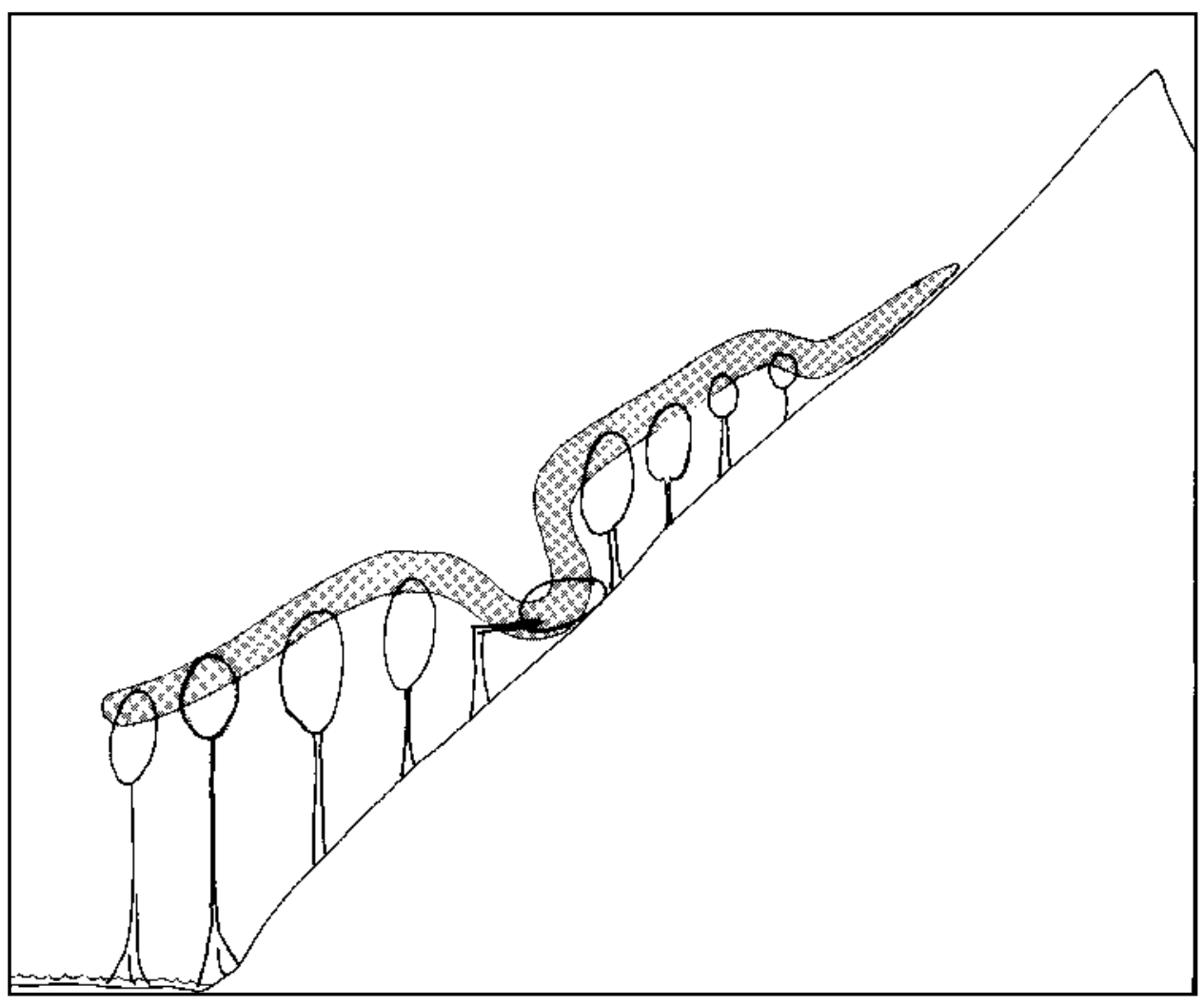

Fig. 5. Ecology and altitude in Ericaceae, ranging from epiphytic in mangrove to terrestrial in forest gaps and above tree-line.

sand, and ultramafic soils, and 38., the highest Nepenthes, is terrestrial in alpine scrub and grassland in Irian Jaya.

The habitat of epiphytes is similar to that of plants growing on rocks, and several species of Rhododendron occur as epiphytes and also terrestrially on rocks. Other epiphytic-terestrial transitions are seen in the following Rhododendron species:

9: generally epiphytic, but also terrestrial in swampy (i.e. open) shrub-covered places, or in alpine scrub.

37: epiphytic just below true moss forest, terrestrial on edge of cloud forest.

51: epiphytic in moss forest or on tree ferns in grassland, terrestrial in more open Nothofagus, Podocarpus, and Pandanus forest, along banks of creeks, edges of bogs, natural or artificial clearings, landslides, cliff faces.

54: high epiphyte in Castanopsis / Nothofagus forest, terrestrial in openings or grassy slopes. 
71. (R. truncicolum Sleum.): epiphytic on giant emergent trees of Araucaria cunninghamii, terrestrial in open vegetation on sandy, riverine flats and sharp ridges (Stevens 1981).

112 (cf. 115): epiphytic in rather dense forest, terrestrial in more or less open, devastated Nothofagus summit forest or scrub.

131: epiphytic in ridge forest, terrestrial in kerangas and elfin woodland,

176: epiphytic in moss forest, terrestrial in open places on moss cushions.

172: epiphytic in low forest, terrestrial in shrub vegetation.

139: epiphytic in Nothofagus forest, terrestrial on old gold workings.

250: epiphytic in primary forest, secondary forest and mangrove, terrestrial on rocks, in kerangas etc.

Diplycosia 92: is epiphytic in mossy low forest, terrestrial on open serpentine ridges.

In Vaccinium the following are all epiphytic, but terrestrial in the named habitats: 10 , 27: on limestone, 21: on boulders, 57, 58: on open ground with rocks, 73 : amongst grass in moist places, 132, 139: on rocks, 157: growing horizontally from eroded cliff face, and 204: at forest edges.

In Dimorphanthera (Stevens 1981), 28: at $850 \mathrm{~m}$ is epiphytic, at $1200 \mathrm{~m}$ is a high climbing liane in oak forest, and at $2150 \mathrm{~m}$ is a shrub in mossy forest/dense scrub.

D. amplifolia is epiphytic at lower altitude, terrestrial in subalpine forest on peaty soil.

Similar patterns of epiphytic/terrestrial habitat are seen in Grammitis (Parris 1983), in which otherwise epiphytic species are terrestrial on limestone, boulders in streams and (again, usually rupestral) in subalpine-alpine shrubland and grassland.

\section{Forest floor in closed forest}

This is an unusual environment for Ericaceae, but is occupied by the two saprophytic genera.

\section{Breaks and open places in forest}

Malesian Rhododendron species are recorded from low, light, or thin forest, Casuarina forest (sp. 92), degraded or devastated Nothofagus forest, ridge-crest forest, stunted/dwarf forest, dense subalpine forest, mossy forest (i.e. low and well-lit): dwarf mossy forest, light moss forest, moss cushions of old fallen trees, rotten stumps, open banks of streams in mossy forest, shrubby openings in forest, elfin woodland, and forest edge (Sleumer 1966, 1967).

\section{Above the timberline}

Several Rhododendron species occur on exposed rocky bluffs in open grassland (e.g. 96), in alpine grassland and in subalpine shrubland (e.g. 142). Rhododendron species are also recorded from other kinds of shrubland: low dense shrubland, scrub-forest, heath plains, and in open mossy thickets on exposed ridges,

\section{Low altitude kerangas and padangs}

Rhododendron spp. are recorded from low, scrubby kerangas vegetation on bare sandstone eroding into white sand ( 25 var. 9,131$)$. 


\section{Ericaceae as weeds of active margins}

In addition to the habitats listed above, Ericaceae are characteristic in several habitat types associated together at active margins.

\section{Secondary grassland and forest}

Neotropical Ericaceae are often found in disturbed sites such as recent landslides, or in disturbed habitats created by man (Luteyn 1989, 2002). Likewise, many Malesian Ericaceae occur in secondary vegetation. Habitats include land-slides, old gold workings, high road banks (Rhododendron: 182, 198, 201), earthen cliff faces, land-slides ... heath, infertile sandy or clayey soil; fern regrowth, sluiced areas or gullies in old gardens (31: $R$. herzogii), only in secondary vegetation (201), moss forest, also open sunny places and landslides (227), Miscanthus regrowth (Dimorphanthera: 4), 'blukar' (secondary) and grass vegetation (Vaccinium: 116), steep road cutting, old gold working (Vaccinium: 163), 'ladang' - land cleared for farming, shrubbery or fern scrub (Vaccinium: 195). Rhododendron: 232 is a locally endemic (Wissel Lakes) weed: 'secondary forest, locally common'.

242. R. macgregoriae is fairly common and locally abundant in primary forest, secondary brush, Imperata grassland, dry sunny sites, along creeks, on precipitous stream banks, landslides, formerly cultivated land, invading artificial clearings (airstrips), and on sand, peaty or stony soil, clay, and limestone.

\section{Volcanoes}

Many Vaccinium, Rhododendron and epacrid species in Malesia are closely associated with active or recently active volcanoes and their highly disturbed environs. Approaching almost every crater or solfatara field in Sumatra, Java and the Lesser Sunda Islands the percentage of the Ericaceae component increases, and they are among the plants which come closest to the sulphur vents. $V$. varingiaefolium is also able to withstand partial burial by acid volcanic mud. To a certain extent the Ericaceae may also be fire resistant (e.g. pure stands of 3-4 $\mathrm{m}$ high $R$. vanvuurenii in pyrogenous grassland in the Latimodjong Ra.).

This igneous ecology is also seen elsewhere. Neotropical Ericaceae are also frequently found near the craters of volcanoes (Luteyn 1989, 2002). In New Zealand, Gaultheria oppositifolia Hook.f., the only member of its genus with opposite leaves, ranges in the North Island in rocky and open places north of a line: Mt Egmont/Taranaki - National Park (Waimarino) - East Cape, to Tarawera, Matamata and Mayor Island, with a stronghold in the Rotorua-Taupo region (Franklin 1962). This distribution is closely aligned with a region (the 'volcanic plateau') dominated by Quaternary and recent volcanic activity of different kinds. Other endemics on the North Island volcanic plateau include taxa in Parahebe W.R.B.Oliver and Olearia Moench (Heads 1994b, 1998). Scaevola gracilis Hook.f. (Goodeniaceae), as revised by Sykes (1998), is endemic to volcanic areas of the same subduction zone further north, being known only from the Kermadec Is. and Tonga. Elsewhere in the Pacific, Ericaceae are endemic to isolated volcanic islands, e.g. Gaultheria ('Pernettya') howellii endemic at higher altitudes on Mt Crocker in the Galapagos Islands. These species are obviously well-adapted to life around subduction zones and, within their sector, have probably been colonising new volcanoes as they appeared for millions of years - much longer than the age of any individual volcanic island.

In Malesia, Rhododendron has the following species recorded at and around craters: 87 (only known from one collection, near a crater in W Java), 92 (crater walls, near solfataras etc.), 98 (dry sulfur stone slope), 125 (on volcanoes, in sandy grit or volcanic 
soil), 133, 136 (open, rocky places on old, dry volcanic soil, always near solfataras, capable of standing $\mathrm{SO}_{2}$ this is $R$. jasminiflorum, also known from sea-level in the Sarawak R. delta), 135 (narrow ridge in stunted forest on crater rim (New Georgia), 221,225 , and 267.

Several rhododendrons and Diplycosia 13 are recorded in burnt (i.e. open) ridges and summits. Other 'igneous' Ericaceae include Gaultheria 2, 10, and 15 in volcanic debris and near active craters and volcanic gases. Vaccinium 22 is on mudflows, 110 on stony mud flows, 89 is with Eucalyptus near the edge of craters (Timor), 109 on volcanic soil, Vaccinium 132 and 228 near cold solfataras, and 169 at crater edges.

Vaccinium 115 (V. varingiaefolium, photos in Sleumer 1967) occurs in old craters and on very young volcanic soil. 'It forms the main co-dominant in stands mixed with Eurya, Symplocos etc. of the subalpine forest on all (or most) Javanese mountain tops, chiefly above 1800-2000 m, not rarely in the form of a belt, growing as a tree in forest with rich humus as well as a shrub in open, extremely stony and rather dry places. It is a pioneer on ashy or volcanic soil of crater ridges, common in the vicinity of solfataras and hot mud-wells, and in such localities it descends to $1400 \mathrm{~m}$ [this lower altitude on active volcanoes supports Philipson's ideas, cited above, about survival of plants on oceanic volcanoes]. It becomes a small, more or less prostrate shrub in high, wind-exposed bare slopes up to $3340 \mathrm{~m}$, growing closely appressed to the ground. As a tree it is almost fire-proof; even when the whole trunk is charred, buds at the base of the stem may still sprout, thus holding its ground even in large numbers on mountains which are continually subject to bush fires.' (Sleumer 1967). Sleumer (1967 Fig. 104) illustrated prostrate shrubs in the crater of Mt. Papandajan, caused by the combined action of wind and sulphurous vapours from solfataras and but there is possibly also a genetic component. Studies of cultivated plants would be of interest.

\section{Ophiolite/Ultramafic terrane (= ultrabasics, serpentine)}

Stevens (1985) noted there are as many as five endemic species of Rhododendron from serpentine areas on Doormantop (including the distinctive 2: $R$. taxoides) and three species and one variety are endemic to Cyclops Mts., another area where serpentine occurs. Waigeo I. is an ophiolite terrane and has endemics like Rhododendron 160, Vaccinium 234. There is also notable bird endemism here (Heads 2002a). Other ultramafic endemics in Rhododendron include 157B: R. rousei (Argent and Madulid 1998) and 264C (Argent 1998) from the Philippines (177 is endemic to the same mountain as $264 \mathrm{C}$ and is probably another ultramafic endemic), and 268D (Argent and Barkman 2000) from Kinabalu. Also on ultramafics are Diplycosia 44 and 92, and Vaccinium 130 (all on both serpentine and granite), and Styphelia 156. S. abnormis is at Waigeo and nearby Gebe Islands on red clay with nickel and chrome. Elsewhere, the epacrids Dracophyllum uniflorum Hook.f. and Styphelia nesophila (DC.) Sleum. (= Cyathodes fraseri (A.Cunn.) Allan) are recorded on ultramafics in New Zealand (Mark and Adams 1979).

The New Guinea orogen is characterised by abundant outcrops of ultramafic rocks. The largest of these, the Papuan Ultramafic Belt (Bowutu terrane) covers an area $400 \times 40 \mathrm{~km}$ and is one of the world's most spectacular ophiolites. It forms a series of subsidiary mountain ranges north of the main ranges of the Papuan Peninsula and its emplacement must have been a major tectonic event.

Botanists have long recognised that these northern New Guinea ultramafics were strong foci of endemism (e.g. Kairothamnus Airy Shaw, Euphorb. (Airy Shaw 1980), Calophyllum streimannii Stevens, Guttiferae - (Stevens 1974b), Dioscorea sp. aff. nummularia Lamk. (Johns and Hay 1981), Freycinetia takeuchii Huynh, Pandan. (Huynh 2000)), and it was assumed that much of this endemism was due to edaphic rather than historical factors. However, Polhemus (1996) pointed out that many animals show similar patterns and that 
this correlation greatly weakens the edaphic hypothesis. Instead, Polhemus (1996) regarded the ophiolites as biogeographically significant because they are arc terrane markers. The most mature phase of arc collision is seen in old arc fragments now deeply embedded in modern mainlands such as New Guinea and the Philippines. The remnants of these Mesozoic arc systems have been crushed between even older arcs or continents but have left a biological signature in the disjunct distributions of living taxa.

Like the five Rhododendron species endemic there, Vaccinium 127 is on Doormantop, a high mountain with exposed ultramafic rock, and also $100 \mathrm{~km}$ to the east near Bernhard Camp, on the edge of the vast swamp-forest of the Meervlakte. The three species of the Grammitis mesocarpa group are restricted to the same sites (Parris 1983). The two localities might seem to have little in common ecologically, but both are on the Rouffaer terrane (Fig. 6), which consists of the Irian Jaya Ophiolite (Pigram and Davies 1987). Ultramafic rocks are only part of an ophiolite sequence, and with closer mapping 'ultramafic endemics' may prove, as here, to be 'ophiolite terrane endemics', restricted to the terrane and not just ultramafic-derived soils. The vegetation at Doormantop and that at Bernhard Camp represent two ecological aspects of the same terrane. Montane plants of the Doormantop show many dramatic disjunctions, but so do lowland plants such as Dacryodes (Burser.), a W Malesian group, known in Moluccas-New Guinea only from one record from the Idenburg R.(Leenhouts 1956).

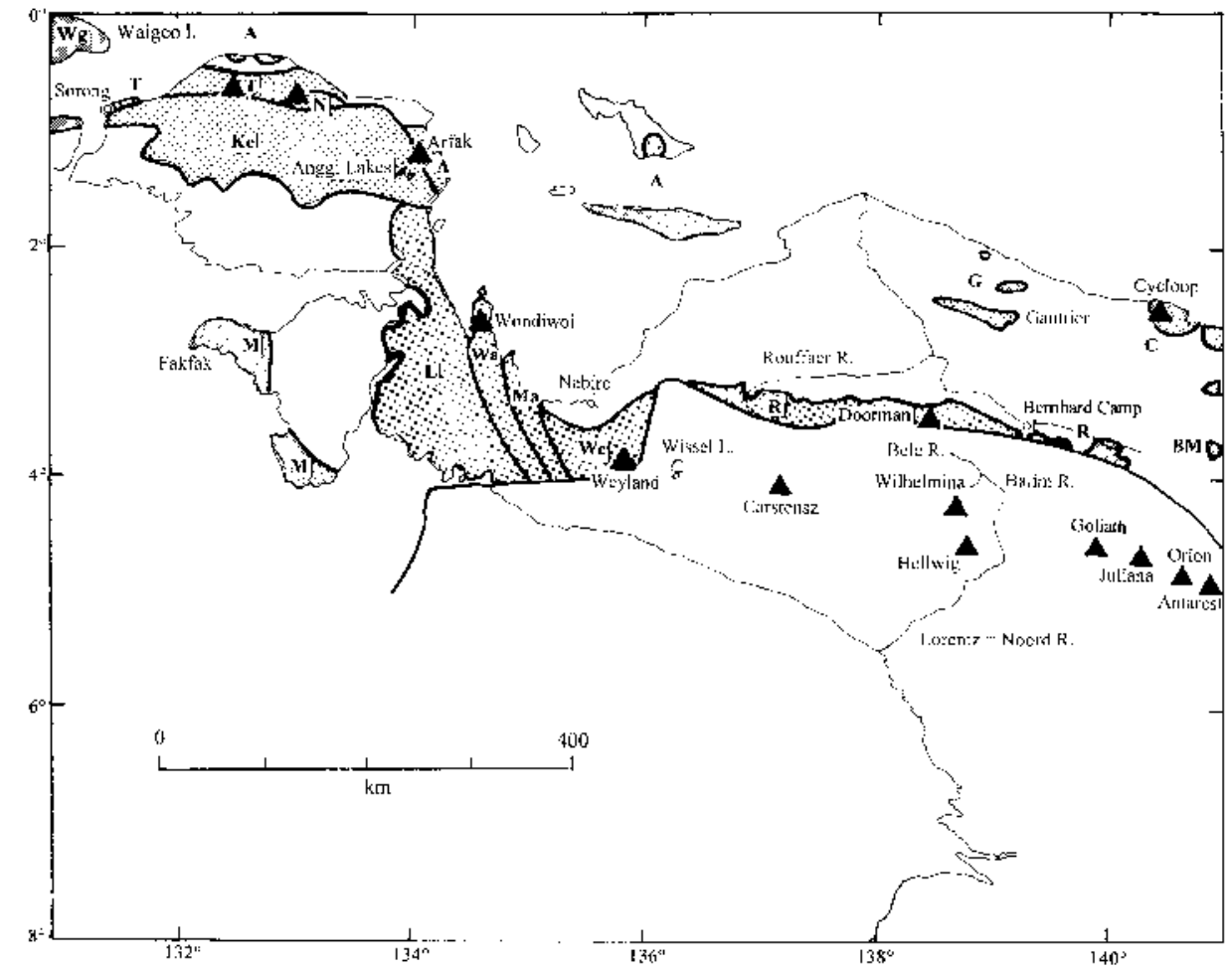

Fig. 6. West New Guinea (Irian Jaya, = West Papua) showing localities mentioned in the text, and accreted terranes (stippled) with abbreviations as follows: Wg, Waigeo; M, Misool; T, Tamrau; N, Netoni (with Nettoti Mts.); A, Arfak; Ke, Kemum; L, Lengguru; Wa, Wandammen; Ma, Mangguar; We, Weyland; R, Rouffaer; G, Gauttier; C, Cyclops; BM, Border Mountains. Former craton margin as heavy line to the south of the accreted terranes (Pigram and Davies 1987). 


\section{Limestone}

Plants which can tolerate basic sites have the potential to be very widespread in coastal areas in the tropics. Uplifted coral reefs and associated coral rubble ('karanas') and carbonate platforms occur throughout the northern coastal areas of New Guinea, for example, as well as further inland. Extensive carbonate sedimentation occurs in tropical waters while colder waters are undersaturated with $\mathrm{CaCO}_{3}$ and shells there dissolve on the death of the organism.

Thoughout the world most Ericaceae appear to be confined to acidic, quartzite- or sandstone-derived soils (Oliver 1991). However, there is a significant number of species recorded on limestone. The collector George Forrest reported the widespread occurrence of rhododendrons overlying limestone in western China, although at the time botanists in Britain took little notice. Kinsman (1998) measured soil pH at limestone sites with rhododendrons in Yunnan, and these were mostly below 6. Most species had their roots in the upper, acid part of the soil. Kinsman showed that in areas like Yunnan with an evenly distributed rainfall a water deficit is never developed and so water percolates downward through the soil profile at all seasons of the year. This water is generally acid through decay of organic detritus, and rainfall itself is acid. The plant is not exposed to the alkalinity of the underlying rock, whereas in areas like Great Britain a net water deficit, and thus an upward flux of water, often occurs.

Nevertheless, Kinsman (1998) found one species, R. primuliflorum, commonly anchored into small joints and cracks within the limestone, often hanging precariously off shear limestone cliffs. The plants had generally accumulated a small quantity of organic debris at their base, but even this material had a measured $\mathrm{pH}$ of 7.4-7.9.

Luteyn $(1989,2002)$ cited several Neotropical Ericaceae species on serpentine and limestone, growing in humus filled crevices.

Sleumer (1966) revealed the large number of Malesian Ericaceae species growing on limestone, including 23 species of Rhododendron (5b, 22, 30, 34, 39, 41, 50, 51, 53, 67, 72, 80, 95, 102 (stony areas), 105, 137, 139, 148 (Sleumer's 1973 record from 'griky' limestone hill is possibly a misreading of 'slimy'), 183, 204, 214 (abundant on limestone), 240, 242, 250, 255 and 271. 250. R. longiflorum and Vaccinium uniflorum can grow with some direct contact with bare limestone (Argent 1982). R. caliginis Kores (Hindenburg Ra., Victor Emanuel Ra., Laiagam-Porgera; 2400-2850 m) is a rather striking species both in its morphology and 'its apparent predilection for limestone outcrops' (Kores 1984).

Vaccinium species on limestone include: 7, 8, 10 (epiphyte in submontane heath forest, terrestrial on limestone), 16, 26, 27, 51, 72 (dry calcareous soil), 104, 185 (from seashore to $2400 \mathrm{~m}$, epiphyte in mossy forest, terrestrial on rather dry limestone rocks and near solfataras or chalk tuff terraces), 195 (forest; limestone rocks etc.), and 211 (primary forest, limestone).

Dimorphanthera 15 is in primary forest and on limestone, Dimorphanthera 33 is 'maybe on limestone ridges' (Sleumer 1967).

In Erica most species in southern Africa grow in quartzitic or sandstone habitats, but other species occur on the limestone or at least calcareous ridges of the south coastal plains. In pockets in calcrete there Oliver (1991) recorded a $\mathrm{pH}$ of 7.6 near the plants' roots and cited 30: Erica mariae Guth. \& Bol., 285: E. oblongiflora Benth. and species in Syndesmanthus Klotzsch and Thoracosperma Klotzsch (now treated under Erica) as endemics here (the species numbers follow Guthrie \& Bolus's 1905 Flora Capensis system, used also by Schumann et al. 1992). In Europe species such as E. carnea L., E. multiflora L. and E. sicula Guss. prefer, or are confined to, calcareous habitats. 
Erica in South Africa has many species in moist, sandy areas, especially flats, but there are quite a number of ericas which are confined to the limestone/calcified dune habitats that crop up along the coast from False Bay to near Mossel Bay (E.G.H. Oliver in litt. Dec. 2001). Schumann et al. (1992) recorded the following limestone species:

Sp. 29: On limestone hills as well as sandstone ('refuting the generalisation that some erica species grow exclusively on limestone whereas others prefer Table Mountain sandstone.')

Sp. 89: Riviersonderend Range and Caledon, reaching the coast at the limestone hills and flats near Pearly Beach.

Sp. 285: Very localised: limestone hills and stable dunes SW of Bredasdorp on or near outcrops or slabs of limestone.

Sp. 310: Widely distributed on sandy flats, on the Cape Peninsula associated with limestone deposits.

Sp. 311: Limestone hills and flats, sometimes forming dense colonies.

Sp. 399.1: (E. occulta E.G.H. Oliver): On rock ledges and boulders in limestone hills near Pearly Beach. The photograph of this 'most extraordinary' erica shows a plant growing directly out of a hairline crack in the bare, vertical rock.

Sp. 418.1: Only in limestone hills around Pearly Beach and nearby Stanford (both in W Bredasdorp District).

Sp. 418.2.: (E. calcareophila E.G.H. Oliver): only in limestone hills near Pearly Beach, usually prostrate where it grows on rocks.

Sp. 424: Limestone hills and rocks in the SW part of Bredasdorp District.

Sp. 448.3: Confined to a single reserve in Bredasdorp District: 'Along the shore of De Hoop Vlei [a small lake] it occurs on the limestone cliiffs (calcified dunes), whereas away from the vlei it may be found near watercourses, but still on limestone.'

E. sect. Gypsocallis D.Don, as the name indicates, the species occur mainly on limestone, in sandy, sometimes seepage areas.

Many of the calciphilous endemics in the Cape flora have vicariads on adjacent quartzite substrates (Cowling 1983), and this may also occur in Malesian Ericaceae although it does not seem to be documented.

Rouse (1985) noted that most rhododendrons are calcifuges; lime will kill them and lime leaching out of concrete will cause chlorosis. However, Rouse also observed that added calcium appears to improve the health and vigour of small seedlings as well as larger plants of Rhododendron, and that the leaves of healthy plants contain about $1 \%$ dry weight as calcium. It may be relevant that the presence of calcareous debris from coral and shells in the soil seems to be essential for the proper development of mangroves, particularly in areas of high salinity (Percival and Womersley 1975). As calcium reduces the level of internal sodium the presence of calcium ions seems to reduce or prevent any damage which may be done to the plant by an excess of sodium ions.

Many plants occur around both ultramafic rock and limestone or coral. Examples include Swintonia schwenkii (Anacard., Ding Hou 1978), Illigera celebica Miq. (Hernand., Duyfjes 1996), and Alocasia cuprea (C.Koch \& Bouché) C.Koch (Araceae, Hay 1998), from Malesia, and there are many others in New Caledonia and New Zealand. This relationship may reflect some similarity in the basic soils derived from these. 


\section{Swamps}

In West New Guinea, Archbold et al. (1942) described the Bernhard Camp vegetation cited above as an example of ophiolite vegetation. Here 'Pure stands of a six to sevenmetre high small Nauclea species, remarkably like a low Sonneratia alba mangrove community in appearance, covered flat islands in the upper end of the lagoon and sometimes fringed its banks. They grew on ground submerged to a depth of about 2.7-3.7 meters by the highest flood. Complete flooding was therefore the average condition from January 1 to May 8.' At the nearby Araucariakamp, 'flood resistant, low Ficus L. trees of two species and a Syzygium Gaertn., alike in their wide-spreading, horizontal branches, appeared on gravel bars and low banks as representatives of a stream community found everywhere in the low mountains of New Guinea.'.

Although many Malesian Ericaceae require good drainage and light, and so are lithophytes or epiphytes, a significant number occur in sites that are at least periodically waterlogged, such as semi-swampy open places, peat moor, peat bogs, and wet ground with mosses and lichens (a particularly ancient habitat). Swamp habitats are characteristic of rifted areas and plate margins, e.g. the Mamberamo-Sepik-Ramu depression in New Guinea, and along the Alpine Fault Zone in New Zealand.

Many Ericaceae are recorded in swampy habitats. For example, Rhododendron is in shrubland on poor impervious white clay (28), moss forest in damp ground or swampy places (30), swampy jungle on white sand podsols at low elevation (233, Sarawak), swamps near lake-shore (248, Sleumer 1966: Fig. 40), Agathis forest, waterlogged white acid sands and on granite rock faces (274), and along rivulets, rocky places by rivers, and in riverine forest (229).

Costera is in acid, waterlogged sandy soil, sometimes with Agathis $(4,8)$.

Vaccinium is recorded in open marshy places (6), marshy forest (22), and Miscanthus grass swamp $(33,95)$.

Other swampy habitats include: swampy forest (Diplycosia 3, Vaccinium 75), semiswampy alpine thickets (Diplycosia 33), marshy flats, bogs or wet flats in alpine grassland (Vaccinium 56), sandy or swampy soil (Vaccinium 61), swampy shrub vegetation and swampy Dacrydium forest (Vaccinium 66), boggy area in Nothofagus forest, also Miscanthus grass swamp (Vaccinium 95), swamp (Vaccinium 121), Agathis and Quercus forest on acid, waterlogged sand, kerangas, low scrub (Vaccinium 151), and swampy sites (Vaccinium 207).

Dimorphanthera 38 occurs on the margin of Metroxylon (sago-palm) swamp, Dimorphanthera 28, 30 and 31 are all riverine.

The 'marsh ericas' of South Africa are a diverse group with slender, wiry branches and distant leaves (Schumann et al. 1992). Most (e.g. species 147.1, 147.2, 149, 149.2, 149.3, $149.4,149.5$ ) are confined to a very small area, sometimes a single marsh. Sp. 334 grows in sandy soil which may be moist in winter, but quite dry in summer. 341: grows in hard, gravelly soil that is usually wet in winter.

\section{a. Mangrove}

Eighteen Malesian Ericaceae species occur below $100 \mathrm{~m}$ and many of these are associated with maritime conditions. For example, Rhododendron 250 (R. longiflorum) of Sumatra and Borneo is epiphytic in high trees in mangrove, along rivers and in primary and secondary forest, terrestrial in poor forest in stagnant water, in extreme kerangas heath forest, and on quartzite ridges and sandstone pavement. 
Rhododendron 276 (R. brookeanum, Borneo) occurs from sea-level, where it is epiphytic on mangrove or on rocks, to $1525 \mathrm{~m}$ altitude in moss forest, especially on trees along rivers.

136: R. jasminiflorum, usually epiphytic, has named varieties at Mt Ophir, Peninsular Malaysia (sometimes terrestrial on rocks in more open places), the Cameron Highlands, the summit of Mount Apo, Mindanao (ridge forest, moss forest and thicket), and the Gajo Lands (open rocky places and old dry volcanic soil always near solfataras, where it is able to withstand $\mathrm{SO}_{2}$ ). The fifth variety is known from the Peninsular Malaysia and Borneo where it normally occurs in mountain forest, but it was once found 'almost at sea level' in the delta of the Sarawak River (whether epiphytic or terrestrial is not recorded).

New Guinea species of old sandy clearings in mossy forest (Rhododendron 189) and forest opening of long standing (Vaccinium 122) may be taxa of gaps on the uplifted coastal land surfaces which are abundant in New Guinea, for example Neon Basin in the Owen Stanley Mts. (formed at sea-level but currently at $2800 \mathrm{~m}$ ).

Vaccinium 27 is recorded from mangrove near Kuching, and other species are on sandy coasts.

In the Neotropics, Ericaceae are most common in areas of cloud forest at 1000-2000 m altitude and some extend up to $4000 \mathrm{~m}$. However, 'a few' occur as epiphytes in mangrove swamps (Luteyn 2002, citing Smith 1946). Luteyn (2002) also observed vivipary in several New World Ericaceae.

Many taxa are found in close association with mangrove, but not always in the main mangrove swamp, and Mepham and Mepham (1985) made the reasonable suggestion that a broad definition of mangrove is desirable. In New Guinea, mangroves in a fairly broad sense include species like Cerbera manghas L.: swamp forests near the sea or beach formations, preferring well-drained sandy soils, and Dolichandrone spathacea (L.f) Sch.: in areas only flooded by spring tides, usually on the coastal dunes separating freshwater lagoons from the sea, although it can form almost pure stands behind the mangrove in swamp soils (Percival and Womersley 1975).

Continuously water-logged mangrove peat soils and other saline peats and muds of the coast have a neutral to alkaline reaction in saturated conditions, becoming acid on aeration (Bleeker 1983). In New Guinea mangroves Percival and Womersley (1975) noted that the $\mathrm{pH}$ of the soil in the Avicennia and Rhizophora zones is alkaline, while that of the Nypa zone falls gradually to an acid level.

Erica ('Philippia') occurs at sea-level on Mafia Island, Tanzania, and maritime species of Erica in South Africa include the following (Schumann et al. 1992):

Sp. 70: This shows apparent resistance to salt spray. It never grows very far from the sea and is sometimes (e.g. at False Bay) found amongst rocks so close to the breakers that in stormy weather it becomes quite wet.

Sp. 256: (E. subdivaricata Bergius) has a spreading habit, and grows on level ground in sandy conditions that may be marshy in winter. The plants are not inhibited by salt air or spray and may even grow quite well only a few hundred yards from the sea.

Other Malesian Ericaceae occurring under 100 m are listed below, under 'Altitude'. 


\section{b. Freshwater swamp forest}

22: Vaccinium acuminatissimum and 87: V. bracteatum occupy the lowland fresh-water swamp forest of Peninsular Malaysia (Corner 1978a). This type of forest shows clear affinities with the mangrove, as indicated by the massive stilt roots, flanges, fluting and buttresses (spectacular photographs in Corner 1978a and Ding Hou 1978 Figs 25, 26). Freshwater swamp forest in New Guinea (for example, in the Sepik Valley) with Myristica, Calophyllum, Eugenia, Terminalia and Campnosperma is flooded daily, at least near the coast, and 'is well-termed 'freshwater mangrove" (Johns 1972, Paijmans 1976). The distinction between mangrove and freshwater swamp forest may have been even less in the past if the salinity of sea-water has been constantly increasing.

\section{c. Peat-swamp forest}

Acid soils usually occupied by Ericaceae are poor in nutrients but those of marshes, seeps, or streambanks are high in organic humus (Oliver 1991). In Europe, Calluna and Erica can grow where most other shrubs cannot, in pure organic matter such as Sphagnum peat. In South America, a plant of Lyonia was growing in soil measured at pH 2.8 (Luteyn 1989). Here and elsewhere Ericaceae share this habitat with other 'heathland' families such as Myrtaceae, Droseraceae, Nepenthaceae and Restionaceae.

The tallest vegetation on peat in Malesia is peat swamp forest (Anderson 1963). This is the acidic environment equivalent of mangrove and is widespread along the coasts and deltas of Malesia. It is considered to be 'an outcome of fresh-water swamp-forest, behind the mangrove and nipa, where for some reason the water-logged soil is no longer subject to tidal inundation or disturbed by the passage of streams' (Corner 1978a). The forest debris accumulates into huge thicknesses of peat and there is no enrichment of the soil with silt. The swamp water is tea-coloured, extremely acid and anaerobic. Peat swamp forest covers $12 \%$ of the land in Sarawak, and also large areas in Sumatra and southern New Guinea (Anderson 1963). The Rejang Delta is the largest in Sarawak and each island in it forms a self-contained peat-swamp unit, bounded by a fringe of mangrove or riparian forest. Anderson (1963) recorded Vaccinium borneense in peat swamp forest only in the Rejang Delta, but throughout Sarawak and Brunei in heath forest.

Also recorded in peaty sites are Rhododendron 29 (temporarily inundated grass-plain on peaty soil), Diplycosia 66 (padang, peat swamp forest, kerangas with Shorea albida, 60-800 m), Diplycosia 77 (peaty, swampy quartzite, open forest), Diplycosia 97 (secondary Dacrydium forest or heath vegetation or in swamps, temporarily covered by water, on peaty soil), Diplycosia 96 (swampy or peaty sites), Vaccinium 24 (submontane and moss forest but also in 'low country', in the shrub layer of a Shorea albida padang on peat swamp), Vaccinium 113 (peaty quartzite plateau), wet, peaty openings in forest, open shores of lake, long grass in open marsh (Vaccinium 54) and Dimorphanthera 21 (peat swamp).

\section{d. Kerangas forest and padang}

These are coastal and lowland communities. Kerangas, or closed heath-forest, occurs in Borneo and other parts of Malesia on poor sandy soils which are strongly podzolised or even seasonally waterlogged to form humus podzols and ground-water humus podzols. Like mangroves they are periodically inundated. On increasingly poor sites, e.g. areas with a rapidly fluctuating water table, or in sandy soil on rocks with excessive drainage, the kerangas is replaced by open shrubland or padang.

In Borneo, heath forest occurs between peat-swamp forest and lowland dipterocarp forest (map in Mackinnon et al. 1996). 


\begin{abstract}
Altitude
Fig. 5 indicates the major altitudinal sequence in Malesian Ericaceae from epiphytes in mangrove and lowland forest to terrestrial plants at and above alpine tree-line and in forest gaps. This ecological 'track' follows a zone of high light. Ericaceae occupy the zone because they possess critical morphological/physiological features:
\end{abstract}

- They are smaller, woody plants seldom forming a trunk that reaches the canopy.

- They are light-demanding.

- They tolerate a low supply of mineral nutrients.

- They have thick, water-storing, mycotrophic roots and coriaceous, xeromorphic leaves, and they tolerate high drainage.

It is often thought that all Ericaceae in the tropical regions thrive in the mountains. This is indeed the case for the bulk of the species but in the four largest Malesian genera, Rhododendron, Diplycosia, Vaccinium and Dimorphanthera, many species occur below $1000 \mathrm{~m}$ altitude and some of these, e.g. 87: $\mathrm{V}$. bracteatum, thrive mainly in the tropical lowland at sea-level.

Table 1. Numbers of species of Malesian Ericaceae in $\mathbf{5 0 0 ~} \mathrm{m}$ altitudinal bands. Based on literature records.

\begin{tabular}{|c|c|c|c|c|c|c|c|c|c|}
\hline ALTITUDE/m & $\begin{array}{l}0- \\
500\end{array}$ & $\begin{array}{l}500- \\
1000\end{array}$ & $\begin{array}{l}1000- \\
1500\end{array}$ & $\begin{array}{l}1500- \\
2000\end{array}$ & $\begin{array}{l}2000- \\
2500\end{array}$ & $\begin{array}{l}2500- \\
3000\end{array}$ & $\begin{array}{l}3000- \\
3500\end{array}$ & $\begin{array}{l}3500- \\
4000\end{array}$ & $\begin{array}{l}4000 \\
4500\end{array}$ \\
\hline Rhododendron & 13 & 46 & 98 & 143 & 131 & 96 & 81 & 28 & 3 \\
\hline Andresia & . & . & 1 & . & & & & & \\
\hline Monotropastrum & . & . & 1 & 1 & & & & & \\
\hline Pyrola & . & . & . & . & . & 1 & & & \\
\hline Lyonia & . & 1 & 1 & 1 & 1 & & & & \\
\hline Pernettyopsis & . & . & 1 & 2 & 1 & 1 & & & \\
\hline Gaultheria & . & . & 5 & 8 & 11 & 16 & 13 & 5 & 1 \\
\hline Diplycosia & 3 & 16 & 38 & 56 & 41 & 32 & 17 & 6 & \\
\hline Costera & 3 & 6 & 7 & 2 & & & & & \\
\hline Vaccinium & 28 & 55 & 91 & 121 & 98 & 73 & 51 & 23 & 2 \\
\hline Agapetes & . & . & 3 & 4 & 8 & 6 & 6 & 3 & \\
\hline Dimorphanthera & 12 & 20 & 24 & 32 & 22 & 13 & 13 & 5 & 1 \\
\hline Styphelia & 3 & 3 & 2 & 3 & 3 & 4 & 3 & 1 & 1 \\
\hline Decatoca & . & . & . & . & . & 1 & 1 & 1 & \\
\hline Trochocarpa & . & 1 & 1 & 4 & 5 & 7 & 5 & 5 & \\
\hline TOTAL & 62 & 148 & 273 & 377 & 321 & 254 & 190 & 77 & 8 \\
\hline
\end{tabular}

Table 1 shows that the four largest Ericaceae genera in Malesia and the family as a whole have most of their species in the 1500-2000 m band, in the lowest part of the montane zone. This is within the range of sweet potato (kaukau) cultivation (below about $2400 \mathrm{~m}$ ) and so is potentially very vulnerable. Highest diversity for ferns (Parris 1996), birds-of-paradise and bowerbirds (Heads 2001c), and Ericaceae occurs in the 
same 1500-2000 m band. Of the other Ericaceae, Agapetes is most diverse at 2000-2500 m, and Gaultheria and the three epacrid genera, all with small leaves, have maximum diversity at the highest altitudes, in the 2500-3000 m belt.

Takeuchi (1999a) observed that the lowland-montane ecotone around $1500 \mathrm{~m}$ has been somewhat neglected in Papuasia, but cited recent unpublished findings suggesting that floristic richness in Papuasia peaks at or near this altitude. (It may be more useful to focus on these altitudinal centres of diversity, rather than defining supposed 'breaks' between 'lowland', 'lower-', 'mid-', and 'upper-montane', and 'subalpine'). Stevens (1981) noted elevations of $1500 \mathrm{~m}$ or more in New Guinea during the Miocene, 15 million years BP, and it is of interest that this is the belt with most diversity of Ericaceae.

To explain the large-scale variations in altitude discussed below, a general explanation for the altitudinal sequence of taxa is needed. Many authors have discussed affinities between the flora of mangroves and that of the montane zone. Van Steenis (1934b) cited the 'instructive case of altitudinal vicariism' seen in Bulbophyllum tenellum Lindl., only in mountain forest at 1000-1500 m, and its nearest relative, B. xylocarpi J.J.Sm., only at sea-level on mangroves, but how is this to be explained?

Van Steenis (1934b) noted that 'In the Malaysian lowland there are peculiar, natural open sandy plains called padangs ... They are situated mostly near sea-level ... several plants descend here to their lowest altitude'. A comparison can be drawn with the Awarua plains of southern New Zealand. Van Steenis took a fundamentally geological approach to the problem and reasoned that 'The possibility of the occurrence of mountain plants at abnormally low altitudes on account of secular sinking cannot be denied.' Van Steenis (1934b) cited possible tectonic lowering of mountains and plant communities in SE Sumatra (for the Riouw Pocket (Corner 1978a), see below). In a classic but forgotten paper Krašan (1883) discussed sinking land in SE Asia and Malaysia in relation to plants having a lower altitude in Sumatra than in Java, and rejected the idea that climate could be responsible - rightly, according to van Steenis.

Conversely, van Steenis (1934b) cited 'abnormally high altitudes [of taxa] in regions which are gradually elevated' and cited Krašan's (1883) studies on tectonic uplift of oak forest in the European Alps. Later, van Steenis $(1963,1984)$ recorded mangroves in Malesia which have been stranded inland through tectonic uplift, and Hossfeld (1964, cited in Löffler 1977) recorded a former tidal mangrove at Aitape (NW coast of PNG), $13 \mathrm{~km}$ inland and $52 \mathrm{~m}$ above sea-level. In fact, current uplift rates in northern New Guinea ( $3 \mathrm{~mm} / \mathrm{yr})$ would move a mangrove or a coastal padang to the high montane (3000 m) in just one million years. Kinabalu is said to have risen at $5 \mathrm{~mm} / \mathrm{yr}$.

Although it might appear that birds and rhododendrons move freely and the mountains stay still, birds and rhododendrons may actually stay in their own locality, while the mountains move up, down and sideways.

Another example from Malesia is Scolopia rhinanthera (Benn.) Clos (Flacourtiaceae), which always grows in humid or marshy soil along the land-side of mangrove forests or more inland on riversides, at margins of pools or in temporarily inundated soil, usually at $0-15 \mathrm{~m}$. 'Quite out of this area' are two specimens growing at $900 \mathrm{~m}$ south of Lake Toba in northern Sumatra (van Slooten 1925).

Hydrophiidae, the sea-snakes, are widespread in tropical seas, but there are two species confined to freshwater lakes (Dunson 1975). One is in Lake Taal in southern Luzon, which occupies an ancient crater and is itself occupied by the volcano Taal (Smith 1926). The other is in a lake on an uplifted coral island (Rennell I.) in the Solomon Islands (a 'distributional anomaly' (Minton 1975)). 
Nearly a century ago in the upper Ramu Valley at Kenejia, Schlechter was surprised to find typical sea-shore plants such as the orchid Dendrobium antennatum Lindl. (Schlechter 1982). Schlechter also noted uplifted coral at $600 \mathrm{~m}$ on the Huon Peninsula and reasoned correctly that the Ramu-Markham valley was previously flooded by the sea, but that subsequently an 'enormous elevation' had joined the Huon Peninsula to the mainland.

Brookfield and Hart (1971) described the raised beaches on the Huon Peninsula and also observed that on the southern plain of New Guinea some forest is being actively transformed into swamp forest through depression along axes transverse to the central cordillera.

In New Guinea plants many other 'altitudinal anomalies' are known in which a group has unusual altitude at certain geographic localities.

At Kiunga in the upper Fly River, Stevens (1981) described 'altitudinal irregularities' in the flora; species of otherwise montane genera, or species otherwise known at higher altitude are present here on ridges at only $100 \mathrm{~m}$ elevation (Dimorphanthera, Vaccinium, Podocarpus, Lithocarpus, Calophyllum). In the same area montane birds also occur at anomalously low altitude (Heads 2001b).

At another site in southern New Guinea, in the Lakekamu basin SW of Wau, Takeuchi and Kulang (1998) reported 'unexpected' montane genera in families such as Ericaceae, Monimiaceae, Elaeocarpaceae, Winteraceae, Ternstroemiaceae and Pittosporaceae at anomalously low altitude $(175 \mathrm{~m})$, very near the alluvial-coastal plain. Individual species are found there far below their previously known lower limit. Takeuchi (2000) described a new subspecies of 133: Rhododendron loranthiflorum from the site and inferred the apparent displacement of an entire montane assemblage to the Papuan lowland environment where the non-conforming elements now coexist in disparate combination with the conventional lowland flora.' As Takeuchi and Kulang (1998) noted, these records are 'rather provocative and deserving of further enquiry'.

Whether the 'montane' elements occur at low altitude through downwarping of terranes bearing these populations, or because there has been relatively little uplift there compared with the main central mountains, it seems unrealistic to discuss the altitudinal range of communities and taxa without reference to the changes of a site's altitude caused by orogenic and epeirogenic uplift, vulcanism, sedimentation, downwarping and erosion.

The following species of Malesian Ericaceae are of interest as they occur at or below $100 \mathrm{~m}$ :

\section{Rhododendron:}

136: R. jasminiflorum. Aceh to Mindanao, 'Almost at sea-level in the Sarawak R. delta'; also in thicket, open rocky places, mountain forest, sea-level $-3100 \mathrm{~m}$.

163: R. nieuwenhuisii. Borneo, dense forest along river, heath forest, 100-800 m.

250: R. longiflorum. Sumatra, Peninsular Malaysia, Borneo, including Riouw pocket, mangrove etc., sea-level - $750 \mathrm{~m}$.

255: R. zoelleri. Moluccas and New Guinea, sandy and clayey soil, limestone, sea-level $2000 \mathrm{~m}$.

276: R. brookeanum. CW Sumatra and widespread in Borneo, mangrove etc., sea-level$1750 \mathrm{~m}$. 
Vaccinium:

21: Borneo, on boulders, 5-200 m.

27: Sarawak, limestone, mangrove, sea-level - $700 \mathrm{~m}$.

87: Burma to Java, common locally on sandy coasts, padang, sea-level $-1830 \mathrm{~m}$.

88: Sulawesi, dry forest, sea-level - $850 \mathrm{~m}$.

158: Sumatra, Riouw Pocket, Borneo, beach, padang, kerangas, sea-level - 1700 m.

165: Borneo, padang, acid sand, sea-level only.

185: (V. littoreum Miq.), Sumatra, Malay Peninsula, Java (not Riouw) limestone etc., sea-level - $2400 \mathrm{~m}$.

Diplycosia:

52: Borneo, Sarawak, mossy and Agathis forest, acid, sandy-loam soil or sandstone, 20-1000 m.

65: Sarawak, padang, kerangas, 60-800 m.

Dimorphanthera:

3 (included under sp. 7 by Stevens 1974): lower Mamberamo R., Irian Jaya, primary forest, $75-100 \mathrm{~m}$.

66: D. tedentii Stevens. 80 m (Fly River 528 Mile Camp) - 835 m.

Styphelia

3: Indo-China to Borneo (including Riouw, Banka, Billiton, and Karimata Islands),

exposed cliffs or rocks, sandy beach plains, 'blukar' (secondary vegetation) behind coconut groves near the sea, kerangas, padang, etc., sea-level - $2745 \mathrm{~m}$.

7: Borneo, Sulawesi, Moluccas, Waigeo I., xeromorphic vegetation on red, nickel- and chrome-containing clay, sea-level - $1000 \mathrm{~m}$.

Summarising, of the 18 Ericaceae more or less definitely recorded from below $100 \mathrm{~m}$, only three (16\%) occur in New Guinea, one ranges between Borneo and Waigeo, while $14(78 \%)$ occur in W Malesia.

A very similar pattern is seen in Nepenthes. This genus has 82 species in Malesia (Cheek and Jebb 2001) of which 13 occur at sea-level. All of these 13 are in W Malesia except one at the Vogelkop (Sorong) and nearby Misool I., and only this species and one wide are in New Guinea. As in the Ericaceae, coastal species are much more frequent in W Malesia. In Ericaceae there are mangrove species in Sumatra: Borneo, Nepenthes is recorded in the mangrove at Sulawesi. The distribution of another species, N. mirabilis, illustrates the general pattern: at low altitude in the west, but at anomalously high altitude in New Guinea.

This pattern in the two families could be attributable to Mesozoic ancient invasion of the Malesia/SW Pacific region from the Indian Ocean by mangrove and coastal forms, followed eventually by great uplift of these in E Malesia during the Neogene. This is compatible with the sea-level species Nepenthes danseri of Ceram being sister to the Madagascan species (Jebb pers. comm. 2001).

In a similar example, Buchanania macrocarpa (Anacard.) is widespread in E Malesia through the Moluccas, New Guinea, and the Solomons, occurring in the lowlands up to $450 \mathrm{~m}$. However, it was once collected at $900 \mathrm{~m}$ in northern PNG (Morobe) (Ding Hou 1978). Still in Anacardiaceae, a similar W-E altitudinal cline in New Guinea is 
seen in Rhus caudata Laut. This ranges in New Guinea mossy montane forest at 900-2400 m, but was once found at $10 \mathrm{~m}$ on Biak Island on a wet, coastal coral limestone ridge (Ding Hou 1978).

Likewise, Meliosma pinnata subsp. macrophylla (Merr.) Beus. (Sabia.) is a tree of primary rain forest with buttresses to $2.5 \mathrm{~m}$ high, fairly common from E Borneo (within Borneo it is sharply delimited against the W Malesian ssp. ridleyi) through Sulawesi, the Moluccas, New Guinea and New Britain (van Beusekom 1971). It occurs on loam, sandy soil, volcanic and limestone soil, and rarely in occasionally submerged areas. It was reported once on peaty soil (in New Guinea) where it was developing stilt roots. In Borneo it only occurs below $100 \mathrm{~m}$, but further east it ranges up to 1100-1200 m, and in W New Guinea it has been collected at $1800 \mathrm{~m}$.

Xylosma G.Forst. (Flacourt./Salicaceae) has four species in Malesia. The two in W Malesia have serrate leaves and occur from the sea-shore (thickets back of the beach etc.) to 200 and $1200 \mathrm{~m}$ respectively; the two species in New Guinea (one is also in W Malesia) have entire leaves and are at distinctly higher altitudes: 400-1600 m and 1070-2200 m (Sleumer 1954).

\section{Floral biology}

Stevens (1976, 1985) described the great variety of flower types in Papuasian Rhododendron. These are not distributed at random, either geographically or altitudinally. For example, in Papuasia there are 36 species with red, tubular, zygomorphic, scentless flowers, and with one exception (199B: R. yongii of Sabah) this type is only known from here. Another 40 species in Papuasia have similar flowers but with little zygomorphy and this type occurs in some W Malesian species.

In Papuasia nearly 50 red-flowered species grow above $3000 \mathrm{~m}$, but only 9 species with flowers of other colours grow much above this altitude. Birds remain active at all temperatures and are probably more important pollinators at this altitude than insects, and Ericaceae may be an important source of nectar for groups such as Meliphagidae. Below $3000 \mathrm{~m}$ white-flowered, moth-pollinated species also occur. (The absence of alpine lepidoptera in New Guinea compared with their abundance in New Zealand is striking).

\section{Ericaceae in Malesia - systematic treatment}

The Ericaceae of Malesia have been treated by Sleumer $(1966,1967,1973)$ with 737 species, of which 236 were newly proposed by him (van Steenis 1979). Sleumer (1964) also treated Malesian Epacridaceae (18 species), here included in Ericaceae. Other authors have since described 32 new species, and Dimorphanthera alba J.J.Sm. and D. arfakensis J.J.Sm. have been reinstated. Six Rhododendron species are now regarded as hybrids by Argent and colleagues, and six Dimorphanthera species have been synonymised. This gives a total of $737+18+34-12=777$ species in Malesia. Photos of the types of most of Sleumer's taxa and many other Malesian Ericaceae are available at www.nationaalherbarium.nl

New taxa have been described from New Guinea by Stevens (1972, 1974a, 1977, 1978a, 1982), Kores (1978,1984), Veldkamp (1979, 1991), Craven (1980), and Takeuchi (2000). R. heptaster Gilli 1980 and R. sleumeri Gilli 1980 were synonymised by Kores (1984).

Two important floristic studies by Takeuchi (1999a,b) have several interesting Ericaceae records, as does Streimann (1983). 
Working on Rhododendron in Borneo, Argent and co-workers (1982-2000) have described nine new species, six new subspecies and varieties, changed the status or made new combinations for ten taxa, and have treated six of Sleumer's species as hybrids. Argent et al. (1996) listed all the species in $R$. sect. Vireya, with synonyms. Argent (1982) also described a new species in each of Costera, Vaccinium, Diplycosia and Pernettyopsis, all from Sabah.

Van Royen and Kores (1982) treated the many species of Ericaceae found above $3000 \mathrm{~m}$ in New Guinea. This valuable supplement to Sleumer's work included many new localities, altitudinal records, habit photographs, and drawings showing important features such as perulae. Stevens $(1976,1981,1985)$ studied many aspects of morphology, architecture, ecology, biogeography and evolution in New Guinea Ericaceae. Argent et al. (1988) treated the Sabah species of Rhododendron.

Middleton (1991) gave a detailed revision of the infrageneric classification of Gaultheria, including Pernettya.

Species described after Sleumer (1973).

Sleumer's (1973) new species are listed in the maps with the number of their putative relative and a suffix ' $\mathrm{A}$ ' (or ' $\mathrm{B}$ ' in cases where there is more than one new, related species), but are not listed separately here. Other authors' new species are listed here, with a suffix, and are also mapped. 131A was first named by Sleumer, then lumped by him in the Flora Malesiana ('partly under the influence of badly prepared material'), but later revived (Sleumer 1973).

Rhododendron

23A: R. capellae Kores (1978).

41A: R. caliginis Kores (1984).

82A R: lamrialianum Argent \& Barkman (2000).

105A: R. roseiflorum Stevens (1975).

131B: R. alborugosum Argent \& Dransf. (1989).

137A: R. rubineiflorum Craven (1980).

155A: R. burttii Woods (1978).

157B: R. rousei Argent \& Madulid (1998).

192A: R. meijeri Argent, Lamb \& Philipps (1984).

199B: R. yongii Argent (1982).

227A: R. sarcodes Argent \& Madulid (1995).

264B: R. madulidii Argent (1998).

268C: R. baconii Argent, Lamb \& Philipps (1984).

268D: R. tuhanensis Argent \& Barkman (2000).

Agapetes

2A: A. prostrata Stevens (1972).

3A: A. kudukii Veldk. (1991).

9A: A. sleumeriana Stevens (1972).

11A: A. shungolensis Stevens (1972). 
Vaccinium

2A: Dimorphanthera albida Stevens (1977). (Sect. Pachyanthum is retained here in Vaccinium instead of being transferred to Dimorphanthera).

54A: V. candidum Veldk. (1991).

23A: V. tenax Argent (1982).

58A: V. altiterrae Veldk. (1979).

Dimorphanthera

11A: 17A. D. tedentii Stevens (1974a).

44A: D. viridiflora Stevens (1974a).

51A: D. bracteata Stevens (1974a).

52A: D. glauca Stevens (1974a).

54A: D. papillata Stevens (in van Royen and Kores 1982).

55A: D. longistyla Stevens (1974a).

64A: D. napuensis Stevens (1977).

64B: D. wisselensis Stevens (1977).

Pernettyopsis megabracteata Argent (1982).

94A: Diplycosia microsalicifolia Argent (1982).

The distributions of the Malesian Ericaceae species are mapped here and related to the geological structure of SE Asia-Malesia, summarised in terrane maps (Figs. 6, 7 and 8). Many of the sutures between the terranes are Jurassic, a time during which an important phase of modernisation took place in the flora and fauna of the world (cf. Heads 1989, Parenti 1991).

\section{Rhododendron L.}

Many of the papers cited below are available at the outstanding website devoted to the Vireyas, www.vireya.net. Rhododendron species range from $R$. rex of western China with leaves up to $37 \mathrm{~cm}$ in length, to the miniature R. caespitosum from Irian Jaya with leaves $0.6 \mathrm{~cm}$ long, $R$. stenophyllum of Kinabalu in which the leaves resemble pine needles, and $R$. ericoides of Kinabalu which is like a heath. The largest flowers in the genus belong to two northern New Guinea species, 238: R. leucogigas (Cyclops Mts. and Hunstein Mts.) with flowers trumpet shaped and $14 \mathrm{~cm}$ long, and its sister species 237: R. schlechteri (Bismarck and Kani Mts.) with a corolla 15-17 cm long. Style length varies from $4 \mathrm{~mm}$ (R. anagalliflorum) to $100 \mathrm{~mm}$ (R. leucogigas).

Halliday (2001) illustrated 121 species representing all the subsections and series in the genus. Apart from Vireya, Halliday illustrated many species from SE Xizang (= Tibet) - NE Upper Burma - N Yunnan. Sikkim, Bhutan and Sichuan (Szechuan) are also very diverse. The 'centre of gravity' of Rhododendron was previously thought to lie in the Himalayas, but after the collecting of the French missionaries it was acknowledged to lie further east, in Yunnan/Sichuan (Philipson and Philipson 1974).

There are many morphological and ecological parallels with the vireyas elsewhere in Rhododendron. The following examples are cited from Halliday (2001).

R. hippophaeoides Balf.f. \& W.W.Sm.: Yunnan, SW Sichuan, boggy ground, spread over vast tracts of land forming an ankle-deep carpet. Up to $4800 \mathrm{~m}$. 


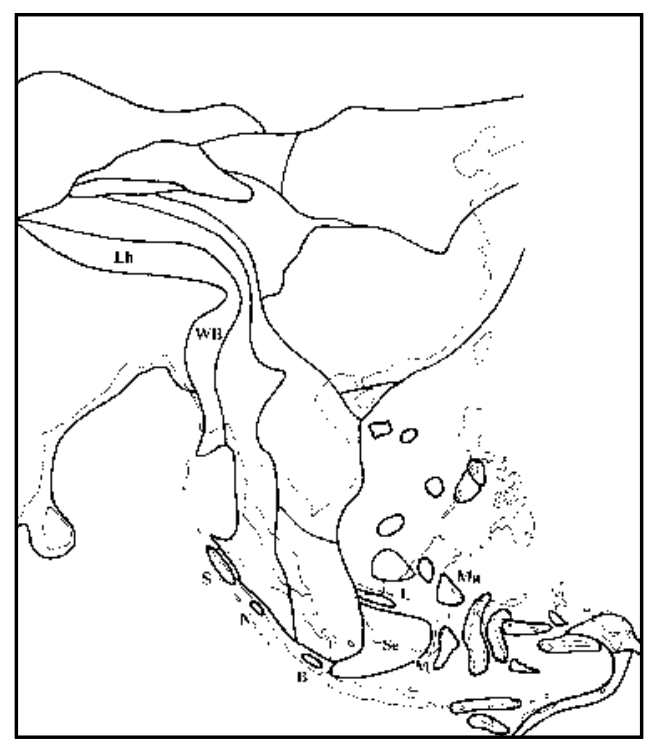

Fig. 7. Continental allochthonous terranes and principal sutures of SE Asia. The following examples are labeled: Lh, Lhasa terrane; W B, West Burma terrane; S, Sikuleh terrane; N, Natal terrane; B, Benkulu terrane; L, Lupar suture; Se, Semitau terane; M, Meratus suture; Ma, Mangkalihat terrane (Metcalfe 2001).

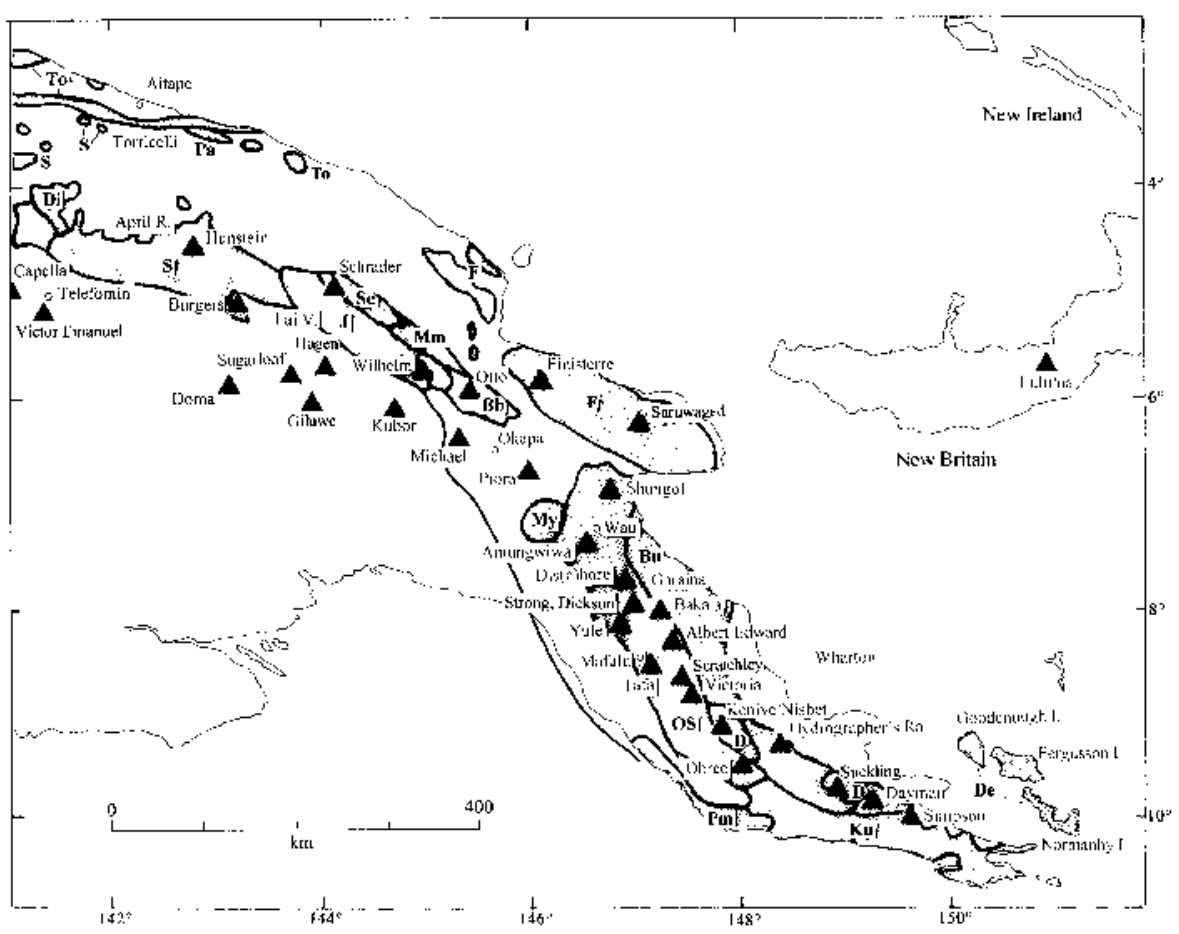

Fig. 8. Papua New Guinea, showing localities mentioned in the text, and accreted terranes (stippled) with abbreviations as follows: To, Torricelli; S. Sepik; LS, Landslip; Di, Dimaie; Pa, Prince Alexander; Tu, Mount Turu; J, Jimi; Sc, Schrader; Mm, Marum; Bb, Bena Bena; F, Finisterre; My, Menyamya; OS, Owen Stanley; Bu, Bowutu; D, Dayman; PM, Port Moresby; Ku, Kutu; De, D'Entrecasteaux; Wo, Woodlark. Former craton margin as heavy line to the south of the accreted terranes (Pigram and Davies 1987). 
R. hirsutum L.: European mountains, dry, stony situations in calcareous areas. It vicariates with the other 'Alpenrose', R. ferrugineum, which prefers acid soil and shady locations.

R. calostrotum Balf.f. \& K.Ward (the 'pygmy rhododendron with the giant flowers'), Burma, Assam, SW China, prostrate or mat-forming shrub, to $4800 \mathrm{~m}$. It has a var. calciphilum which grows on limestone. Other species range up to $4900 \mathrm{~m}$.

R. afghanicum Aitch. \& Hemsley (Afganistan/Pakistan border) creeping among rocks, usually gneiss or limestone.

Several species in Nepal-China are gregarious and form impenetrable thickets.

R. floccigerum Franchet: (Yunnan, Xizang) grows in open pine forest and on limestone cliffs and rocks.

Rhododendrons are usually plants of open, rocky, well-drained sites but several species occur in swamps ( $R$. canadense (L.) Torrey, $R$. venator Tagg) or bogs ( $R$. sanguineum Franchet). R. simsii Planchon of China and Japan to Thailand grows on hillsides, cliffs and river-banks, sometimes in places where it is submerged during the rainy season.

Dwarf, creeping species include $R$. forrestii Diels of China and Burma which is usually no more than $15 \mathrm{~cm}$ high and occurs up to $4500 \mathrm{~m}$ altitude.

According to the sample of 121/900 species in Halliday (2001), subgen. Hymenanthes is more widespread in $\mathrm{C}$ and $\mathrm{E}$ China than subgen. Rhododendron, which is mainly in the Xizang-Yunnan-Sichuan area, possibly indicating an overall vicariance between the subgenera.

A recent molecular study (Kurashige et al. 2001) found that within Rhododendron (incl. Menziesia but not Therorhodion), subgenera Hymenanthes and Tsutsusi are monophyletic, Azaleastrum and Pentanthera are polyphyletic, and Rhododendron is monophyletic (if subsect. Ledum is excluded).

Subg. Rhododendron is characterised by peltate epidermal scales but no other multicellular hairs (Stevens 1985). The subgenus is represented in Malesia by sect. Vireya only.

Nearly all the Malesian rhododendrons belong to sect. Vireya, which ranges from East Asia (subsect. Pseudovireya only), through Malesia to Queensland and the Solomon Islands and includes about a third of the species in the genus. According to Kron and Judd (1990) sect. Vireya is well-embedded in Rhododendron. Species are often locally common. Some are both widespread and common, many others are only known from a single collection.

Stevens (1985) gave a very useful overview of sect. Vireya, noting its distinctive features: geographic separation, a corolla which lacks zygomorphic markings, and seeds with tails, or at least points, at either end (subsect. Pseudovireya is variable). In addition, the capsule valves twist after dehiscence (Brown et al. 2001, citing Sleumer 1980). Other characters useful in separating sect. Vireya include the absence of a rachis (axis) in the inflorescence, the absence in the flowers of blue pigment and of spots (although a similar effect caused by the presence of scales on the corolla can be seen on a small number of species, e.g. R. variolosum), and an ovary in which the upper end tapers gradually into the style, without a marked junction.

The introduction to the vireya.net website notes that most of the species are to be found in the cool montane forests, where many species grow as epiphytes high in the trees with mosses and orchids, and are normally only seen as fallen corollas. Higher still, on more open ground, other species can be found growing terrestrially. On the Bulldog Road near Wau, gouged through the mountains and thick forest during World 
War II and now reduced to a narrow track, Black (1966) observed many Rhododendron species on the steep cuttings in the hillsides, and to a lesser extent on the road itself. The roots penetrated up to $60 \mathrm{~cm}$ in the case of small plants about $90 \mathrm{~cm}$ high, with very little surface rooting. In all the species Black observed the roots were thick and of a soft consistency, pruning shears sliding through them with ease. He wrote that these roots seem capable of storing a considerable amount of water, enabling the plants to survive on hot dry banks during dry spells. Though it was the driest part of the season, many of them were putting on new growth.

In the upper reaches of the Fatima River, Eastern Highlands, Black recorded that the vegetation was so thick on either side that they waded up the river bed, sometimes up to the armpits in swirling water. Many rhododendrons grew in the gravel and among the rocks on the banks, and in one place where the river had changed its course there were quite a number colonizing the old river bed, which appeared to be pure sand and gravel.

Section Vireya and the genus Rhododendron reach their southern limit with two species in NE Queensland at 910-1520 m (Withers 1992, Craven and Withers 1996). On the Bellenden Ker Range, R. lochiae F.Muell. sens. str. grows as a terrestrial plant hanging over the side of the rocky razor-back at the top of Mt Bellenden Ker, and on Mt. Bartle Frere it is rooted in deep cracks in or between rocky boulders. Apparently it also occurs on Bell Peak in the adjacent Malbon Thompson Range. Further north, a second species, previously identified as $R$. lochiae, is quite widespread and common in rocky areas at $910-1330 \mathrm{~m}$, growing in accumulated litter on or between rocks, and also epiphytically. (Craven, 1996, proposed a new type for $R$. lochiae so that the name would continue to apply to this widespread, well-known plant, but the proposal was rejected; L.Craven pers. comm.). It occurs around Thornton Peak, Mt Finnigan, Mount Windsor Tableland and the Main Coast Range). The largest plants grew in the forest but were invariably associated with rocks. On Mt. Finnigan this Rhododendron was found growing at the top of a large mound of rocks around the base of a rock along with the sprawling Agapetes meiniana. Although mainly growing as a terrestrial plant, on Mt. Spurgeon it mostly grows as an epiphyte on the tops of large Syzygium trees.

\section{Classification of Malesian rhododendrons}

Stevens (1985) noted that distinguishing between subsects. Pseudovireya and Siphonovireya can be difficult, but that subsects. Malayovireya, Albovireya and Phaeovireya all seem coherent and largely monophyletic. The long, narrowly tubular corolla of Solenovireya and Siphonovireya is distinctive, but it is unclear whether these two (especially former) are monophyletic. In subsect. Vireya (as subsect. Euvireya Copel. in Sleumer 1966), the separation of ser. Buxifolia from ser. Javanica is doubtfully useful, but the Papuasian members of the two together form a single group (with the New Guinea species of Stenophylla Stevens 1981), perhaps including Siphonovireya, ser. Saxifragoidea, and the West Malesian members of subsect. Vireya.

Van Royen and Kores (1982) also made changes in the composition and species order in subsect. Vireya.

Based on detailed study of the Borneo species, Argent (1982, 1985, 1988) gave a tentative classification of sect. Vireya in just two subsections:

1. Subsect. Vireya

Ser. Vireya, ser. Albovireya, ser. Phaeovireya. Incl. Solenovireya.

2. Subsect. Pseudovireya

Ser. Pseudovireya, ser. Malayovireya. Incl. Siphonovireya. 
Argent based this on four characters, as follows.

In 1., the epidermal scales have a small point-like centre, in 2. they have a large, cushion-like centre (cf. Sleumer 1966: Fig. 2).

In 1., the vegetative buds are well-developed. The bud scales are sheathing, relatively broad and thin, and characteristically persistent for some time on resting buds but quickly shed when the branch begins to grow. In 2., vegetative buds remain small and unspecialised. Bud scales are virtually absent and the young shoots develop in a naked manner. Where present, the bud-scales are slender, hardly broader than thick, and often persistent as subulate cataphylls on the elongated stems for some time after the branch has grown.

In 1., the floral bud scales (perulae of Sleumer 1966) rarely have simple hairs (if these do occur, they rarely form a fringe at the edge, and rarely have epidermal scales except at the edges) In 2., the perulae are almost always fringed with simple hairs and are often very scaly as well.

In 1., the exocarp peels irregularly from the woody 'valves' (mesocarp and endocarp) before dehiscence, while in 2. the exocarp remains firmly attached to the underlying tissues.

The four characters correlate well in the species studied, and divide Vireya into two groups. $R$. buxifolium, $R$. stapfianum, $R$. variolosum and $R$. herzogii are exceptions with incongruent character combinations and this may indicate ancient hybridism.

In Argent's scheme, Sleumer's subsections were redesignated as series with the exception of the long, white, tubular-flowered groups Solenovireya and Siphonovireya. Argent did not accept these two at any rank as they are largely based on corolla shape, which he considered a very plastic character.

According to Argent (1985), Stevens (1985) may be right that Phaeovireya should incorporate series Dendrolepidon Argent, Lamb \& Phillips, the main differences between these two being whether the scales sit on epidermal protuberances or not.

Spethmann (1987) reverted from section to subgenus Vireya (Bl.) Clarke while retaining Sleumer's seven subsections at the same rank unaltered.

Brown et al. (2001) sequenced DNA of 22 species of Malesian Rhododendron. Two clades emerged and formed a trichotomy with the outgroup (sect. Maddenia): Pseudovireya (but with a bootstrap value of only 55\%), and a clade formed from the other three subsections sampled (bootstrap value $99 \%$ ). The second is equivalent to a broadened Euvireya (including Solenovireya and Phaeovireya as paraphyletic). Rhododendron arfakianum appears as 'basal' in this second clade, which then divides into one group of five west Malesian species and one of 13 species from east Malesia, Solomons, and NE Australia.

\section{Biogeography of Rhododendron}

Sleumer and Stevens (1981) have published very useful maps showing sections and subsections of Malesian Ericaceae, but so far fewer than 20 species have been mapped (Croizat 1968, Argent 1988, van Welzen 1997, Takeuchi 2000). Sleumer's stupendous treatment (the only full treatment available) is beautifully laid out, with actual localities (not just provinces) cited. Sleumer's keyed groups indicate related recombinations of characters and putatively related species, and are indicated on the maps here by lines connecting species localities. It is the characters underlying the taxa, not the taxa per se, which are stressed in the hypocladistic approach followed here.

Other authors who have proposed new taxa and localities are cited above. 
In the maps provided here all the species but not all the varieties are shown; where they are, they are indicated with lower-case suffices. Upper-case suffices indicate new species described after Sleumer (1966-1967).

Rhododendron subsect. Pseudovireya (Clarke) Sleum. I. (Fig. 9). There are two main centres which are also important for the genus as a whole: north Sumatra/Peninsular Malaysia (from here connections are also possible with Madagascar, Burma etc.) and western New Guinea. East and West Malesian taxa are connected via Mount Bonthain (= Mt Lompobattang) in SW Sulawesi. The group is notably absent from Kinabalu and the Philippines, in contrast with the next. Doormantop in Irian Jaya (Rouffaer terrane) is associated with major disjunction to Sumatra-Java. Within New Guinea there is a disjunction between the Vogelkop and the Owen Stanley terrane (Mt Dickson/Bakaia). Concentric distributions around Mt. Carstensz, Doormantop and Oranje Mts. possibly indicate evolution around regressing seas.

Rhododendron subsect. Pseudovireya II. (Fig. 10). A Sumatra/Peninsular Malaysia group (spp. 14-16) is sister to the rest and an Aceh - Snow Mountains (Carstensz-Oranje Mts.) track again defines the group and the disjunction sp. 17 - 18 (cf. podocarps etc. listed below). East and west Malesia are connected north of the last group, and in Sulawesi are centred on Latimodjong. 19: R. ericoides grows in subalpine shrubland of Kinabalu with Leptospermum and Dacrydium as a $3 \mathrm{~m}$ high shrub, and ranges right to the summit in rock cracks where it is ultimately just 15 centimetres high.

Rhododendron subsect. Siphonovireya Sleum. (Fig. 11). Sp. 32: (R. incommodum Sleum., the name referring to its uncertain position) crosses the great Markham Valley, but stops at Okapa. This is inexplicable by current geography, but is closely correlated with the former margin of the Australian craton (this feature is shown here on all the New Guinea maps). The remaining five local endemics are all on the craton. Although the group is most diverse in western New Guinea, it does not occur outboard of the craton margin in the Vogelkop. Stevens (1976) viewed the placement of 32: R. incommodum (1830-1950 m) in Siphonovireya with suspicion because of the flower, which is identical to that of 250: R. longiflorum (Borneo-Sumatra, sea-level to $1500 \mathrm{~m}$ ).

Rhododendron subsect. Phaeovireya Sleum. I. (Fig. 12). This ranges: Doormantop/Oranje Mts. - Latimodjong. 41: R. hooglandii has a stronghold on Kubor Mountains, south of the craton margin, and on Mount Kerigomna (more or less on the margin), but is notably absent from Mt. Wilhelm (north of the craton margin). It is closely allied to 41A., also restricted to the craton.

Rhododendron subsect. Phaeovireya II. (Fig. 13). Latimodjong - Upper Sepik (Dimaie terrane). The Sulawesi-New Guinea disjunction is involved here with accreted terranes. Like Siphonovireya, the group is notably absent from the Vogelkop and is more diverse in PNG (four species) than in Irian Jaya (one species).

Rhododendron subsect. Phaeovireya III. (Fig. 14). There are two disjunctions between the accreted terranes of the northern Vogelkop (especially Arfak terrane) and those of PNG: one to sp. 67 on Lagaip limestone (on the craton but close to the margin), and one to sp. 66 on Mt Kaindi (Owen Stanley terrane).

Overall, Phaeovireya masses more or less evenly in Irian Jaya and PNG, which is unusual in Rhododendron. Subsect. Solenovireya is even more unusual as it has most species in PNG. 


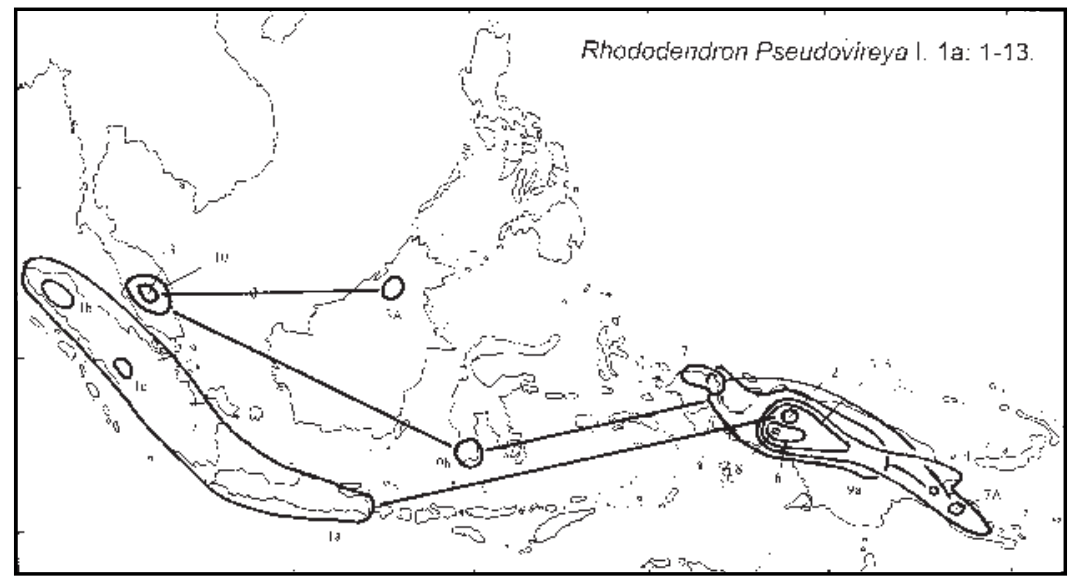

Fig. 9. Rhododendron subsect. Pseudovireya I. For sp. 11, see 94. For sp. 12., see 183.

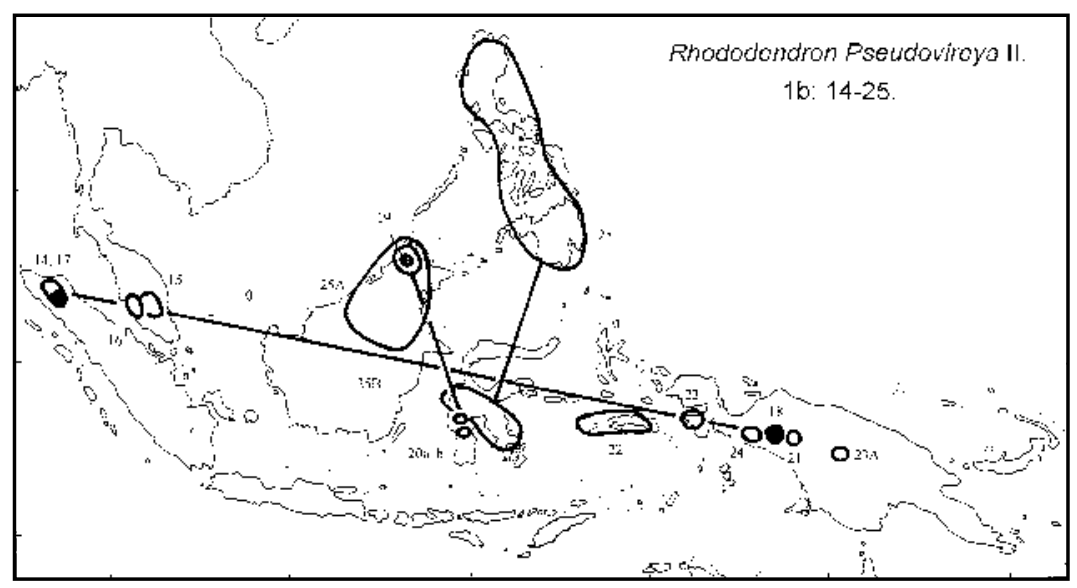

Fig. 10. R. subsect. Pseudovireya II. 25A R. borneensis (J.J. Sm.) Argent, Lamb \& Phillips (three varieties) and 25B R. cuneifolium Stapf (two varieties) are split off from 25 R. quadrasiamum sensu Sleumer (Argent, Lamb and Philips 1984).

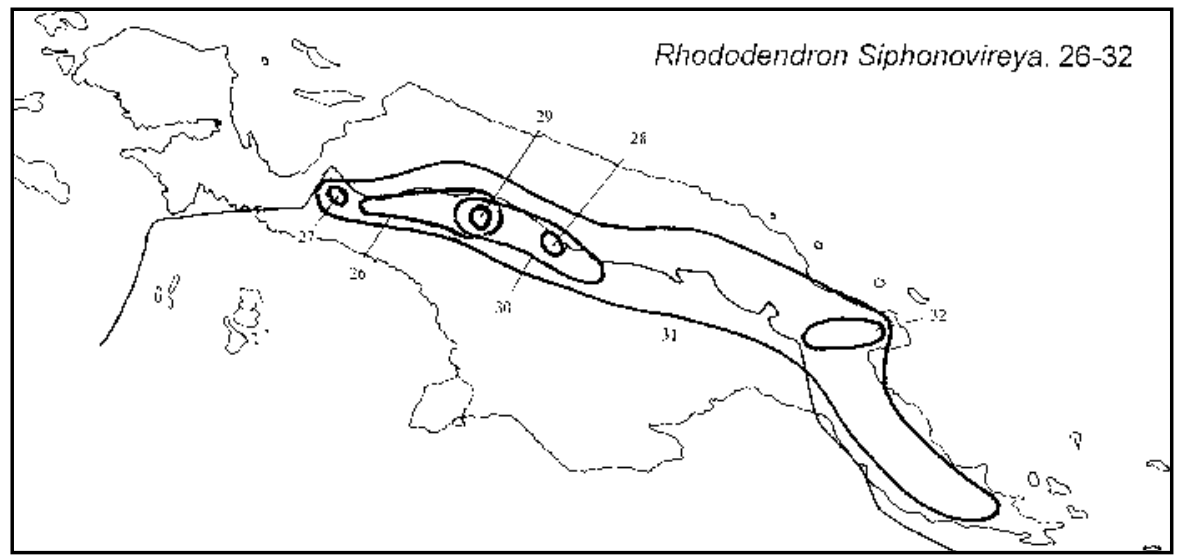

Fig. 11. Rhododendron subsect. Siphonovireya. 


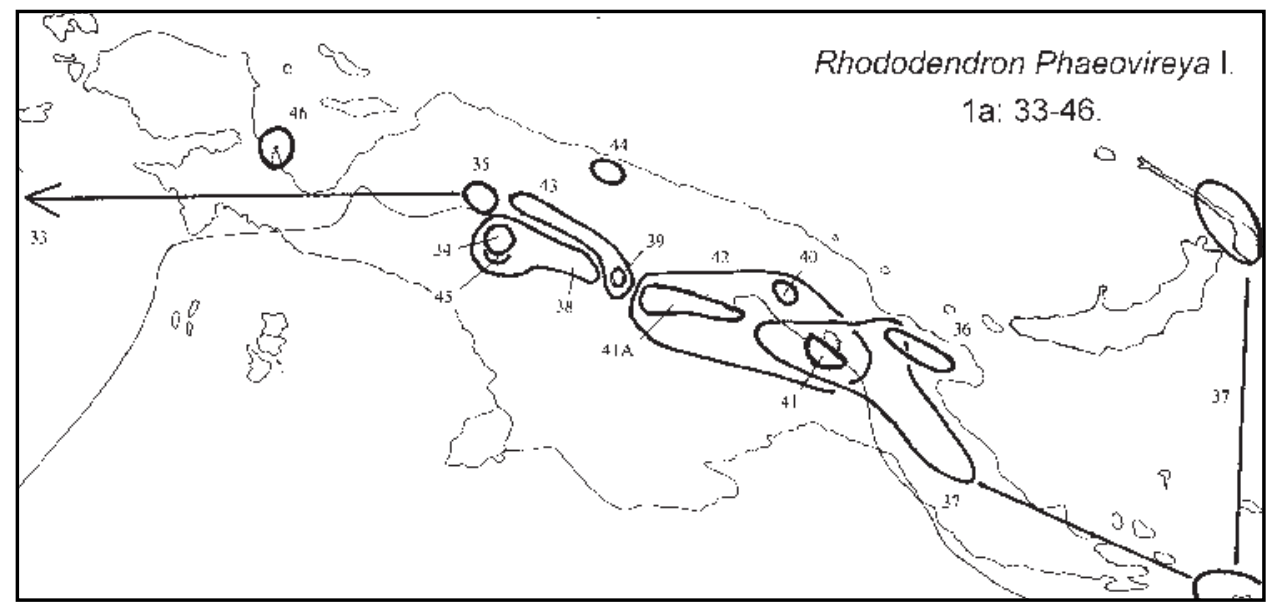

Fig. 12. Rhododendron subsect. Phaeovireya I.

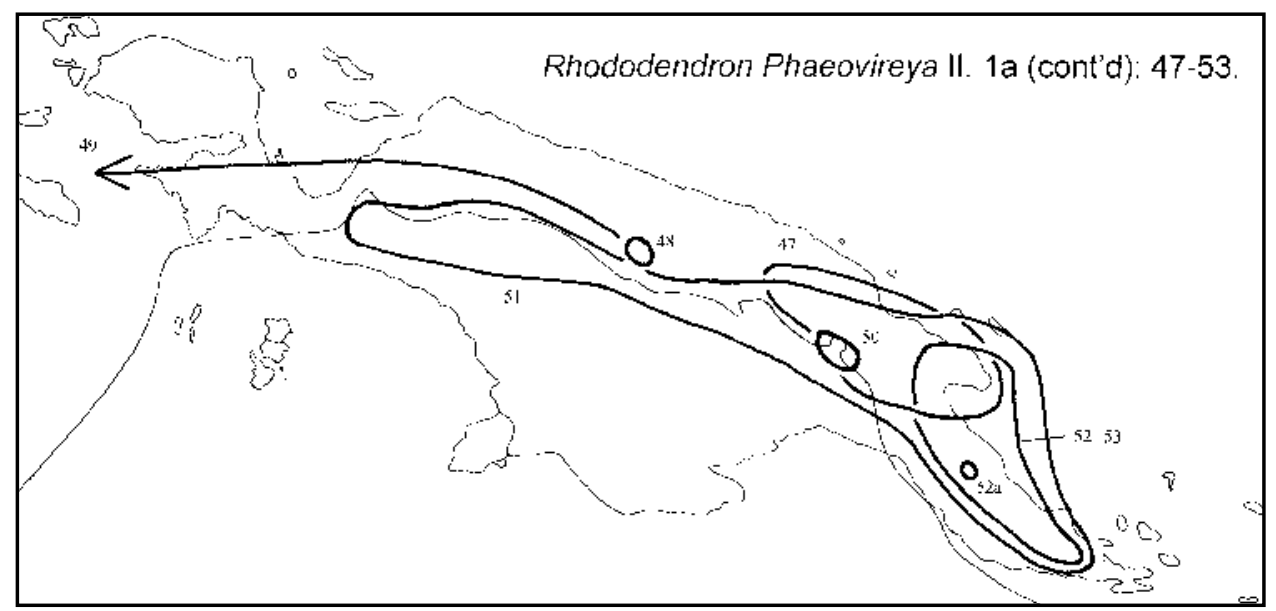

Fig. 13. Rhododendron subsect. Phaeovireya II. 52 includes 53 as a variety (Argent 1995).

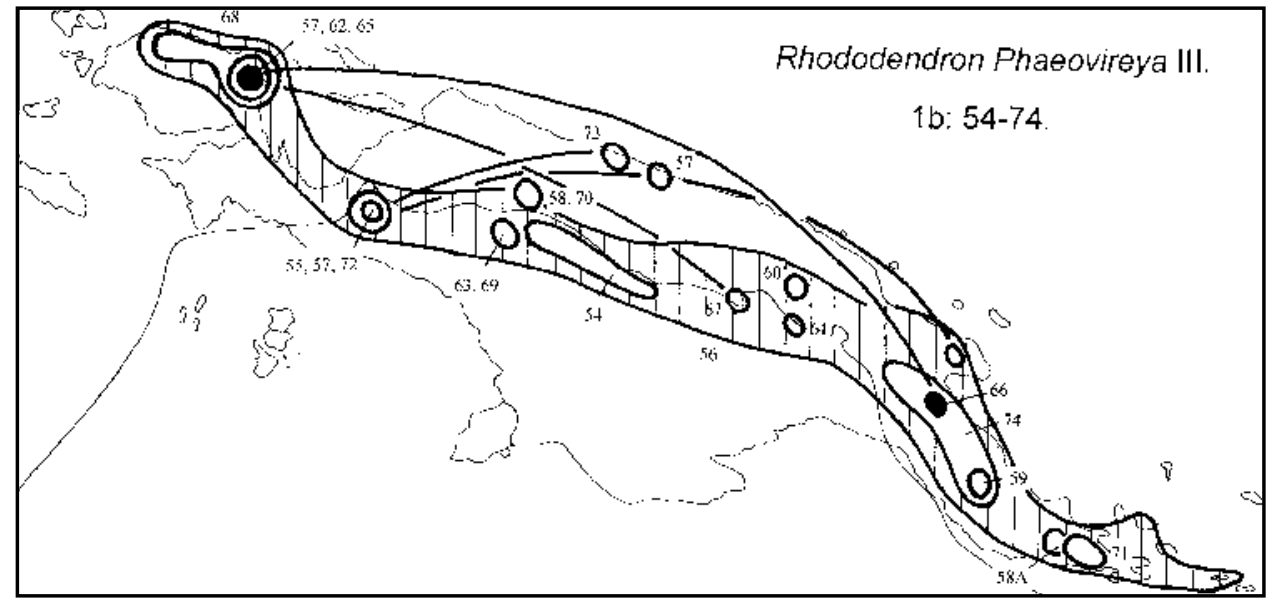

Fig. 14. Rhododendron subsect. Phaeovireya III. 56 includes 57 as a variety (Argent 1995). 
Rhododendron subsect. Malayovireya Sleum. (Fig. 15). There is a strong massing on northern Borneo. The group was placed with Euvireya, Albovireya and Solenovireya by Sleumer (1966), but with Pseudovireya by Argent (1985).

Rhododendron subsect. Albovireya Sleum. (Fig. 16). Latimodjong is central in the distribution and is the most diverse area. There are three separate connections between here and New Guinea, with the Vogelkop, the PNG mountains, and Mts. Albert Edward/Scratchley/Victoria, respectively. The group is absent from Borneo. The parallel arcs in SW Sumatra/W Java are noteworthy, as are two identical disjunctions: Snow Mts - Mt Victoria (Owen Stanley terrane) (spp. 95-96, and 101-102).

Rhododendron subsect. Solenovireya Copel. I. (Fig. 17). There is a Snow Mountains - Mt Victoria disjunction, as in the last. The Kinabalu-Vogelkop disjunction here is vicariant with the disjunct arcs Philippines - New Guinea and Sulawesi - New Guinea in the next map, giving three parallel tracks.

Rhododendron subsect. Solenovireya II. (Fig. 18). The New Guinea range comprises three parallel arcs:

* N Sumatra/Peninsular Malaysia - S Philippines (Palawan, Mindanao) - Lae/New Britain. The sister group is in $\mathrm{N}$ and $\mathrm{W}$ Borneo.

* CE Borneo (Mt. Kemul) - Sulawesi - Mt Carstensz (cf. Buxifolia IV).

* Disjunction within New Guinea between terranes in the far west (Tamrau/Tohkiri/ Nettoti Ranges and Wissel Lakes) and the far east (Goodenough Island). This last island is D'Entrecasteaux terrane, which may be an easterly extension of Owen Stanley terrane (Pigram and Davies 1987). The substantial massing on the Milne Bay mountains (Dayman, Simpson and Suckling) is unique in Ericaceae. In Vaccinium sect. Bracteata XI and Styphelia this node is connected with the Philippines and Marianas Is. respectively.

The Borneo group (130-131, 131A, 131B) forms an arc between the Meratus Mts. and Kinabalu.

Species 133 has subspecies in New Britain and Lakekamu, separated by the New Guinea orogen.

Solenovireya is unique in Rhododendron as it has more species in PNG (13) than in Irian Jaya (7).

Rhododendron subsect. Vireya (= subsect. Euvireya Copel.):

Like Diplycosia, below, this group virtually defines Malesia, with slight extensions to southern Vietnam and the Solomons, and absences in Timor and the northern Moluccas.

Rhododendron ser. Linnaeoidea Sleum. (Fig. 19). The concentric distributions on Oranje Mts. as in Pseudovireya I could be the result of evolution around the margins of shrinking seas. Nine of the 11 species are in Irian Jaya, all but one on the craton. There are only three in PNG, a pattern like Siphonovireya.Sp. 137 is disjunct between Mt. Carstensz and Bismarck Range NW of Mt. Wilhelm (Takeuchi 1999a). Craven (1980) originally listed sp. 137A from Star Mts. to Wharton Range but van Royen and Kores (1982) list it east to New Britain.

Rhododendron ser. Saxifragoidea Sleum. (Fig. 20). This occurs only along the northern rim of the craton, from Mt. Carstensz to Mt. Giluwe.

Rhododendron ser. Taxifolia Sleum. (not mapped). Only on Luzon (Mts. Pulog and Tabayoc). This group is sister to the next. 


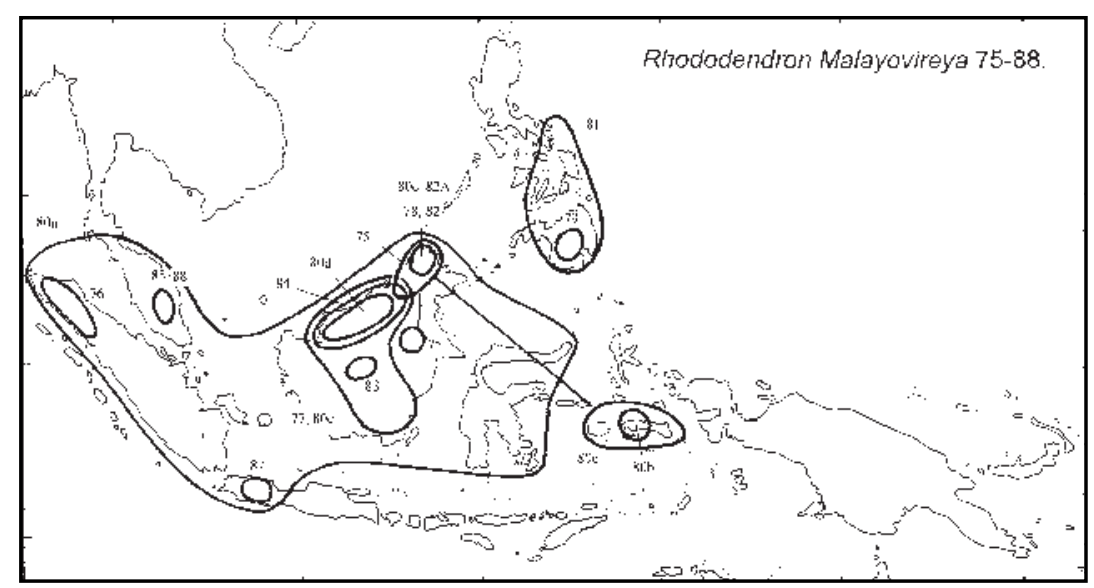

Fig. 15. Rhododendron subsect. Malayovireya.

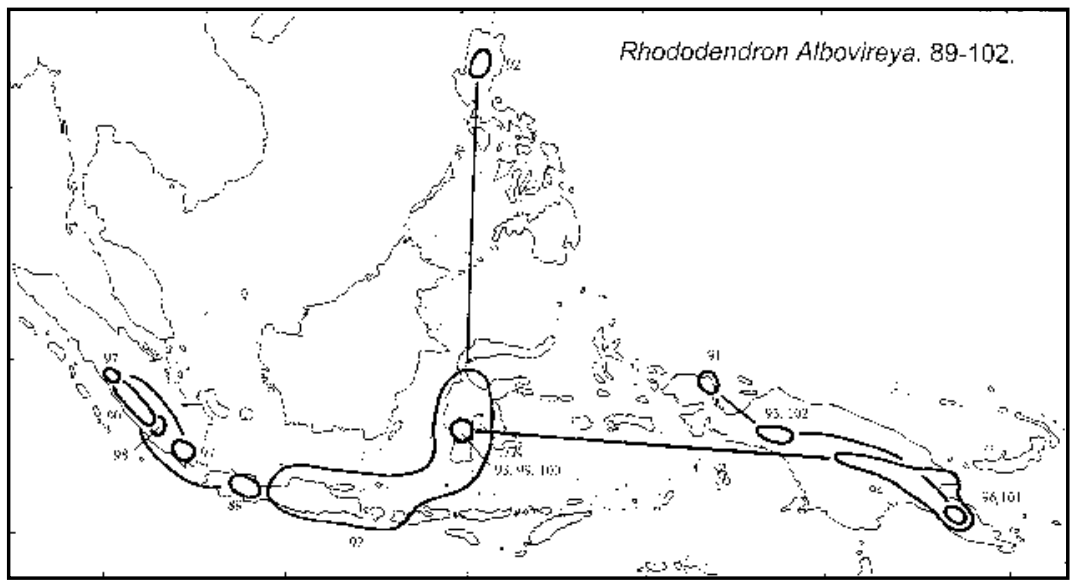

Fig. 16. Rhododendron subsect. Albovireya.

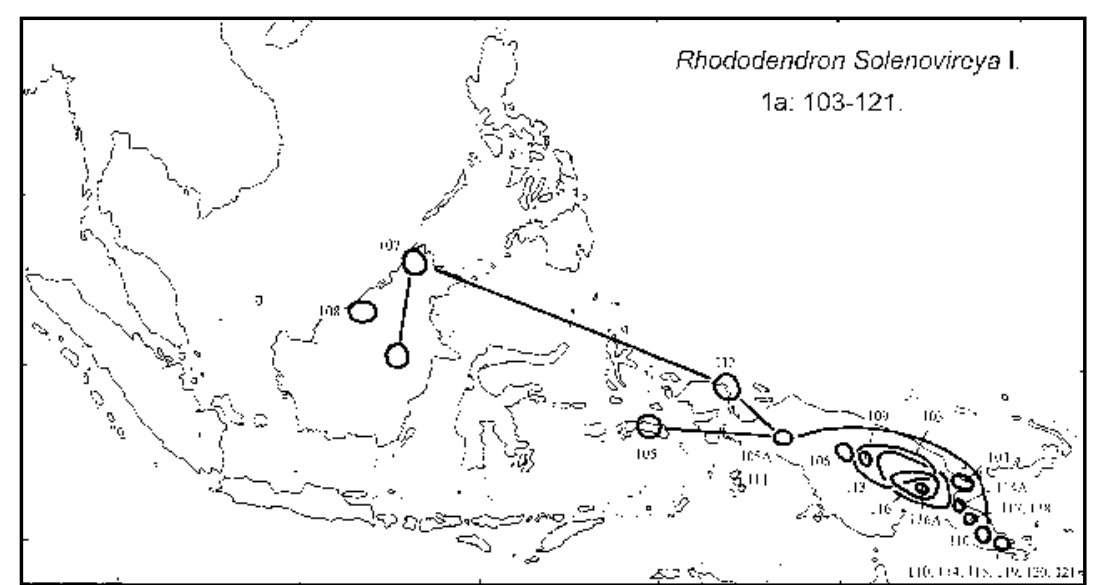

Fig. 17. Rhododendron subsect. Solenovireya I. 


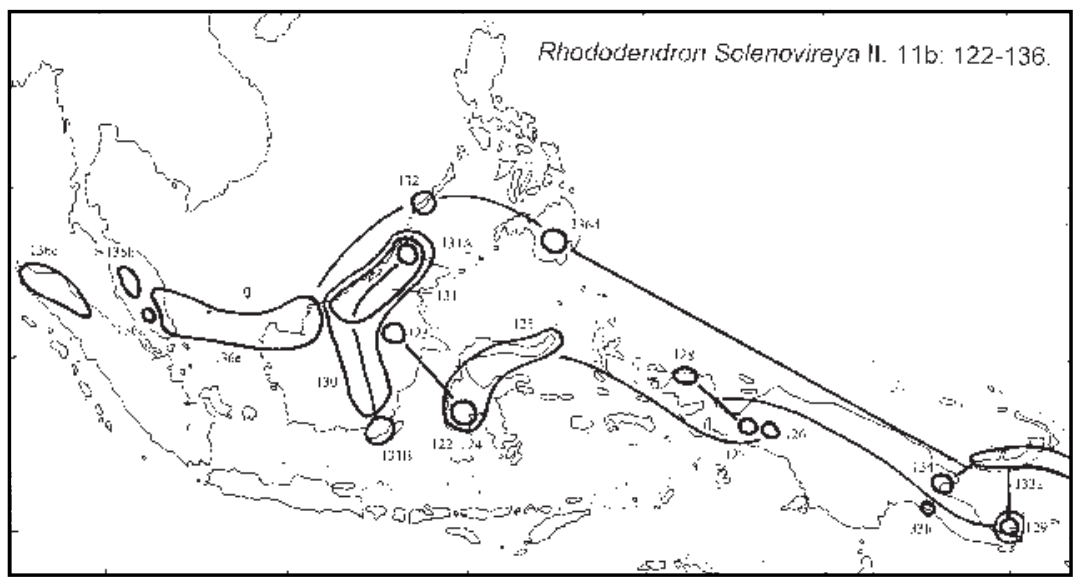

Fig. 18. Rhododendron subsect. Solenovireya II. 135 is included in 133. 133a is R. loranthiflorum var. lakekamuensis Takeuchi.

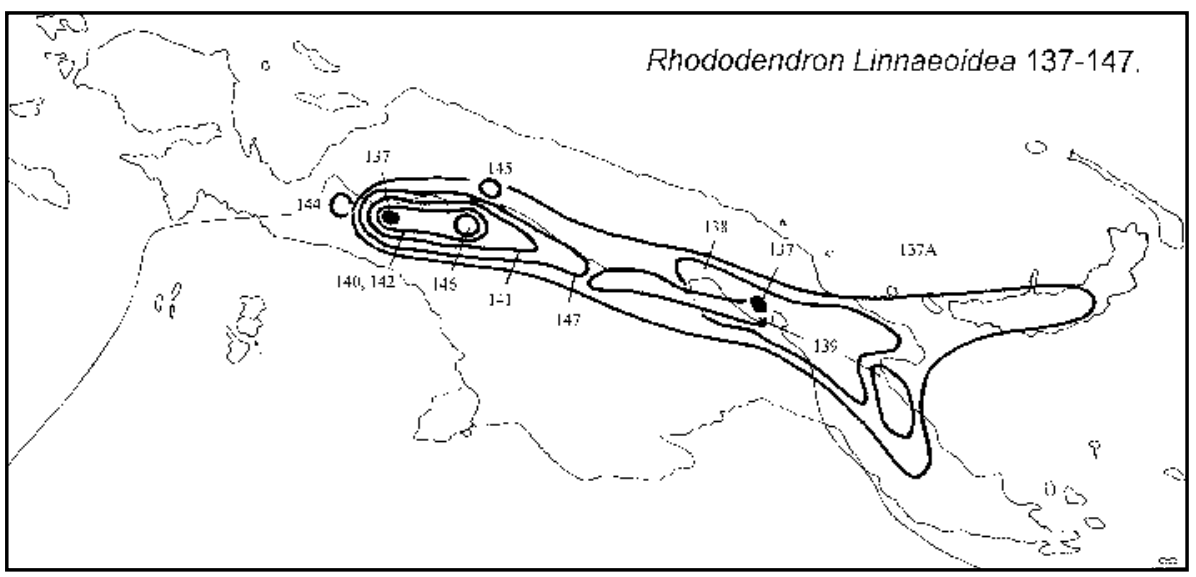

Fig. 19. Rhododendron ser. Linnaeoidea.

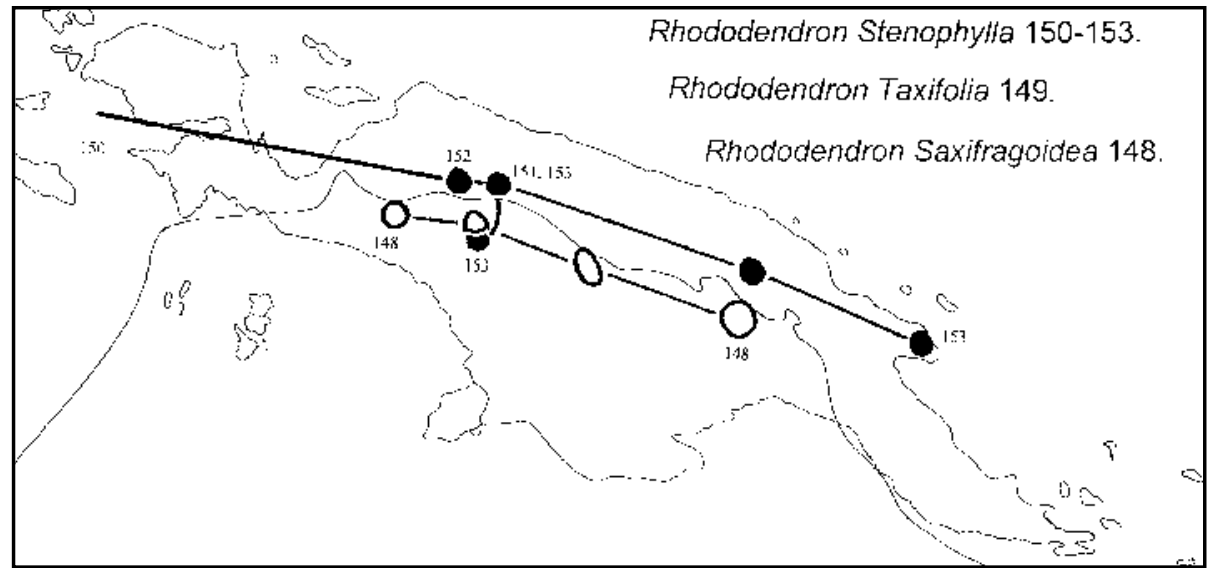

Fig. 20. Rhododendron ser. Saxifragoidea, R. ser. Stenophylla, R. ser. Taxifolia. 
Rhododendron ser. Stenophylla Sleum. (Fig. 20). This occurs north of the craton only, except for a single record at Perameles Bivaque (Went Mts.) south of Mt. Wilhelmina. The group is disjunct in Borneo. Stevens (1976) suggested that the New Guinea species are probably allied instead with Papuasian members of Ser. Javanica and Buxifolia, but did not indicate a position for the Borneo species.

Rhododendron ser. Citrina Sleum. (Fig. 21). This comprises a single species of Sumatra and Java, keyed as sister to the remaining 122 Malesian Rhododendron species.

Rhododendron ser. Buxifolia Sleum. I. (Fig. 22). As in the last, a Sumatra species (155, Gajo Lands) is sister to the rest. The three New Guinea tracks (Luzon -Waigeo; Latimodjong - PNG mountains; Peninsular Malaysia - Snow Mts.) show New Guinea deconstructed into an amalgamation of island arcs and other terranes (cf. subsect. Solenovireya II, ser. Saxifragoidea/ser. Stenophylla). The map of sp. 162 is reproduced from Argent (1988).

Rhododendron ser. Buxifolia II. (Fig. 23). The Irian Jaya species is south of the former craton margin, sp. 173A tracks the margin. Both these are related to E and C Sulawesi species, rather than to the PNG species 170 and 171 which are outboard of the craton.

Rhododendron ser. Buxifolia III. (Fig. 24). This comprises a Vogelkop species sister to an outer arc of four species: Aceh (Gajo Lands) - Palawan (Mt Mantalingahan, cf. Solenovireya) - Owen Stanley Mts. This and the next map show three vicariant arcs.

Rhododendron ser. Buxifolia IV. (Fig. 25.). The Aceh (Gajo Lands) species is sister to the rest, and there are precedents for a direct Aceh-Kinabalu connection (e.g. Potentilla borneensis (Stapf) Kalkman (Rosa.), known only from the two localities and related to species of the Himalayas/Taiwan on one hand, and of Sulawesi/New Guinea on the other (Kalkman 1993)). There are two other significant disjunctions: 1. Kinabalu Oranje Mts. (craton), and 2. Latimodjong - Oranje Mts.

Rhododendron ser. Javanica Sleum. I. (Fig. 26). This group is in Borneo (Sabah-Sarawak) and New Guinea, mainly on the craton, and absent from the Vogelkop, Huon Peninsula, and Milne Bay. The Nassau/Oranje/Treub Mts. - Wilhelm disjunction in 202 resembles differentiation in Drimys piperita Hook.f. (Winter.) discussed below. The NW Borneo - W New Guinea disjunction is seen in alpines such as Kelleria Endl. (Thymel.) (Fig. 127) and lowland plants such as Dactylocladus (Oliv.) (Crypteron.) (van Beusekom-Osinga 1977) (although in both of these the W New Guinea records are on Rouffaer terrane, rather than at Mts. Carstensz/Wilhelmina like the Rhododendrons). Dactylocladus forms trees up to $40 \mathrm{~m}$ tall with pneumatophores, and is one of the most characteristic taxa in the lowland peat swamp forests of $\mathrm{W}$ Borneo. Pollen has been reported in a Miocene deposit in Brunei with the same associates as to-day. As van Beusekom-Osinga noted, 'It is remarkable that whereas this type of peat forest ranged unbrokenly at least from the Miocene to the Present, Dactylocladus is not found in Sumatra and Malaya ...'. The only other record of the genus is in New Guinea, in peat forest along the Rouffaer R. where it is 'the only large tree in this forest type'. Van Beusekom-Osinga (1977) argued logically that the absence of peat forest between New Guinea and Borneo is no explanation of the disjunction, as the same gap occurs in taxa such as Koompassia (Legum. - Caesalpin.) which are not peat-dwellers. 


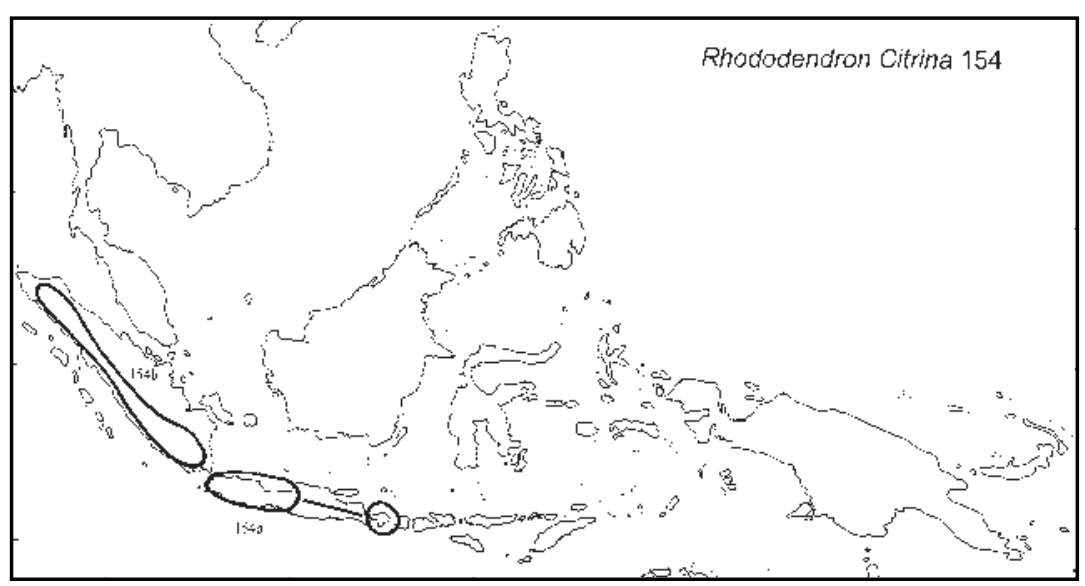

Fig. 21. Rhododendron ser. Citrina.

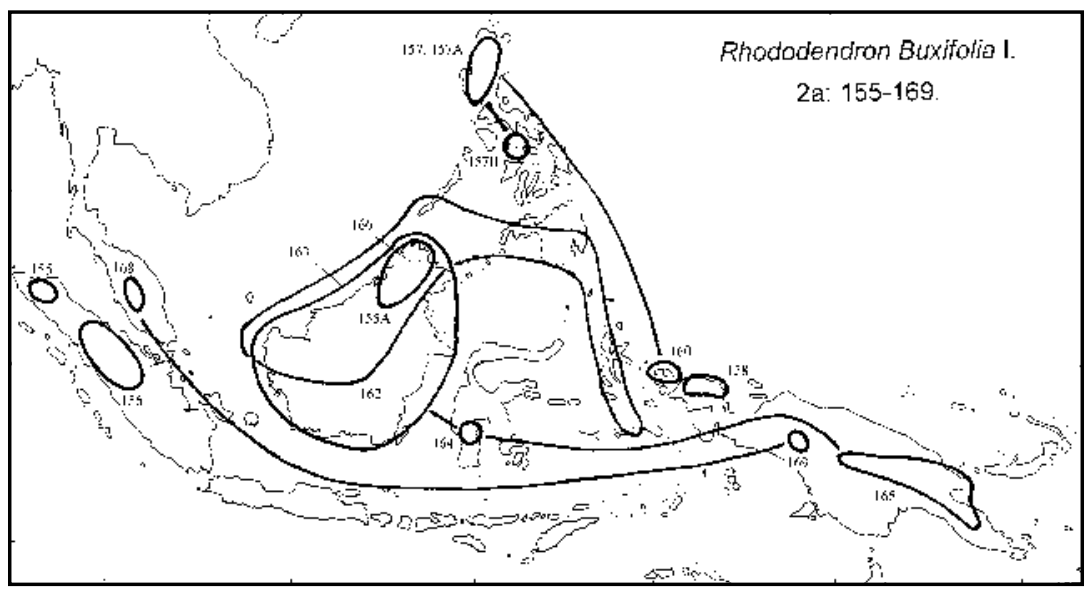

Fig. 22. Rhododendron ser. Buxifolia I. 159 is included in 170, 161 and 167 are hybrids. Distribution of 162 is from Argent $(1988,1998)$.

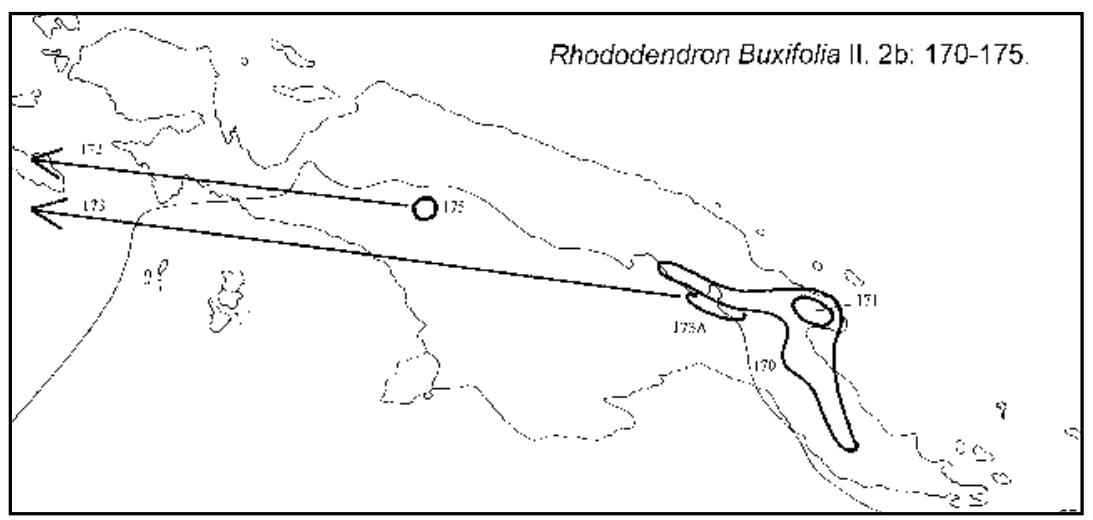

Fig 23. Rhododendron ser. Buxifolia II. 172 is also in C Sulawesi (Kambuno). 173 is in E-C Sulawesi: Lumut. 173A is 'to be inserted near 172 and 173', but is 'markedly different' (Sleumer 1973). 


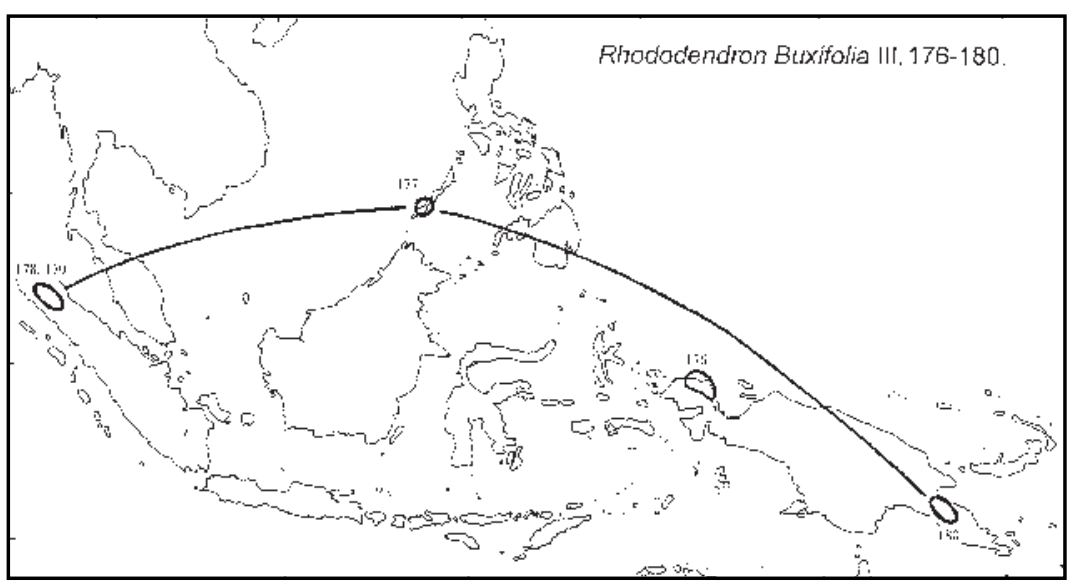

Fig. 24. Rhododendron ser. Buxifolia III. van Royen and Kores (1982) transferred 180 to ser. Javanica, but did not refer to the other species mapped here.

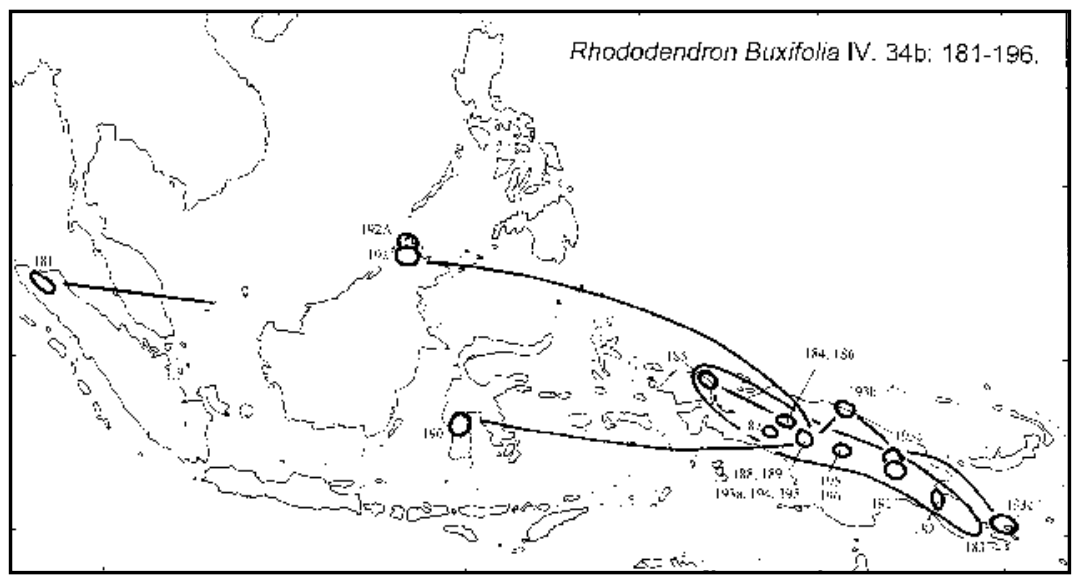

Fig. 25. Rhododendron ser. Buxifolia IV.

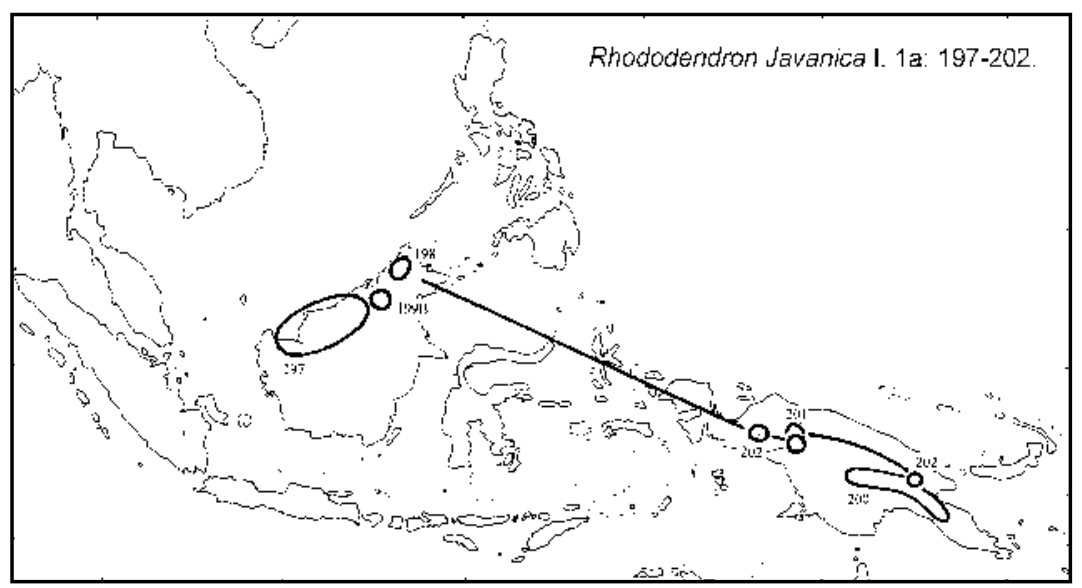

Fig. 26. Rhododendron ser. Javanica I. 199 is a hybrid. 
Rhododendron ser. Javanica II. (Fig. 27). This group surrounds Borneo from the east. In PNG the group is only on accreted terranes, with sp. 204 on Finisterre terrane and 206 on Mt Obree, by the contact of Owen Stanley and Dayman terrane. (The large block of Dayman terrane lying east of Mt. Kenive(= Nisbet) and Mt. Obree (Pigram and Davies 1987) is shown on Bain et al.'s (1972) map as Owen Stanley terrane). Both PNG species are related to craton species in Irian Jaya (cf. the honeyeater Macgregoria etc.). However, the two PNG species are keyed together in Sleumer's key; instead there are two parallel arcs: NE Sulawesi - Wichmann Mts. - Huon Peninsula, and S Moluccas - Balim Valley/Mt Goliath - Mt Obree.

Rhododendron ser. Javanica III. (Fig. 28). Here a group on N Sumatra - N Philippines - Moluccas (214-218, hatched) surrounds Borneo, as does the group 219-225 (widespaced hatching) except for a record at Mt Kemul, central E Borneo. Spp. 219-225 are sister to 226-227. The CW Sumatra (Kerintji, 226) - Borneo (227) connection is also seen in the mangrove $R$. brookeanum (276). Sp. 268: $R$. culminicolum var. angiense occurs east to the Star Mts.; plants on New Ireland (Hans Meyer Ra.) are an undescribed variety (Johns and Argent 1995) which keys out to var. angiense.

Rhododendron ser. Javanica IV. (Fig. 29). The Latimodjong - New Guinea distribution is like that of Phaeovireya I and II. Sp. 229 holds an outer arc in PNG: Torricelli Mts. (Torricelli terrane) - Maboro Range (not located) - Waria R. (Bowutu or Owen Stanley terrane).

Rhododendron ser. Javanica V. (Fig. 30). 250: R. longiflorum occurs in the Mentawei Islands, W Sumatra, Riouw Pocket (Bangka I., where there is an endemic variety; Karimata Is.) and Borneo, where it is widespread but apparently not on Kinabalu (Sleumer 1973) (cf. Costera, Vaccinium sect. Rigiolepis). It is an epiphyte in primary and secondary forest and mangrove, and is terrestrial on rocks, in kerangas and in poor forest in stagnant water. It is keyed with 244-249 of New Guinea and the Solomon Islands (with a related species in NE Queensland). As suggested above, this is possibly the result of an Indian Ocean group occupying Malesia in an ancestral stage, and for the most part being largely uplifted in the New Guinea orogen - van Steenis's (1978b) observations on uplifted mangroves can be applied to the whole flora. The Arfak Mts - Mt. Dayman disjunction (247-248) is an outer arc parallel to the Snow Mts - Owen Stanley Mts seen in groups like Albovireya and Solenovireya I. spp. 237-238 (Cyclops terrane - Bismarck Mts) are the largest-flowered rhododendrons, both occur only on accreted terrane.

Rhododendron ser. Javanica VI. (Fig. 31). There are two arcs: Philippines - accreted terranes of PNG (Jimi Valley - Jimi terrane; Bulolo/Wau - Owen Stanley terrane); and New Guinea - southern Moluccas.

Rhododendron ser. Javanica VII. (Fig. 32). The double tracks here again indicate the hybrid nature of Borneo, Sulawesi and New Guinea. 


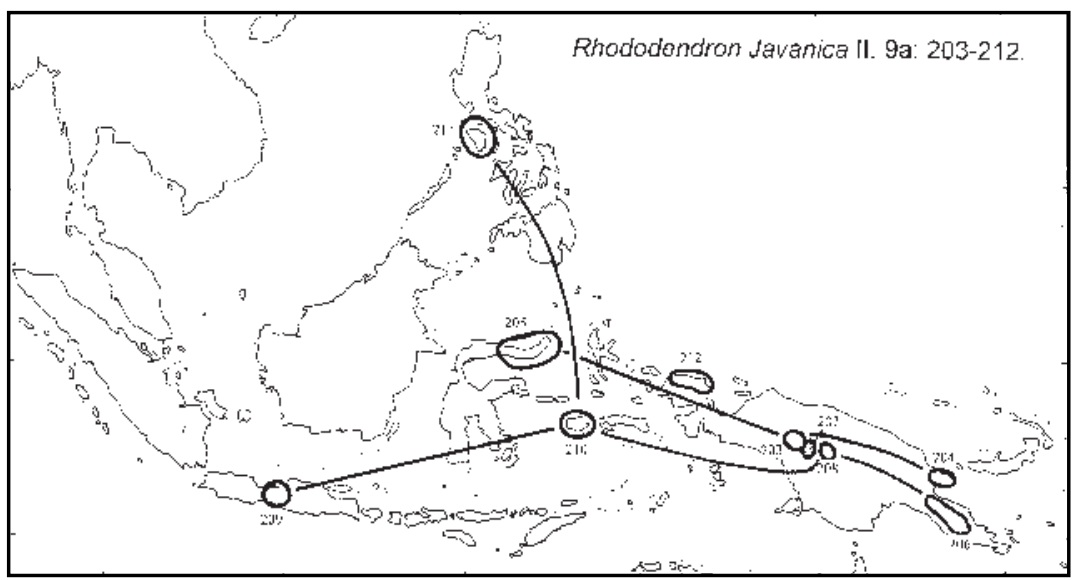

Fig. 27. Rhododendron ser. Javanica II.

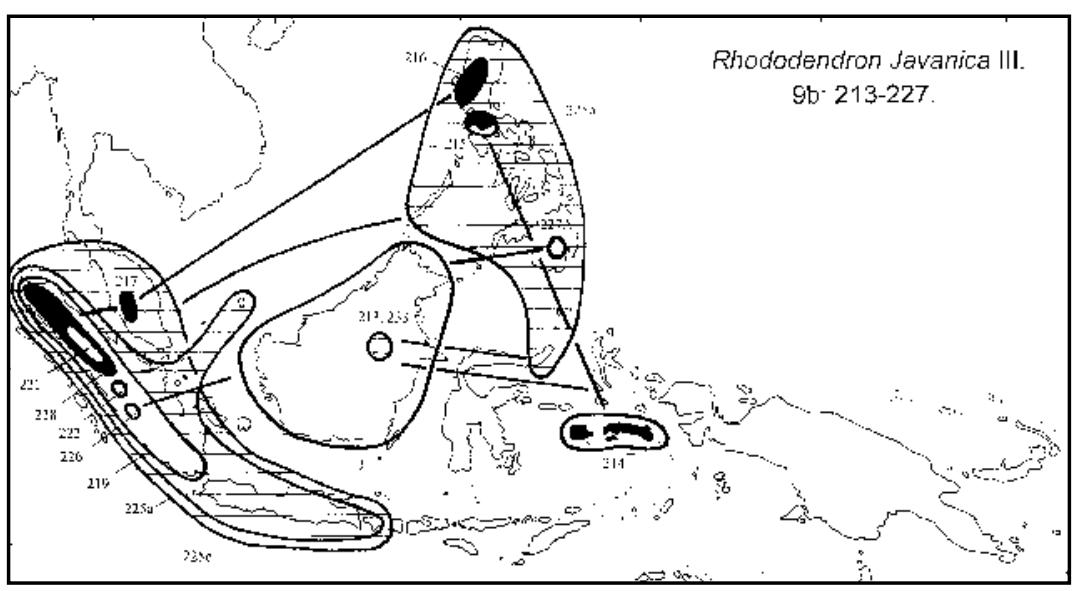

Fig. 28. Rhododendron Ser. Javanica III. 220 is included in 227. Taxon 224 is a variety of 276.

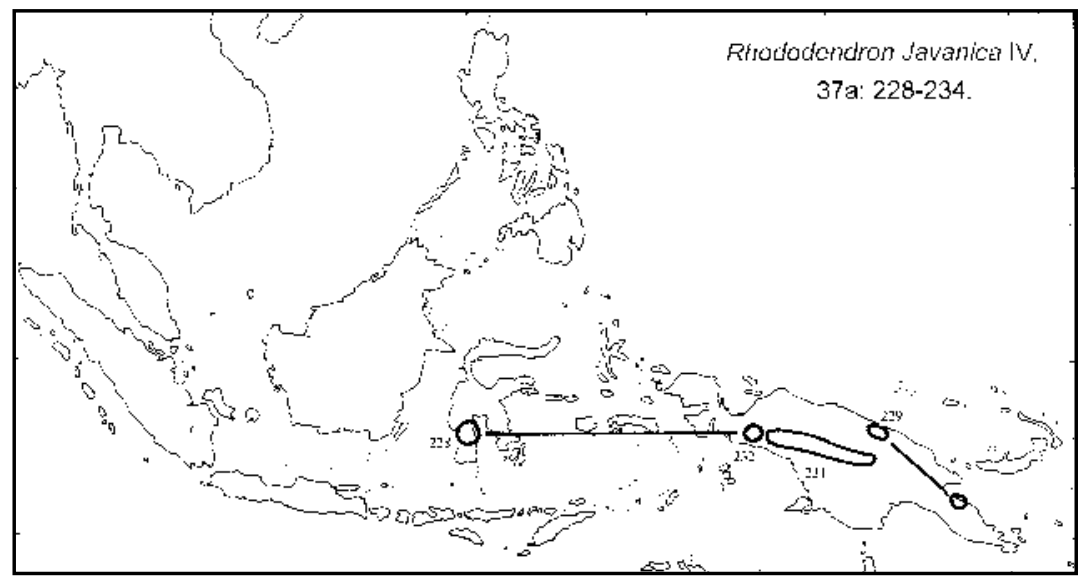

Fig. 29. Rhododendron ser. Javanica IV. Sp. 230 is recorded only from 'New Guinea' and has not been mapped. 233 and 234 are included in 250. 


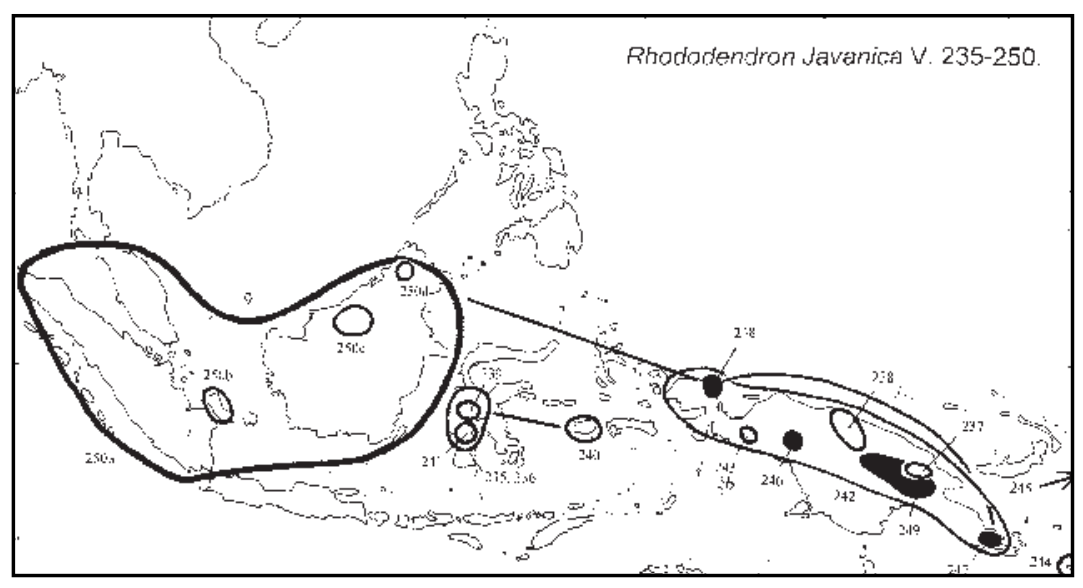

Fig. 30. Rhododendron ser. Javanica V. Sp. 244 of Sudest I. is closest to the Queensland species. Within the Malesian species it is keyed with 245 of Bougainville, New Georgia and Guadalcanal (Sleumer 1966).

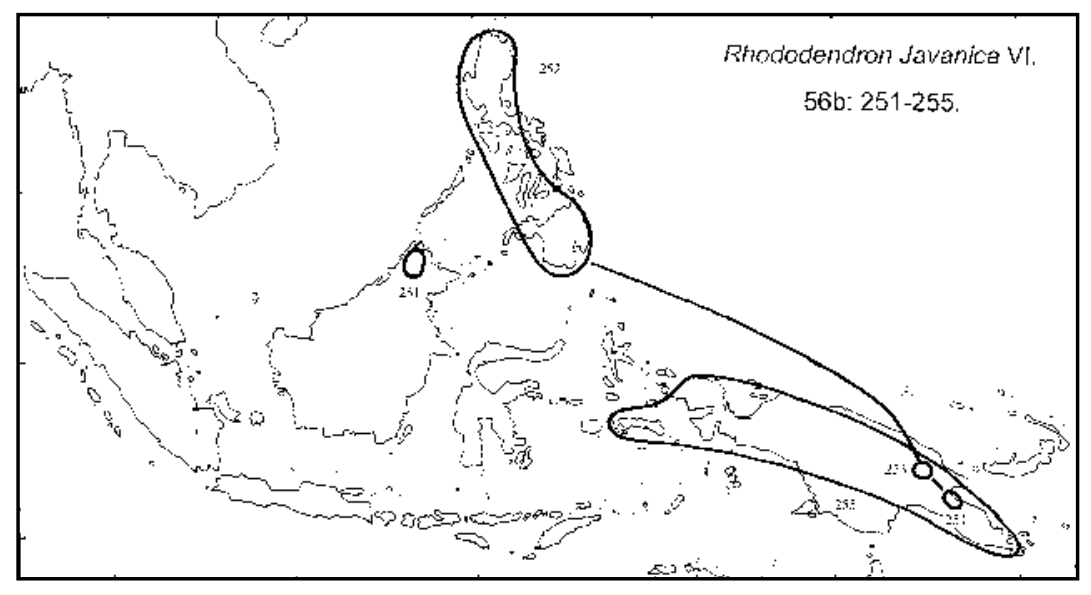

Fig. 31. Rhododendron ser. Javanica VI. Argent (1992) suggested 251 might be better placed with 198.

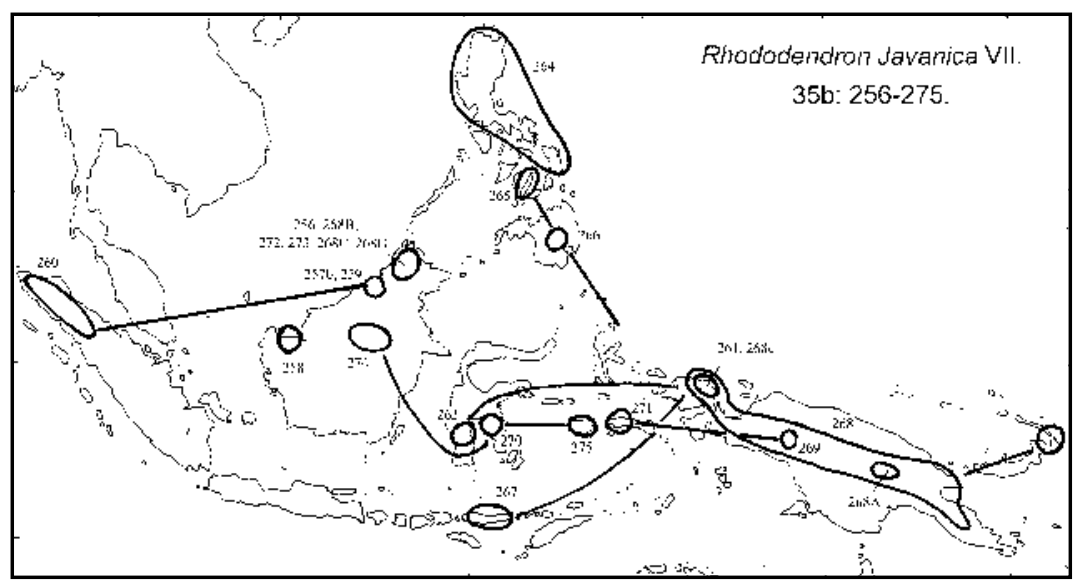

Fig. 32. Rhododendron ser. Javanica VII. 262 is a hybrid. 
276. Rhododendron brookeanum, (Fig. 33), recorded from mangrove, is in CW Sumatra and widespread in Borneo (cf. 227). It is shown separately here for convenience, but belongs with Javanica VII with which it is largely vicariant. However, Argent (1988) described material from E. Sabah which shows remarkable similarity to the Javan form of 225: R. javanicum and is very distinct from most other forms of $R$. brookeanum in Sabah. Argent had earlier synonymised these two, but later accepted them as distinct. However, recent acquisition of new material from Sumatra 'throws back all the old problems of making distinctions of more than one character that do not have exceptions in wide ranging low altitude species'. The fluidity of the situation in these widespread, low altitude W Malesian mangrove/volcano plants perhaps resembles that of the ancestral complex out of which the large diversity of montane, more or less local endemics in E Malesia 'precipitated'.

The following three Asian subgenera occur only at the northern and western margins of Malesia:

Rhododendron subgen. Hymenanthes (B1.) K.Koch (Fig. 34). N Sumatra/Peninsular Malaysia.

Rhododendron subgen. Tsutsutsi (G.Don) Pojarkova (Fig. 34). Luzon.

Rhododendron subgen. Azaleastrum Planch. (Fig. 35). Peninsular Malaysia.

\section{Monotropoideae}

Monotropoideae is not mapped here. Andresia Sleum., Monotropastrum Andres and Pyrola L. (the latter formerly in Pyroloideae) each have one species in Malesia: in Peninsular Malaysia, N Sumatra (Tapanuli, Gajo Lands), and Peninsular Malaysia respectively.

Lyonia Nutt. was treated by Sleumer with Pyrola, but the DNA studies cited above support a position with Vaccinioideae. It is in Malesia only in Peninsular Malaysia.

Pernettyopsis King \& Gamble. (Fig. 36). Peninsular Malaysia - N Sarawak (Mt Mulu, Argent (1982)). It is keyed by Sleumer (1966) with Gaultheria and Diplycosia.

Gaultheria L. I. (Fig. 36). Gaultheria has Malesian centres of diversity in Sumatra and New Guinea and only one species out of 24 in Borneo. This is vicariant with its near relative Diplycosia which has almost half its 97 species in Borneo, and secondary centres in Sulawesi and New Guinea. Middleton (1991) revised the infrageneric classification of Gaultheria, which occurs in east Asia, Australasia and the Americas. Four of the ten sections in the genus are represented in Malesia.

G. sect. Brossaeopsis Airy Shaw comprises three series. One is monospecific in the Himalayas. Ser. Dumicolae Airy Shaw occurs in the Himalayas, Yunnan (G. notabilis) and disjunct in Sumatra (spp. 7-9). Ser. Atjehenses Airy Shaw comprises spp. 2 and 3 from Sumatra and Java. Sleumer wrote that sp. 2 is 'remarkably near' G. notabilis and the Himalaya/Yunnan - Sumatra disjunction is notable. The section is closest to plants of the Andes.

G. sect. Monoanthemona Middleton (wide hatching on map) is a trans-Pacific group comprising three series. The first is monospecific for 10: G. nummularioides: Himalayas to W Szechuan and Upper Burma, disjunct to Sumatra, Java and Bali. This is 'difficult to separate' from ser. Antipodae, comprising 11: G. mundula of New Guinea, and plants of Tasmania, New Zealand and western South America. The last series is in SE Brazil. 
Gaultheria II. (Fig. 37). North Sumatra - Peninsular Malaysia - Vogelkop. Again, Borneo is hardly involved in this pattern, and has no endemics.

G. sect. Brossaea (L.) Middleton, by far the largest in the genus, ranges from Asia to Australasia and America. The Malesian species 1, 4-6 (see Gaultheria I) and 12-22 were treated here by Middleton in two series which show little biogeographic separation. The disjunction between the Vogelkop (16) and 17-19 may be to Peninsular Malaysia $(17,19)$ or Sumatra/Java $(18)$.

G. sect. Chiogenopsis Middleton includes 23: G. novaguineensis (New Guinea) and 24: G. pernettyoides (Gajo Lands) (both fine hatching on map), both allied with Himalayan/Chinese species (cf. Pseudovireya II, Buxifolia I). The section is elsewhere known from Japan and North America.

Diplycosia Bl. I. (Fig. 38). There are two parallel arcs: Luzon - Vogelkop (Arfak terrane) - April R. (Sepik terrane); and Borneo - Vogelkop (Tamrau terrane) - Star Mts. The taxa in the second are related to a third E Borneo track: Kinabalu - Mt. Kemul. There is a strong massing on Kinabalu as in Diplycosia IV and V. In addition to these montane plants, the Kinabalu region has endemic lowland species, such as Caesalpinia oppositifolia Hattink: open spaces in primary forest, up to $600 \mathrm{~m}$, Kinabalu and Sandakan (NE Sabah) (Hou, Larsen and Larsen 1996). A Philippines - New Guinea connection similar to that of Diplycosia 10-11 is seen in the fern Belvisia platyrhynchos (Kunze) Copel. (Polypod.) of Luzon, Mindoro, Mindanao, and Japen I. (Hovenkamp 1998), the last locality comprising part of the Arfak terrane.

Diplycosia II. (Fig. 39). The species shown here do not comprise a single group, but rather four basal groups in, respectively: Latimodjong Range; Kinabalu; the Gajo Lands; and CE Sulawesi - N Borneo. The last range illustrates Wallace's Line as a centre of endemism, rather than a boundary line (cf. Tan 1998).

Diplycosia III. (Fig. 40). These species largely surround Borneo to the north and are vicariant with groups in Diplycosia I, IV and V which mass in Borneo. New Guinea disintegrates into the following tracks: Philippines - Vogelkop; Wandammen Cyclops terrane; North Sumatra (Gajo Lands) - Sepik terrane (Hunstein Mts./Sepik Basin); Mt. Bonthain - old cratonic New Guinea (Kubor Mts). Two species $(34,41)$ show the important break between Tamrau and Netoni terranes (cf. Diplycosia I), and the two varieties of sp. 28 show the same break, with one in the Tamrau and Tohkiri Mts. (Tamrau terrane), the other in the Nettoti Mts. (Netoni terrane) and Arfak Mts. (Arfak terrane)

Diplycosia IV. (Fig. 41). This group is massed in northern Borneo and the Latimodjong/Paloppo/Makale region of C Sulawesi, and again Wallace's Line (77-78) appears as a centre of endemism in its own right, rather than simply as a boundary. New Guinea is held by two parallel arcs: Aceh-Vogelkop (cf. Diplycosia III, Gaultheria II etc.) and Mindanao-Doormantop. Like these arcs, spp. 69-78 (black in figure) also largely surround the massing of species in Sarawak. 


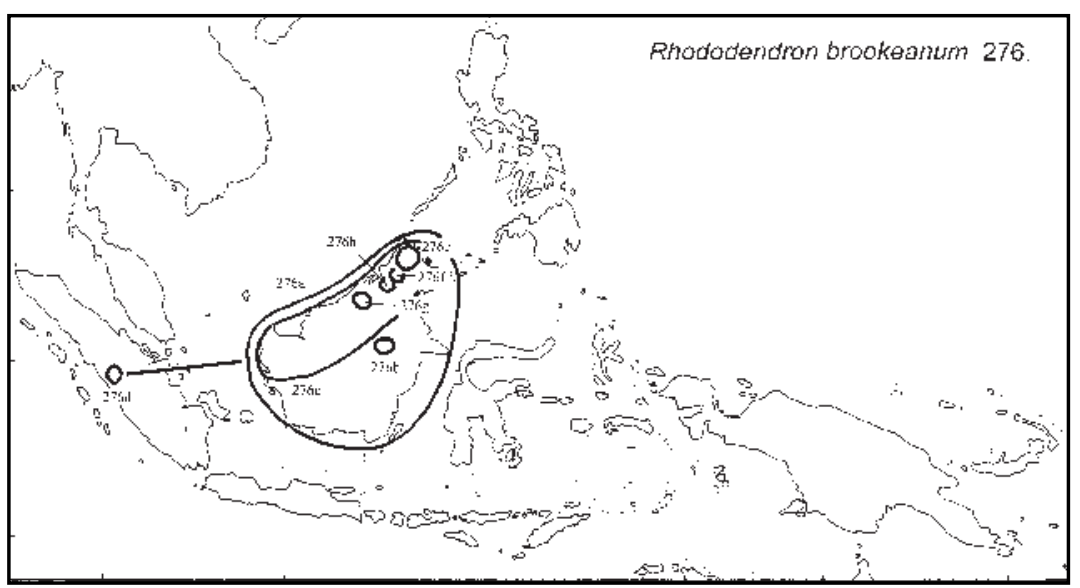

Fig. 33. Rhododendron brookeanum. 276c is R. b. var kinabaluense (Argent, Lamb and Philips) Argent; $276 \mathrm{f}$ is R.b. subsp. cockburnii (Argent, Lamb and Philips) Argent; $276 \mathrm{~g}$ is R. b. subsp. gracile (Lindl.) Argent; $276 \mathrm{~h}$ is R. $b$. var. moultonii (Ridl.) Argent.

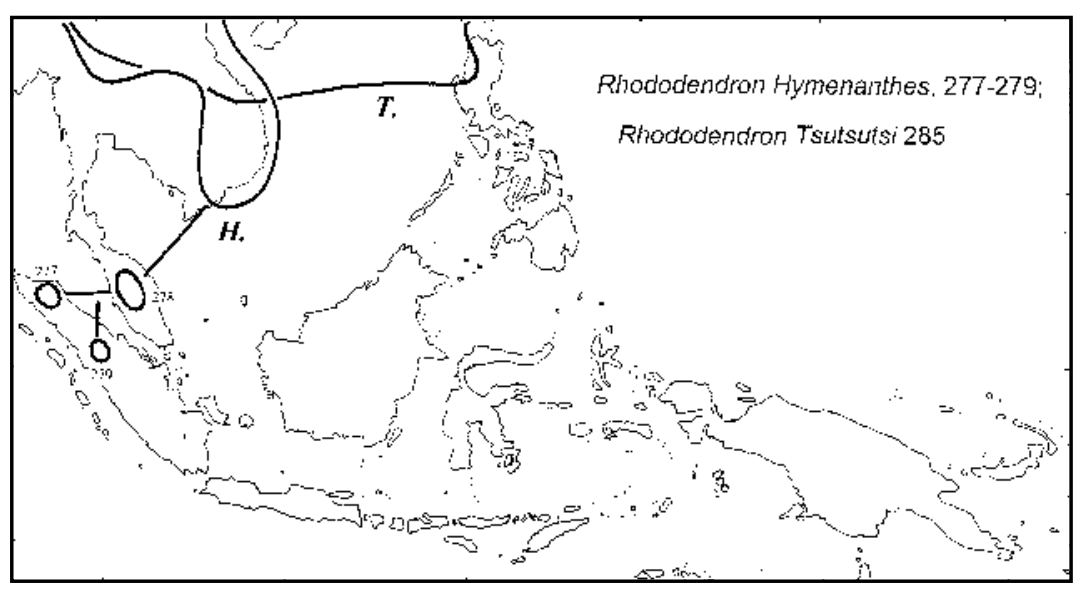

Fig. 34. Rhododendron subgen. Hymenanthes, and R. subgen. Tsutsutsi.

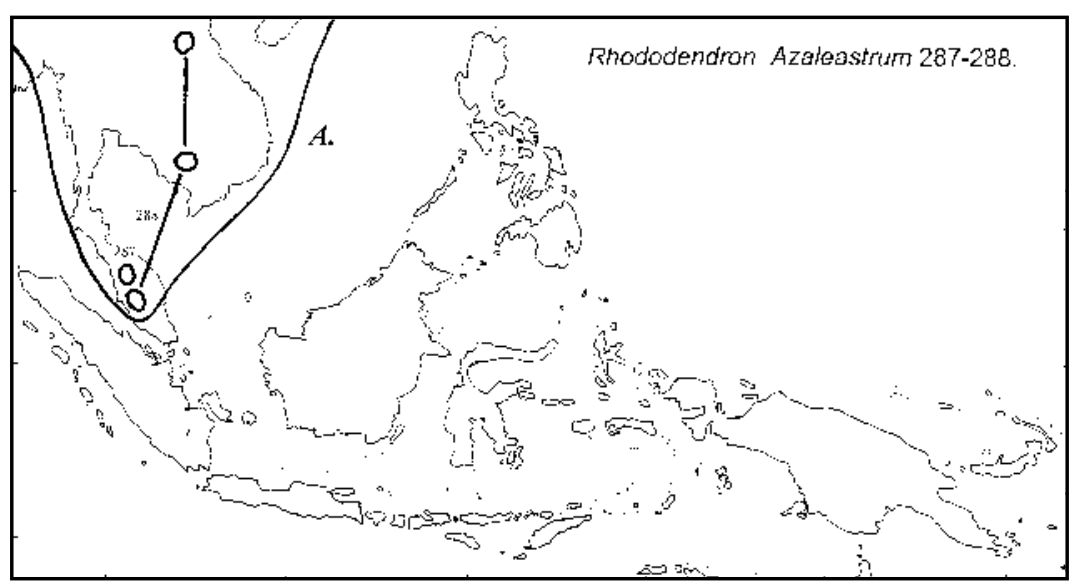

Fig. 35. Rhododendron subgen. Azaleastrum. 


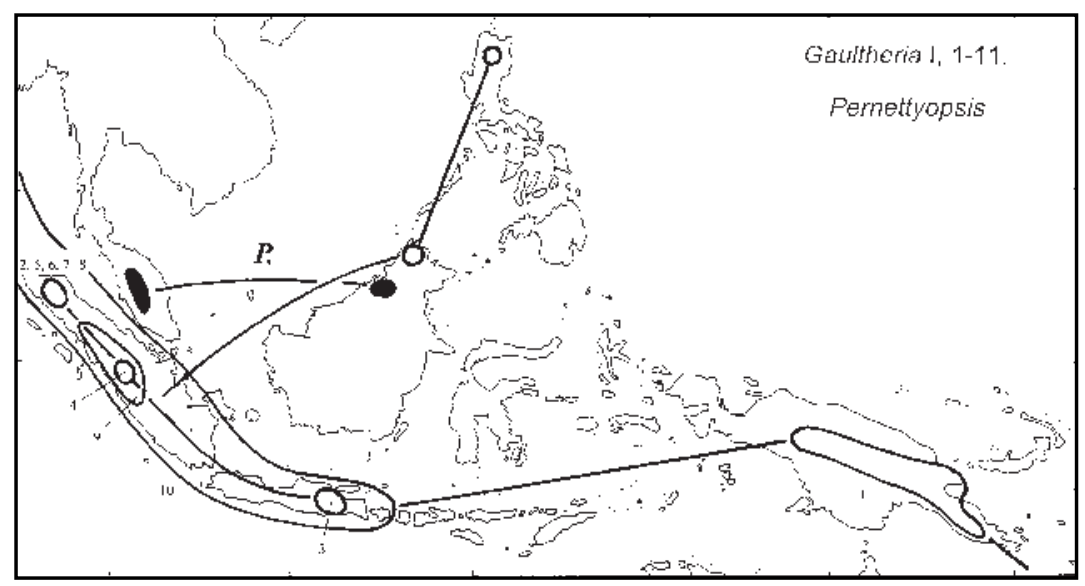

Fig. 36. Pernettyopsis and Gaultheria I.

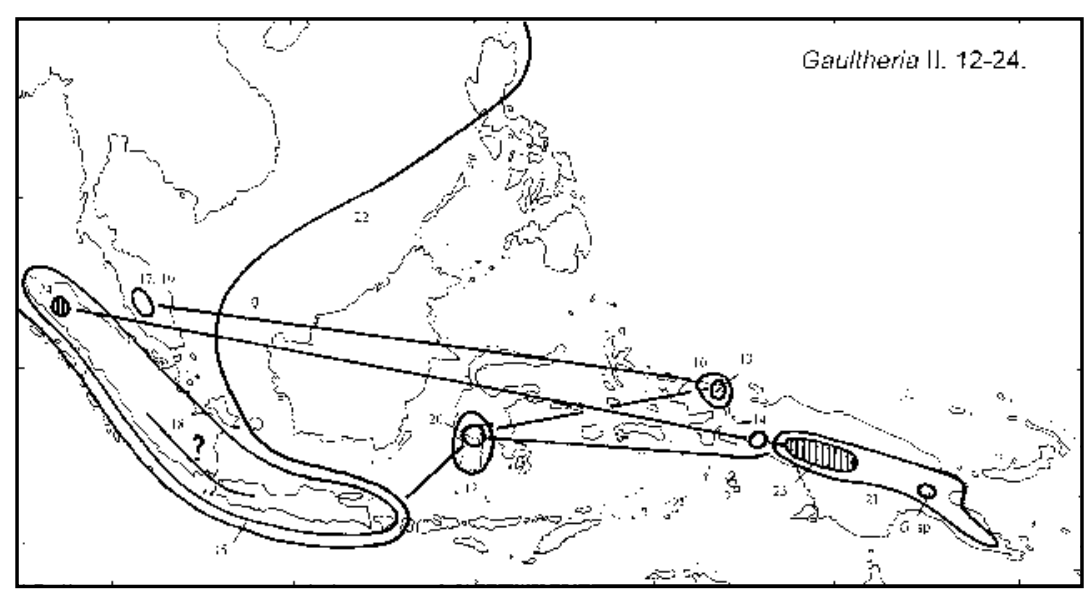

Fig. 37. Gaultheria II. The distribution of 18 is given as 'Java (Merapi) or Sumatra (Lower Tapanuli)'. Gaultheria sp from Crater Mountain (indicated on the map) 'could be new' (Takeuchi 1999b).

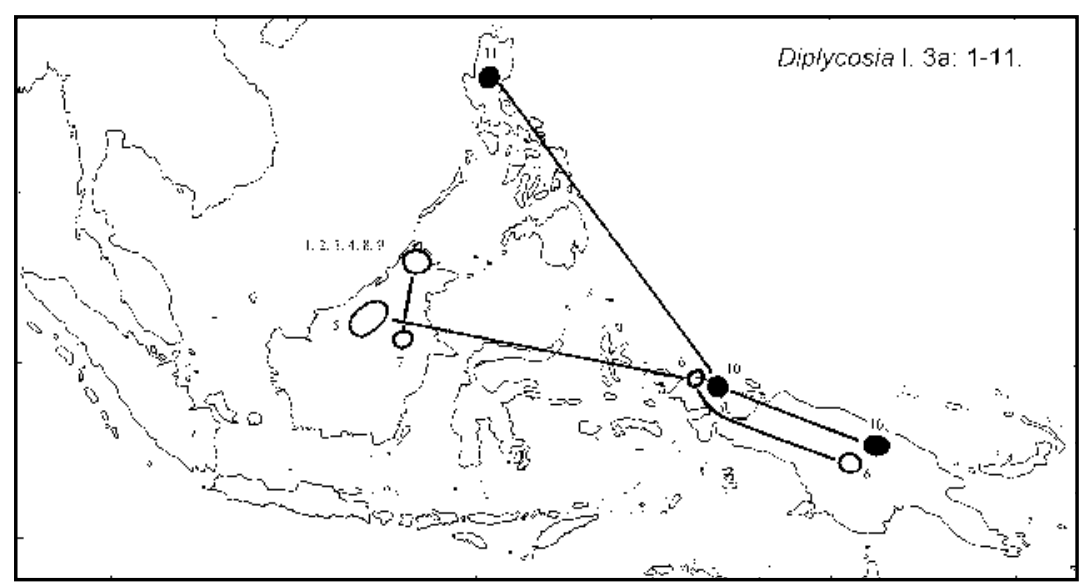

Fig. 38. Diplycosia I. 


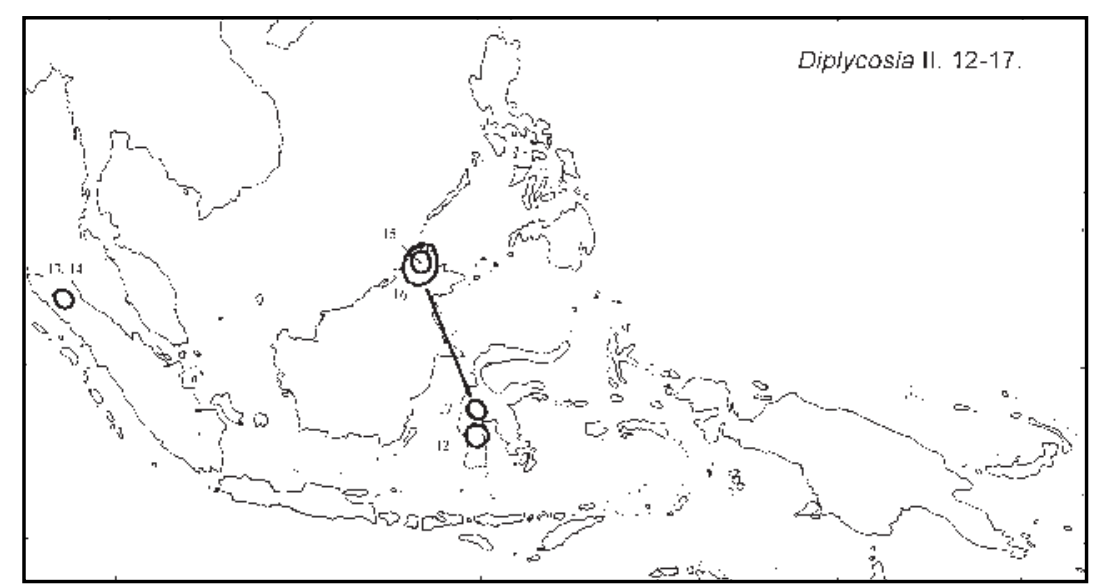

Fig. 39. Diplycosia II.

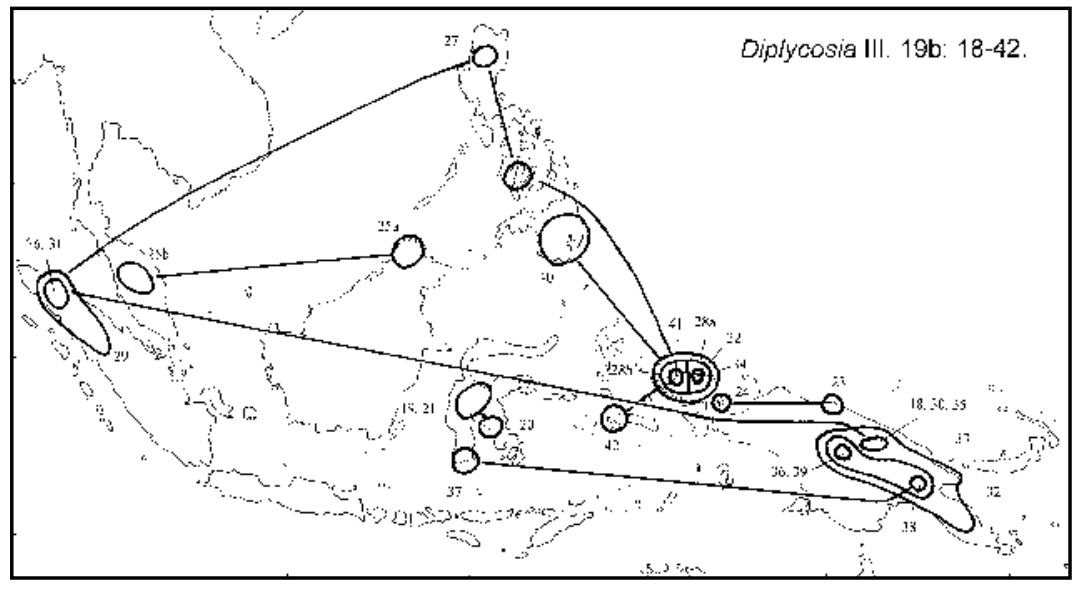

Fig. 40. Diplycosia III.

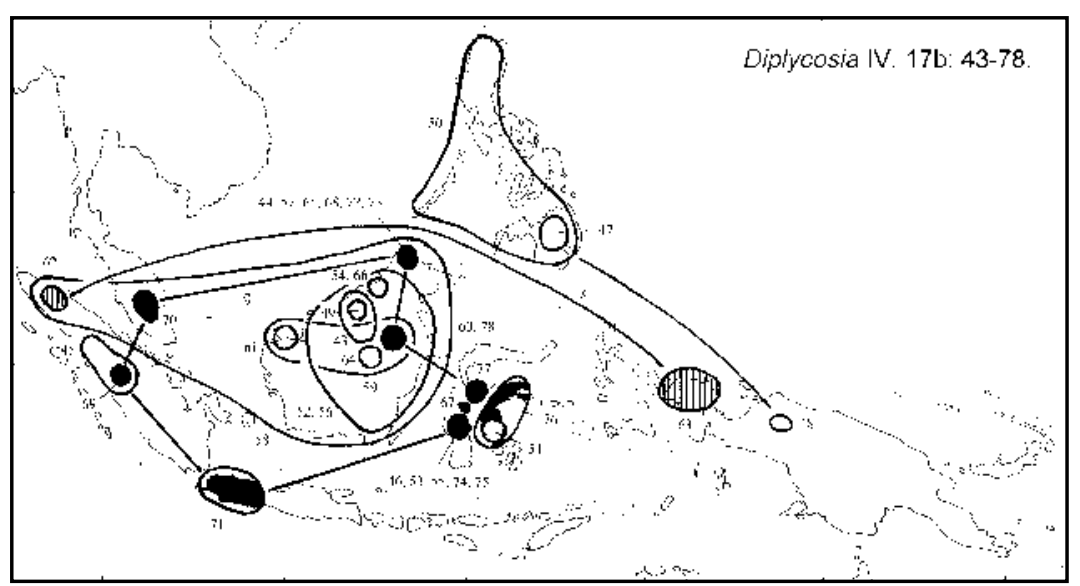

Fig. 41. Diplycosia IV. 
Diplycosia V. (Fig. 42). The group is divided into largely eastern (79-90) and western (91-96) groups, but sp. 80 in W Sumatra is allied with the eastern group. The map is very similar to that of Vaccinium sect. Bracteata IX, below. The large disjunction Kinabalu - PNG (Finisterre and Owen Stanley terranes) is also seen in Grammitis clemensiae (Copel.) Parris (Parris 1983). A similar pattern is seen in Phytocrene Wall. (Icacin.) which extends east past Borneo to Sulawesi, and is disjunct from there to PNG: Morobe (Boana) and Mt Victoria (Sleumer's 1971a map does not quite match the text), and cf. Lamiodendron (Fig. 130).

Costera J.J.Sm. (Fig. 43). The widespread species 9 ranges around the Riouw Pocket, as does the track: SW Sumatra - Karimata I. (cf. Diplycosia V). The Mt. Kemul area is crucial here, but Kinabalu, where Diplycosia has its main massing, has no endemics.

The presence of Costera (Vaccinioideae, Pacific Ocean) in the northern Moluccas is significant as Rhododendron (Rhododendroideae, Indian Ocean) is only in the southern Moluccas, indicating local vicariance of the two subfamilies.

\section{Vaccinium in Malesia}

Vaccinium has six sections in Malesia, of which three — Pachyanthum, Neojunghuhnia and Oarianthe - are in the east. Sect. Bracteata is similar, with about two thirds of its species in the Philippines, Moluccas and New Guinea. In contrast, sects. Rigiolepis and Galeopetalum are concentrated in the west. The Himalaya-China region is an important centre for Vaccinium with about 100 species but this is quite distinct from the Malesia centre, and only two sections (Bracteata and Galeopetalum) occur in both.

Vaccinium sect. Pachyanthum Sleum. (Fig. 44). Stevens (1974a) transferred this distinctive group to Dimorphanthera, but molecular studies indicate that it is closer to 'Agapetes' subgen. Paphia (Seem.) Stevens and here it is retained in Vaccinium. PNG has all six species (five between Doma Peaks and Mt Victoria); and apart from one on the border, Irian Jaya has none. This pattern is unlike any Rhododendron group, but recalls 'Agapetes' subgen. Paphia (below). This is probably a reflection of the Pacific base of Vaccinioideae absent in Rhododendron.

Vaccinium sect. Galeopetalum (J.J.Sm.) Sleum. (Fig. 45). This ranges all the way from SE Tibet through Indochina and Malesia to W Java, but it is not in Borneo. However, it is keyed with the next group, sect. Rigiolepis, which has 19 of its 25 species in Borneomainly in Sarawak and Kalimantan (there is only one at Kinabalu).

Vaccinium sect. Rigiolepis (Hook.f.) J.J.Sm. (Fig. 46). Sp. 22c is endemic to the Mentawei Islands where there are also high rates of endemism in other plants, birds and primates. Sp. 27 is terrestrial on limestone rocks, epiphytic on mangroves; and follows the common mangrove track: Riouw Pocket (e.g. Lingga Archipelago) - SW Borneo, but neither this widespread species nor its many Borneo relatives, occur around Kinabalu. The Kinabalu species is related not to other Borneo species but to one from Sulawesi.

This and the last group, both in W Malesia, are sister to the remaining Vaccinium groups (spp. 30-239), widespread in Malesia.

Vaccinium sect. Oarianthe Schltr. I. (Fig. 47). As in Diplycosia III, plants of the Tamrau terrane (39) are distinct from those of the Arfak and Netoni terranes (36). There is a disjunction (in 40) between the Schrader terrane/Upper Minj R. and the Owen Stanley terrane, and also one (in 30) between the Arfak and Bismarck Mts. (Takeuchi 1999a). 


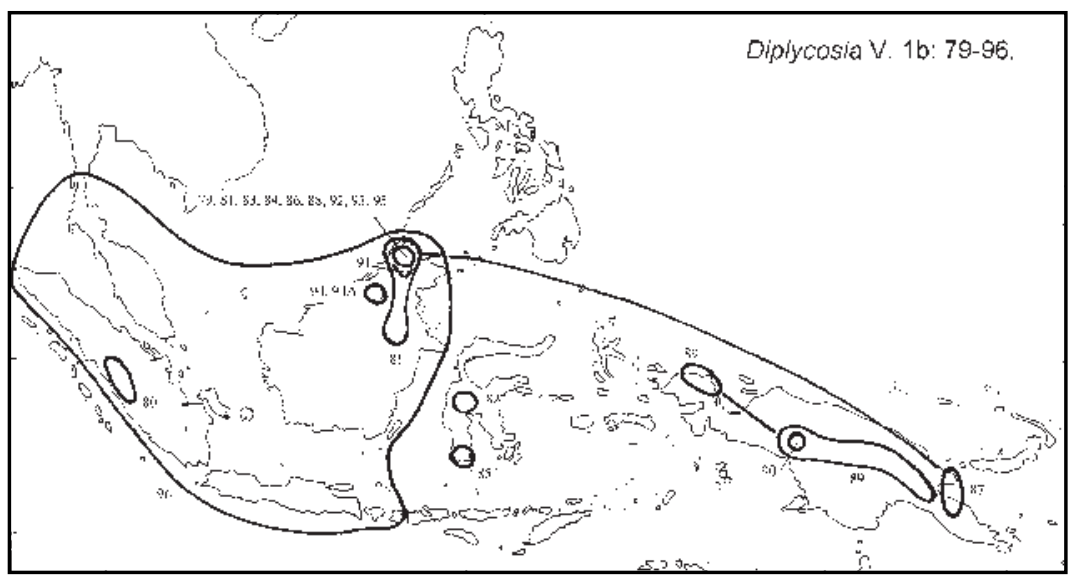

Fig. 42. Diplycosia V.

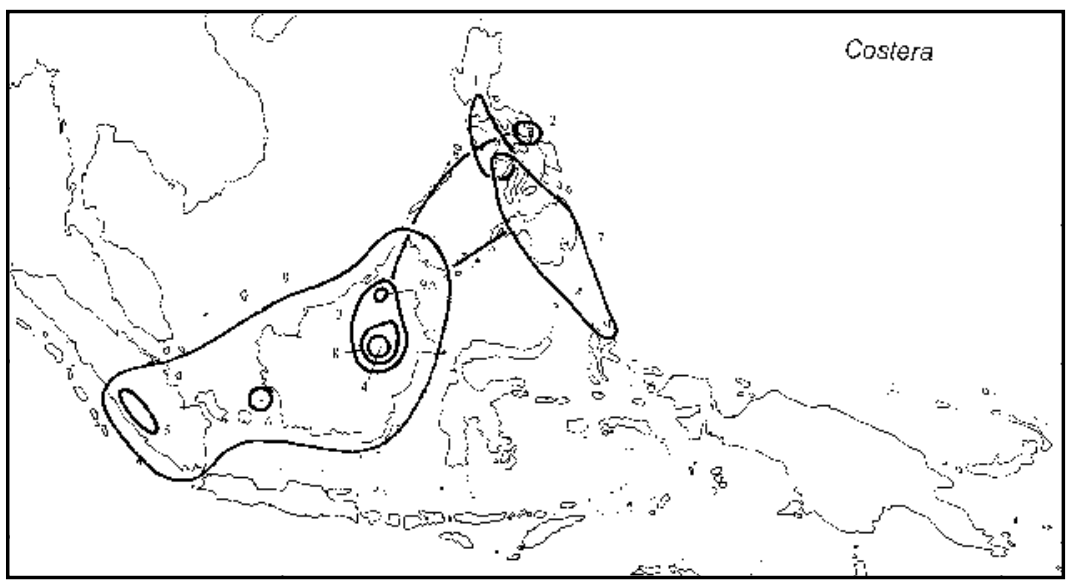

Fig. 43. Costera.

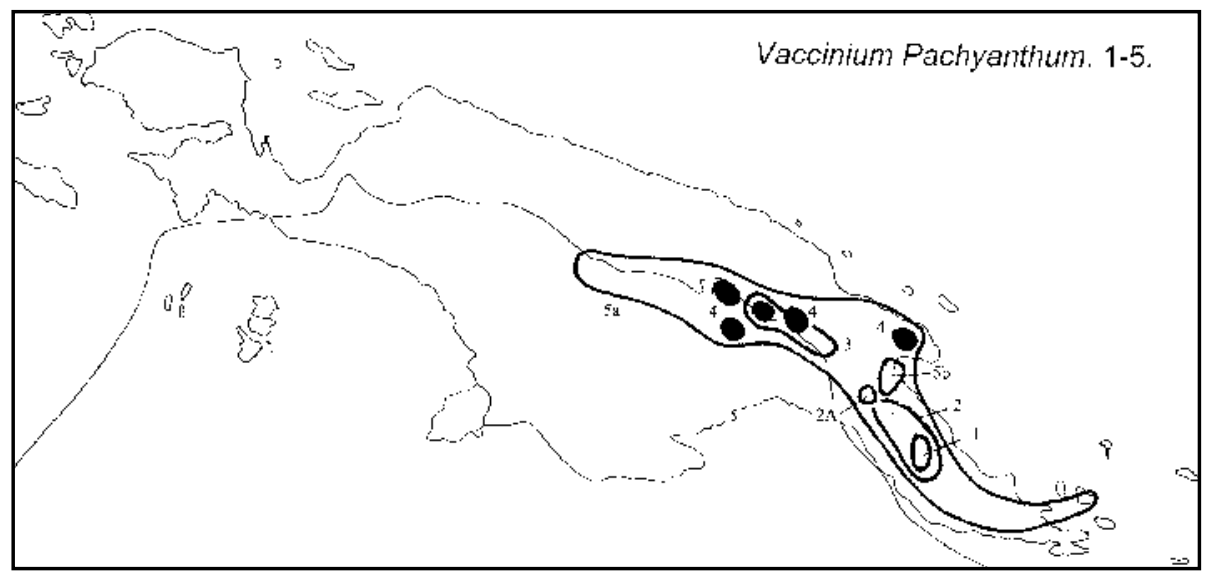

Fig. 44. Vaccinium sect. Pachyanthum. 


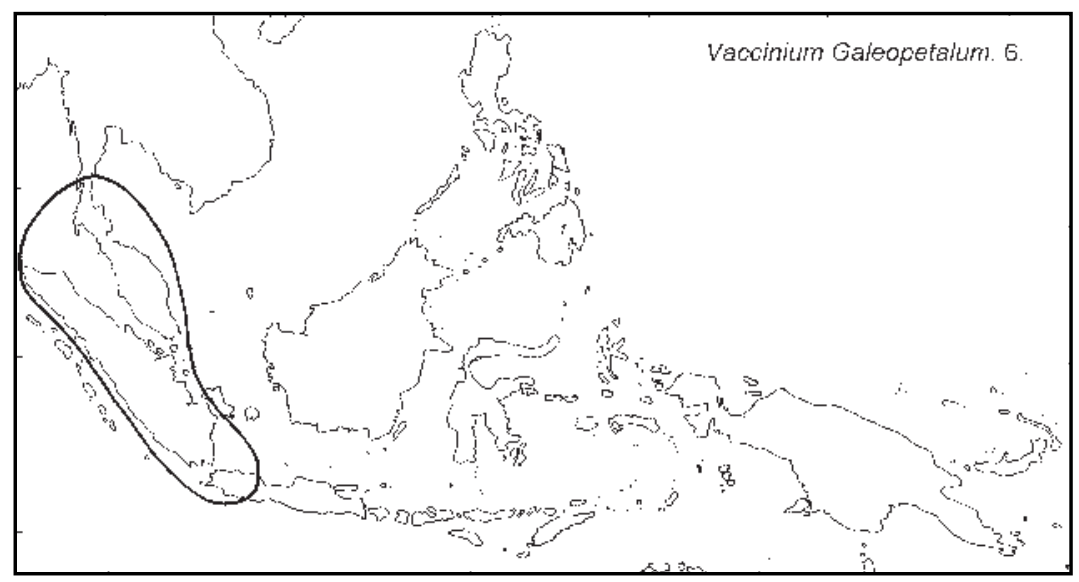

Fig. 45. Vaccinium sect. Galeopetalum.

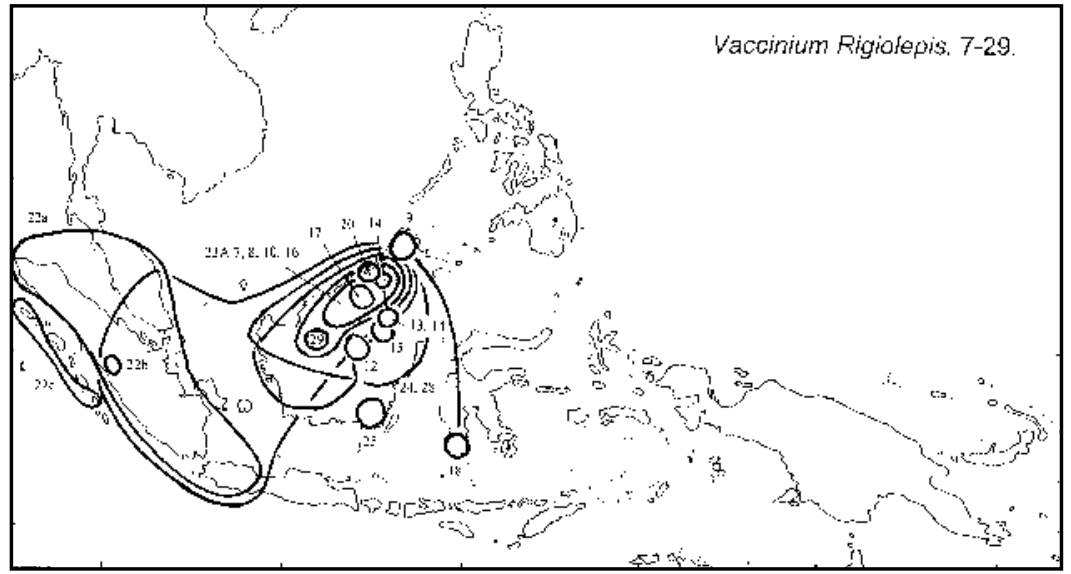

Fig. 46. Vaccinium sect. Rigiolepis Four species have not been located: 11. C Borneo (Amai Ambit), Sarawak (Ulu Mayeng, Sg. Kakus), 12. C Borneo (Batu Lesong, U. Kapuas). 23. Sarawak (Gat, U. Rejang R.), 26. Sarawak (Mt. Api).

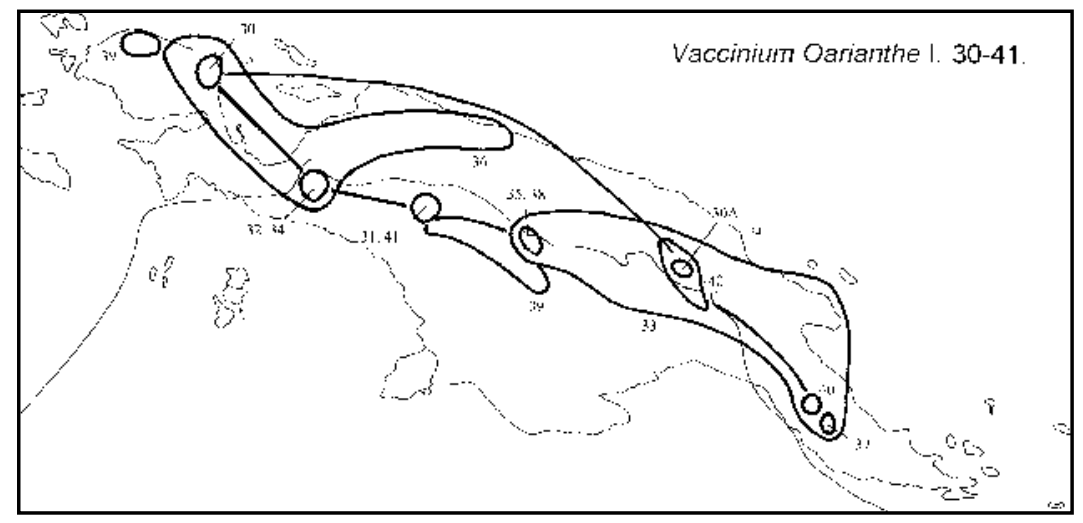

Fig. 47. Vaccinium sect. Oarianthe I. The Bismarck Mts. record of Vaccinium sp. aff. 30 is from Takeuchi (1999). 
Vaccinium sect. Oarianthe II. (Fig. 48). This comprises four parallel arcs: Vogelkop-Cyclops terrane etc.; Wandammen - upper Sepik (10 km south of Landslip terrane: known from the type only, lost); Ceram - W Nassau Mts - Doormantop (the last locality with the most dramatic disjunction, as usual) - Bougainville; Snow Mts Saruwaged Mts.

Vaccinium sect. Oarianthe III. (Fig. 49). The outer arc species at Philippines/Moluccas Vanuatu is sister to the rest in W New Guinea, five of which have concentric distributions on Doormantop - Oranje Mts. A similar striking disjunction occurs in Ginalloa arnottiana Korth., of Borneo, Sulawesi, the Philippines and Moluccas, and also the Solomons (Barlow 1997). The intervening area in New Guinea and New Britain is occupied by the related G. flagellaris Barlow. Species of Dacrydium (Fig. 80) and Podocarpus (Fig. 87) show the same Moluccas - Solomons disjunction.

Vaccinium sect. Oarianthe IV. (Fig. 50). Sp. 60 has the disjunct range: Arfak - Wondiwoi - Wissel Lakes, on the edge of the craton. This group and the last are poorly represented in PNG (unlike sect. Oarianthe V (next), sect. Pachyanthum, etc.).

Vaccinium sect. Oarianthe V. (Fig. 51). N Philippines - PNG, like Solenovireya II and Javanica VI (and cf. Oarianthe II: Philippines-Vogelkop). The Huon Peninsula species (72) is more closely related to the Irian Jaya species than to the other PNG species, as in Oarianthe II.

Vaccinium sect. Neojunghuhnia (Koord.) Sleum. (Fig. 52). One group (74-77) has three of its four species on widely disjunct accreted terranes (Arfak terrane, Sepik terrane (April R.), Owen Stanley terrane (Mafulu)), and one on the craton in the Oranje Mts at Mt Resi. The other group (78-86) is only on the craton.

Vaccinium sect. Bracteata Nakai. This group (Sleumer 1967: Fig. 95) is most diverse in New Guinea (74 species) and Philippines (28), with only 16 in Borneo. The PhilippinesNew Guinea axis (a standard connection in Pacific groups, see below) contrasts with the main centres of Malesian Rhododendron - New Guinea and Borneo. East of the New Guinea mainland $V$. sect. Bracteata is at New Caledonia (and Vanuatu), a connection also seen in plants like Hunga Prance (Chrysobalan.) (Prance 1989).

Vaccinium sect. Bracteata I. (Fig. 53). sp. 87 (to Burma and China) and 88 are on seashores, sandy coasts and padang around the Riouw Pocket (Bangka, Billiton, Lingga Islands etc.) and in Sulawesi. Spp. 89 and 90 reach higher altitudes in Sulawesi. Borneo is surrounded and not occupied, although the group is on nearby Karimata Island.

Vaccinium sect. Bracteata II. (Fig. 54). Peninsular Malaysia - Mindanao - PNG (cf. Buxifolia III, Solenovireya II). Not in Borneo.

Vaccinium sect. Bracteata III. (Fig. 55). There are massings in Aceh, Luzon and Irian Jaya, and Borneo is surrounded, as in Bracteata $\mathrm{I}$.

Vaccinium sect. Bracteata IV. (Fig. 56). This ranges in Central Sulawesi and New Guinea, with the usual disjunction: Irian Jaya craton (Oranje Mts.) - PNG accreted terrane (Mt Victoria) (in 120). Sp. 125 (type only, lost) is at the West Range (Landslip and Dimaie terranes) (cf. 128, next). 


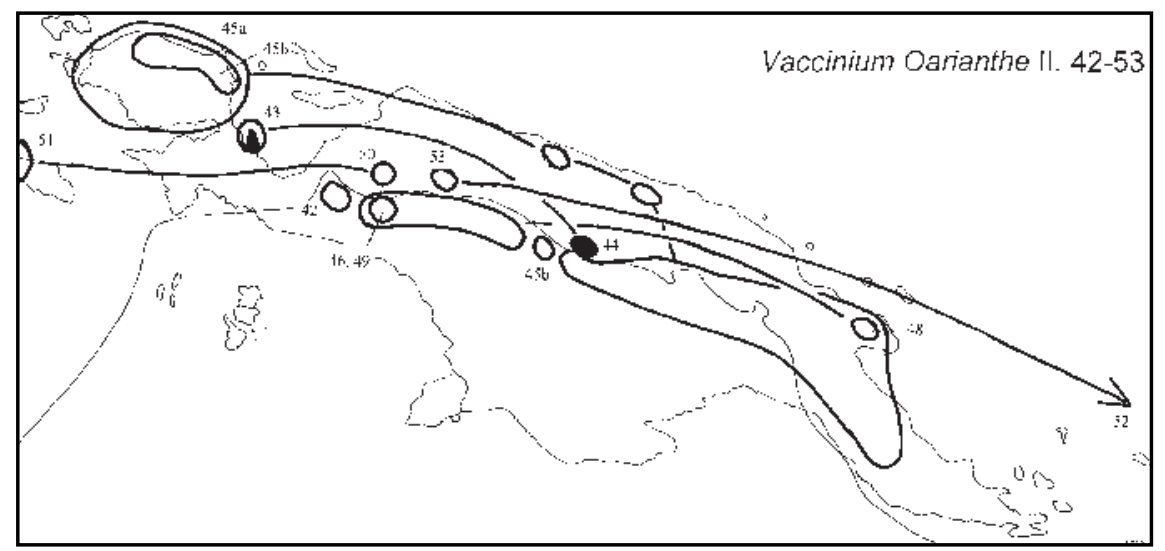

Fig. 48. Vaccinium sect. Oarianthe II.

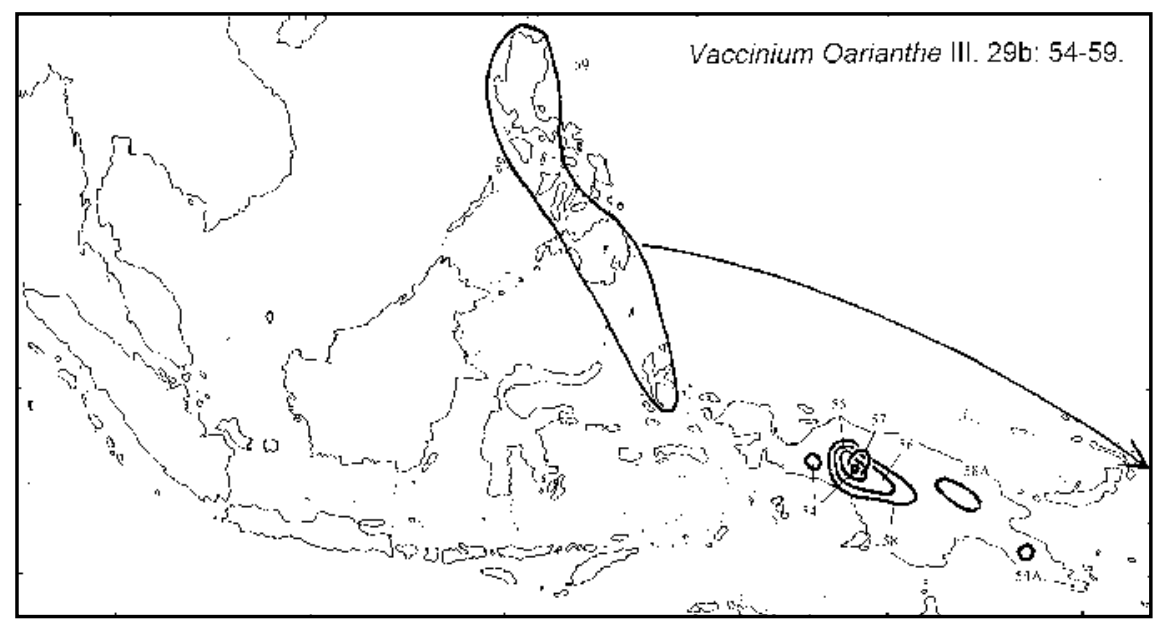

Fig. 49. Vaccinium sect. Oarianthe III.

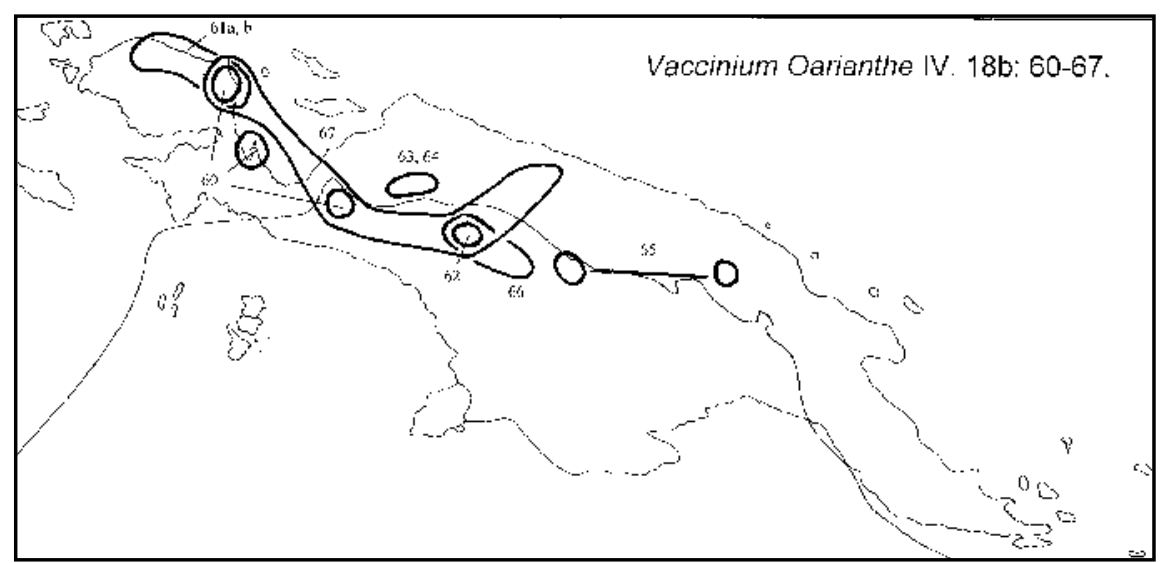

Fig. 50. Vaccinium sect. Oarianthe IV. 


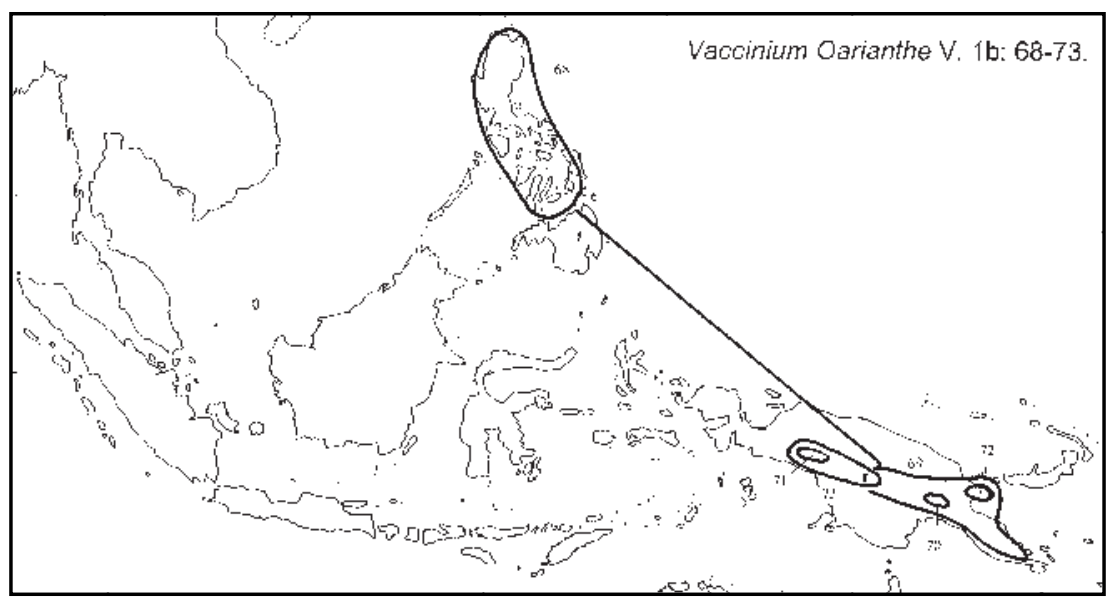

Fig. 51. Vaccinium sect. Oarianthe V.

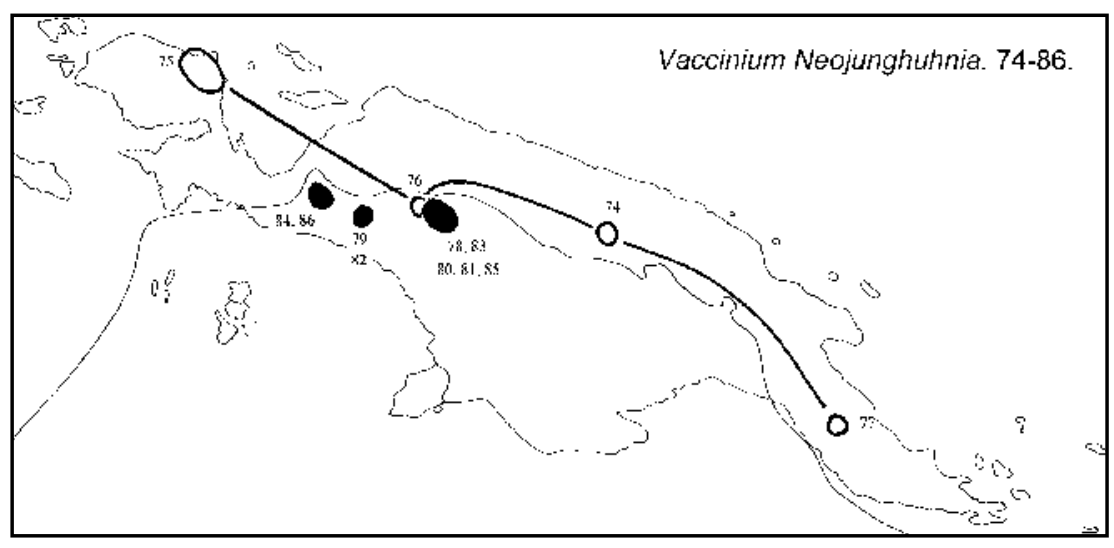

Fig. 52. Vaccinium sect. Neojunghuhnia.

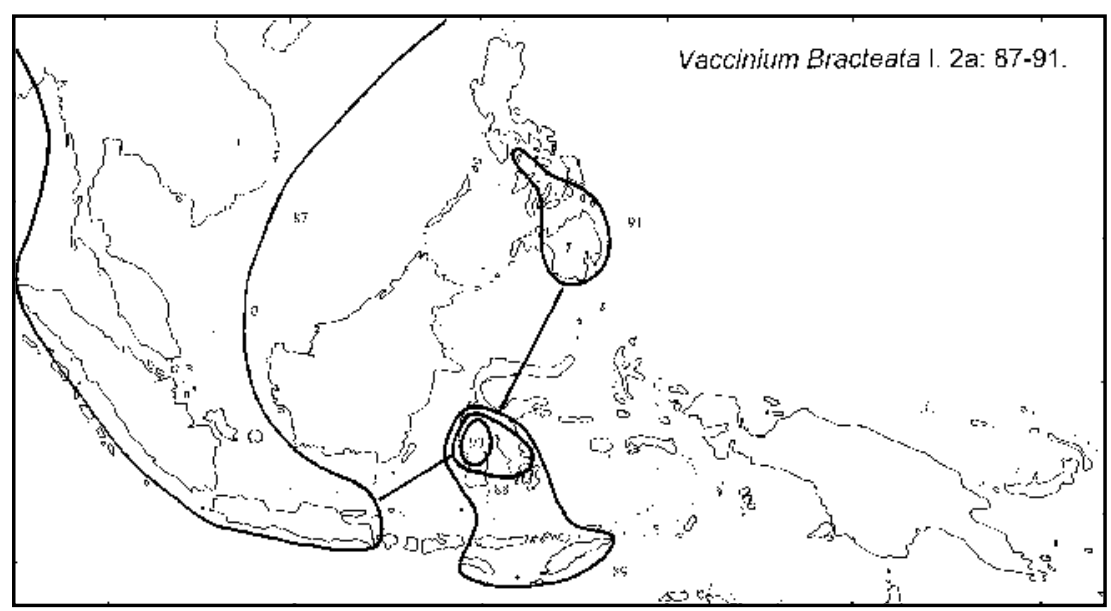

Fig. 53. Vaccinium sect. Bracteata I. 


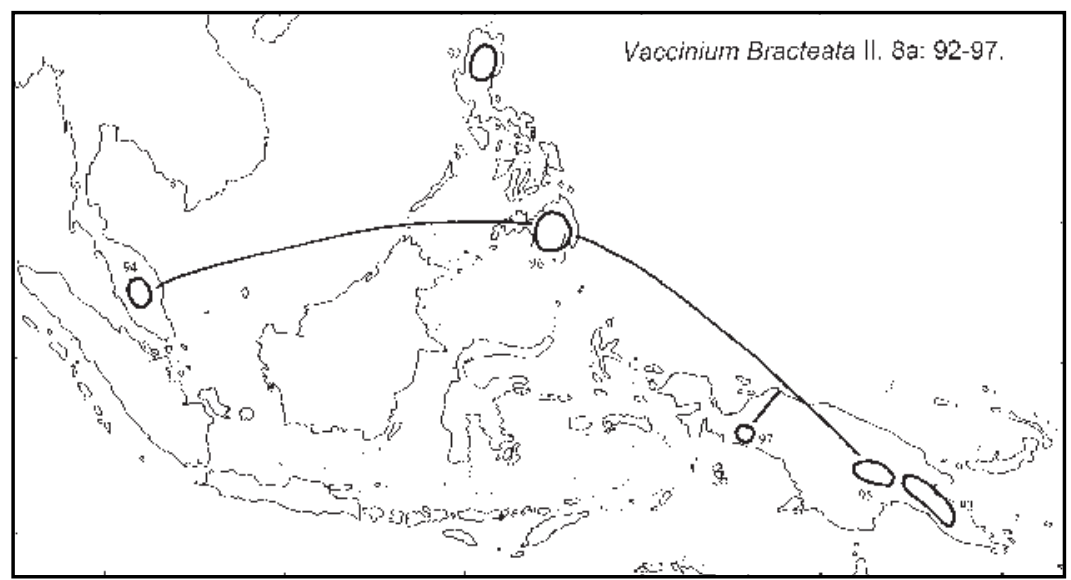

Fig. 54. Vaccinium sect. Bracteata II.

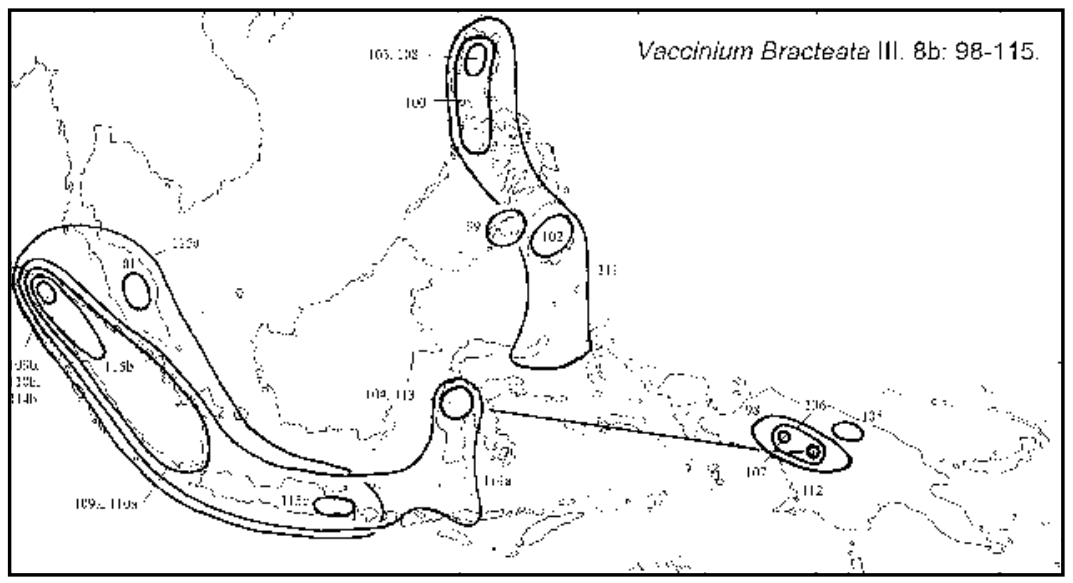

Fig. 55. Vaccinium sect. Bracteata III.

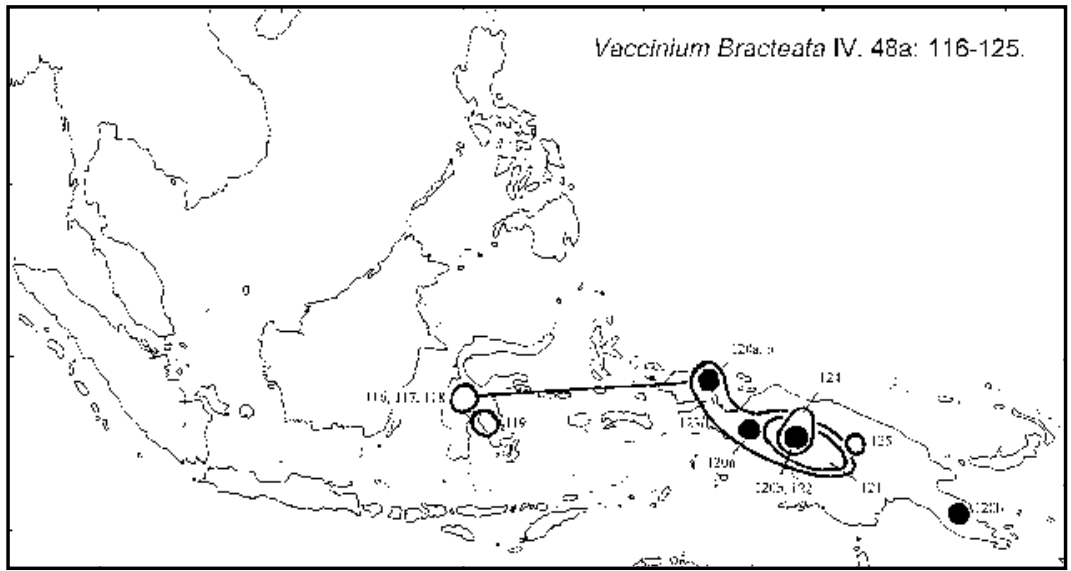

Fig. 56. Vaccinium sect. Bracteata IV. 
Vaccinium sect. Bracteata V. (Fig. 57). There are three parallel arcs: Rouffaer R. Torricelli Mts - Hunstein Mts (Sepik terrane) (126); Doormantop - near Bernhard Camp (127, both localities on Rouffaer terrane) and Lake Habbema (129) - West Range (128, type only, lost).

Vaccinium sect. Bracteata VI. (Fig. 58). The two species are at Kinabalu, and Batu Tiban - Mt Dulit. They are distinctive through their cordate leaves and appear in the key as sister to the rest of the genus (the next 107 species). Like Bracteata VIII and IX this is a Borneo group, vicariant with the next.

Vaccinium sect. Bracteata VII. (Fig. 59). Borneo/Sulawesi are surrounded. PNG has eight species (plus varieties), Irian Jaya only two and the group is not in the Snow Mts. The track: Rouffaer R. (143) - Aitape (144) can be compared with the distribution of sp. 126 in Bracteata V.

Vaccinium sect. Bracteata VIII. (Fig. 60). N Borneo - southern Philippines. This is an important pattern in which SW Borneo (Riouw Pocket) and SE Borneo (Meratus suture) are not involved.

Vaccinium sect. Bracteata IX. (Fig. 61). 158a (dunes and rocks by sea-shore) has the usual mangrove track: CW Sumatra and Borneo. This can be compared with the range of Vaccinium 27 (mangrove), Diplycosia 80, 81, Costera, and Rhododendron 226-227, 276 (mangrove). The disjunction: Borneo - Owen Stanley terrane (157, NW Owen Stanley Range, up to $2300 \mathrm{~m}$ altitude), again implies uplift of mangrove in East Malesia. The eastern species 153 (SE Owen Stanley Range, specimens from Mt. Obree differ from the others) is sister to the rest of the group, a Pacific-oriented pattern not seen in Rhododendron but present in both epacrid groups (below).

Vaccinium sect. Bracteata X. (Fig. 62). There are four separate groups shown here: the pair 160-161 centred on N Luzon is sister to the rest of sect. Bracteata, another Pacific pattern not seen in Rhododendron. Species 162 (West Ra., Hunstein - Schrader Mts.); 163-168, and 169-170 are each in turn sister to the rest of the genus. The disjunction between Doormantop (163) and the Papuan Peninsula (164), enclosing 162 in central PNG, is seen elsewhere in groups like Potentilla adenophylla Merr. \& Perry (Rosa.) of Doormantop and the Papuan Peninsula (Central and Milne Bay Provinces), which encloses the related P. brassii Merr. \& Perry of the New Guinea main range (Kalkman 1993). The Aceh-Palawan connection is also seen in Rhododendron 177, 178, 179. The Borneo species is in swamp forest on sandy soil at sea-level, while its relatives in New Guinea are montane in the Vogelkop, Doormantop and the Owen Stanley Mts.

Vaccinium sect. Bracteata XI. (Fig. 63). This comprises two parallel arcs: Luzon Mindanao - Talaud Islands - Vogelkop (Netoni terrane); and N Luzon - Negros Milne Bay (Dayman terrane). This shows the composite structure of both the Philippines and New Guinea.

Vaccinium sect. Bracteata XII. (Fig. 64). In Sumatra, in forest near the seashore and on limestone rocks (sp. 185); but in New Guinea in the mountains (with the highest record in PNG, at $3745 \mathrm{~m}$ ). The New Guinea distribution is in four parallel arcs: Luzon Goodenough I., Vogelkop - Mt. Ambua/Mt. Otto - Mt. Dickson; Sumatra - Hunstein Mts - Mt. Tafa; and, on the craton, Wissel Lakes - Mt. Goliath.

Vaccinium sect. Bracteata XIII. (Fig. 65). Borneo (including endemism on Mt. Kutei) Arfak Mts. 


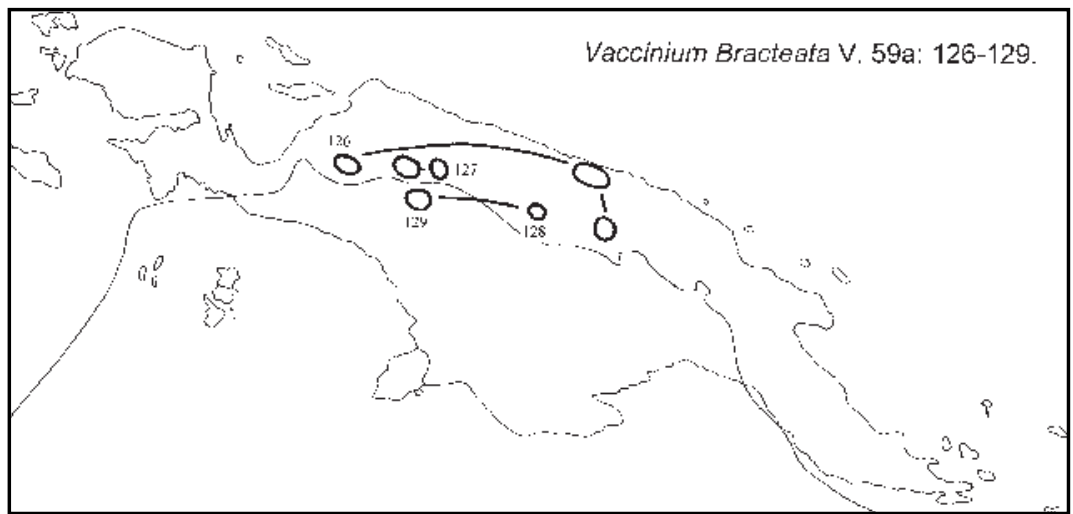

Fig. 57. Vaccinium sect. Bracteata V.

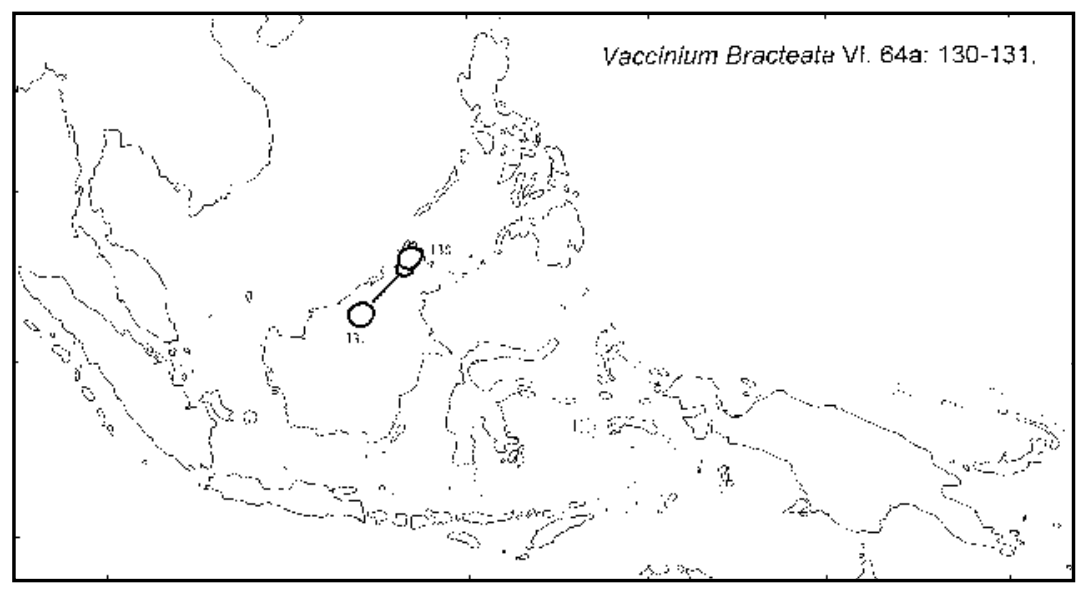

Fig. 58. Vaccinium sect. Bracteata VI.

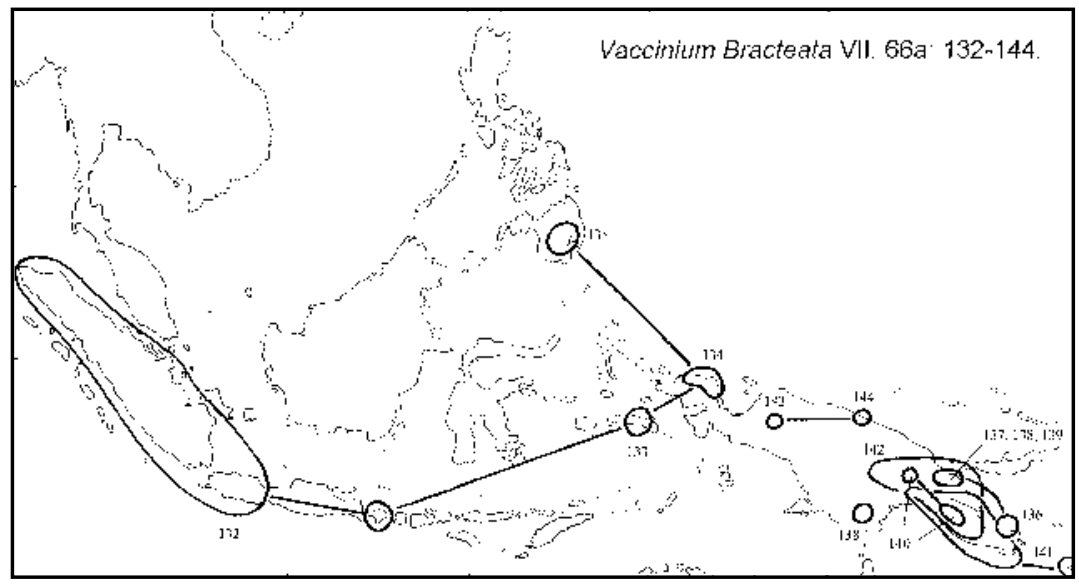

Fig. 59. Vaccinium sect. Bracteata VII. 


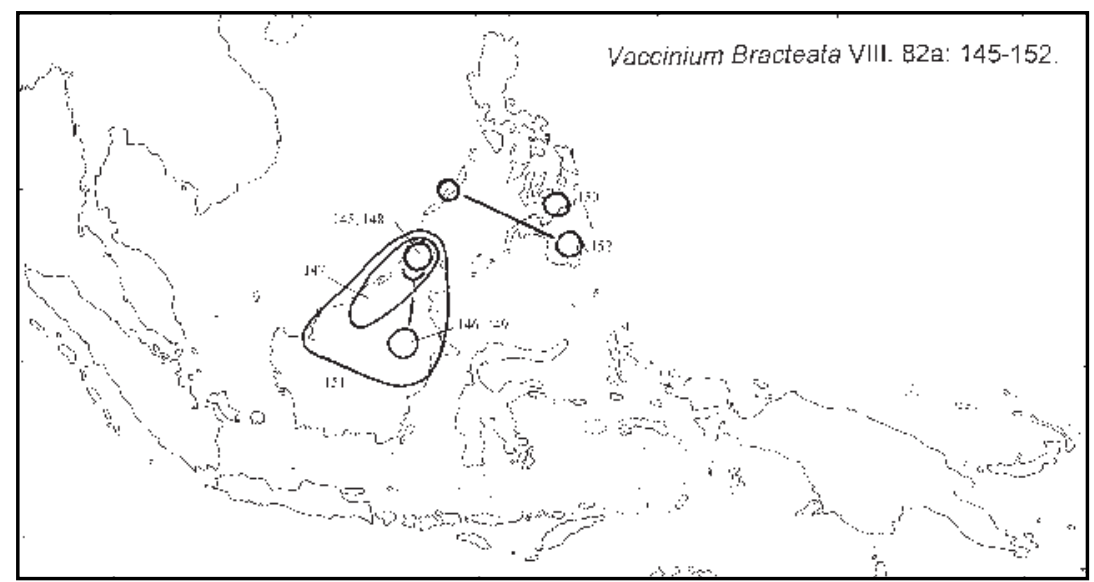

Fig. 60. Vaccinium sect. Bracteata VIII. The following localities for 149 were not located: Amai Ambit (C Borneo), Ulu Majong (Sarawak).

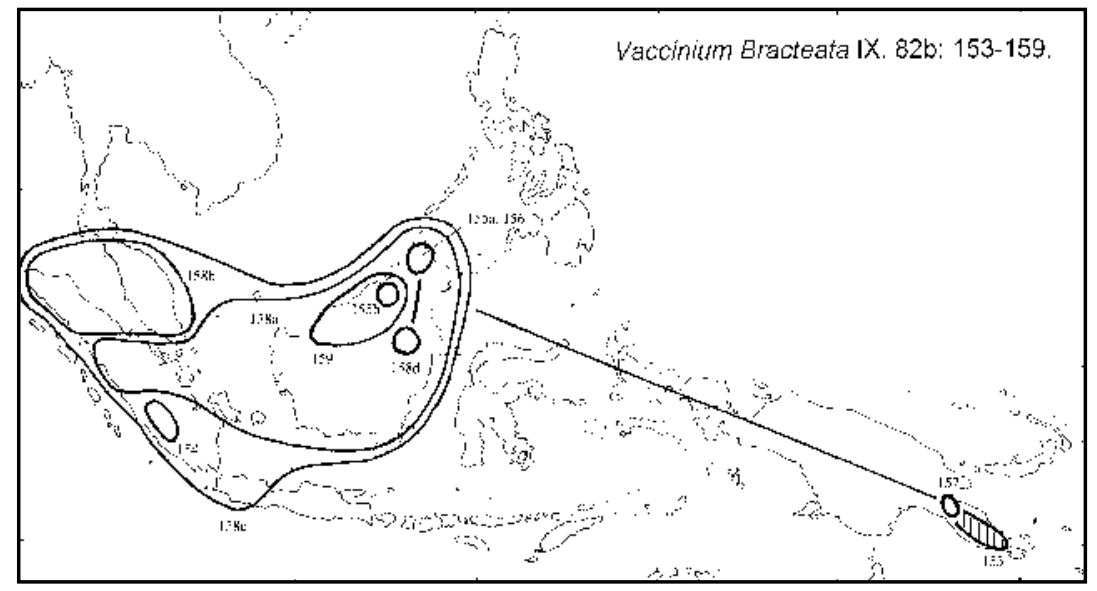

Fig. 61. Vaccinium sect. Bracteata IX. 155b is V. coriaceum var. hirsuticalyx Argent.

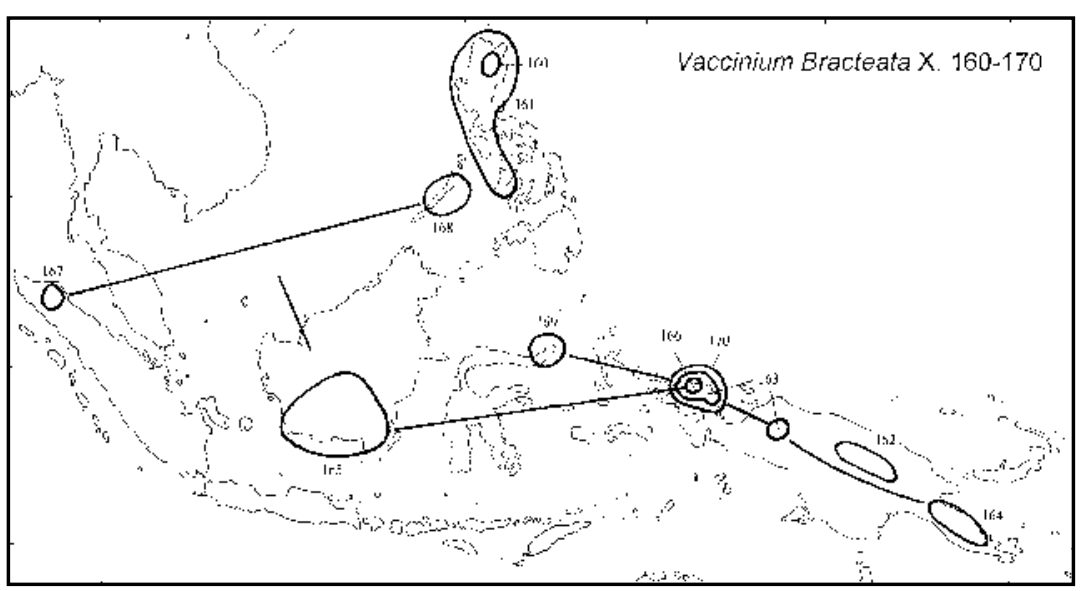

Fig. 62. Vaccinium sect. Bracteata X. 


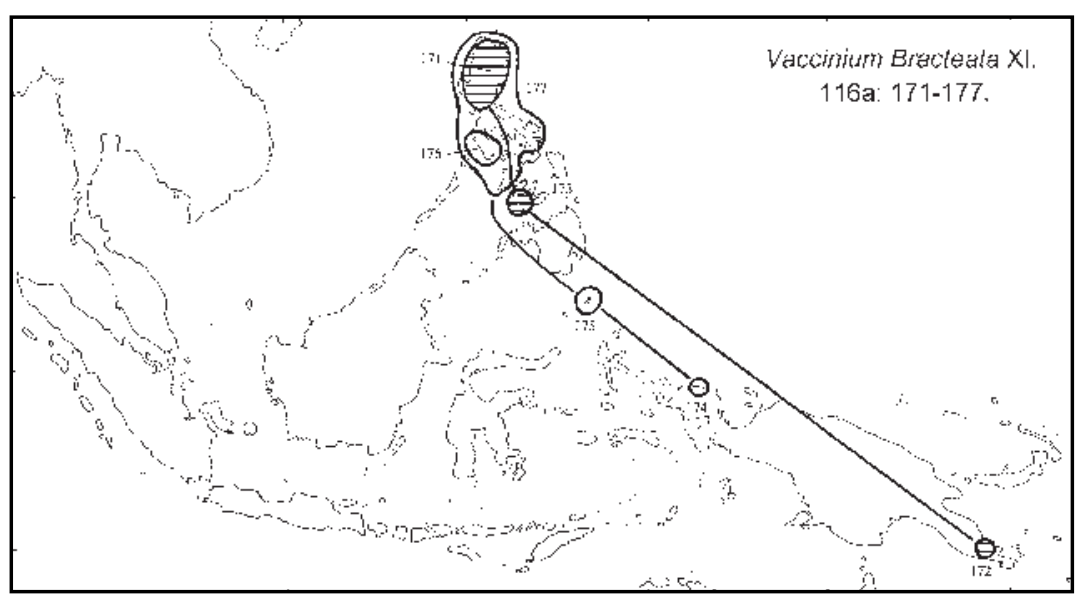

Fig. 63. Vaccinium sect. Bracteata XI.

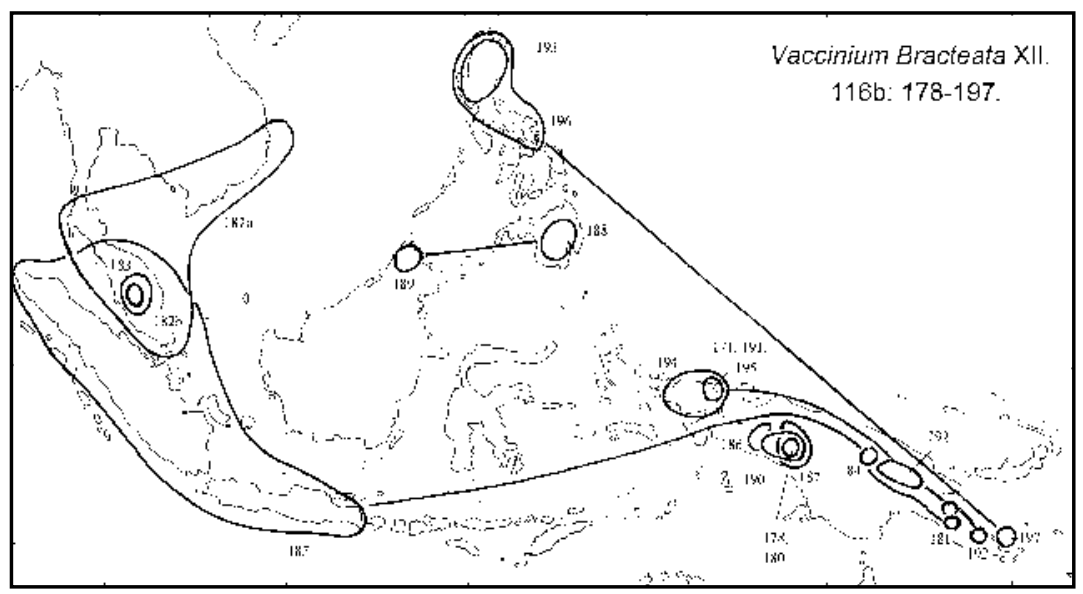

Fig. 64. Vaccinium sect. Bracteata XII.

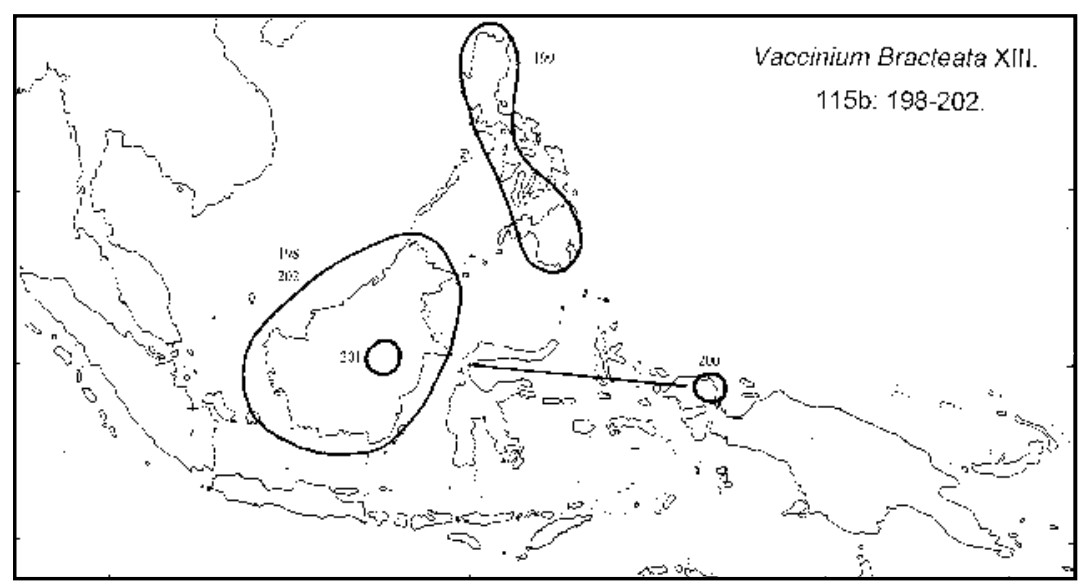

Fig. 65. Vaccinium sect. Bracteata XIII. 
Vaccinium sect. Bracteata XIV. (Fig. 66). There are endemics on the craton (e.g. the trio 203-205) and also on some of the accreted terranes, but no representation on Arfak or Finisterre terranes.

Vaccinium sect. Bracteata XV. (Fig. 67). Two parallel tracks, running Aceh Philippines - New Guinea - Sulawesi/W Malesia, largely surround Borneo, which has no endemic species. Species 219 (N Sumatra) and 220 (New Guinea) are keyed together, as are 222 (Doma Peaks, Mt. Hagen, and Mt. Giluwe, all Quaternary volcanoes on the craton), and 223 (Latimodjong Ra).

Agapetes subgen. Paphia (Seem.) Stevens (Fig. 68). Thirteen out of the 14 species occur between Mt. Amungwiwa/Mt. Shungol and Mt. Victoria (Stevens 1972, 1981), a 250 $\mathrm{km}$-long sector of the Owen Stanley terrane.

Dimorphanthera I. (Fig. 69). Philippines-PNG. The Vogelkop-Owen Stanley disjunction is similar to the Vogelkop-Huon disjunction seen in birds-of-paradise (Heads 2001b, 2002a). Species 1 and 2 comprise sect. Pteridosiphon Wernh., confined to Mt Carstensz. The other species on this map (3-15) comprise sect. Dimorphanthera. The remaining species of the genus make up sect. Trochilanthe Schltr.

Dimorphanthera II. (Fig. 70). This is on the craton in the west, with only two species out of eight. In PNG there are six species, on both the craton and the accreted terranes.

Dimorphanthera III. (Fig. 71). Three tracks converge near Mount Wilhelm: Torricelli Mts - Wabag - Okapa $(25,26)$; Vogelkop - Mt Piora (28-32); and a craton track (24; this species is sister of the first two groups). The middle track crosses a litle way onto the craton at Lake Kopiago (29), but here the species differs through its glabrous corolla.

Dimorphanthera IV. (Fig. 72). This comprises one widespread species, three endemics on the craton, and two on the accreted terranes forming a disjunction between Nassau Mts and the Owen Stanley, Port Moresby and Kutu terranes in PNG.

Dimorphanthera V. (Fig. 73). This is keyed out next to the last and has many endemics on the accreted terranes. 49: D. collinsii var. collinsii is on Mts Michael, Otto, Kerigomna and possibly Wilhelm (all off the craton). Dimorphanthera collinsii var. montis-wilhelmi is on Mts. Otto, Kerigomna, and Wilhelm, and also on the craton at the Minj-Nona Divide in the Kubor Mts. However, at this last locality it has a slightly different form, with less prominent basal glands on the lamina (Stevens 1974a). This recalls sp. 29, last map, and Rhododendron 191 (Buxifolia IV) which also show slight but possibly significant differences between the populations on the craton and those on accreted terranes.

Dimorphanthera VI. (Fig. 74). There are disjunctions between Irian Jaya species on the craton, and PNG species on accreted terranes. This resembles the disjunction in Macgregoria etc., but occurs here in three vicariant affinities. Species $65 \mathrm{~A}$ is in the Hydrographer's Range (= Sibium Mts) (Bowutu ophiolite terrane). 


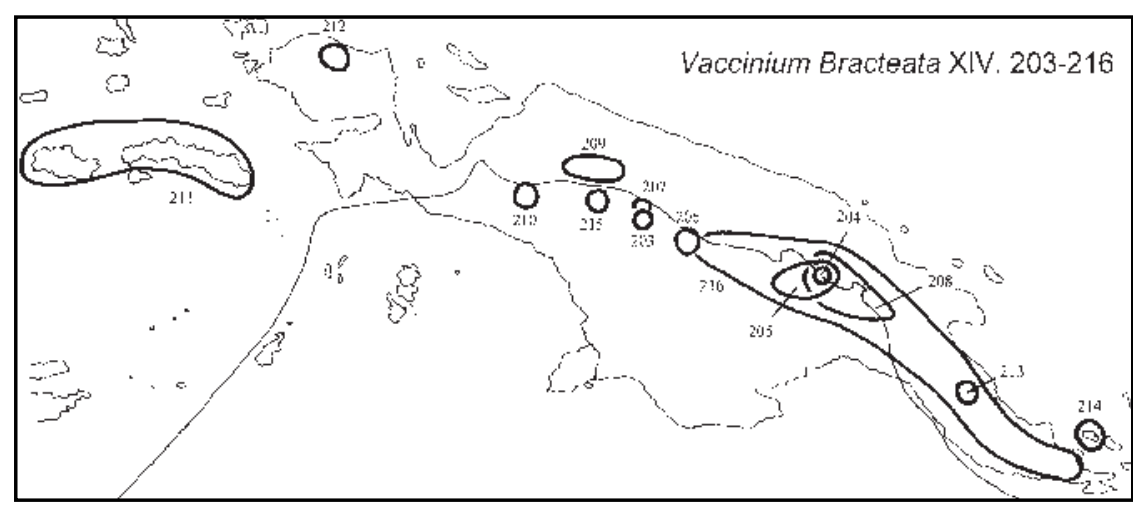

Fig. 66. Vaccinium sect. Bracteata XIV.

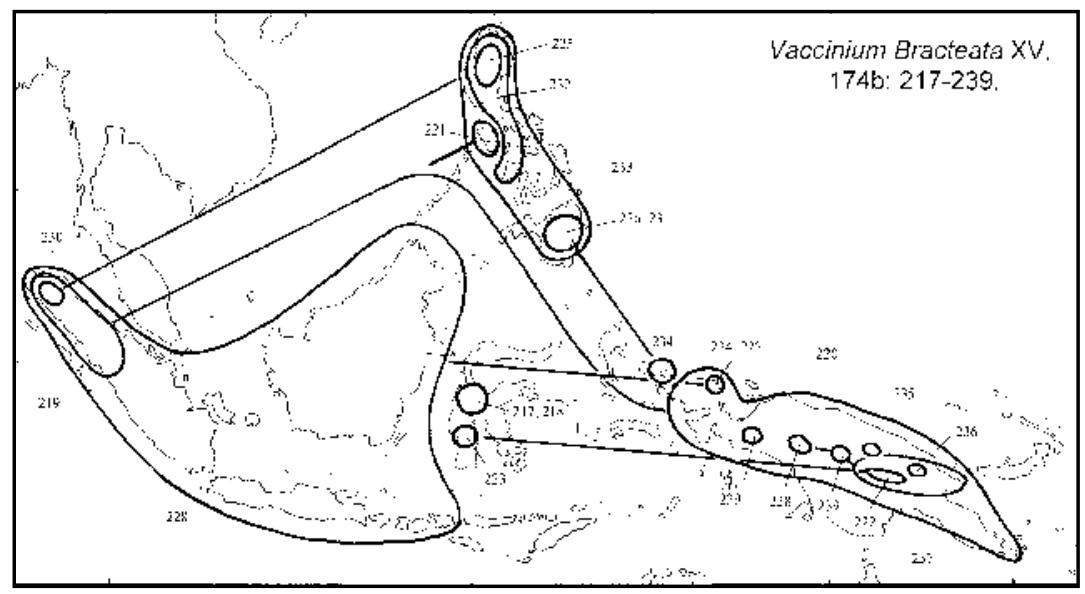

Fig. 67. Vaccinium sect. Bracteata XV.

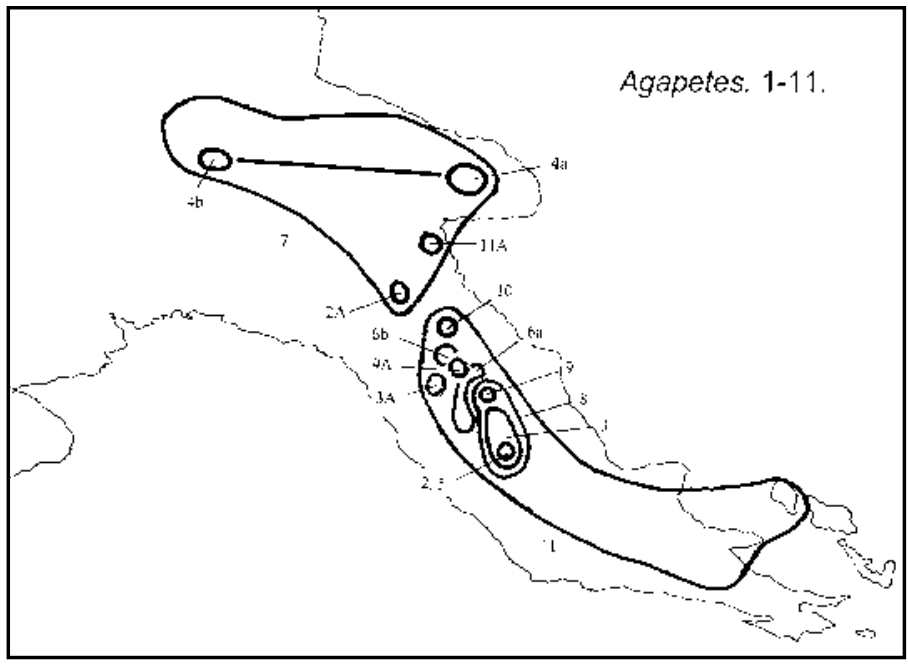

Fig. 68. Agapetes. 6b is A. brassii var. serratifolia Stevens. 


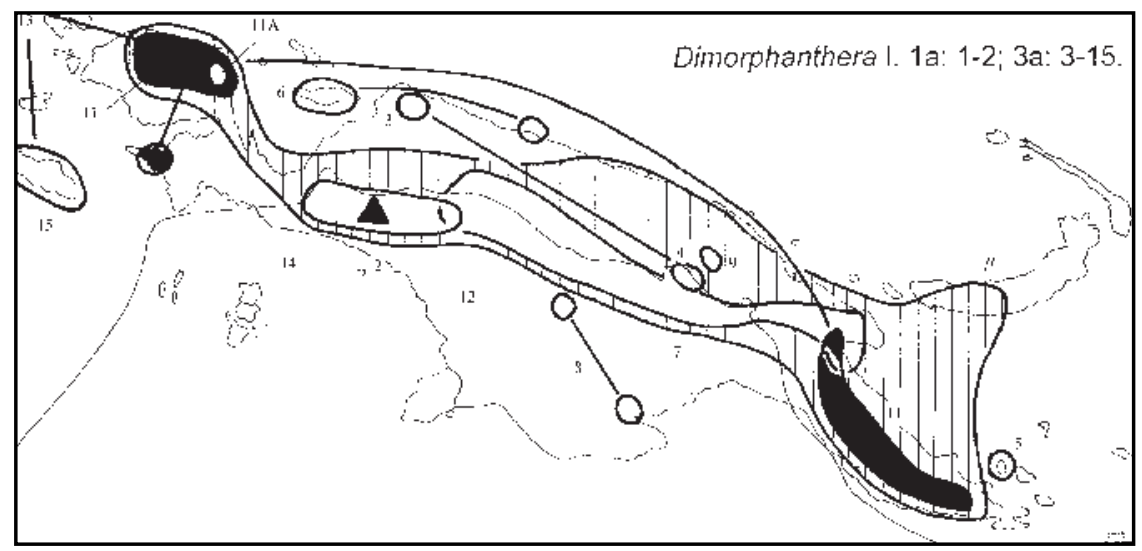

Fig. 69. Dimorphanthera I. 3 and 4 are included in 7 by Stevens (1974a) but are shown here as the possible cline is of geographic interest. 11A is the reinstated D. arfakensis J.J. Sm. 13 is included in 10 as a variety. 14 is a variety of 11 .

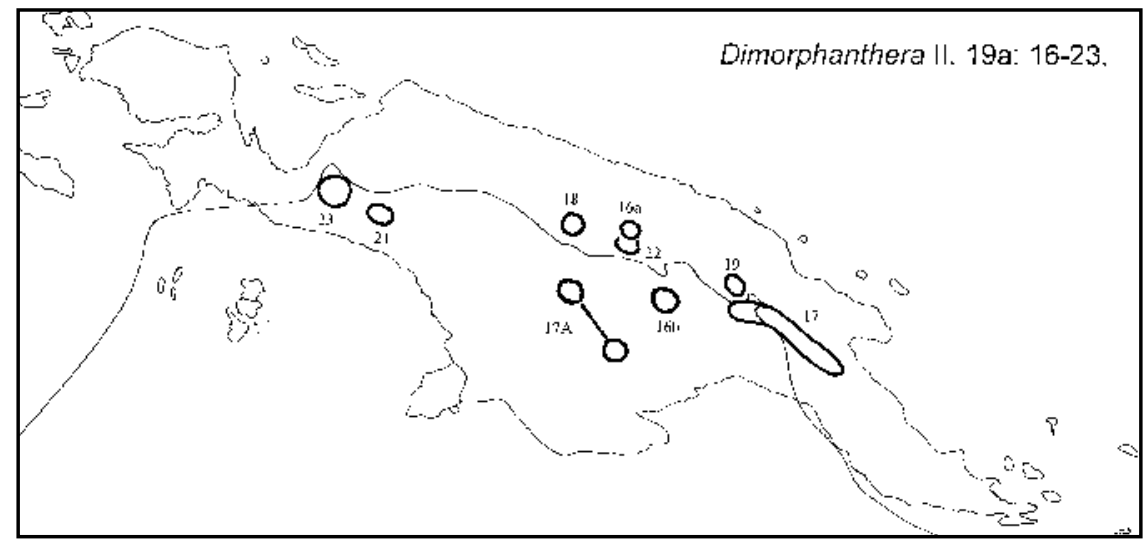

Fig. 70. Dimorphanthera II. 20 is included in 35.

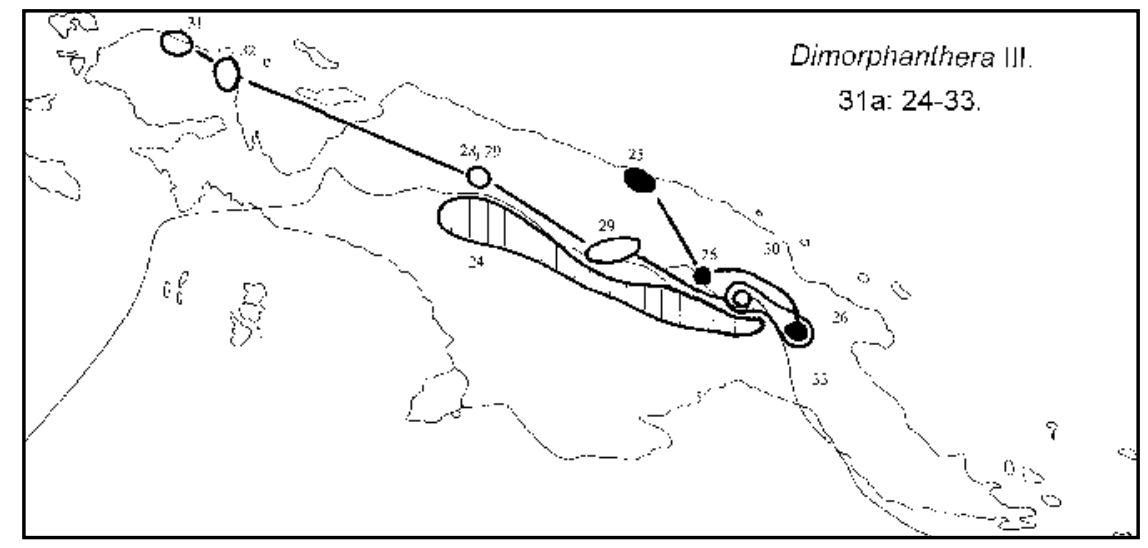

Fig. 71. Dimorphanthera III. 27 is included in 40. 


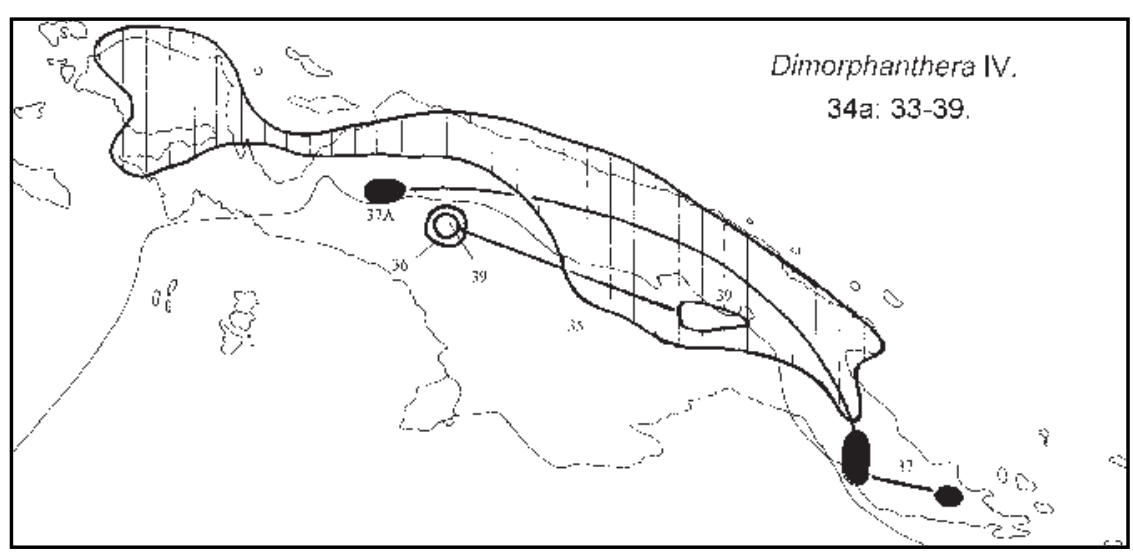

Fig. 72. Dimorphanthera IV. 37A is the reinstated D. alba J.J. Sm. Species 34 (and 20) are included in 35. Species 38 is a variety of 50 (Stevens 1974a).

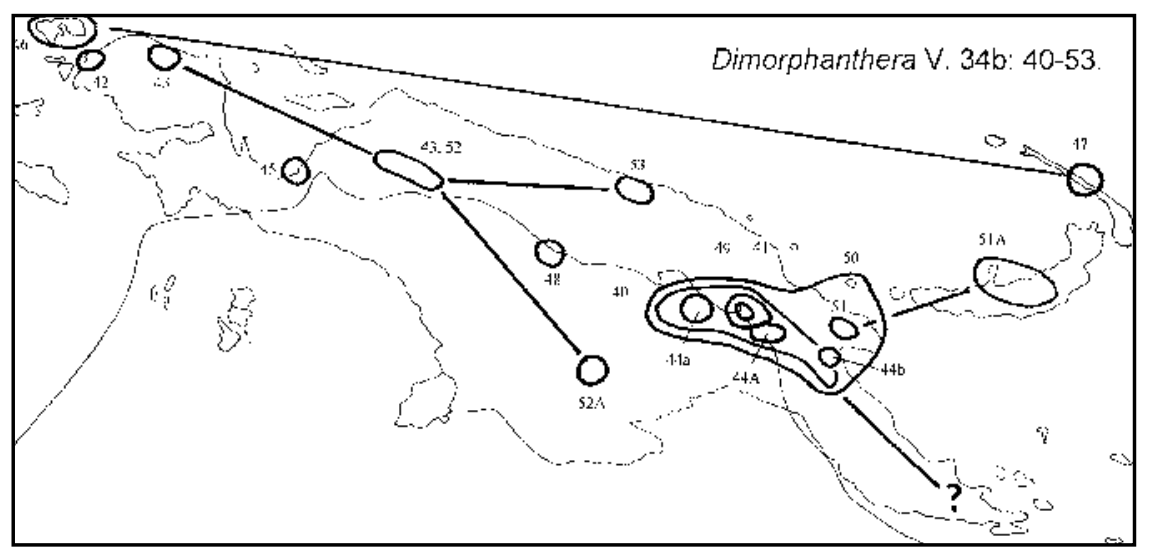

Fig. 73. Dimorphanthera V. $44 \mathrm{~A}$ is D. viridiflora Stevens. $44 \mathrm{~b}$ is $D$ womersleyi var. continua Stevens. 51A is D. bracteata Stevens. 52A is D. glauca Stevens.

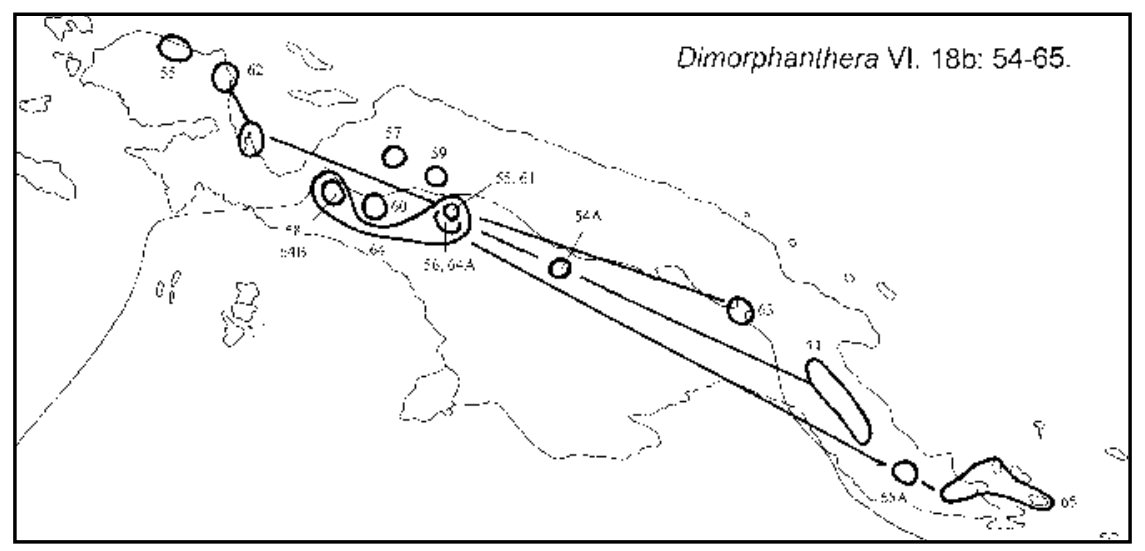

Fig. 74. Dimorphanthera VI. 


\section{Epacrids.}

The three Malesian Epacrid genera are all in tribe Styphelieae (Watson 1967).

Styphelia J.E.Sm. (Fig. 75). This ranges around the Riouw Pocket (including Riouw, Billiton, and Karimata Islands) like several other mangrove associates, and has a W Malesia - Cyclops terrane disjunction resembling that of Diplycosia V and Bracteata IX. The E PNG - Marianas group (subgen. Cyathodes (Lab.) Drude) is sister to the rest (subgen. Leucopogon (R.Br.) Drude).

Decatoca F.Muell. (Fig. 76). Finisterre and Owen Stanley terranes (cf. subgen. Cyathodes, last map).

Trochocarpa R.Br. (Fig. 76). New Guinea, Sulawesi, Borneo. (Decatoca and Trochocarpa are paired in Sleumer's key). 1-7 comprise T. subgen. Trochocarpa. Trochocarpa subgen. Pseudocyathodes Sleum. (8 and 9) is disjunct: (Arfak Mts. - Doormantop - central PNG (Mt. Hagen to Mt. Scratchley)). Trochocarpa is also in Queensland and New South Wales.

Both Styphelia and Decatoca/Trochocarpa are E Malesian. Also, both have close ties with Australia and the main massing of the subfamily, and in both a widespread Malesian group has its sister-group in SE Papua - unlike Rhododendron which usually has sister groups of widespread taxa in the west (Vaccinium has at least one in the east and one in the Philippines).

Epacrids are another Australasian group which is much more diverse in PNG than in Irian Jaya (twice as high at the subgeneric level). This pattern is also seen in groups such as birds-of-paradise (Heads 2001b). 'Asian' or 'Old World' groups (e.g. Rhododendron) are usually more diverse in Irian Jaya.

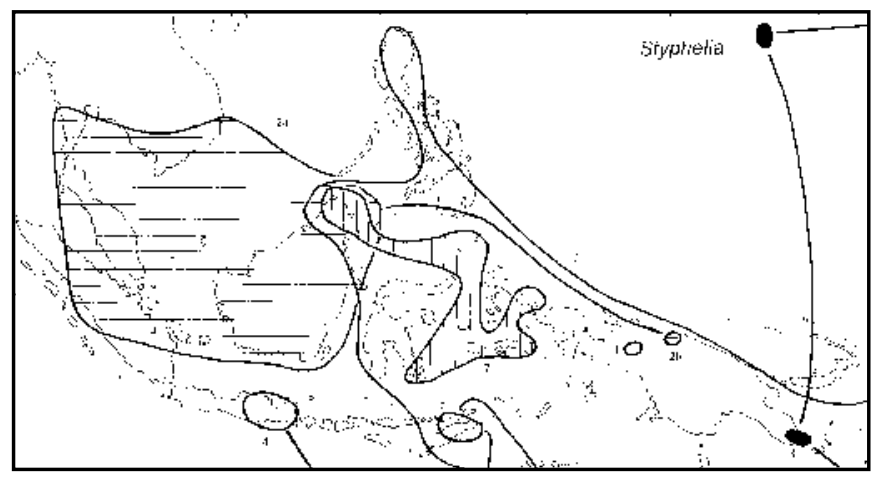

Fig. 75. Styphelia.

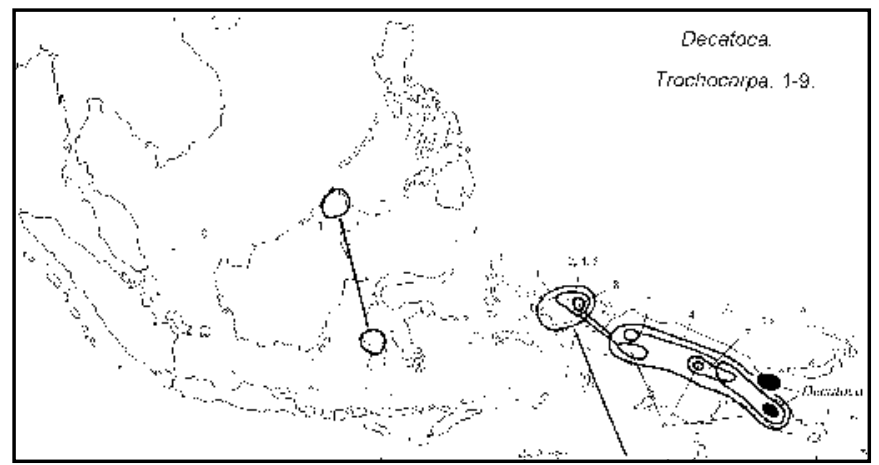

Fig. 76. Decatoca and Trochocarpa. 


\section{Biogeography of the Malesian mountain flora and the myth of long distance dispersal}

The dispersalist tradition of Holarctic centres of origin - the 'great evolutionary workshops of the north' - has dominated Australasian biogeography for over a century. A particularly well-preserved, well-explored and well-publicised fossil record in North America has meant that even today marsupials are assumed to have colonised Australasia and E Malesia from North America via South America and Antarctica. In other groups, Malesia/Australasia is supposed to have been invaded from the north directly, via Asia.

However, an alternative view has existed alongside the orthodoxy ever since biogeography came into existence as a global science. Already in the eighteenth century Willdenow (1798, cited in Weimarck 1934) was discussing biogeographic affinities between the Cape region of South Africa and Australia. This affinity among southern lands is totally unexpected in the orthodox explanation of dispersal from northern centres of origin. Because of the relationship between the floras Willdenow concluded that Australia and the Cape were once connected.

In an analysis of Borneo phytogeography, van Steenis (1964) referred to Hooker's idea of a 'continuous current of vegetation' between Scandinavia and Tasmania (e.g. Carex pyrenaica Wahl.: New Zealand - Pyrenees). In this 'current', Hooker observed that the Himalayan element (e.g. Rhododendron) stops abruptly in New Guinea, while going the other way the Antarctic element disappears more or less on the Bornean Alps (e.g. Kelleria Endl. (Thymel.)), or has very small numbers in Malaysia and SE Asia (e.g. epacrids). Likewise, van Steenis (1934b) observed that the rich region of Ericaceae (in the narrow sense) extends from the Himalayan-Chinese region through Borneo to New Guinea where it ends rather abruptly. Australia, especially, is surprisingly poor in Ericaceae sens. strict. Van Steenis wrote that 'This is a very peculiar phenomenon as there is hardly any climatic evidence which can be put forward to explain the absence of a rich Ericaceae flora in Queensland for instance ... . It is very peculiar that whereas Papua has a swarm of species Australia is so extremely poor in rhododendrons [only two species known], the more so as the dispersal of the minute seed must apparently go easily'. Further, the genus is very tolerant of the volcanic environment, and it is not immediately clear why are there no more species on, for example, Java, New Britain, or Bougainville, a high $(2743 \mathrm{~m})$, wet, volcanic island with only two species.

What is the reason for these globally significant breaks at New Guinea and Borneo? They are attributed here to vicariance at the origin of the groups, for example in the case of Ericaceae absent in Australia, the vicariance is with the epacrids. Vicariance developed naturally from the conclusions of van Steenis as he showed clearly that, first, the groups are much older than current topography, and second, that long distance dispersal is not an acceptable concept.

Van Steenis (1964) concluded that the array of mountain species on Kinabalu is a distinctly and essentially relict one, a fragment of what must have been there before, not necessarily on Kinabalu itself, but on the old mountains in its vicinity from which it derived its present flora.

Significantly, a few plants otherwise known only from Kinabalu are found on summits of lower, worn down ranges notably Kong Kemul in central east Borneo. Van Steenis cited plants such as Clethraceae; the Clethra species of eastern Borneo (Mt. Kinabalu, Mt. Murud (northernmost Sarawak) and Kemul (not cited by Sleumer 1971b), is related to plants on Palawan and Vogelkop-Wissel Lakes (Sleumer 1971b). 
Van Steenis (1964) concluded that 'not much can be added to Stapf's [1894] grand theory on the origin of the Malaysian mountain flora'. Stapf and Warburg's (1891) ideas on ancient mountain ranges in Malaysia were perhaps simplistic compared to modern geological ideas, and alpine plants may not actually need very high mountains, but van Steenis agreed with these authors in dismissing long distance dispersal and emphasising, instead, location and geological history. Later, van Steenis (1978a) even headed a section 'The myth of long-distance dispersal' and his whole approach to this subject was a major contribution to analytical biogeography.

The critique of 'dispersal' is counter-intuitive: Holloway and Hall (1998) wrote that 'To a geologist the dismissal of the role of dispersal seems bizarre'. It probably also seems bizarre to the layman, but is based on the simple observation that distribution of taxa and their means of dispersal show no correlation. The same distribution is held by many taxa with many different means of dispersal, while taxa with similar means of dispersal have quite different distributions. In his classic study of the Kinabalu flora, Stapf (1894) 'clearly showed the fallacy of invoking long distance dispersal' after finding no relation between size of range and dispersal mechanisms (van Steenis 1962b).

Van Steenis (1934b) argued that 'the effect of present dispersal can give no clue to an explanation of the present distribution of mountain plants in Malasia' and concluded (van Steenis 1936) 'there is no evidence that long distance dispersal has played a role in the origin of this flora ... On the whole I cannot trace any relation between distribution and what is known of [means of] dispersal'. (emphasis in the original).

If means of dispersal were important for establishing range, van Steenis (1964) reasoned, 'One would suppose that Radermachera ramiflora (Bignon.) with winged seed and the endemic species of Nepenthes and endemic orchids with dust seed would not be endemic on Kinabalu. [The Radermachera is closest to a Yunnan species]. Furthermore, plants with sympatric range and similar ecology often possess entirely different methods of dispersal, for example the conifer genus Phyllocladus Mirb. and the ferns Blechnum fraseri (A. Cunn.) Luerssen and B. fluviatile Salomon which occur in New Zealand, New Guinea, the Philippines and Kinabalu (the ferns extend to North Sumatra, Phyllocladus to Peninsular Malaysia). Moreover, strength of botanical affinities is often out of proportion with distances ... Finally the remarkable regularities in plant ranges and affinities of plants outlaw the idea of 'chance' dispersal otherwise than at very short distance.'

Writing on Malesian mountain plants in general, van Steenis (1934b) found that "The regularity of the plant invasion tracks is so well-pronounced ... that I can hardly attribute that to the rather irregular effect of typhoons', and 'The Malaysian mountain flora exhibits a rigid scheme of tracks which is opposed to any idea of randomness'. (van Steenis 1962a).

Kalkman (1979) was rather sceptical of what he called the 'anecdotic' view that there is no correlation between distribution and means of dispersal. He undertook a much larger analysis than any done previously, including just over 3000 species from the Flora Malesiana. Apart from a correlation in a small number of species, he felt the conclusion must be, at least for the time being, that the dispersal method is of subordinate importance for areogenesis ... On the other hand, I still cannot quite accept that dispersal efficiency ... would not be mirrored in the areas covered by the species if the sample taken is large enough'. However, the facts again are clear enough, although perhaps unexpected. 
Van Steenis's (1934b) conclusions agreed with those of Stapf (1894), as indicated, and also contemporary authors such as Lam (1929), who felt the distribution of Papuan mountain plants 'to some extent cannot be explained in another way than by reference to historic plant geography.' Lam's (1930) prescient synthesis of Wegener's geological ideas and plant geography has been overlooked by American plant geographers since they 'rediscovered' continental drift in the 1960s-1970s. Likewise, Skottsberg (1940) concluded that the alpine plants of Hawaii or their ancestors 'antedate the formation of the volcanoes which are their present home', and Ridley (1930) wrote that it is 'impossible' that the connection between the mountain floras of the Peninsula Malaysia and Kinabalu can be explained by seed being blown across the South China Sea. Instead, these two areas and their floras are relics of a once more continuous region. Symington (1936) agreed with Ridley that dispersal between Peninsular Malaysia and Kinabalu by wind, water etc. is 'much more difficult to credit than the, perhaps less obvious, relic hypothesis ... To explain these relics it is probably necessary to go back to Cretaceous times ...'.

Discussing Ericaceae of South America and tropical Africa, Stevens (1970) agreed with van Steenis' critique of long distance dispersal: 'plants can disperse from one old almost eroded-away mountain to another younger one, so the age of taxa inhabiting isolated mountains and mountain systems may bear no relation to the age of the physiographic features themselves.'

Thus in contrast with the ideas of the dispersalist school, as expressed mainly in the writings of temperate botanists, tropical botanists have often taken a more critical look at 'dispersal'.

The view that distributions reflect non-random processes leads to critical analysis of the distributions themselves, ecology, evolution, systematics and paleogeography. Van Steenis (1964) wrote: 'It is surely a miracle that some [Malesian mountain species] like Euphrasia and Haloragis micrantha still bear testimony of the ancient pathway ... we can easily deduce that temperate taxa could only survive by transfer from decaying mountains and ranges to new ones coming up.... From this it follows that many plant taxa will be older than the bedrock of the mountains on which they are now found'. This is a very important process, although mountains can also inherit biota from lower land in situ (see below), as 'mountain plants' do not always need mountains to survive. Van Steenis gave an example: 'The Snow Mountains [Irian Jaya] of possible Pliocene uplift must have received their alpine flora from another, older higher range in decay, probably along the northern Papuan coast'.

Kinabalu is an anomaly, the youngest exposed granite intrusion in the world, uplifted very rapidly just 1-2 million years ago. As it rose it would have inherited flora from the Crocker Range through which it burst. Although the Crocker Range is now less than $1000 \mathrm{~m}$ high, Meijer (1974) wrote that during the Miocene (7 Ma) it was part of a much higher range which had a temperate conifer belt above a subtropical forest zone. The sediments comprising the Crocker Range were themselves deposited and uplifted 15-5 million years ago, and as they rose would have inherited local flora and fauna from any adjacent land, details of which are by now largely lost from the geological record.

Corner (1964) gave the following sequence: 1. L. Cretaceous - Eocene: deposition of alluvial 'geosynclinal' strata (Wariu Formation) which later became the base of Kinabalu; 2. Oligocene (35 Ma): first emersion of the Wariu Formation; 3. Pliocene (11-9 Ma): intrusion of granodiorite; 4. Mid-Pliocene: emersion of the batholith. 
Meijer (1974) described the 185 species in the lower montane tree flora of Kinabalu and concluded that: 'the ecological plant geographical potential of such a mountain flora is certainly great - it contains plants adapted to acid sandy podsolic soil ... Some of these plants are not very sensitive to high temperatures, and can live as well at sea-level. In fact they are as much a part of the coastal sandy forests and peat swamps as of the submontane flora.' Meijer cited as examples Vaccinium bancanum and species in Agathis, Tristania and Xanthophyllum. In addition to 'geographical potential', the survival potential of this flora is great enough to allow its persistence more or less in situ, highly modified of course, through several generations of mountain building and erosion.

In this view, features such as the centres and breaks in distribution in Borneo and New Guinea cited above are explained primarily by vicariance and accretion, as mediated by tectonics. In another example, there is a sharp floristic demarcation between Taiwan and Luzon, with the very rich conifer flora of Taiwan quite different from that of Luzon-Borneo, Van Steenis (1964) presented this 'remarkable relation' as an 'unsolved problem'. A major break in Sulawesi constitutes what van Steenis (1972) called 'another problem for the geologists': the existence of a floristic boundary between South and Central Sulawesi. Van Steenis (1936) observed that, the number of typical New Guinea track plants is much higher in the Central Sulawesi Latimodjong Range compared with Mount Bonthain in the south. Conversely, of 150 mountain species of Java, 80 occur in the Lesser Sunda Islands, and no fewer than 50 are also found on Bonthain volcano, while none occurs on the Latimodjong Range [S Central Sulawesi].

In practice, the concept of dispersal - the process giving rise to distribution - as physical movement due to 'means of dispersal' (rather than evolution of earth and life together) has only lead to endless, desultory debate. For example, Stevens (1981) noted that only three species of Rhododendron occur south and east of New Guinea, 'although there is no obvious ecogeographic reason for such an abrupt cut-off ... Hence it seems reasonable to postulate movement from west to east through Malesia.' (cf. Irving and Hebda 1993). However, Specht and Womersley (1979) observed that about half the species of the section Vireya are in New Guinea, and so Vireya 'must have developed on the Australasian tectonic plate and then migrated into the Malay Archipelago when the two areas became contiguous in the late Miocene' - the exact opposite of what Stevens decided.

Through the 1980s long distance dispersal made an insidious return with the rise of the non-systematics-based ecologists who were probably unfamiliar with most of the data that van Steenis and the others had worked with. For example, Cain et al. (2000) studied long-distance dispersal in plants and concluded, predictably enough, that more observations are needed and that genetic methods should be applied. However, Veldkamp (2001) noted that in this paper 'curiously, van Steenis's many arguments against [long distance dispersal] are nowhere mentioned'. There seems to have been a loss of hard-won knowledge over a single generation. The critique of dispersal was one of the few things that the great tropical botanists Corner, Croizat and van Steenis all agreed on, and their views should at least be cited in discussion of a problem which is clearly and unfortunately still not resolved.

The long distance dispersal hypothesis continues to attract criticism from many different fields. In molecular studies, for example, Füchter (2001) supported the nunatak hypothesis of survival of European flora during glaciation, often supposed to 'wipe clean' a region. Disjunctions in Malesian vascular plants were discussed by Baker et al. (1998) who concluded that these 'probably require a tectonic explanation'. Likewise, Tan (1998) suggested that disjunctions in Malesian mosses 'can now be better explained by relating them to local plate tectonic movements than by the long-distance dispersal hypothesis', and 'the majority of Malesian species of mosses ... have evolved in situ during the geological formation of the various island groups, notably Borneo and New Guinea.' 
Studies of the palms illustrate the differences between dispersal and vicariance analyses.

Hahn and Sytsma (1999) treated Caryota in three main clades. The geographic pattern is clear and simple: the rumphiana clade (southern India, Sri Lanka, Borneo, E Malesia) and the mitis clade (SE Asia, W Malesia) are sisters, and overlap on Borneo and Sulawesi, whereas the rumphiana clade and the basal maxima clade (SE Asia, Sumatra, Java) are precise geographic vicariants, with the latter sandwiched between the disjunct locations of the former. Although Hahn and Soltis observed accurately that 'Broad patterns of relationship among the three principal clades correlate well with vicariance coupled with the geologic history of SE Asia', they did not actually describe the vicariant pattern, or observe that it does not occur between sister groups. Instead, they gave a lengthy discussion of Huxley's Line and two versions of Wallace's Line, none of which coincide with either the western or eastern boundaries of any of the three clades. They could have mentioned the precise vicariance that is actually in evidence between two of the three clades, which does not lie along the famous lines but along the boundary between the Peninsular Malaysia, Sumatra and Java on one hand, and Borneo on the other.

Authors often invoke chance dispersal to explain what they feel to be anomalous distributions. Hahn and Sytsma (1999) are no exceptions and immediately after correlating the origin of the principal clades with vicariance and geology, they proposed a 'general model' for the genus in which it migrated from a centre of origin in (presumably mainland) SE Asia eastwards through Malesia. No reason for this is offered apart from the fact that previous authorities have suggested it.

In fact the major Borneo-Java break in Caryota is a standard one seen in very many Ericaceae and other organisms. For example, in areas such as Indonesia with strong ocean currents, it has usually been assumed that populations of coral reef organisms with pelagic larvae will be genetically connected and interbreeding. However, among populations of a mantis shrimp from 11 reefs in Indonesia, Barber et al. described 'southern' and 'northern' clades in the Java and Flores Seas, which 'may be relics of [respectively] Indian and Pacific Ocean populations' like the Malesian Ericaceae.

Although Hahn and Sytsma (1999) concluded overall in the usual way, supporting 'a combination of vicariance and dispersal', no evidence for 'dispersal' is given, apart from supposed 'anomalies' of distribution. Instead of focusing on the actual patterns of distribution and phylogeny the authors centred their discussion around Wallace's and Huxley's Lines, that are famous but not relevant, and on what some other authors have said about palm dispersal. In the last paragraph Hahn and Sytsma drop their initial, radical idea of broad patterns of relationship being correlated with vicariance and geology, and suggest that, after all, 'dispersal has played a very large role' in the evolution of the genus.

In contrast with Hahn and Sytsma's (1999) approach, Corner (1966) regarded panbiogeography as 'the most positive contribution to palm biogeography', and Rodd (1998) interpreted another palm genus in the area, Livistona R. Br., simply in terms of vicariance. This genus has most species in Australia and ranges through the Solomon Islands and Malesia to Japan and Assam. There is also a disjunct population in NE Africa. Rodd (1998) argued against Miocene dispersal, as 'this rather brief time scale hardly seems sufficient to account for the great diversity of form found in Australian Livistona, especially when taken in conjunction with the concentration of most of the species in refugia often associated with far more ancient land surfaces'. Rodd proposed as an alternative 'that proto-Livistona had already emerged by the time Laurasia and Gondwana began to separate'. As further support, Rodd cited the biogeography and Upper Cretaceous fossils already attributable to the modern, morphologically specialized palm genus Sabal Adans. 


\section{Biogeography of regions in Malesia}

\section{Mentawei Islands}

These islands lie $100 \mathrm{~km}$ off Aceh and central Sumatra and are an important centre for many groups. 22: Vaccinium acuminatissimum forma ellipticum (J.J.S.) Sleum., is endemic to Simalur and Sipora Is. Sumatra has nine endemic mammal species (including one primate), while the Mentawei Islands have 11 endemics, including four primates. The biogeographic status of these islands is probably related to their position in the Indian Ocean. The following examples are taken from bird data (Howard and Moore 1984), the best-known of any group and invaluable for resolving most biogeographic problems.

The parakeet genus Psittacula ranges in a northern Indian Ocean triangle: Sudan/Somalia - Afghanistan/Tibet - Borneo, with endemic species on Sri Lanka, Mauritius etc. Psittacula alexandri is disjunct between north India/southern China/Indochina and Java/Bali, and although absent from Sumatra, is present on the Andaman and Mentawei Islands (Simalur, Lasia and Babi, and Nias), skirting Sumatra to the west.

Borneo is held with Psittacula longicauda, with one widespread subspecies on Sumatra, Malaysia and Borneo, and endemic subspecies on each of Andaman Is., Nicobar Is., Mentawei Is. (Enggano), and Riau and Natuna (Bunguran) Islands. The island subspecies would usually be assumed to have been derived by 'chance dispersal' from the mainland to the islands followed by 'peripheral isolation'. Here they, along with P. alexandri and the Mauritius and Sri Lanka species, are taken to represent relics of the former Indian Ocean/Riouw Pocket base from which the mainlands, as they took shape, were invaded.

The nightjar Europodus macrotis has subspecies at: Assam to W. China, Indochina and N Malaysia; S India; Mentawei Is. (Simalur I.); Philippines; and Sulawesi. Here the connection S India - Mentawei Islands is likely, while Sumatra and Java are not involved. The related E. temminckii is in Malaysia, Sumatra, and Borneo.

Distributional arcs skirting Sumatra to the west are well-known in other birds (Treron pigeons, Fig. 77), cf. Hemiprocne longipennis thoa: Batu I, Pagi Is., Enggano I., possibly Halcyon chloris chloroptera 'West Sumatran Is.'; and plants (Phaleria Jack., Ding Hou 1960). Citronella D. Don is disjunct between Simalur I. and Java (Sleumer 1971a), recalling Chisocheton aenigmaticus D.J.Mabberley endemic to Simalur I., but apparently related to New Guinea species (Mabberley 1979),

\section{Aceh}

For Sumatra, Whitten et al. (1987) wrote that 'perhaps the most surprising zoogeographic boundary, because it is not obviously caused by a river or a strait, is that which runs SW /NE through Lake Toba [just south of the Aceh border]. Seventeen bird species are found only to the north of Lake Toba and ten only to the south.' Three mammals (including the orang-utan) occur only in the much smaller area to the north (Aceh), four only to the south.

The geological map shown above (Fig. 6, from Metcalfe 2001) shows the part of Aceh west of the Sumatra fault as comprising the Sikuleh terrane, occurring to the north of the Natal terrane. These two are more or less equivalent to the Aceh and Mentawai microplates of Malod and Kemal (1996), bounded in the west by the Mentawai fault.

Absences are often neglected in systematic studies and not properly documented, but they contribute to the phenomena seen at a biogeographic node. For example, Gillett (1974) observed 'significant voids' in the distribution of Melanesian Cyrtandra and referred to the 'paradox' of these absences. Danser (1928) wrote that 'it seems strange' that Nepenthes does not occur in the northern part of Sumatra (Aceh, according to his 
map). Danser suggested that with more collecting it may prove to occur there, but Cheek and Jebb (2001) recently wrote that the genus is still not known in the 'northern tip' of Sumatra. As Nepenthes is most diverse in W. Malesia, with dozens of species in secondary, swamp, and heath forest as well as montane habitats, and also occurs in Sri Lanka and NE India, its absence from Aceh has all the hallmarks of a 'significant void'.

Taxa of Aceh, especially the Gajo Lands (Mt. Losir etc.) in central Aceh, show important biogeographic connections with Madagascar and Sri Lanka. Direct (disjunct) ties with Himalaya/N Burma/Yunnan $2000 \mathrm{~km}$ to the north are shown in Gaultheria. A similar example from timber trees is Terminalia myriocarpa Heurck \& Müll. Arg. (Combret.), known from NE India, Upper Burma and Yunnan, and also in Aceh (Gajo Lands) (Exell 1954).

Aceh - New Guinea connections are very important in Ericaceae, e.g. Pseudovireya I and II. Van Steenis (1964) noted that a small but distinct set of Australia-New Zealand high-mountain taxa is found as an outlier on the ancient Losir massif. Examples include Oreobolus R.Br. (Cyperaceae) (Fig. 120, here and Peninsular Malaysia, Kinabalu, Sulawesi, New Guinea, and around the Pacific); Centrolepis (Centrolepid.); Patersonia R. Br. (Irid.), and Monostachya Merr. (Gramineae: Losir, Philippines, New Guinea). This pattern represents a classic biogeographic 'problem' (van Steenis 1964) as long distance dispersal seems such an unlikely explanation. The pattern is also seen in the many N Sumatra - New Guinea disjunctions in Ericaceae and others; Schouten and Veldkamp (1985) described this disjunction in the following:

Anthoxanthum horsfieldii. In this species the populations from N Sumatra and New Guinea (from Mt. Carstensz to Mt. Dayman) are 'especially close.'

Agrostis infirma Buse. In this species a variety found in Sumatra, Java and New Guinea 'clasps' the ones on the islands in between (Veldkamp 1982) (Fig. 78).

Centrolepis fascicularis is in Sumatra, and disjunct in New Guinea (Wissel Lakes, Lake Habbema, Mt. Suckling) and Australia.

Schouten and Veldkamp concluded their discussion with the query: 'Why does it seem as if a taxon can 'jump' from New Guinea to Sumatra and is then, once there, apparently unable to disperse further along the Bukit Barisan?'

Other N Sumatra - New Guinea disjunctions are seen in Lindsaea (Fig. 79), Podocarpaceae (Fig. 80), Rhopaloblaste (Palmae) (Fig. 81), Grammitis ornatissimum (Fig. 82), Papuama (Diptera) (Fig. 83) and Grammitis padangense (Fig. 84), the last also on Mt. Kinabalu and Mt. Apo. Canarium hirsutum and allies (Burser.) (Fig. 85) show a related pattern, with one species widespread through Malesia and the others in Sumatra/Peninsular Malaysia and in New Guinea.

Central W Sumatra is biogeographically closely related to Aceh and like Aceh is also an important site of disjunction. Nepenthes sumatrana (Miq.) Beck, endemic there, is 'remarkably similar' to N. treubiana Warb, of New Guinea (Check and Jebb 2001). (Danser, 1929, included the former in the latter).

Impatiens L. (Balsamin.) is widespread globally and in Sumatra has 29 species, most of which are local endemics in the montane forest (Grey-Wilson 1989). This occurs along the entire western seaboard of Sumatra, where a long series of active and extinct volcanoes set within the rift of a chain of more ancient mountains provides sufficient altitude for a rich flora. Apart from one widespread species, Aceh has 8 species of Impatiens, North Sumatra 6, West Sumatra 13, Bengkulu 2, South Sumatra 5, and Lampung 1. The maximum number is in West Sumatra (especially Mt. Kerinci which has three endemic species and one variety). Red-flowered species occur only on a standard track: Africa, Madagascar, Sri Lanka, southern India and Aceh. 


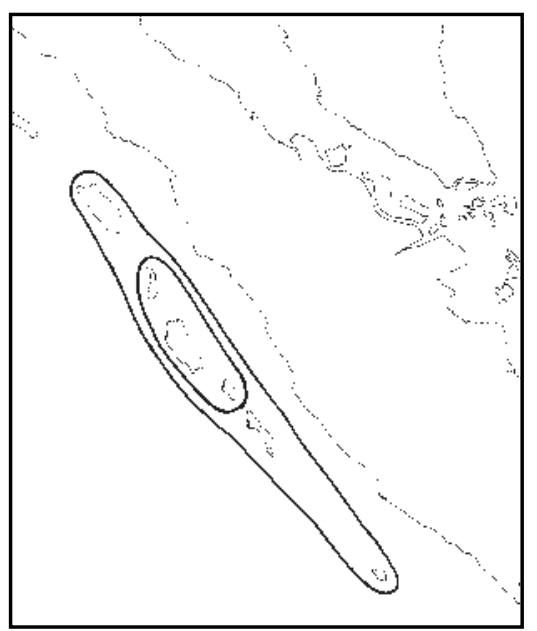

Fig. 77. The green pigeons Treron curvirostra smicra (central) and T. vernans mesochloa (more widespread) (Columbidae) (Howard and Moore 1984).

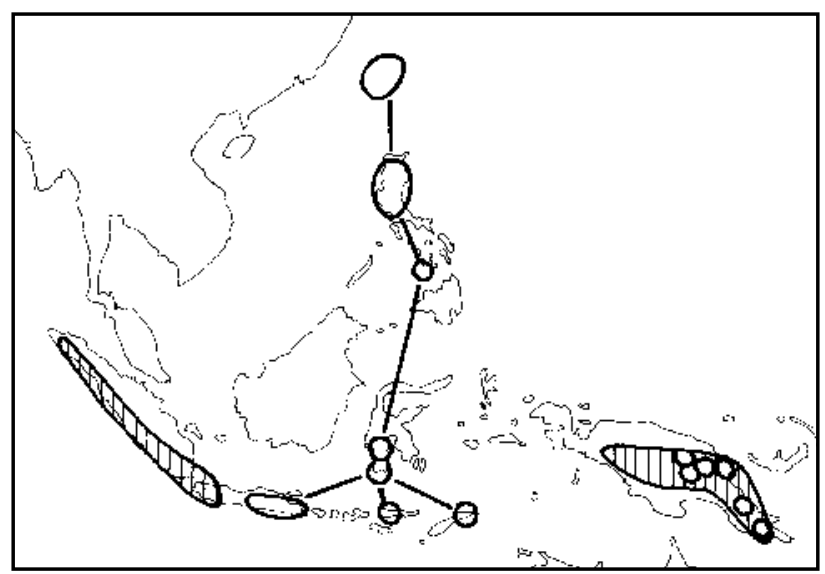

Fig. 78. Agrostis infirma Buse var. infirma and var. remota (Buse) Veldk. (hatched), (Gramineae) (Veldkamp pers. comm.; the two varieties were cited in Veldkamp 1982 as 'A. rigidula Steudel var. rigidula' and 'var. remota (Buse) Hoynck \& Linden').

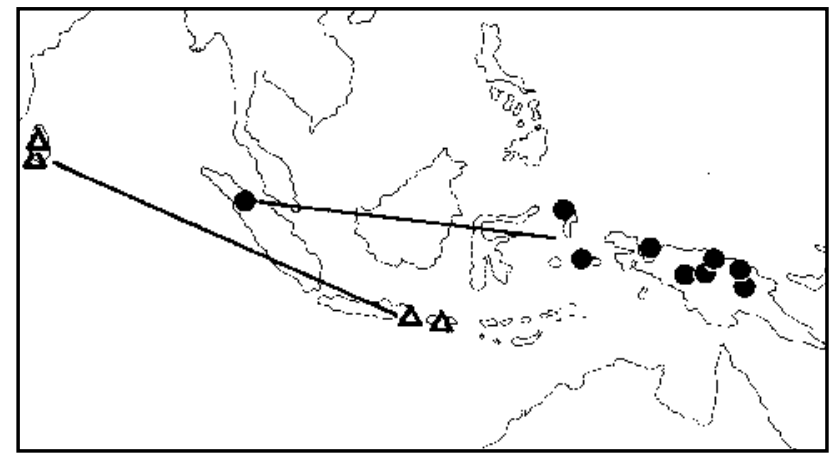

Fig. 79. Lindsaea werneri Rosenstock (circles) and L. glandulifera v.A.v.R. (triangles) (Dennstaedt.) (Kramer 1971). 


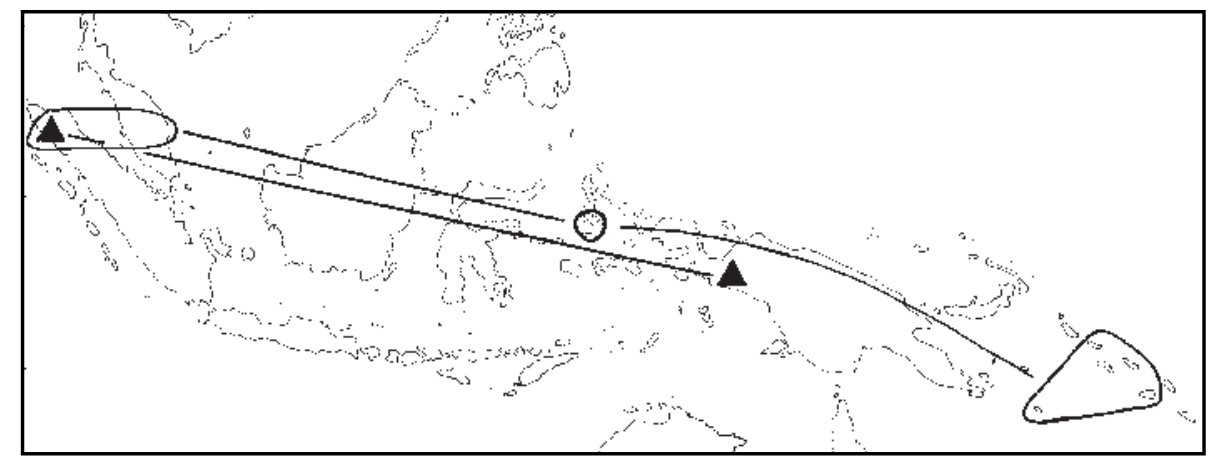

Fig. 80. Podocarpus atjehensis (triangles); Dacrydium medium de Laub. (Sumatra, Peninsular Malaysia) and its sister species D. magnum de Laub. (Moluccas, Solomon Is.) (de Laubenfels 1988).

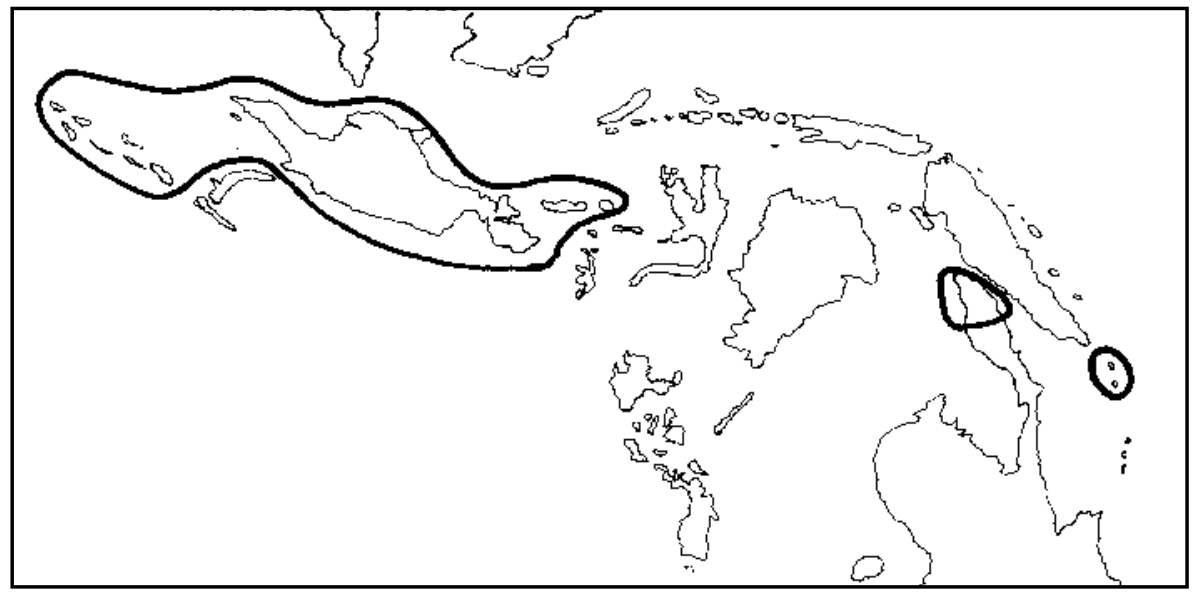

Fig. 81. Rhopaloblaste Scheff. (Palmae) (Baker et al. 1998).

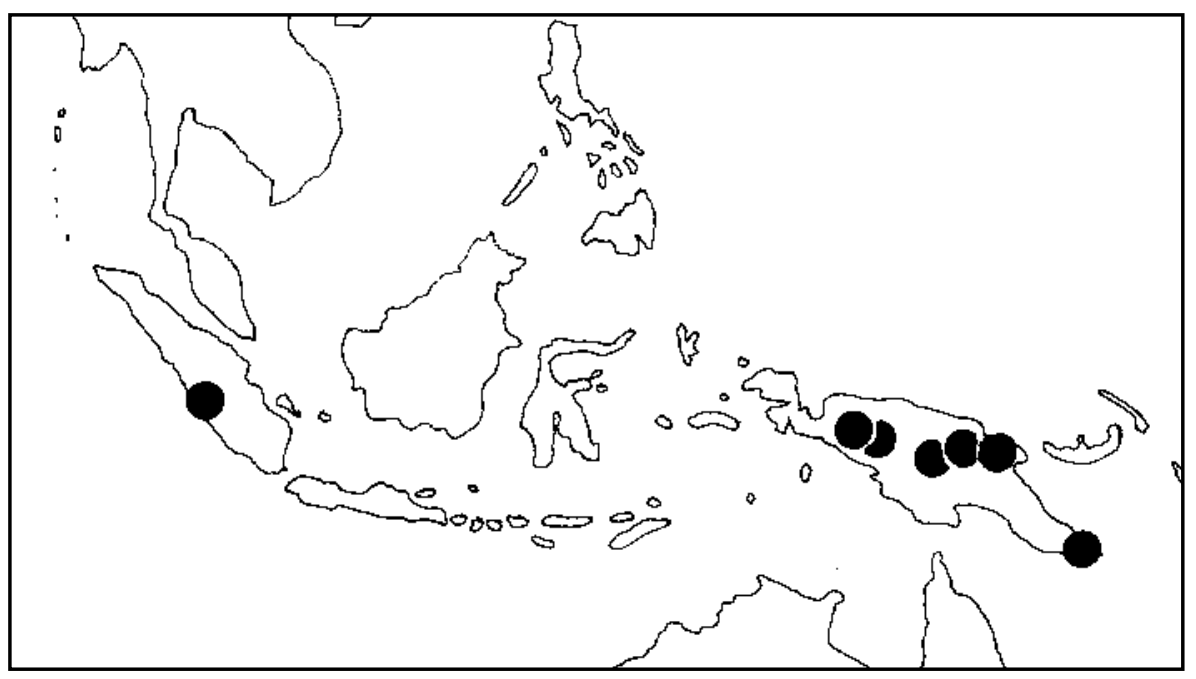

Fig. 82. Grammitis ornatissismum Rosenst. (Grammitid.) (Parris 1983). 


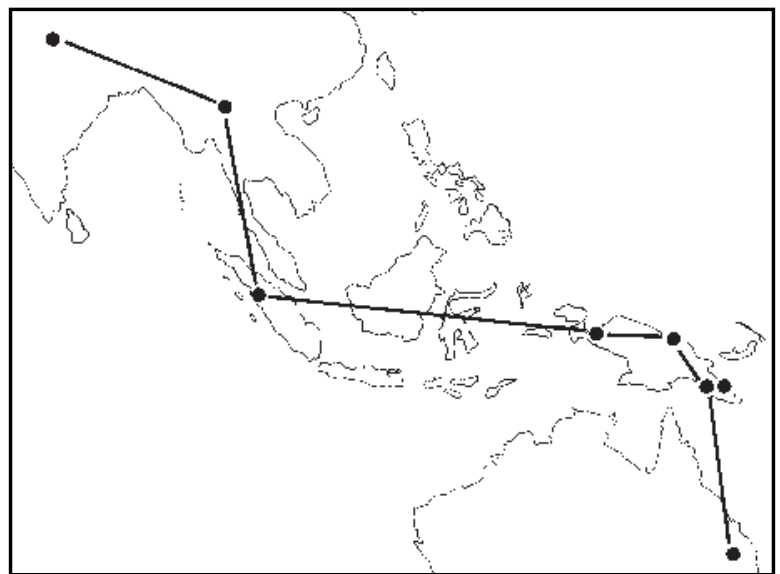

Fig. 83. Papuama Mathis and Zatwarnicki (Diptera: Ephydridae) (Mathis and Zatwarnicki 2002).

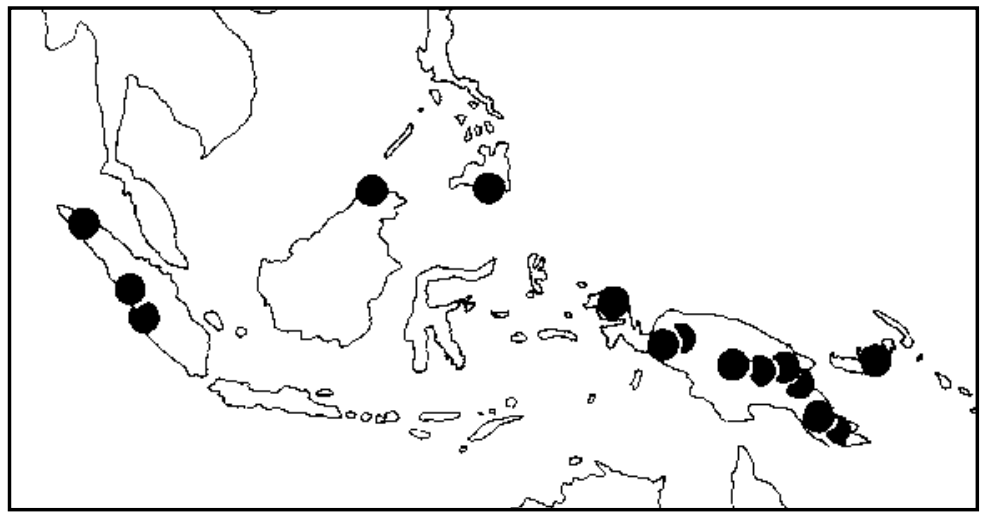

Fig. 84. Grammitis padangense Baker (Grammitid.) (Parris 1983).

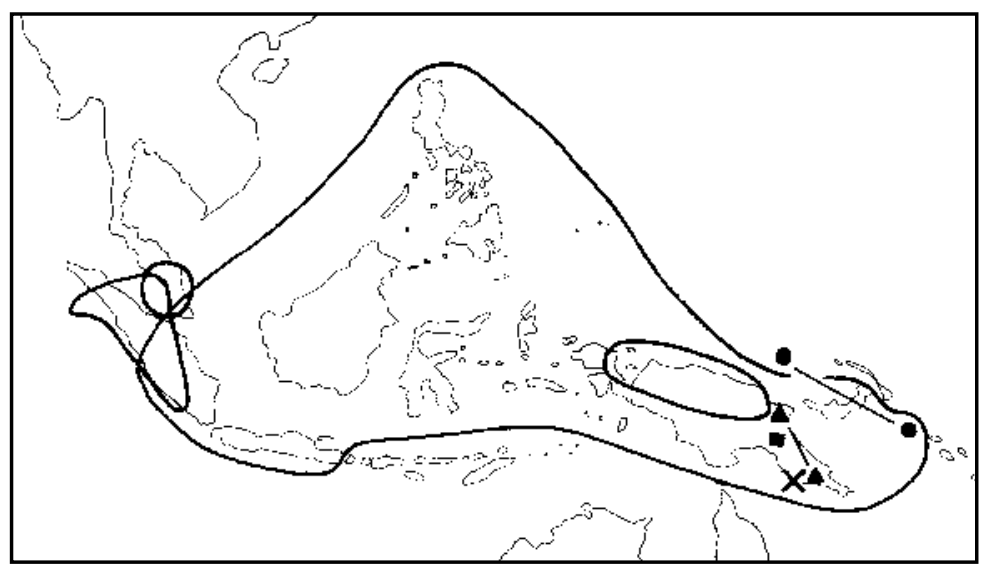

Fig. 85. Canarium hirsutum and allies (Burser.) (Leenhouts et al. 1956). Note the concentration of species in the far west and east of Malesia, and the suggestion of parallel arcs in Papua New Guinea. 
Impatiens eubotrya Miq. of West Sumatra and I. steenisii Grey-Wilson of Aceh have a bilaterally assymmetrical corolla lip, and are closely allied, not with other Sumatran plants, but with a group of species centred on the Himalayas, Burma, Assam, and Yunnan. This disjunction recalls that seen in Gaultheria and others.

Describing a related disjunction, Ding Hou (1964) wrote 'it is rather remarkable' that Euonymus benguetensis Merr. (Celastr.), is known only from Central Sumatra (Mt. Kerinci) and Luzon. However, this track is vicariant with the species keyed with E. benguetensis, E. japonicus, which also runs between CW Sumatra and Luzon (and points north), but instead of a direct connection occurs through Java and Sulawesi. E. javanicus also largely surrounds Borneo, and is present there only in the N Meratus Mts. (Fig. 114). E. acuminifolius (forests $700 \mathrm{~m}-3200 \mathrm{~m}$ ) is only known from CW Sumatra, Kinabalu, and SW Sulawesi, again, largely surrounding Borneo and this time present there only at Kinabalu.

The E. benguetensis track (Central/North Sumatra - Luzon) is also seen in several Ericaceae affinities (Rhododendron ser. Javanica III, Diplycosia III, Vaccinium sect. Bracteata XV, and cf. Bracteata X). Likewise, Norrisia Gardn. (Logan.) consists of two species: N. malaccensis is in CW Sumtra/Peninsular Malaysia and Philippines (Suibuyan/Mindanao), its vicariant N. major fills the gap in southern Sumatra and Borneo (Leenhouts 1962).

West Sumatra - Philippines connections skirting W Borneo are seen in taxa such as Xanthophytum ferrugineum (Rub.) (Axelius 1990) (Fig. 86).

In southwest Sumatra, species in Rhododendron subsect. Albovireya show an interesting pattern of disjunctions which may have been caused by dextral transcurrent movement along the Sumatra fault. This massive fracture runs along the entire length of west Sumatra following the active volcanic arc (Hall 1998). Detailed mapping of the species in relation to the fault is needed.

West Sumatra includes arc and ophiolitic material accreted in the Cretaceous (Hall 1998).

\section{Peninsular Malaysia}

Like N. Sumatra, Peninsular Malaysia shows disjunctions with E. Malesia. Podocarpus spathoides (Podocarp.) (Fig. 87) ranges in Penisular Malaysia (Mt. Ophir) - Rossel Is.: these populations have buds half the length of the remaining two populations: N. Moluccas (Morotai) - Solomon Islands (de Laubenfels 1989). Parsonsia curvisepala (Apocyn.) (Fig. 89) is a widespread, well-collected species in Peninsular Malaysia and E Malesia but is not in Borneo, W. Philippines, or N. Sulawesi (Middleton 1991).

Bruguiera hainesii C.G. Rogers (Rhizoph., dry side or inland of mangrove) is found along the Burma and Thailand coast to Peninsular Malaysia, with a disjunct population in Papua (Ding Hou 1958, Percival and Womersley 1975). Other species are widespread through Malesia.

Leptocarpus R. Br. (Restion.) is disjunct in Malesia between Hainan, Cambodia and Peninsular Malaysia (one species) and Aru I. and southern New Guinea (two species). Elsewhere (Heads 1985a) this was shown to be one of many groups which cross Wallace's Line, but not as the result of chance dispersal.

In animals, the Ponera taipingensis species group (Hymenoptera: Formicidae) has a single species in each of Peninsular Malaysia, Papua New Guinea, and Fiji, and two in Samoa (Fig. 88) (Taylor 1967). 


\section{Riouw Pocket}

The Riouw Pocket (Corner 1938, 1960, 1978a) includes SE Sumatra (Riau, Jambi and Sumatera Provinces), south Johore, the SW corner of Borneo, and the islands in the region (Riouw, Lingga, Bangka and Billiton). Corner noted the strange absence here of several otherwise very widespread plants (e.g. Ficus tinctoria, near mangrove, on coral rock etc.; F. subulata, related to the last but in rainforest, shade-loving, often epiphytic; F. fulva, F. glabberima, F. parietalis, F. uniglandulosa, F. hispida), but also the presence there of many range-restricted taxa (F. deltoidea var. deltoidea, F. d. var ovoidea, F. microstoma, F. acamptophylla Miq., F. microsice Ridley, Tristaniopsis sp., Pandanus corneri). Ancistrocladus tectorius (Fig. 90) in Malesia is largely restricted to the Riouw Pocket. An example of local endemism is Indovethia Boerl. (Ochn.), Central East Sumatra (Riouw Province), westernmost Kalimantan and Sarawak (1st Div.) (Kanis 1971). This is a rare lowland monotype recorded from the edge of a lake and above a torrent in forest. Gonystylus bancanus (Thymel.) (Fig. 91) is the most valuable timber tree in the area and also an endemic. Likewise the bird Setornis (Pycnonotidae) is only known from E. Sumatra, Bangka I. and Borneo.

As many as 57 species of dipterocarp reach their eastward or westward limit at the Lupar R. (by Kuching) Ashton 1969, Corner 1978a), at the boundary of the Riouw Pocket. The Semitau terrane (Fig. 6) occupies the Kuching corner of Borneo, and is bounded in the north by the Lupar suture (like the dipterocarps) and in the south by the Boyan suture, dated at Late Cretaceous (Metcalfe 1998). Hutchison (1996) and Morley (2002) provided more data on the tectonics of the 'Lupar Line'.

The incense tree Aetoxylon Airy Shaw (Thymel.) was known to Airy Shaw (1953) only from 1-200 km around Kuching. Riouw pocket disjunctions include those of Nephthytis Schott (Araceae), known only from tropical West Africa and near Bintulu in central W. Sarawak (Hay et al. 1994). Gymnanthes Sw. (Euphorb.) occurs around the Riouw pocket (widespread in Borneo, especially the west) and is also in Cameroun/Congo and America (Esser 1999). Lindsaea walkerae (Kramer 1971) (Fig. 92) shows both Riouw Pocket - Sri Lanka and Riouw Pocket - Vogelkop disjunctions.

In a broader sense the Riouw Pocket involves most of Sumatra and west Borneo. Aralidium Miq. (Aralid.), Pentastemona Steenis (Pentastemon.), Scaphocalyx Ridley (Flacourt.) and Scyphostegia Stapf (Flacourt.) are all W. Malesia endemics from here, centred on the Riouw pocket. The last two have morphologically challenging flowers. Van Heel (1973) observed that the unique ovary of Scaphocalyx, with two radially alternating whorls of ovules one above the other, cannot be understood under the classical theory of the carpel as a modified leaf (like heretical 'sterile carpels' in Styphelia; Paterson, 1961). The seed of Scaphocalyx has features (nucellar beak, threelayered testa etc.) that are frequent in gymnosperms, but rare in angiosperms, indicating that the Riouw pocket may act as a centre of relictual characters. The morphogenetic significance of Scyphostegia, with structures intermediate between ovule and ovary (and 'blossoms' intermediate between flower and inflorescence), has been discussed elsewhere (Heads 1984).

Michaux (1995) analysed the biogeography of 384 Borneo vertebrates and invertebrates, and interpreted their distribution in terms of West Malesian geological terranes. His 'Pattern 3', numerically the most strongly defined, is identical to Corner's (1978a) Riouw Pocket and also the East Malaya terrane (as mapped by Michaux 1995).

A good example of the Riouw pocket avoided by a mangrove associate is Sauropus bacciformis (L.) Airy Shaw (Euphorb.) ('along or near beaches ... along path through mangrove ... tidal flats, open waste ground' etc. ) (van Welzen, in press). This largely vicariates with other Euphorbiaceae such as Neoscortechinia philippinensis (Merr.) van Welzen (freshwater swamp forest, along mangrove etc.) which invades the lands 


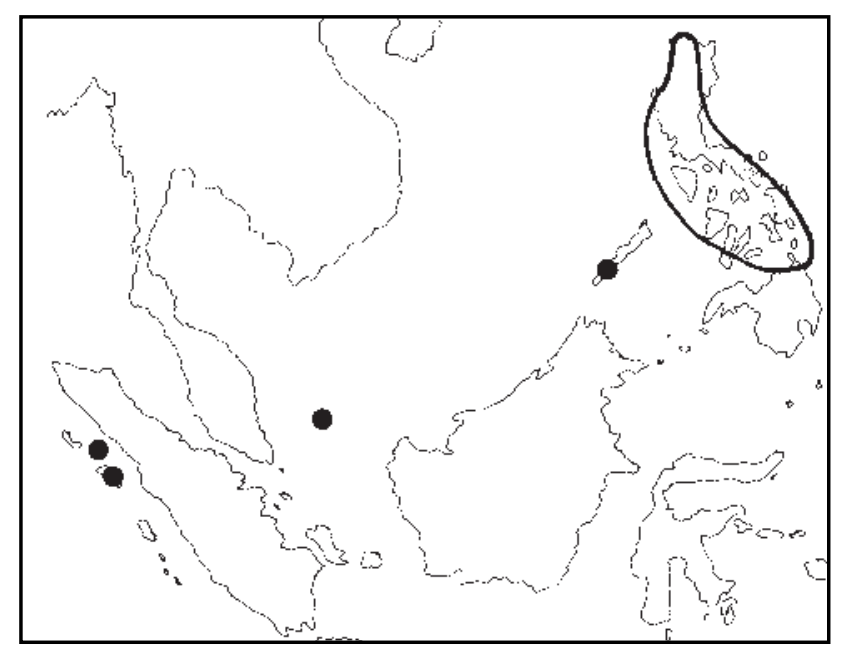

Fig. 86. Xanthophytum ferrugineum (DC) Merrill (Rub.) (Axelius 1990).

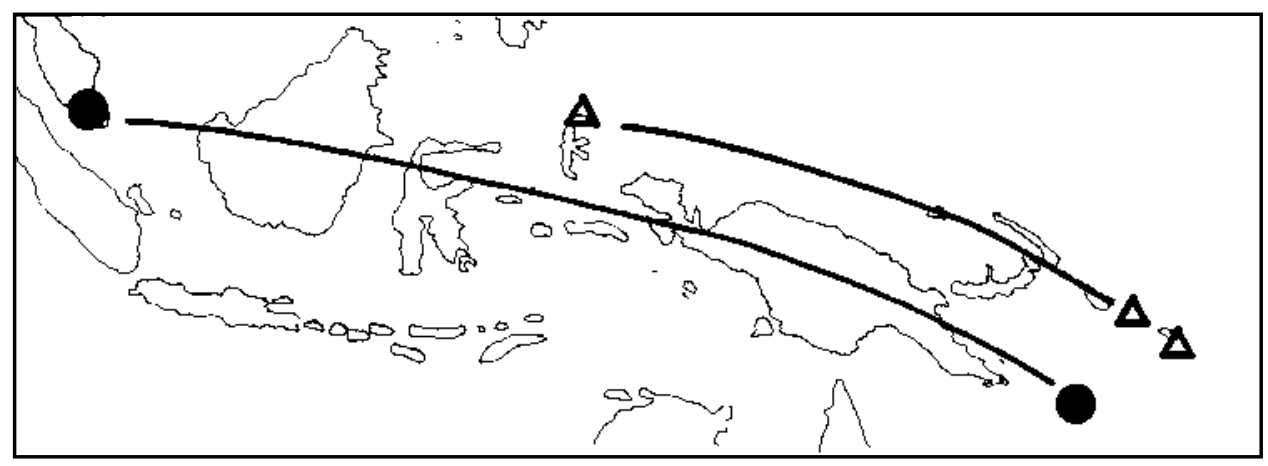

Fig. 87. Podocarpus spathoides de Laub. Peninsular Malaysia and Rossel I. populations have foliage buds up to $3 \mathrm{~mm}$ long, Moluccas and Solomons plants have buds twice as long (de Laubenfels 1988).

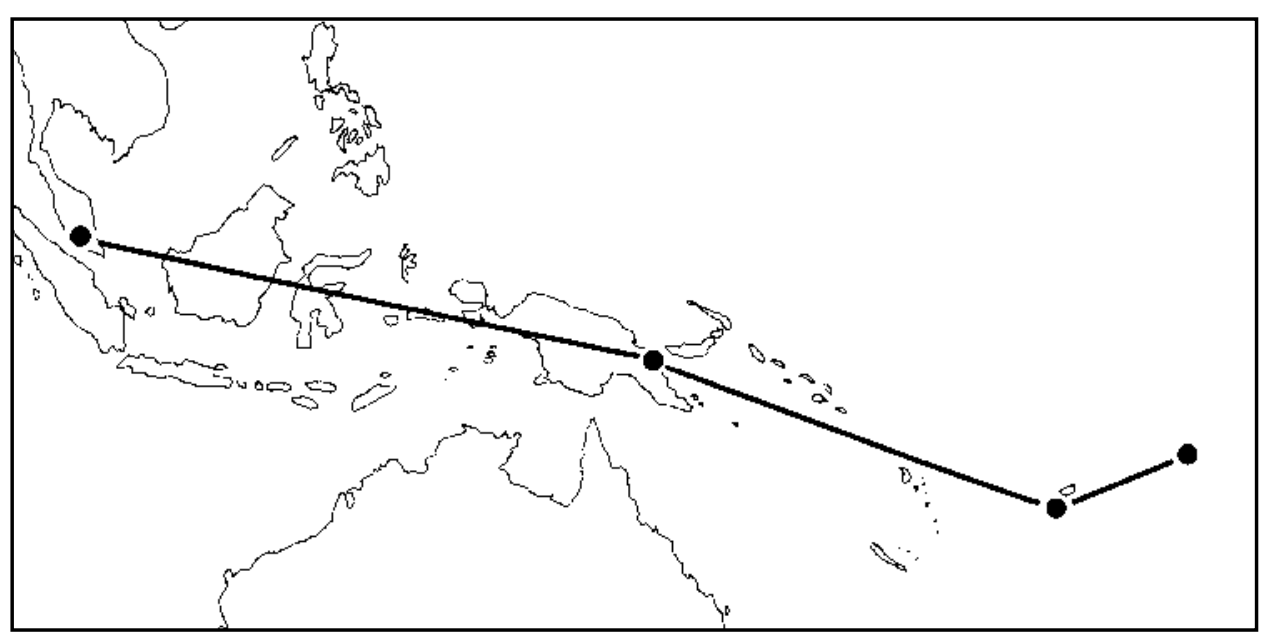

Fig. 88. Ponera Latreille (Hymenoptera: Formicidae) (Taylor 1967). 


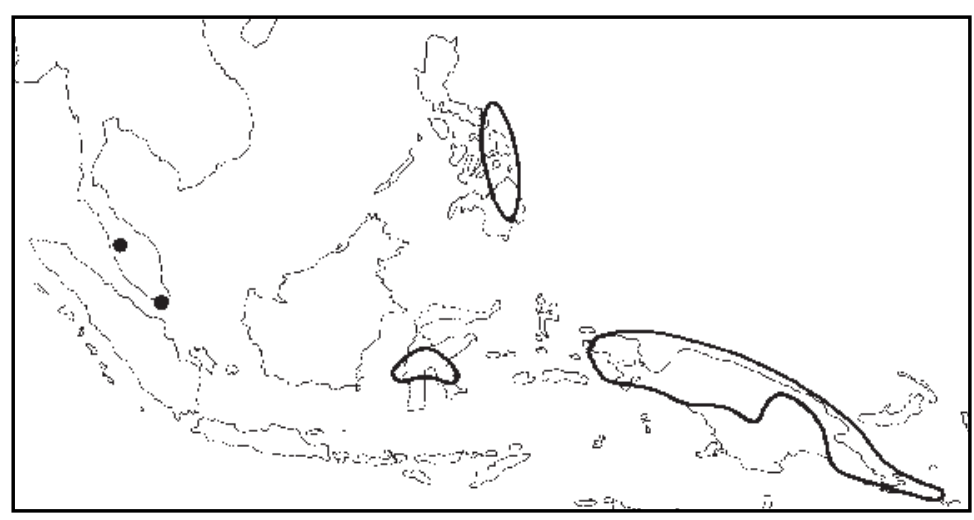

Fig. 89. Parsonsia curvisepala (Apocyn.) (Middleton 1991).

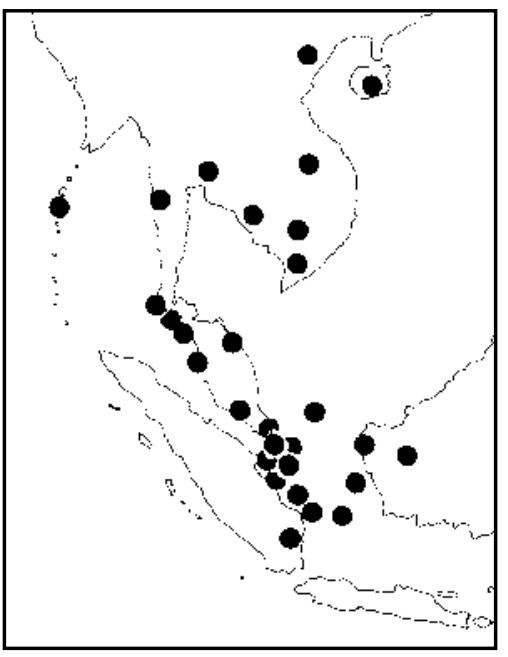

Fig. 90. Ancistrocladus tectorius Merr. (Ancistroclad.) (the only Malesian member of the family) (van Steenis 1948).

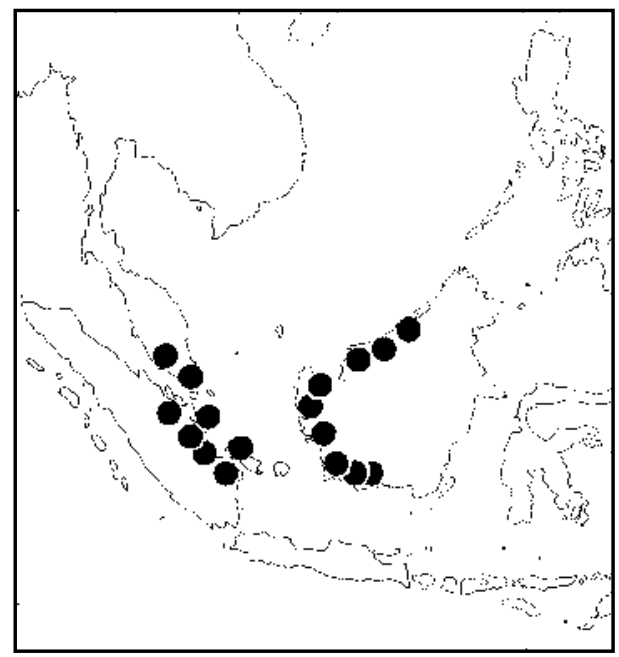

Fig. 91. Gonystylus bancanus (Miq.) Kurz (Thymel.) (Airy Shaw 1953).

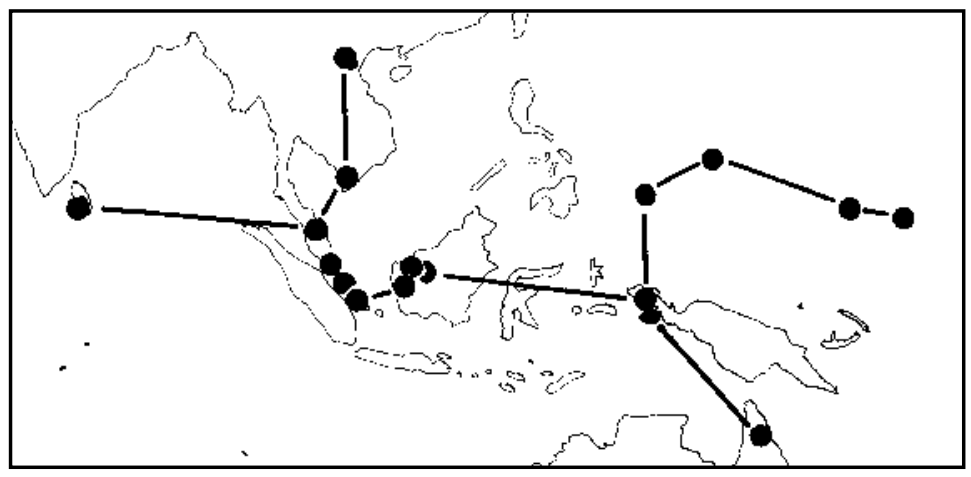

Fig. 92. Lindsaea walkerae Hook. (Dennstaedt.) (Kramer 1971). 
around the Riouw pocket (van Welzen 1994a). Thus plants with mangrove ecology may invade the Riouw pocket, or not. These alternative distributions would seem to have little to do with ecology, and are presumably due to different histories.

\section{W. Sumatra - W. Borneo Mangrove Track}

An example of this pattern is given above in Rhododendron brookeanum. An especially interesting W Borneo species, Podocarpus micropedunculatus de Laub., is found in N. Sarawak, Brunei, and Sabah. It ranges from sea level to $500 \mathrm{~m}$ on humic peaty podzols of raised beaches, in peat-swamp forest, kerangas, and Agathis forest and is a major element in thickets along the margins of clearings (de Laubenfels 1988). It propogates by rhizomes which spread under the forest litter - a remarkable character otherwise unknown among erect conifers. The distribution, habitat and the plagiotropy all suggest a weedy, mangrove relic.

In an example from insects, Holloway and Hall (1998) recorded the Antheraea frithi complex of emperor moths from mangrove in W Sumatra (Tapanuli), Belitung [Billiton] Island (Riouw pocket), the W. Borneo coast and Palawan, following the usual mangrove track. Elsewhere the moths are in hill and montane forest in mainland Asia, Mentawei Islands, Sumatra, Borneo (where the montane species is also at low altitude in heath forest on river terraces), and Sulawesi.

\section{Borneo}

Like many Ericaceae, other plants also surround Borneo without occurring on it (Figs. 93-106). Other examples include Strophioblachia Boerl. (Euphorb.) (Thin et al. 1998) and invertebrates such as the spider genus Fecenia (Levi 1982). The pattern has been attributed to ecological factors (for example, there is no significant dry season in most of Borneo), but this seems unlikely as the taxa concerned show the entire range of ecologies. An example of a mangrove associate avoiding Borneo is Sauropus villosus (Blanco) Merr. (Euphorb.) (open thickets, often near the sea-shore etc.: N Sumatra, Peninsular Malaysia, Philippines) (van Welzen, in press). In fact, biogeography may determine ecology: taxa restricted to, say, drier parts of the Lesser Sunda Islands, Sulawesi and Philippines due to biogeographic/geological reasons may be forced to survive there (or go extinct).

Corner (1961) argued that 'Distribution must have been a geologically slow process. This point of view is repeatedly argued by Croizat (1958) who points to Cretaceous geography as the guide even to modern details of distribution. In Sarawak, where forest is still so abundant, the force of his argument can be appreciated: localization of plants, unable to spread, makes the flora a complicated mosaic ...'

Several terranes in Borneo appear to be of biogeographic significance. Kinabalu is discussed above. Biogeographically, and perhaps geologically, Kinabalu belongs largely with the Philippines mountain systems rather than with the rest of Borneo.

Sarawak and Kutei Mts./Mt. Kemul in Kalimantan are important centres that both interact with Kinabalu but not each other.

The well-documented W. Borneo track: Sarawak-Brunei-Sabah is seen in many Ericaceae, and possibly represents a direct extension of the Riouw Pocket distributions. In another example, Indovethia (Ochn.), cited above in connection with the Riouw Pocket, is possibly closest to Schuurmansiella Hall, a monotypic genus in Sarawak (1st and 4th Div.) (Kanis 1971). In Borneo Soulamea Lam. (Simaroub.) (Nooteboom 1964) has a restricted distribution in the west and north (Fig. 107). Steenisia Backh.f. (Rub.) is only in central, north and west Borneo, and the Natuna Islands, west of Borneo (Bremer 1984). 


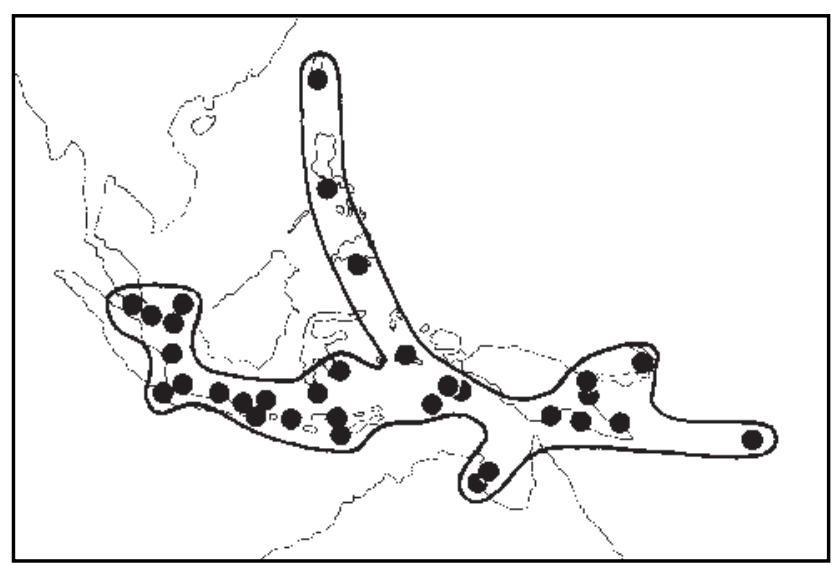

Fig. 93. Rhizophora stylosa Griff. (Rhizophor.) (Ding Hou 1958).

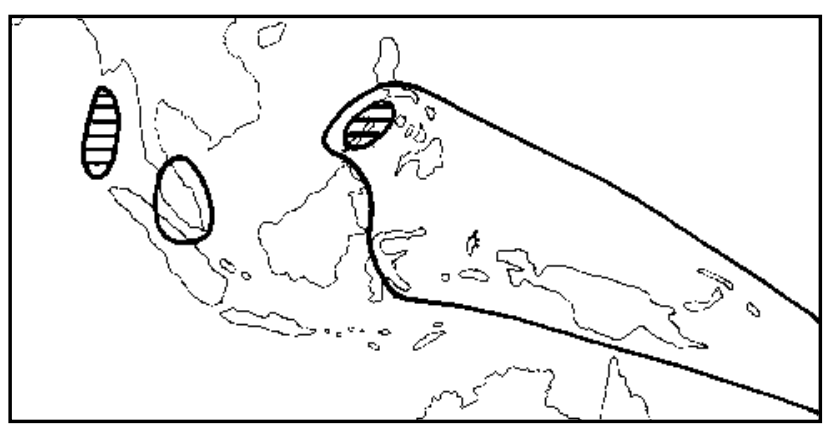

Fig. 94. Codiocarpus Howard (hatched) and Medusanthera Seem. (Stemonuraceae - Sleumer 1971a, Kårehed 2002). Medusanthera is in coastal swamp forest, primary and secondary forest etc. and on limestone and coral, at 0-300 (900) m. It was once found in Western Highlands Prov., PNG, at $1740 \mathrm{~m}$.

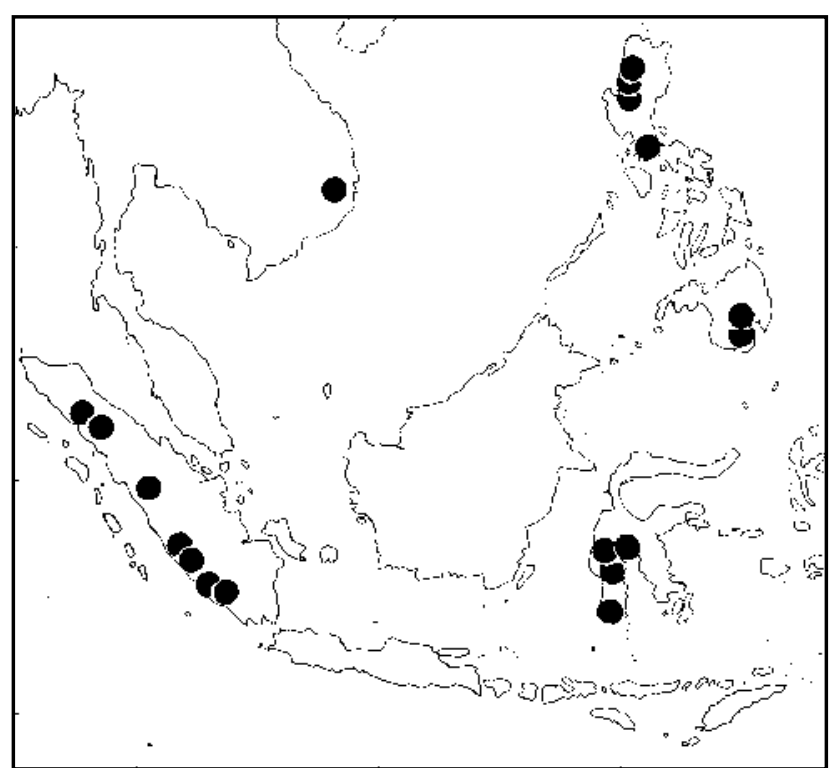

Fig. 95. Taxus sumatrana (Miq.) de Laub. (de Laubenfels 1988) 


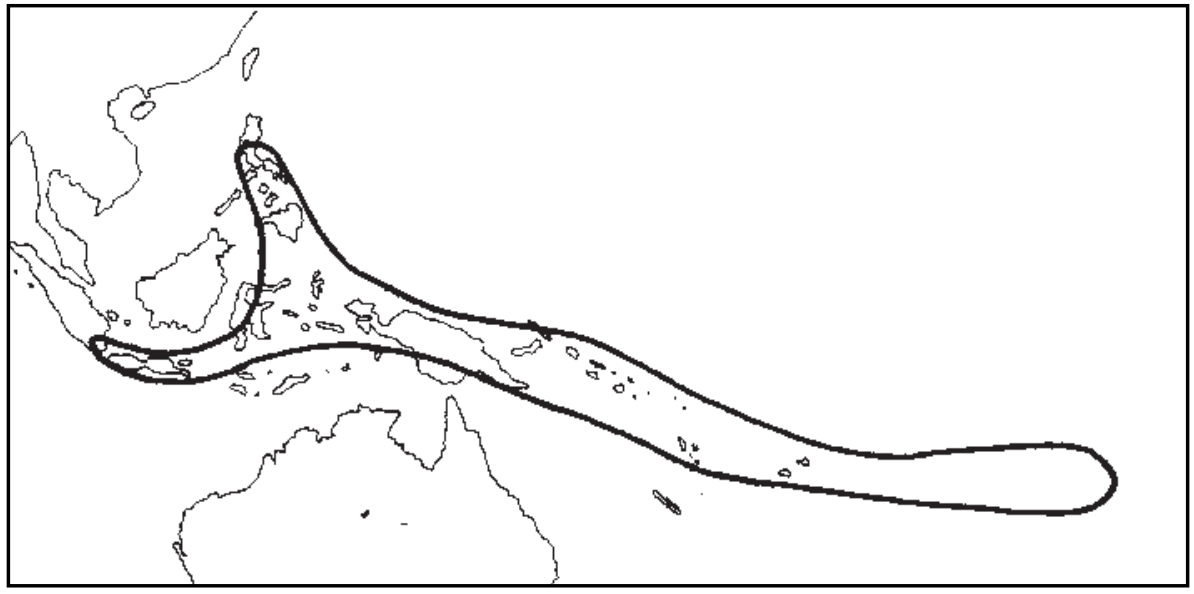

Fig. 96. Parasponia Miq. (Ulm.) (Soepadmo 1977).

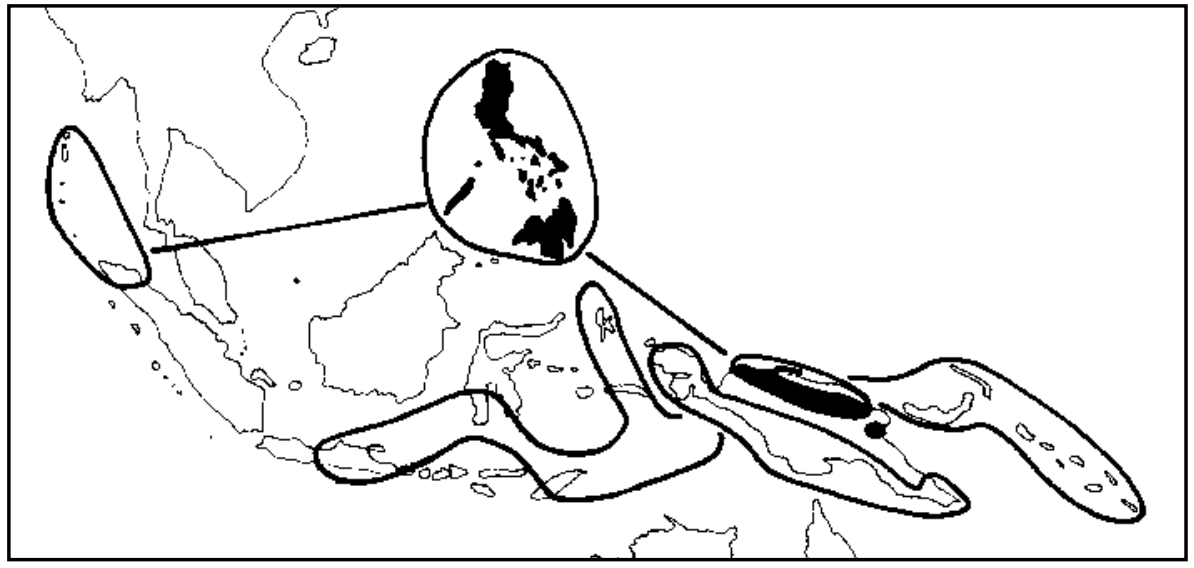

Fig. 97. Lepidopetalum Blume (Sapind.) (van Welzen 1993).

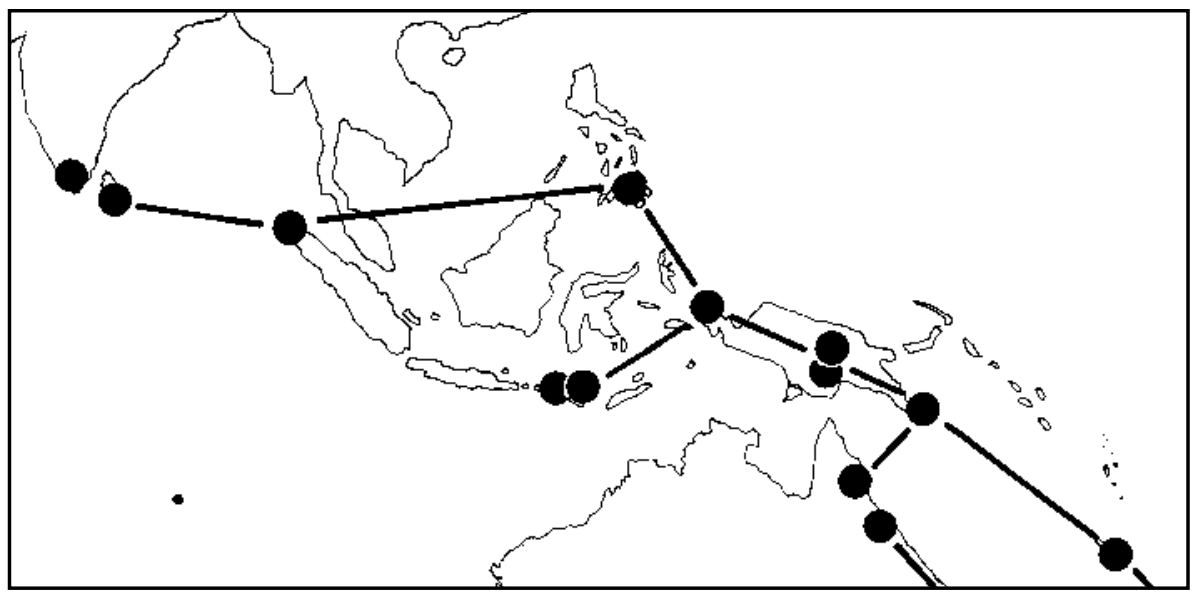

Fig. 98. Orthorrhynchium elegans (Hook. f. and Wils.) Reichdt. (Musci) (Tan 1998). 


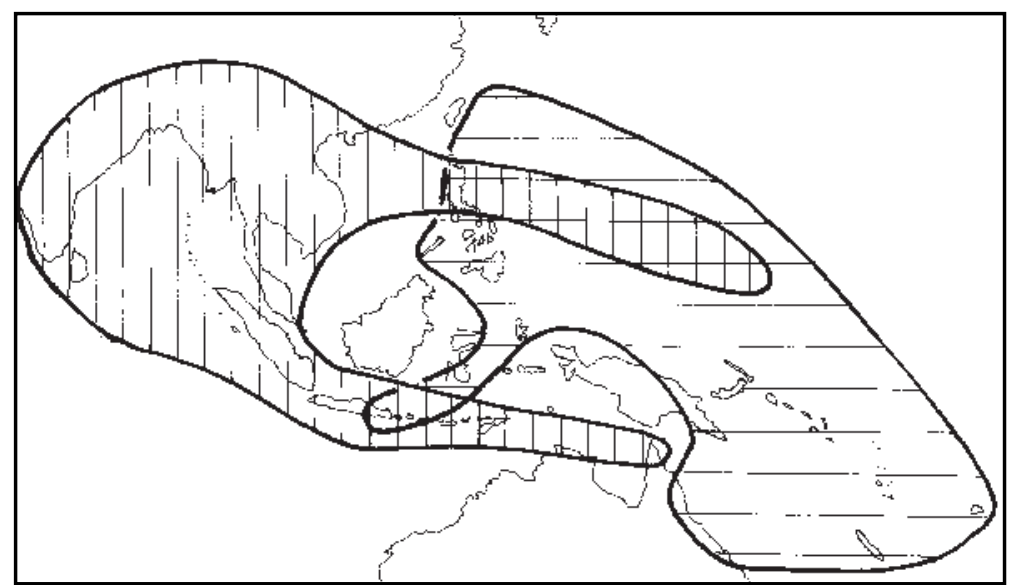

Fig. 99. Balanophora fungosa J.R. \& G. Forst. ssp. fungosa (east), and ssp. indica (Arn.) Hansen (west) (Balanophor.) (Hansen 1974).

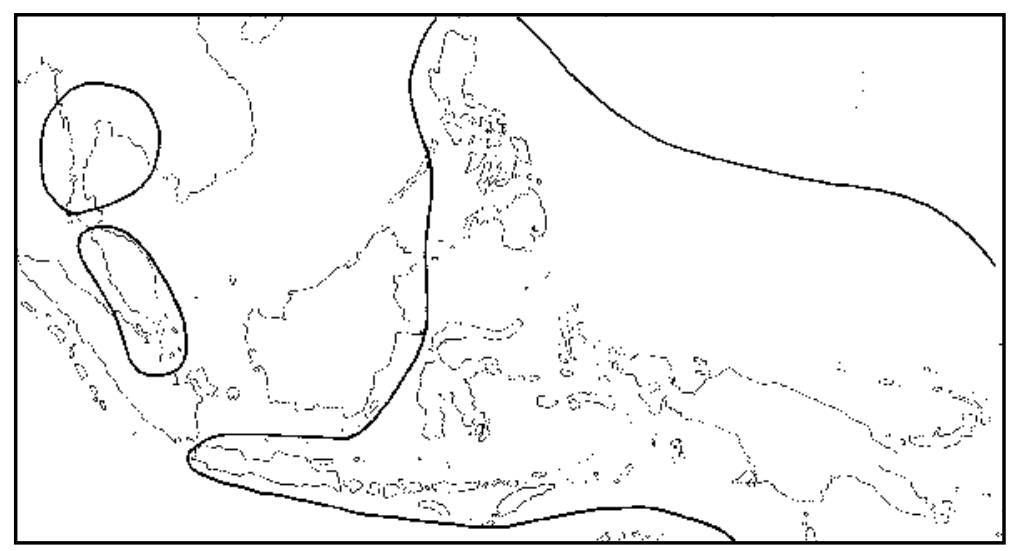

Fig. 100. Tribe Bannisterieae (Malpighiaceae) in Malesia: Brachylophon Oliv. in the west (also in East Africa); Rhyssopteris Blume ex A.Juss. in the east (to Queensland and New Caledonia) (Jacobs 1954).

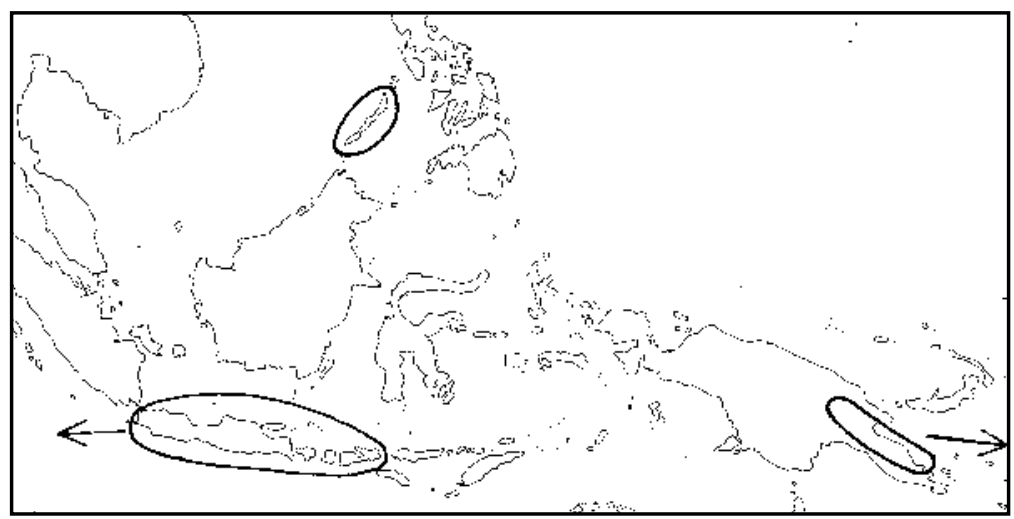

Fig. 101. Protium Burm.f. (Burser.) in Malesia (also in Madagascar, Mascarenes, SE Asia, and America (Leenhouts et al. 1956). 


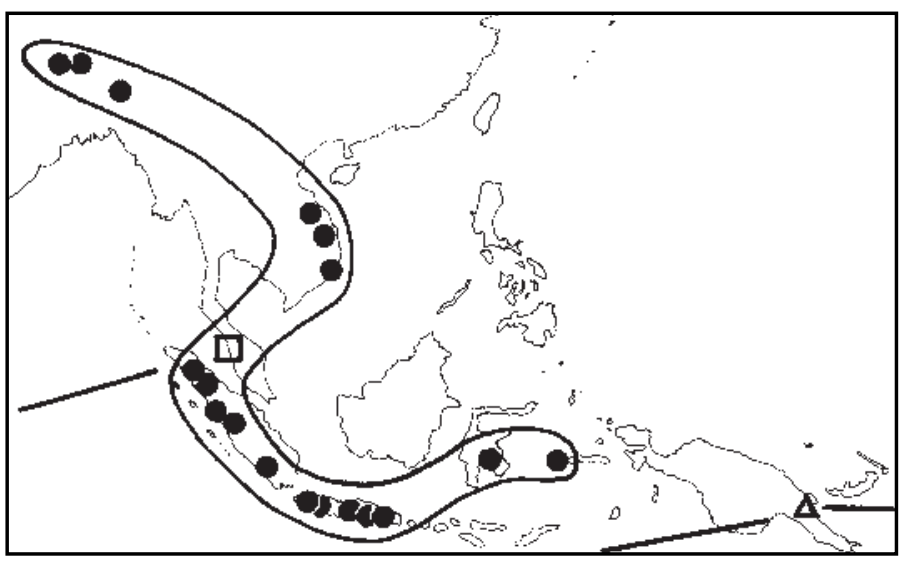

Fig. 102. Rhopalocnemis Jungh. (Himalaya - Moluccas), Ditepalanthus Fagerl. of Madagascar; Exorhopala Steen. (square); and Langsdorffia Mart, (also in Madagascar and Central and South America) (Balanophoraceae) (Hansen 1974).

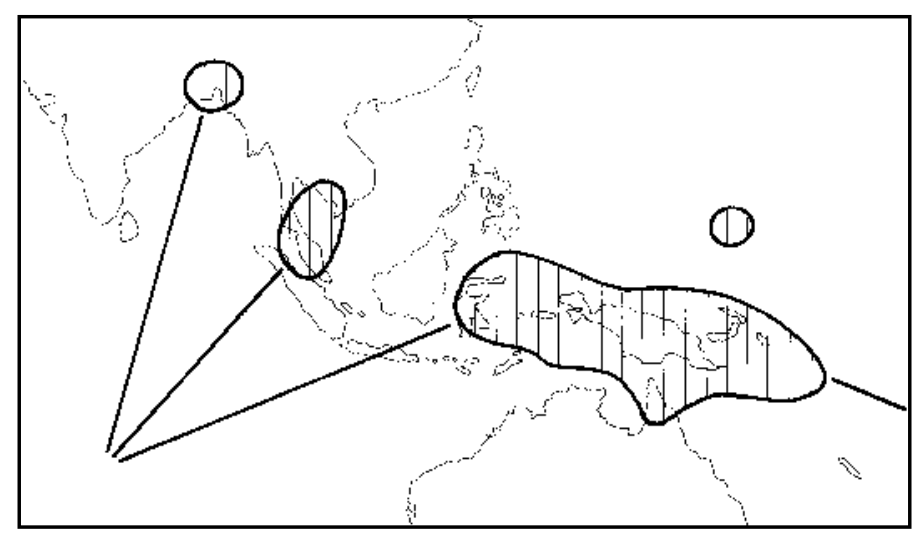

Fig. 103. Maniltoa Scheff. (Legum.) (de Vogel 1975c).

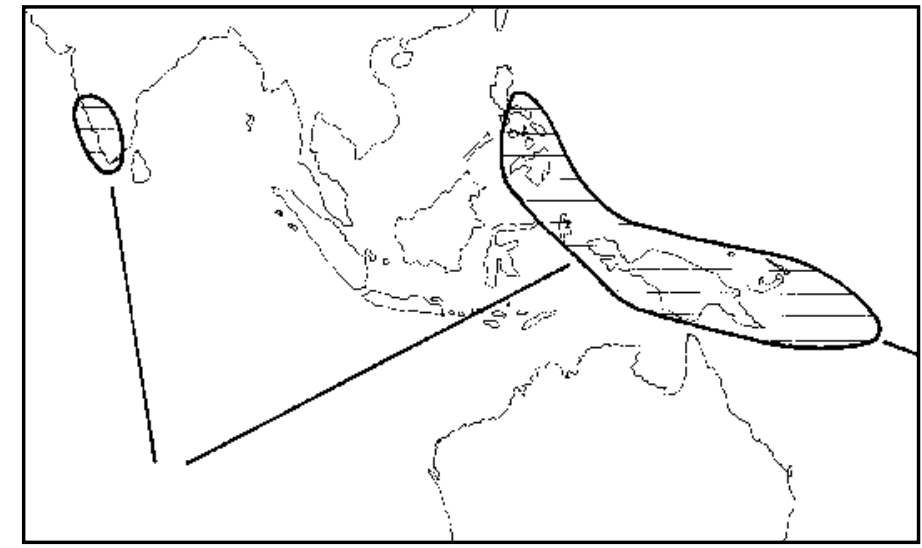

Fig. 104. Kingiodendron Harms (Legum.) (de Vogel 1975b). 


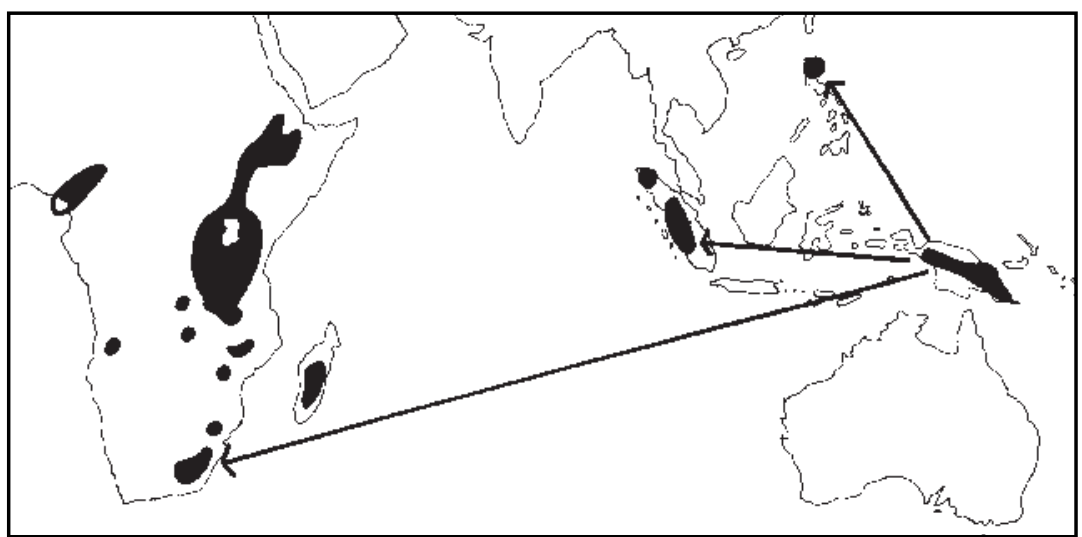

Fig. 105. Hypericum sect. Humifusoideum (Robson 1981).

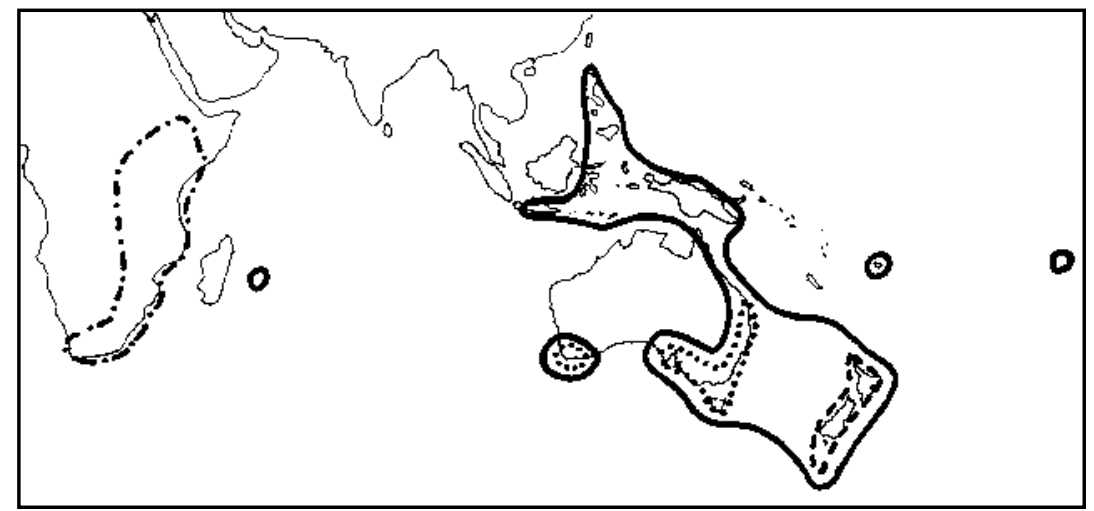

Fig. 106. Ehrharta Thunb.: s.s. Africa (broken dotted line); s.l. including Microlaena R.Br. (continuous line). Tetrarrhena R.Br. (dotted line), Petriella Zotov (broken line). (Gram.) (Willemse 1982).

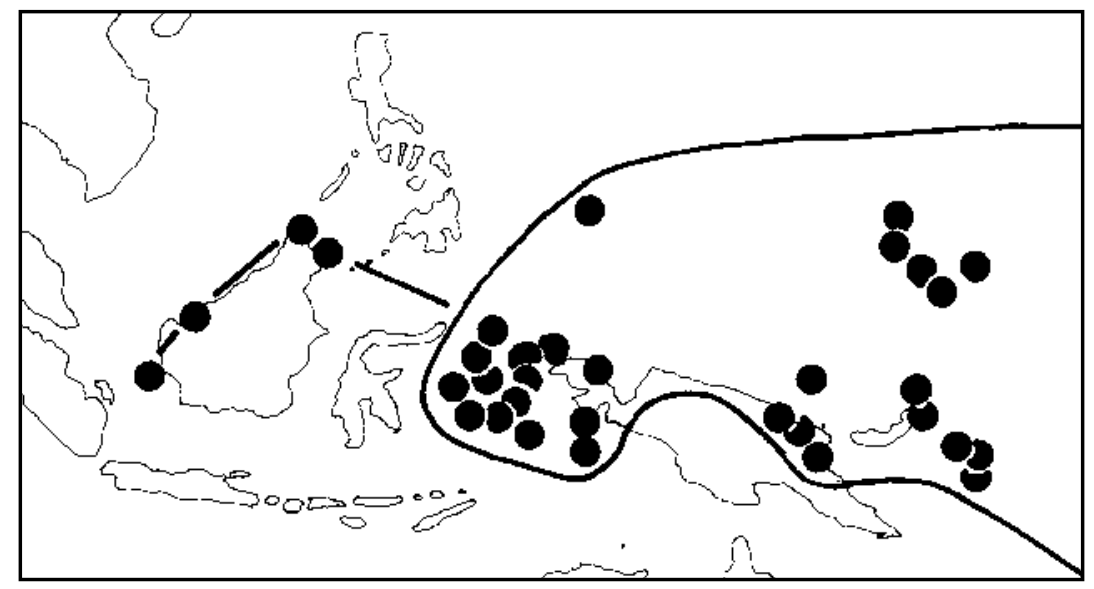

Fig. 107. Soulamea Lam. (Simaroub.) in Malesia (Nooteboom 1964). 
The eastern Borneo track: Kinabalu-Kemul is shown in Ericaceae and Fagaceae endemic to Kinabalu/Kutei (Castanopsis endertii Soepadmo) and Kinabalu/Crocker Range/Kemul (C. densinervia Soepadmo) (Soepadmo 1972). The Mangkalihat Mountains give their name to the Mangkalihat terrane which extends from CE Borneo inland to about Mt. Kemul (Metcalfe 1999, 2001).

Taxa restricted to the NE of Borneo include Podocarpus rumphii Bl. (Fig. 108), Serianthes Benth. (Leg.) (Fig. 109), Lophopyxis (Lophopyxid.) (Fig. 110) and Hugonia L. (Lin.) (Fig. 111). In the central-eastern part of Borneo are Deplanchea glabra (Steen.) Steen. (Fig. 112) and Podocarpus sect. Gracilis de Laub. (Fig. 113).

East Borneo and West Sulawesi appear to be underlain by accreted arc and ophiolitic material as well as continental crust and this material was accreted during the Cretaceous (Hall 1998).

Hall (2001) wrote that 'Some of the biogeographic patterns in SE Asia at present are difficult to relate simply to geology, for example, the distance between Borneo and Sulawesi (Wallace's line and equivalents) should have been as easy to cross as the barriers between Australia and Sulawesi.' Actually the records (not the Wallacean theory) show that it was. For example, 25B: Rhododendron cuneifolium Stapf, Trochocarpa 3, and the pairs Rhododendron 123 and 124, Diplycosia 16 and 17, and Vaccinium 18 and 19 all show this sector of Wallace's line (Makassar Strait) not as a boundary but as a centre of endemism. The real boundary is between $\mathrm{E}$ and $\mathrm{W}$ Borneo. This pattern is also recorded in vertebrates: the freshwater fishes of the region 'are not distributed according to existing land. Those of Sumatra and western Borneo are more alike than those of the western and eastern sides of Borneo' (Darlington 1957).

In SE Borneo, the region of the Meratus suture, Rhododendron 131B (on sandstone) and Vaccinium 25 (collected once, in 1836) are endemic to the Meratus Mts. These, with the nearby Pulo Laut, include the only ophiolite complexes in Kalimantan and here the process of obduction (the opposite of subduction) has produced large upthrust slabs of oceanic crust. The Meratus Mountains are floristically distinct from other regions and are a site of plant richness and endemism. Local endemics include Nepenthes boschiana Korth. of limestone hills (Cheek and Jebb 2001) and the region is especially rich in orchids (Mackinnon et. al. 1996, citing E. de Vogel, pers. comm.), such as Porphyrodesme Schltr., only known from there and New Guinea. The Meratus Mts. appear to be one of the places where Borneo is 'entered' by tracks from the south and east, like Mt. Kemul further north. The Meratus Mts. represent a suture between the SW Borneo and Paternoster terranes dated as Late Cretaceous (Metcalfe 1998).

Euonymus javanicus B1. (Celastr.) (Fig. 114), Lumnitzera racemosa (Combret.) (Fig. 115) and Agrostistachys capitata Dalzell (Euphorb.) (Sevilla and van Welzen 2001) are restricted in Borneo to the southeast (Meratus suture region), and Phaleria capitata (Thymel.) (Fig. 116) is largely restricted to the southeast. Calophyllum lanigerum Miq. (two varieties) and $C$. dasypodum Miq. show an interesting set of parallel arcs converging on SE Borneo (Fig. 117).

The large area of mélange in the centre of Borneo is less well-understood. This is a zone of broken rocks, often including fragments of ophiolite, but its width and extended geological age (late Mesozoic to older Tertiary) are 'difficult to explain in terms of simple plate tectonics' (Mackinnon et al. 1996). 


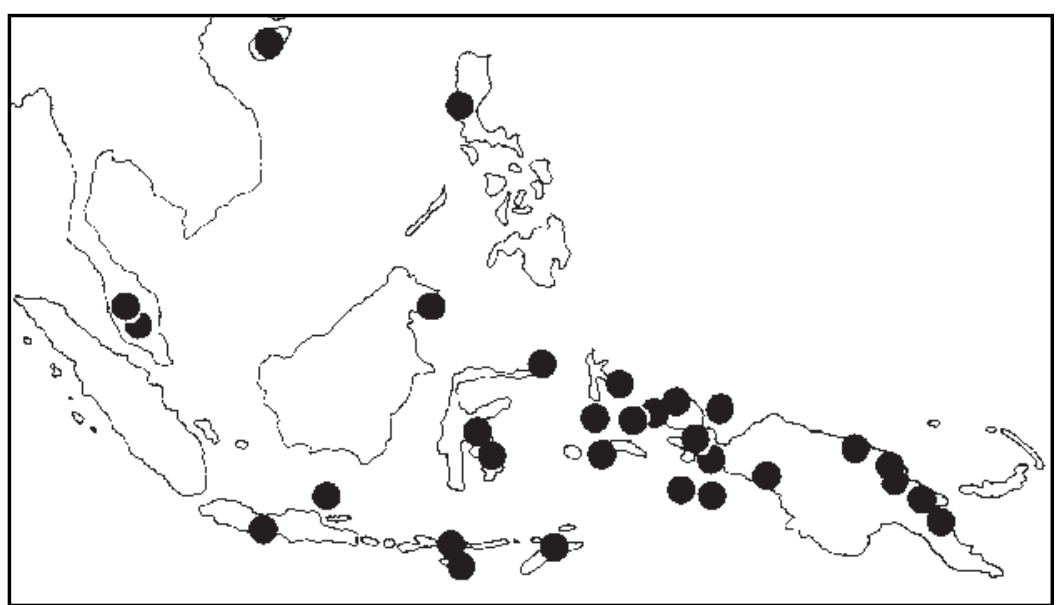

Fig. 108. Podocarpus rumphii Bl. (de Laubenfels 1988).

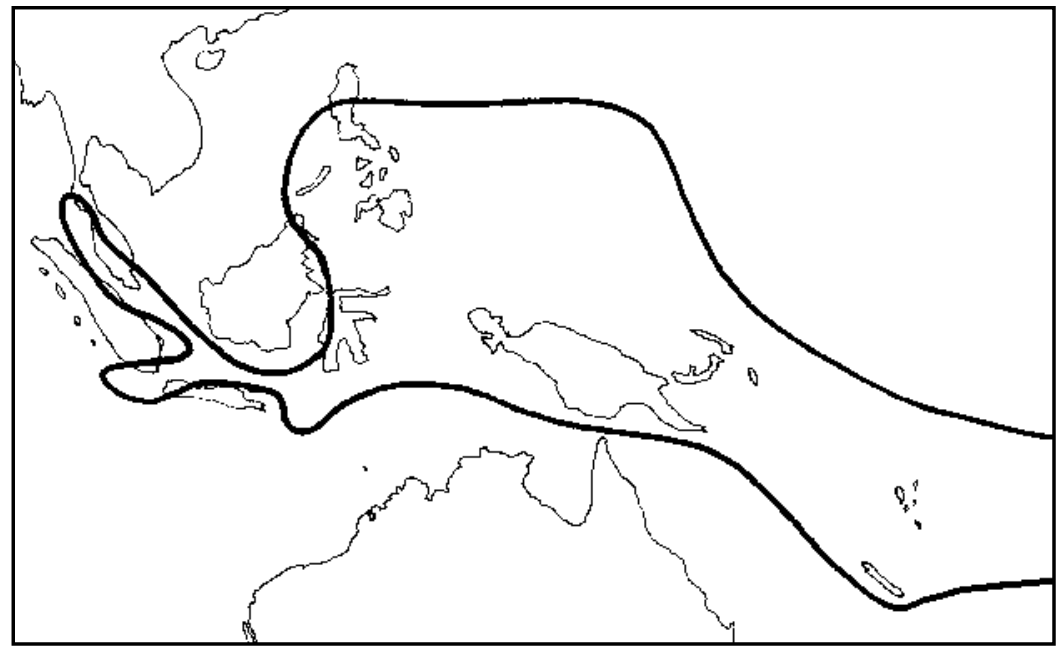

Fig. 109. Serianthes Benth. (Legum.) (van Balgooy and Nielson 1993).

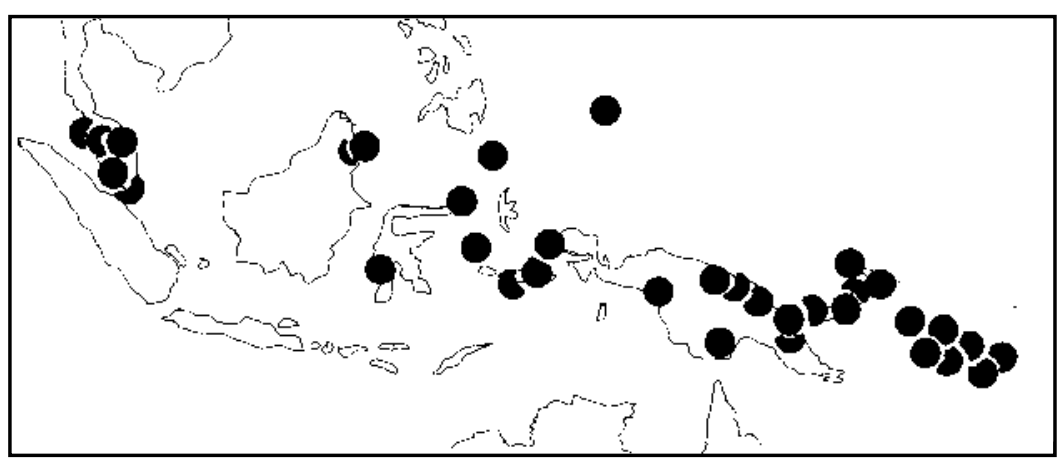

Fig. 110. Lophopyxis Hook. f. (Lophopyxid.) (de Vogel 1975). 


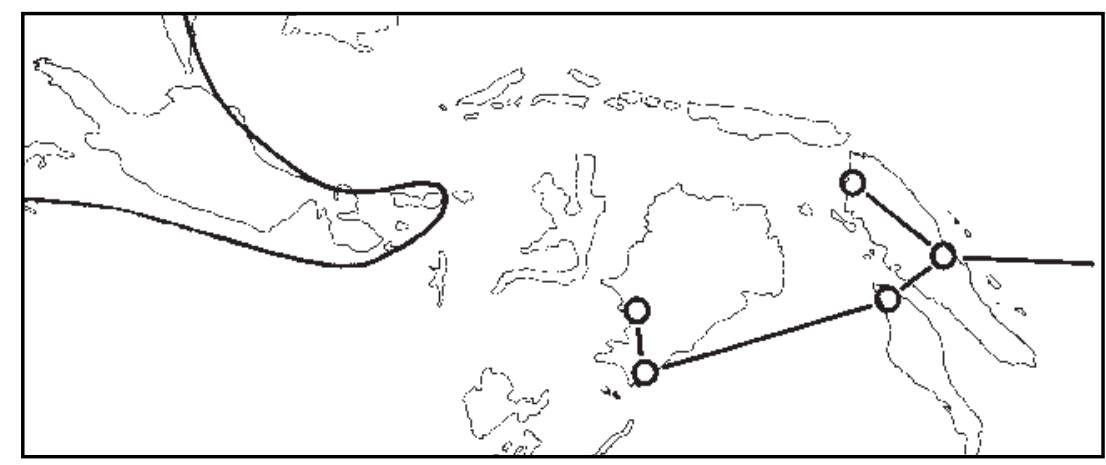

Fig. 111. Hugonia L. (Lin.) in Malesia (two species) (van Hooren and Nooteboom 1988). Other species are in Sri Lanka, India, Madagascar and Africa.

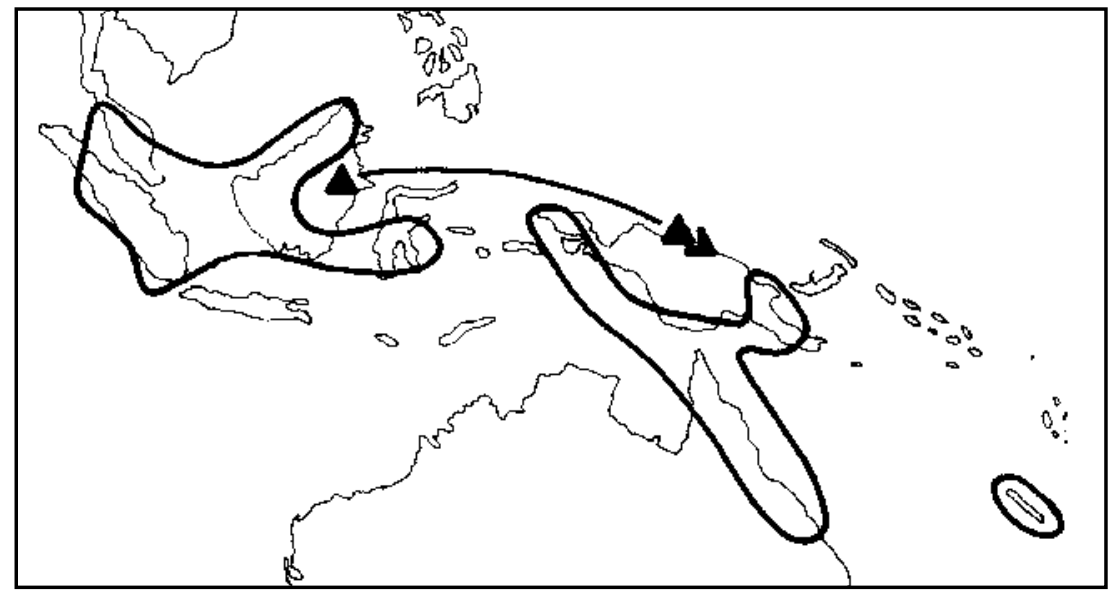

Fig. 112. Deplanchea Vieill. (Bignon.) (Avé 1984).

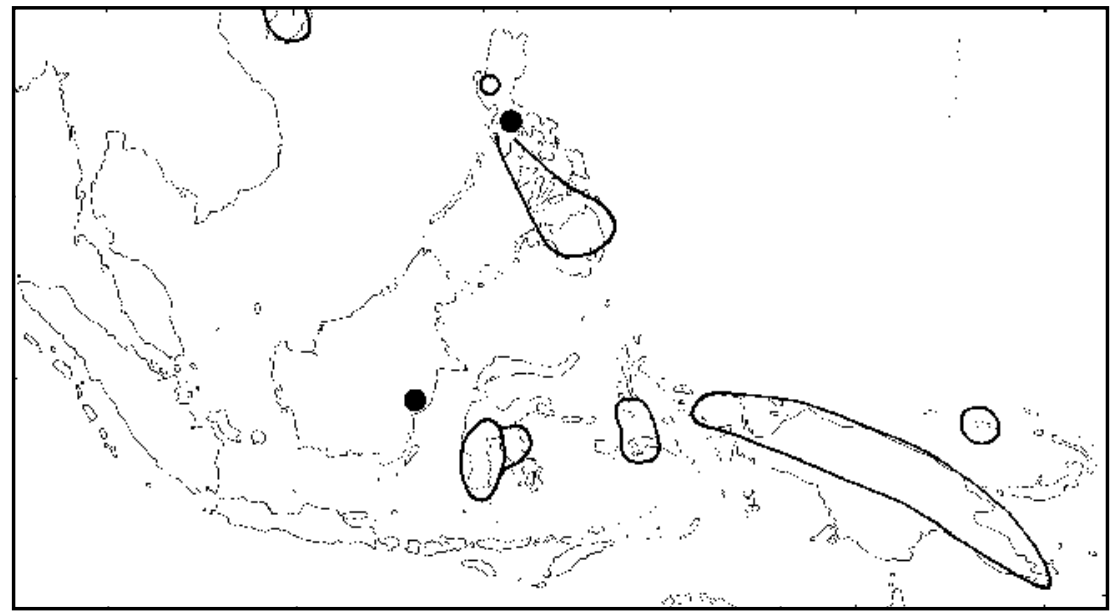

Fig. 113. Podocarpus sect. Gracilis de Laub. (Podocarp.) (de Laubenfels 1988). 


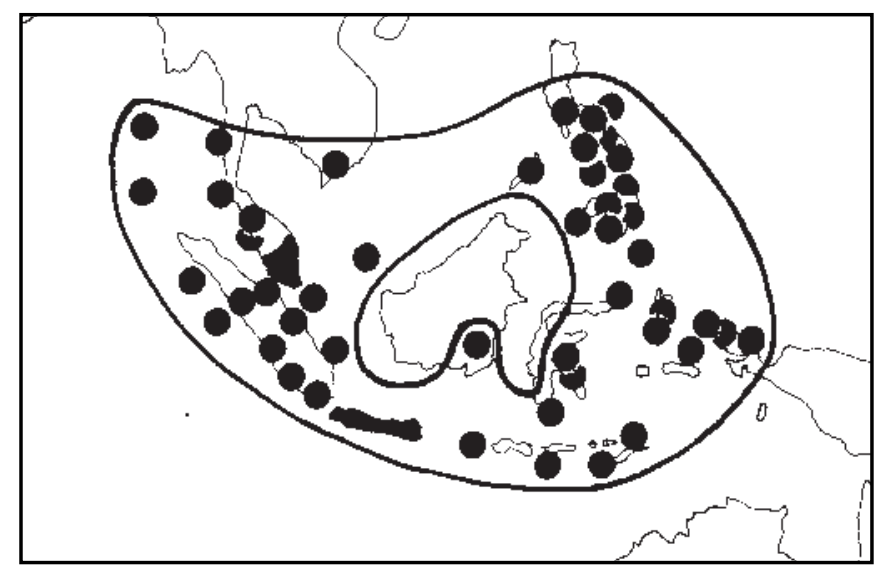

Fig. 114. Euonymus javanicus Bl. (Celastr.) (Ding Hou 1964).

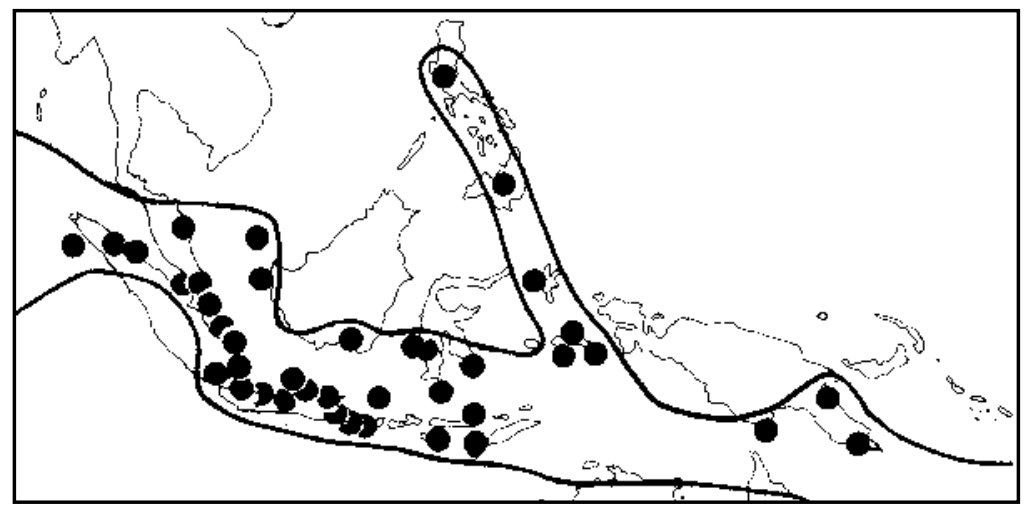

Fig. 115. Lumnitzera racemosa (Combret.) (Exell 1954).

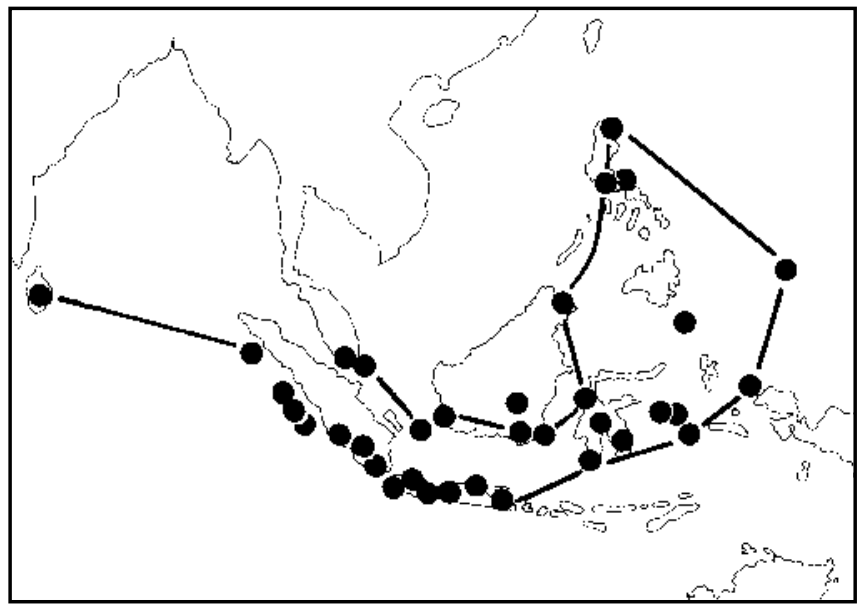

Fig. 116. Phaleria capitata Jack (Thymel.) (Ding Hou 1960). 


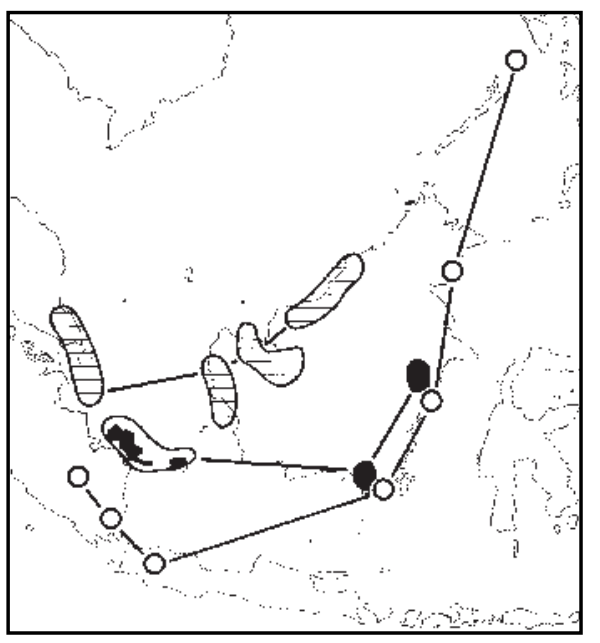

Fig. 117. Calophyllum lanigerum Miq. var. austrocoriaceum (T.C.Whitmore) P.F.Stevens (hatched); C. lanigerum var. lanigerum (solid black); C. dasypodum Miq. (open circles) (Guttiferae) (Stevens 1980).

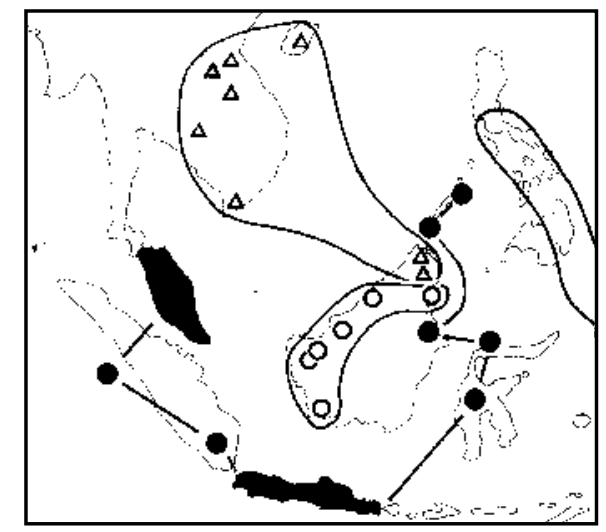

Fig. 118. Myxoporum Bl. (Olea.) (Kiew 1984) in W. Malesia: three subspecies of M. nervosum, all in Borneo and M. ovatum (Philippines).

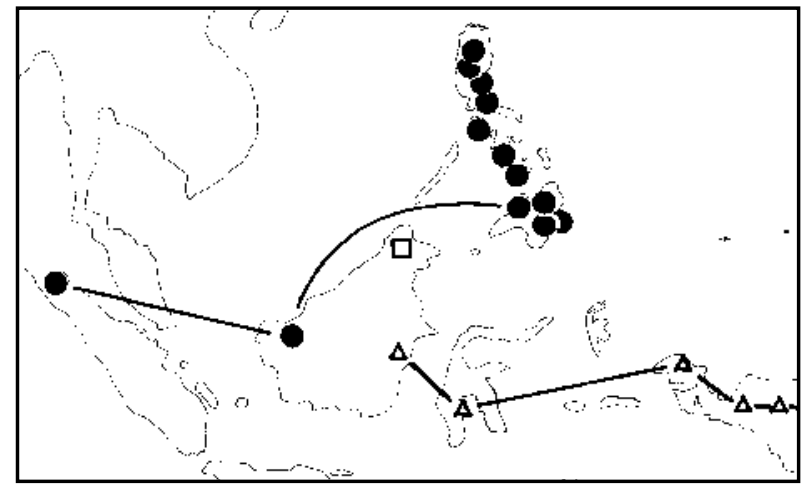

Fig. 119. Three related species in Dacrycarpus (Podocarp.) (de Laubenfels 1988): D. cumingii (dots), D. steupii Wasscher de Laub. (triangles), D. kinabaluensis (Wasscher) de Laub. (square). 


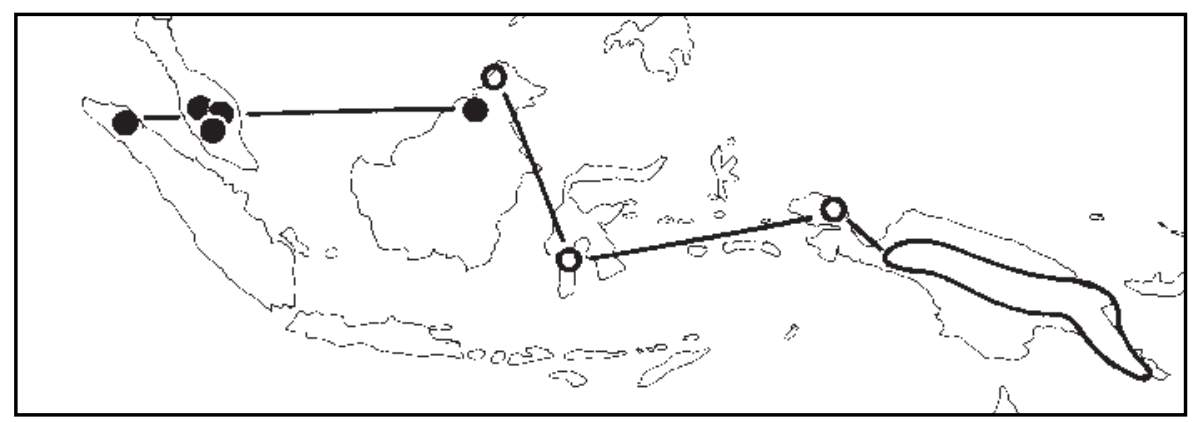

Fig. 120. Oreobolus R.Br. (Cyper.) in Malesia (Seberg 1988). Two species are mapped, the third is also in the New Guinea mountains.

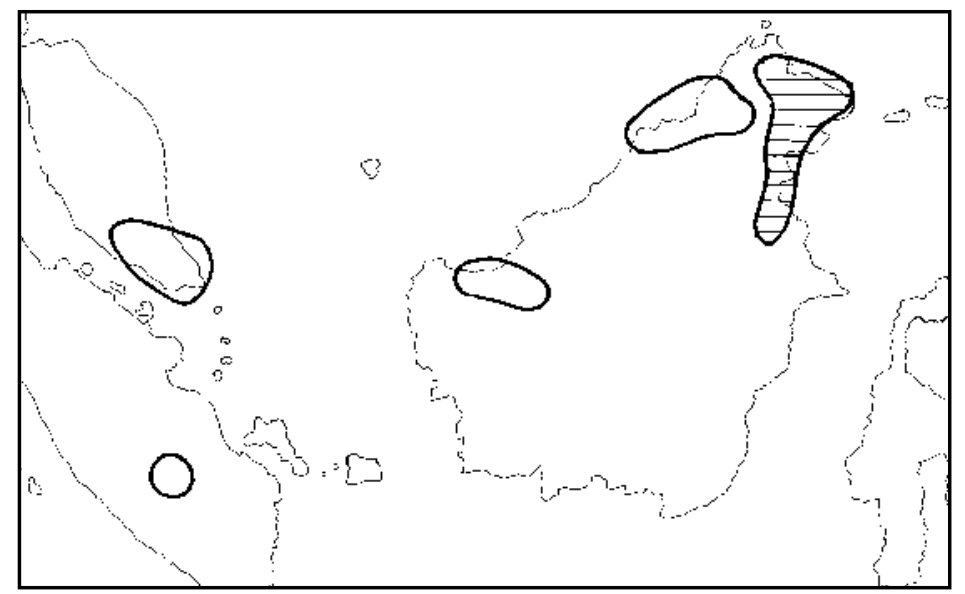

Fig. 121. Neoscortechinia sumatrensis (west) and N. angustifolia (east) (Euphorb.). The genus also includes two other W Malesian species and one in New Guinea (van Welzen 1994a). Note the distribution of N. sumatrensis centred around the Riouw pocket.

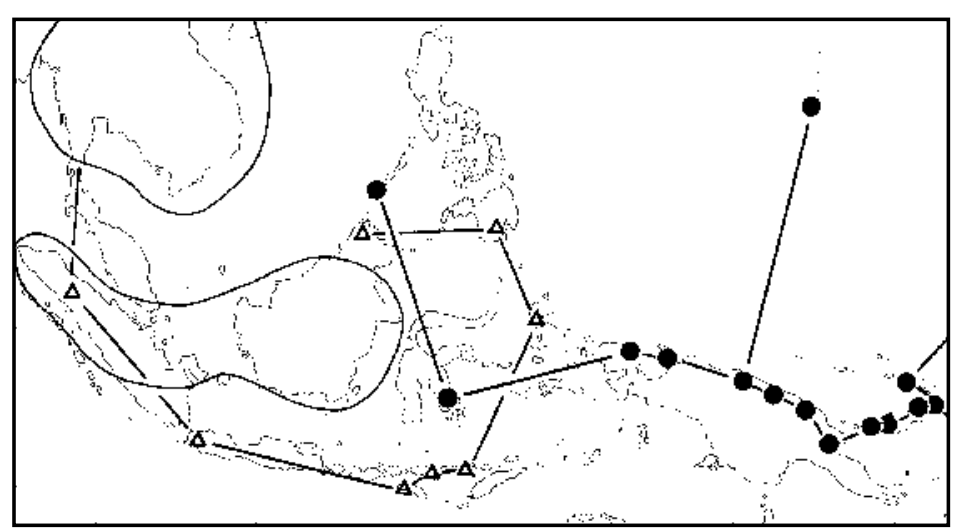

Fig. 122. Apodytes Am. (Icacinaceae s.s.) (SE Asia and triangles), Cantleya Ridl. (Sumatra-Borneo) and Merrilliodendron (dots) (Stemonuraceae) (Sleumer 1971a, Kårehed 2001). 
The deconstruction of Borneo into western, northern and eastern sectors is illustrated by differentiation in Myxoporum (Olea.) (Fig. 118), Dacrycarpus (Podocarp.) (Fig. 119), Oreobolus (Cyper.) (Fig. 120), Neoscortechinia Hook.f. ex Pax (Euphorb.) (Fig. 121) and Icacinaceae/Stemonuraceae (Fig. 122). In Calophyllum, good examples are seen in C. alboramulum P.F.Stevens (Peninsular Malaysia, central West Borneo) and C. blancoi Planchon \& Triana (N and CE Borneo, Philippines) (Stevens 1980, Map 3).

Why is Rhododendron so much more diverse in New Guinea (especially Irian Jaya) than in Borneo when it is not even a Pacific group? (Note that the number of Rhododendron species in Borneo in Sleumer's (1966 Fig. 1) map, i.e. 28, does not agree with the number of species in the text - 37). Borneo does not have many really high mountains, but as indicated, the altitudinal centre of diversity for Rhododendron is only 1500-2000 m. It seems likely that Rhododendron is much less diverse in Borneo than in New Guinea for the same reasons that many groups largely or totally avoid Borneo - not because of means of dispersal but because of different ancestral massings in the different groups. Alternative nodes and tracks, such as Borneo-wide endemism vs. tracks peripheral to Borneo, are held by different organisms not because of different means of dispersal or ecology but because the different groups evolved there, on the different sectors.

\section{Philippines}

The Philippines (except for Palawan) represent an amalgamation of island arc terranes and juxtaposition of these against fragments of continental (Eurasian) margin (Pubellier et al. 1996). Belts of ultramafics are shown in Fig. 123 (from Brooks 1987), indicating aspects of the arc structure. In the Eocene parts of the archipelago lay south-east of their present position (Hartley 2001). Hall's (1998, 2000) reconstruction of the region for 30 Ma shows the east Philippines, northern Moluccas and north New Guinea terranes (including New Britain) forming a relatively continuous arc, running parallel with and 1-2000 km north of New Guinea, before moving south and west and docking. This would go some way to explaining the close connections among these regions and also the great difference between the northern and southern Moluccas. Excellent animations illustrating this model are available at http://www.gl.rhul.ac.uk/seasia/movies.

Nevling (1961) wrote that the Philippines - New Guinea disjunction seen in Enkleia paniculata (Merr.) Hallier f. (Thymel.) (Luzon - Vogelkop) is 'puzzling indeed'. However, as shown above in the Ericaceae, there are many direct Philippines - New Guinea ties. These are seen in groups such as the bird Mearnsia (Philippines and New Guinea only) and the plant Mearnsia Merr. (Myrt.) (Philippines, New Guinea, New Caledonia, New Zealand). 57 ferns are known only from the Philippines and New Guinea (Copeland 1950). Bonds between species of Mindanao and East New Guinea are seen in Legnephora Miers (Menisperm.) (Forman 1986), and Philippines Manus/New Ireland connections in particular are well-documented, for example in the ferns Culcita straminea (Labill.) Maxon (Holttum 1963), Coryphopteris squamipes (Copel.) Holttum (Holttum 1981), Ctenitis pallens (Brackenr.) M.G. Price, and Tectaria tabonensis M.G. Price/T. subcordata Holttum (Holttum 1991). Sets of parallel arcs involving the Philippines, the Moluccas and PNG are observed in a group of Casearia spp. (Flacourt.) (Sleumer 1954) (Fig. 124). Related patterns include those of the Makota generic complex (Hemiptera) (Soulier-Perkins 2000) (Fig. 125), the Orisema uchancoi species group (Philippines - PNG) (Hymenoptera) (Heraty 1995), and a Mindanao-Fergusson I. (Milne Bay) disjunction is seen in Licania Aubl. (Chrysobalan.) (Prance 1989). 
Luzon - Sulawesi (cf. Pseudovireya II, Albovireya) is one of the few 'longitudinal' tracks in Malesia. Van Steenis (1978a: Fig. 18) illustrated it with Biophytum microphyllum Veldk. and wrote that this 'rather peculiar range pattern ... has received too little attention'. George (1987) pointed out that it is now known to occur in plants, amphibians, birds, and mammals. A similar track occurs in Euphorbiaceae such as Doryxylon Zoll. (van Welzen 1999) and Shirakiopsis sanchezii (Merr.) Esser (Esser 1999), and in Semecarpus longifolius Bl. (Anacard.) (the latter with additional records from Java, the Moluccas and Taiwan) (Ding Hou 1978).

\section{Sulawesi}

In dispersal biogeography Sulawesi is merely a stepping stone or transition zone for plants 'invading' eastwards or westwards, but many authors (e.g. Stevens, 1985, on Rhododendron) have been struck by the unexpectedly high diversity there. Likewise, of the 380 bird species in Sulawesi, 'no less than 96 of these are endemic to the region, an incredible 25\% of the avifauna' (Holmes and Phillips 1996). Plants of the Latimodjong Range are central in many Ericaceae distributions and are closely related to plants of the New Guinea orogen.

\section{New Guinea}

Within New Guinea, Stevens (1981) noted that the geographic concentrations of diversity in several groups, such as $R$. ser. Linnaeoidea and $R$. subsect. Pseudovireya are in Irian Jaya. This is also true for Vaccinium sect. Oarianthe, V. sect. Neojunghuhnia, and Rhododendron as a whole - the vireya.net website lists 161 Rhododendron species in New Guinea, with 100 in Irian Jaya, but only 81 in Papua New Guinea (cf. 47 in Borneo, 28 in Sulawesi, 25 in Sumatra, 19 in the Philippines).

The western bias in New Guinea is typical of 'Asian' groups, whereas 'Australian' groups such as birds-of-paradise (Paradisaeidae) are more diverse in the eastern half of the island (PNG). PNG groups like Vaccinium sect. Pachyanthum and Agapetes subgen. Paphia mean that Vaccinioideae are almost as rich in PNG (134 spp.) as in Irian Jaya (143 spp.). In Vaccinium PNG has 134/143 (94\%) of the number of species in Iran Jaya, compared with Rhododendron in which PNG has only 81/100 (81\%) of the number of species in Irian Jaya. This is probably the result of Vaccinium being a fundamentally Pacific group, whereas Rhododendron is an Indian Ocean group, and thus stronger on the western side of the island.

The Irian Jaya biota is also more diverse for birds in general (e.g. 32 mainland bird endemics vs. 15 on mainland PNG).

West and east New Guinea have interacted in complex ways. The folded and faulted mountain ranges of the spine of New Guinea form the New Guinea orogen (Fig. 7, 8). This mountainous belt was formerly regarded as the result of a simple continentisland arc collision, but Pigram and Davies (1987) gave a radical reinterpretation. They described the orogen as consisting of a southern part, the former northern margin of the Australian craton, and a northern part made up of at least 32 tectonostratigraphic terranes, fault-bounded geological provinces with independent histories. The New Guinea terranes, including intrusive and metamorphic rocks, formed and sometimes amalgamated with others some distance from their present position and subsequently accreted to the craton margin. (In ordinary English the craton grows by accretion; in geological English it is the terranes which accrete or, more usually, 'are accreted'). Accretion history in the Vogelkop involves mainly continental terranes. The central Kemum terrane was detached from Gondwana by the early Cretaceous and then had a history of movement independent of the Australian craton until the Miocene. In central New Guinea, the Sepik and Rouffaer terranes had docked with the craton by the Late Oligocene, when the New Guinea orogeny was initiated. In eastern PNG 


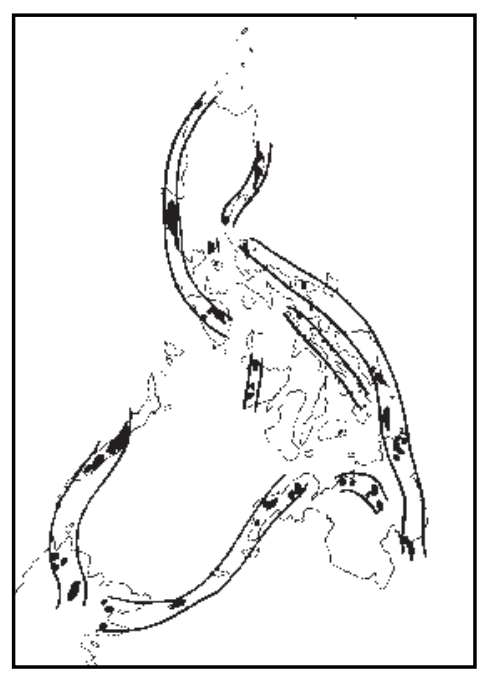

Fig. 123. Ultramafic outcrops of the Philippines (black) and ophiolite belts (Brooks 1987).

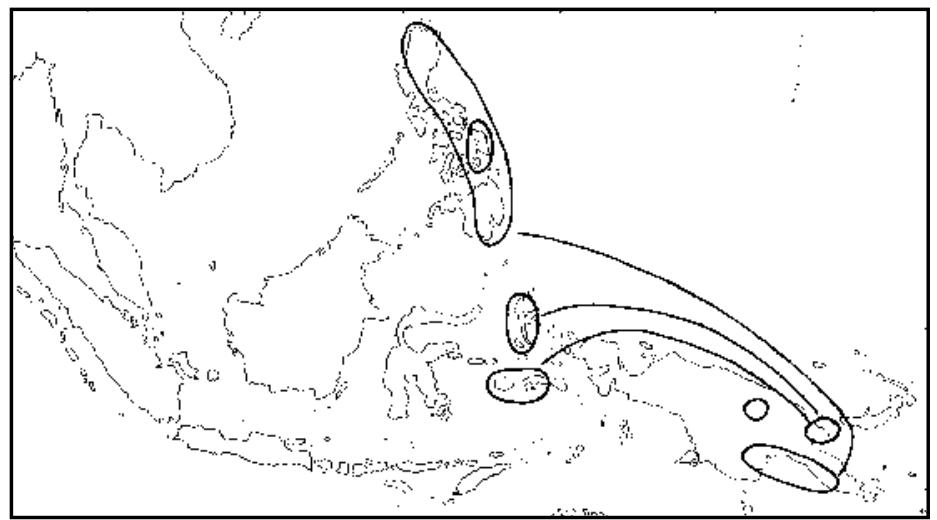

Fig. 124. Casearia Jacq. (Flacourt.): a group of eight species (53-60) keyed together by Sleumer (1954). (The gap in Irian Jaya is filled by 11 other species).

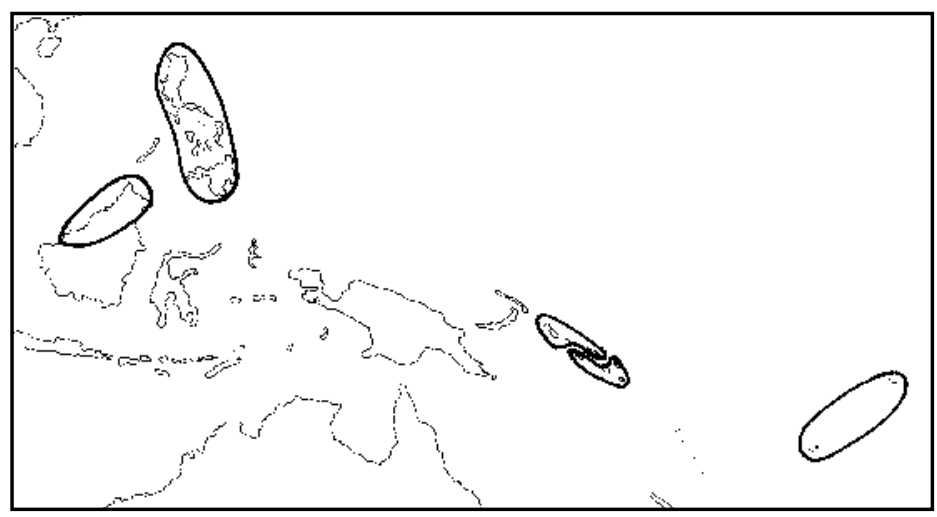

Fig. 125. The Makota goup of five genera (Hemiptera: Lophopidae) (Soulier-Perkins 2000). 
several terranes of diverse origin amalgamated in the Paleogene (Early Eocene if this process caused the metamorphism of the proto-Owen Stanley terrane), and this composite terrane then docked with the Australian craton in the Miocene (cf. Crowhurst et al. 1996). Finally, the Finistere terrane was accreted to the mainland at 3.0-3.7 Ma (Abbott et al. 1994), and rapid uplift continues there. Probably New Britain will dock next. Pigram and Davies (1987) discussed transcurrent movements on faults, and suggested left-lateral offsets of up to $300 \mathrm{~km}$ along the Ramu-Markham and the Bundi Fault Zones.

In Hall's $(1998,2000)$ model, after the Papua and Sepik ophiolites were emplaced in Paleocene/early Eocene, the North New Guinea are terranes originated as the South Caroline Arc, about $4000 \mathrm{~km}$ north of New Guinea in the central Pacific. They converged on New Guinea and eventually docked, but continued to be translated west in the major left-lateral shear zone.

The importance of the craton margin as a biogeographic marker has been stressed above for Ericaceae. It is also important in many other groups, such as Drimys piperita Hook.f. (Winter.) (Fig. 126), where the craton margin separates the different infraspecific 'regional complexes', some of which appear to have been laterally displaced (' $d$ ' in Fig. 126). The complex, hybrid nature of New Guinea is also shown by the three species of Kelleria (Thymel.) there (Fig. 127) (Heads 1990). One species is in New Guinea only on Mt. Carstensz and Mt. Wilhelmina but is also in SE Australia and New Zealand. A second is not on Carstensz or Wilhelmina in the west, or Mts. Scratchley, Victoria and Kenive/Nisbet in the east, but is widespread centrally and in the north at Doormantop, Saruwaged Mts. and Mt. Kinabalu. The third species is a New Guinea endemic sandwiched between the two; it is not on Doormantop or Saruwaged Mts., but is present on Scratchley, Victoria and Kenive. This ecologically inexplicable juxtaposition of the three species deconstructs the geographic entity 'New Guinea' and may be a direct result of the geological formation of the island from separate terranes, and subsequent massive strike-slip movement.

The Ericaceae show the biogeographic structure of New Guinea (and the Philippines) to be one of nested parallel arcs, reflecting massive disjunctions among terranes, and among terranes and the craton (cf. New Zealand, Heads 1989). The parallel arcs structure of New Guinea involves more than two or three arcs (the Inner and Outer Melanesian Arcs of some authors); perhaps there are six or seven (cf. Croizat 1958).

Many other groups also show parallel distribution arcs in E Malesia, inside and outside New Guinea, from the coast to the high alpine, and show the 'deconstruction' of New Guinea clearly. The 'ericoid' Thymelaeaceae (tribe Gnidieae, including Kelleria, above) (Heads 1990) are one example. Another is provided by the three species of mosses in Cyrtopodaceae (Sastre-De Jesús, 1987). The monotypic Cyrtopus (Bridel) Hook.f. is in the D'Entrecasteaux Islands, New Zealand, and Hawaii, Bescherellia elegantissima Duby is in the central PNG Highlands and New Caledonia, and B. cryphaeoides (C. Muller) Fleischer is in the Owen Stanley Mts., Mindanao, CE Australia and Fiji. Here, vicariance within New Guinea is matched by vicariance outside the island.

Cyrtandra J.R. \& G. Forst. (Gesner.) has 500-600 species (Atkins et al. 2001) ranging from Malaysia to Polynesia. The species of W Malesia have hard crustaceous fruit, whereas those of the Pacific turn soft and white at maturity. The meeting ground is in New Guinea and the Solomon Islands (Burtt 1970), where most species have western affinities but a few are allied with species further east. This sort of pattern is usually explained as the result of a 'double invasion' of a modern New Guinea from different centres, but again may be related to the structurally hybrid nature of New Guinea. 


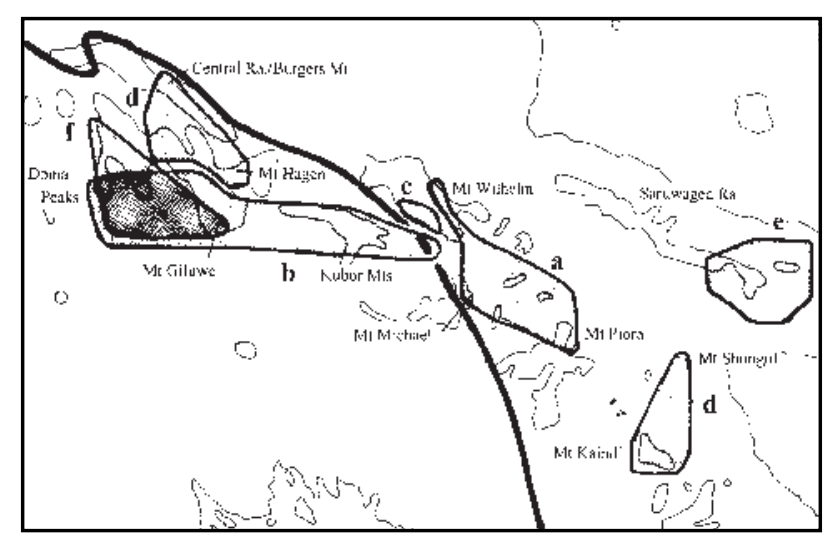

Fig. 126. Regional complexes of Drimys piperita Hook, f. (Winter.) in the PNG Highlands (Vink 1970). Note the two disjunct populations of ' $\mathrm{d}$ '. Land over $2400 \mathrm{~m}$ in fine line, fomer craton margin as thick line.

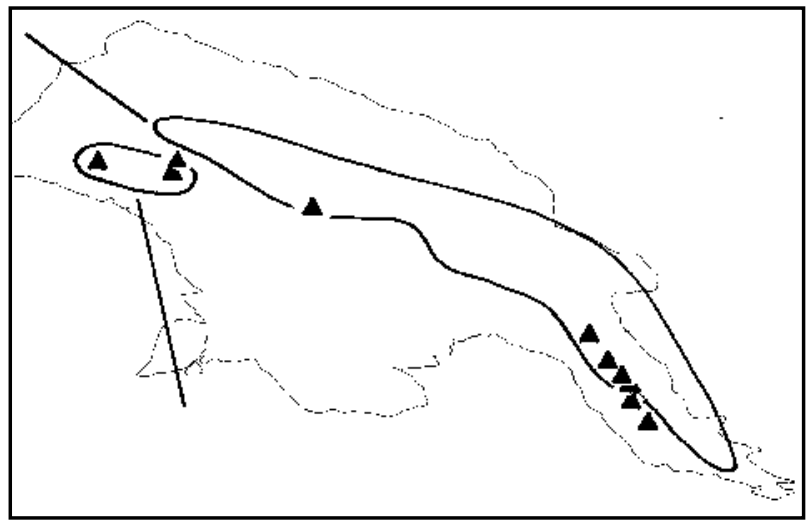

Fig. 127. Kelleria Endl (Thymel.) in New Guinea (Heads 1990). Continuous line at west: K. dieffenbachii (Hook.) Endl., also in SE Australia and New Zealand; continuous line to the east: K. ericoides (Hook.f.) Berggren, also on Kinabalu; triangles: K. patula Merr. \& Perry (whole distribution shown).

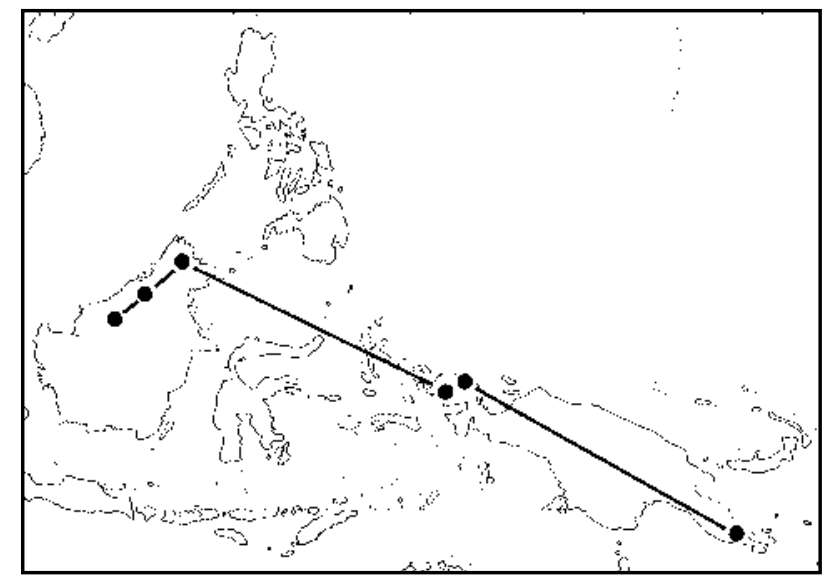

Fig. 128. Distichirops Haegens (Euphorb.) (Haegens 2000). 
The Treubiaceae (Hepaticae) comprise two Pacific genera (D. Glenny pers. comm.). Treubia is throughout Malesia and widespread in the South Pacific, while Apotreubia occurs north of here in SE Asia and North America, but also with one species in the Sepik/Madang area of PNG. This is the only place where the two genera overlap.

\section{Vogelkop}

The Vogelkop region is biogeographically quite distinct from the rest of New Guinea. Knema Lour. (Mysristic.) is through the Philippines, Sulawesi and the Moluccas, but is known in New Guinea only from the Vogelkop (de Wilde 2000). The owl Otus is widespread through the Old and New Worlds, but occurs in New Guinea only at nearby Biak Island (Arfak terrane). However, the Vogelkop is geologically composite. In Ericaceae, the distinction between Arfak/Nettoti Mts. (Arfak and Netoni terranes) and Tamrau/Tohkiri Mts. (Tamrau terrane) is seen clearly in Diplycosia I and III (Figs. 38, 40).

It is probably significant that while the Tamrau terrane is unlike any of the other terranes in western Irian Jaya, there are similar sequences with mid-Miocene intermediate volcanics on the northern flank of the central ranges in eastern Irian Jaya and PNG (Pigram and Davies 1987) (cf. Diplycosia I). This recalls the proposed massive westward movement of the Halmahera arc (Heads 2001b, 2002a).

Holloway and Hall (1998) noted that while de Boer (1995) reviewed geological evidence for a previous more easterly position of the Bird's Head, near the Solomons, other patterns (Myrmephytum Becc.(Rub.), Aporosa Blume (Euphorb.)) are consistent with a westerly position for the Bird's Head (cf. Hall 1998, 2000). Holloway and Hall concluded that 'An alternative most parsimonious hypothesis might be that dispersal occurred ....'. However, before bringing in 'dispersal', it should be acknowledged that the Vogelkop is a geological and biogeographical composite, and even within the northern Vogelkop, the Arfak/Netoni terranes have biogeographic affinities quite different from those of the Tamrau terrane.

The plants and animals of the Vogelkop show many interesting disjunctions. The disjunction between taxa of the Vogelkop terranes (outboard of the craton margin) and those of the Papuan Peninsula terranes (often the Owen Stanley terrane) is seen in plants such as the following (any west Malesian records not given here):

Rhododendron 65: Arfak Mts. - 66: Owen Stanley terrane (Mt. Kaindi).

Dimorphanthera 11. Vogelkop, and Lae to Milne Bay.

Homonoia Lour. (Euphorb.). Nabire (on the Bird's Neck), disjunct on the Papuan Peninsula (van Welzen 1998). (This plant is a rheophyte and is also found along coasts — seeds germinate in salt water. The plant has superb anchorage).

Distichirops Haegens (Euphorb.). Vogelkop, disjunct at Mt Suckling (Dayman terrane) (Fig. 128). (Haegens 2000).

Hartleya Sleum. (Stemonur.). Vogelkop, disjunct south of Lae at Mounts Shungol and Kaindi (Sleumer 1971a, Kårehed 2001).

Picrasma Blume (Simaroub.). Vogelkop, disjunct at the Huon and Papuan Peninsulas (Nooteboom 1964).

Koompassia Benth. (Legum.). Vogelkop, disjunct at Morobe, Gulf and Central Provinces (Verdcourt 1979).

Lycianthes subg. Polymeris sect. Asiomelanesia Bitt. (Solan.). Vogelkop, disjunct at Huon and Papuan Peninsulas (Symon 1984).

Sauropus macranthus Haask. (Euphorb.). Vogelkop, disjunct at the Huon and Papuan Peninsulas and NE Queensland (van Welzen, in press). 
Aglaia teysmanniana (Melia). Vogelkop, disjunct at Huon and Papuan Peninsulas (Pannell 1992).

Alyxia subser, Clusiaceae Markgr. (Apocyn.). Vogelkop and Meos Num Island in Geelvink Bay, disjunct at Bulolo (Markgraf 1977).

Amyema queenslandica (Blakely) Danser (Loranth.). Vogelkop, disjunct at Mount Kaindi and points southeast of there (Barlow 1992).

Polyscias australiana (F.v.M) Philipson (Aral.). Vogelkop and 'Southern District, Papua' (Philipson 1979).

Xanthophytum Reinw. (Rub.). Vogelkop, disjunct at Morobe and the Papuan Peninsula (Axelius 1990).

Romnalda P.F. Stevens (Laxmann.). Japen Island, disjunct at the southern Morobe coast (Stevens 1978b).

Rapanea minutifolia Knoester, Wijn \& Sleumer (Myrsin.). Vogelkop, disjunct at Mount Kaindi, Mount Amungwiwa and Milne Bay (Sleumer 1986).

Xanthomyrtus angustifolia A.J. Scott (Myrt.). Sulawesi, Vogelkop, Mount Kaindi, and (possibly) Normanby Island (Scott 1979).

Calophyllum sil Lauterb. variant (Guttif.). Moluccas and Vogelkop, disjunct at upper Ramu R. and New Britain (Stevens 1980).

Oplismenus hirtellus subsp. imbecillis f. imbecillis (Gram.). Disjunct between Waigeo I. and the Morobe south coast and near Port Moresby (the gap is filled by f. lanceolatus) (Scholz 1981).

In birds:

Melanocharis arfakiana (Finsch) (Dicaeidae) is known only from Vogelkop (Arfak Mountains) and north of Port Moresby (Matsika, halfway between Kairuku and Mount Albert Edward), with sight records on the nearby Kokoda trail (Beehler et al. 1986).

In the birds-of-paradise (Paradisaeidae), Vogelkop - Huon disjunctions occur in species pairs in each of three genera (Astrapia, Paradisaea and Parotia) (Heads 2001b, 2002a).

Zosterops minor tenuifrons (Greenway) is in the Vogelkop (Tamrau Mountains) and also SE New Guinea (Herzog Mountains to Hydrographer's Mountains) (Rand and Gilliard 1967) and a related Vogelkop - Papuan Peninsula disjunction is seen in Pitohui (Dumbacher and Fleischer, 2001).

Similar disjunctions are seen in insects such as the Euops quadrifasciculatus group of Coleoptera (Vogeklkop, Papuan Peninsula) (Riedel 2001).

Diamond (1972) referred to five 'drop-out' bird species which are on the Vogelkop and in PNG but not in the Irian Jaya mountains. Like the Ericaceae 'drop-outs', these disjunctions can be explained by movement and accretion of terranes rather than extinction of central populations.

Possible connections between the Vogelkop and the D'Entrecasteaux Archipelago, $2100 \mathrm{~km}$ to the east, are indicated by two pairs of Rhododendron species keyed together by Sleumer (1966):

Rhododendron 128: Vogelkop and Wissel Lakes, 129: Goodenough I.

Rhododendron 248: Arfak Mts, 247: Milne Bay. 
Archidendron tenuiracemosum Kanchira \& Hatusima (Legum.) (Moluccas, Vogelkop) is a 'very close' sister species of A. hooglandii Verdcourt (D’Entrecasteaux Archipelago) (Nielsen et al. 1984).

Salacia forsteniana Miq. (Celastr.) is disjunct between the Moluccas/Waigeo and Normanby I., Milne Bay (Ding Hou 1964).

In Kibara Endl. (Monim.) a group of four species in Philipson's (1986) key (under couplet $8 b$ ) are only on the Vogelkop and the D'Entrecasteaux/Louisiade islands.

The form of Podocarpus spathoides cited above disjunct between the Moluccas and the Louisiades has a similar pattern.

Pandanus amboinensis Warb. (Pandan.) occurs at the Moluccas and Vogelkop (Manokwari) and is disjunct at Milne Bay (Mt Dayman, Goodenough I., Woodlark I.) (Stone 1992).

A similar disjunction (Vogelkop-D'Entrecasteaux) occurs in the perciform fish Plesiops corallicola (Mooi 1995).

A related Vogelkop disjunction is illustrated by other Araliaceae, in which Frodin (1998) recorded Osmoxylon Boerl. disjunct between the Vogelkop and the Bismarck Archipelago, and Gastonia serratifolia (Miq.) Philipson disjunct between the Vogelkop and the central Solomons. Frodin concluded that these patterns possibly relate to movement along the Sorong Fault, a strike-slip zone initiated at $20 \mathrm{Ma}$.

A similar disjunction in Dimorphanthera V: Waigeo I. (off the Vogelkop) - New Ireland, recalls that of Epithema Blume (Gesner.): Geelvink Bay - Solomon Islands (Rennell I.) (Burtt 1998) and the genus Japenoides Oldroyd (Diptera: Tabanidae): northern Vogelkop, Biak and Japen Is., disjunct at New Britain, the Solomons, Vanuatu and Fiji (Mackerras 1971).

The parallel arcs connecting different parts of New Guinea with different parts of the Philippines, C Sulawesi etc. all show the deconstruction of New Guinea. In a similar way, Australia does not really exist as a biological or geological entity; for example, in Proteaceae, NE Australia taxa are allied with South American plants, whereas SW Australian plants are allied with African taxa (Croizat 1964, Hoot and Douglas 1998).

\section{The former craton margin in New Guinea}

Kalkman and Vink (1970) compared the Ericaceae floras of four neighbouring mountain ranges in the Highlands of PNG (Doma, Giluwe, Wilhelm, and Kubor). They discussed both the 'conspicuous absences' and the 'remarkably high' number of taxa known from only one of the ranges (and other parts of New Guinea). They clearly demonstrated the great differentiation between ranges, but showed that this is not due simply to local endemism on every mountain top - a common misconception.

Many biogeographic breaks in the Ericaceae of this region occur at the former craton margin where similar breaks occur in many other taxa. For example, the shrub Drimys piperita entity 'reducta' (Diels) Vink: Wissel Lakes, Mount Wilhelmina, Mount Giluwe and the Kubor Mountains, and entity 'subalpina' Vink: Mount Wilhelm, act as a pair of 'replacing taxa' (Vink 1970). Vink reported the 'unexplained circumstance' that the form of reducta most distinct from subalpina is found at the Kubor Mountains (the locality closest to Mount Wilhelm), while the form which connects the two morphologically, entity 'subpittosporoides' Vink, is restricted to Mount Wilhelmina. A very similar pattern is seen in the closely related pair Grammitis ceratocarpa Copel. (Snow Mts., Mt. Wilhelm, Huon Pen.) and G. salticola Parris (Mt. Giluwe) (Parris 1983). Again, this arrangement could be explained by (right-) lateral movement of terranes. (Movement is right-lateral or dextral if rock on the other side of the fault from the observer has moved to the right). 
Other examples of plant differentiation around the former craton margin include species of orchids (Corybas Salisb., Dendrobium Sw., mapped in Heads 2001b: Fig. 32; Glossorhyncha Ridl., Fig. 33), Rhododendron (Fig. 34), Compositae (Tetramolopium Nees., Fig. 35; Olearia Moench, Fig. 36) and Rubiaceae (Amaracarpus Blume, Fig. 37).

Stevens (1985) listed seven species distributions in the PNG Highlands which 'suggest that long distance dispersal or extinction has produced anomalous distribution patterns.'

Of these, 41. R. hooglandii is known from the Kubor Mountains and Mount Kerigomna, but not on the nearby Mount Wilhelm. This absence is an 'apparent anomaly' and the floristic differences among the mountains are 'apparently inexplicable' and 'particularly perplexing'. But this overlooks the major tectonic division in New Guinea, lying between the craton and the accreted terranes, and marked in this area by the Bismarck Fault Zone (for terranes etc. see maps in Heads 2001b). Diamond (1972) overlooked this same tectonic boundary in accounting for differences between the birds of Okapa and Mount Karimui. The Wilhelm batholith and associated metatamorphics form a separate block from the former craton (Kubor Mountains etc.) and Mt. Kerigomna is right on the margin.

Sp. 191 R. atropurpureum is known only from the Kubor Mountains and Mount Wilhelm, but the two populations shows interesting differentiation, with the Kubor Mountains plants having smaller flowers (P.F. Stevens pers. comm. 28-8-01; Stevens does not believe current introgression from $R$. womersleyi is a likely explanation for this).

Sp. $170 R$ vitis-idaea is on Mts. Wilhelm, Sarawaged, Amungwiwa etc. (as mapped in Heads 2001b), and there is an additional record from Porget ( $R$. 'vandeursenii'). This is a classic example which ranges right up to the former craton margin from the north and east.

Sp. 148 R. saxifragoides comes right up to the margin from the west, reaching Giluwe but notably absent on Mt. Wilhelm.

Thus at least four otherwise inexplicable distributions all show a break at the main tectonic boundary in New Guinea.

\section{Sepik terrane}

Steven (1985) noted the importance of the Sepik Basin, PNG, where many endemics occur on accreted terranes. These include poorly known taxa such as Rhododendron 48 (near Mt Stolle), Vaccinium 235 (Hunstein Mts), Dimorphanthera 9 (Schrader Mts.) and 18 (Sepik), all known only from their types which were all destroyed in World War II. Huynh (1999) has recently described as many as six new endemic species of Freycinetia Gaudich. (Pandan.) from the Hunstein Mts (all collected by Wayne Takeuchi) and the monotypic Paramyristica de Wilde is endemic to the Sepik basin (de Wilde 2000).

\section{Northwestern Owen Stanley terrane: upper Watut Valley}

The northwestern margin of the Owen Stanley terrane is well-marked biogeographically, for example by Dimorphanthera 11: Port Moresby - Lae/Bulolo area. Affinities skirting the northwestern edge of the Owen Stanley terrane are also seen in plants of drier areas (D. Frodin pers. comm., Rhynchosia minima (L.) DC. (Legum.), Capparis quiniflora DC., van Steenis 1978a: Figs. 14, 21), as well as mangroves (Osbornia F. Muell. (Myrt.), van Steenis 1978a; Fig. 22) and aquatic taxa (Torrenticola Domin (Podostemon.), known from Queensland, Port Moresby (Roona: Laloki R.) (van Steenis 1949), and Baiune R. near Bulolo (pers. obs. 1981)). 
Many other plants of SE New Guinea reach their northwest limit here, for example, distinctive genera in Sapotaceae (Magodendron Vink, Vink 1995), Rubiaceae (Anthorrhiza Huxley \& Jebb, Huxley and Jebb 1991), Monimiaceae (Kairoa Philipson, Philipson (1980) and Malvaceae (Cephalohibiscus Ulbr.) (Fryxell 1980, possibly also on the Huon Peninsula).

The upper Watut area is the northern limit of the Owen Stanley terrane schists and is marked by mid-Tertiary granodiorite intrusions which form the mountains bounding the Watut catchment: Shungol, Missim, Kaindi, and Amungwiwa. Each of these is a centre of endemism for different groups, such as Rhododendron 66 (Mt. Kaindi), sp. 254 (Wagau, Mapos (Snake R.), Zenag, Wau, Kaisenik), Dimorphanthera (= Vaccinium sect. Pachyanthum) 2A (Bulldog Road), var. 44b (Gurakor), and Agapetes var. 2a (Mt. Amungwiwa), 11A (Mt. Shungol).

There are as many as six Solanum species locally endemic in the upper Watut (Symon 1985). Other plants here include Langsdorffia Mart., known only from Mount Missim, Madagascar, and tropical America (Hansen 1974, Streimann 1983), and Hartleya Sleum. (Stemonur.), known only from Mount Shungol with sterile specimens from the Vogelkop and its nearest relative, Gastrolepis Tiegh, in New Caledonia (Sleumer 1971a, Kårehed 2001). As well as being a boundary, Mount Missim and the Herzog Mountains (= Mount Shungol etc.) comprise a centre of endemism for bird subspecies in Mirafra, Pachycephala, Colluricincla, Melidectes, and Rhamphocharis (Rand and Gilliard 1967).

Other groups showing craton/accreted terrane differentiation include the following:

Dendrobium sect. Latouria Bl. (Orchid.) has 48 species, all except four of which are in New Guinea (Cribb 1983). Within New Guinea it has important centres of diversity on the accreted terranes. There are 8 species groups, of which the following five are more or less restricted to the accreted terranes: Group 1 (except one species widespread from Java to Samoa), Group 2 (except one record in the Upper Fly R.), Group 3 (tracking the margin at Weyland Mts., Wissel Lakes, and Chimbu Province), Group 6 (except one record on Wilhelmina, in PNG ranging up to the margin at Central Range and Wapenamanda), and Group 8 (ranging up to the margin at Rouffaer R., Central Range, Minj, and Kundiawa).

Only Group 5 occurs mainly south of the craton margin.

Only Group 4 and Group 7 (one species only) are widely recorded both north and south of the craton margin.

Helmholtzia F. Muell. (Philydr.) is in the Moluccas, the Vogelkop (Fakfak), Bernhard Camp (Rouffaer terrane), Hunstein Mts. (Sepik terrane) and NE Queensland (Johns and Hay 1981). Its closest relative is Orthothylax (Hook.f.) Skottsb. of SE Queensland, and this connection between the accreted terranes and the McPherson-Macleay Overlap (also accreted terrane) is standard (cf. the main diversity of bowerbirds, Ptilonorhynchidae), complementing the other track between southern cratonic New Guinea and the far north of Queensland (cf. the main diversity of birds-of-paradise, Paradisaeidae; Heads 2001c) .

In a similar pattern to that of Helmholtzia, Sphenostemon arfakensis (Gibbs) Steen. \& Erdtman of the Vogelkop (Arfak Mountains) is closest to S. lobosporus (F.v.M.) L.S. Smith of Jimi Valley (Jimi terrane), Milne Bay and Queensland (van Steenis 1986). 
Following an assessment of biodiversity of Grammitis Sw. in Heads (2001a) based on data in Parris (1983), Dr. B. Parris (pers. comm.) commented that Grammitis seems more diverse on Mounts Giluwe and Hagen, and probably the main Irian Jaya mountains (all these are on the craton), than on Mt. Wilhelm - Saruwaged Mts. This recalls the distribution of 148. Rhododendron saxifragoides which stops mysteriously at Mt. Giluwe and is not on Mt. Wilhelm. A similar pattern is seen in Coprosma brassii (Rubiaceae), widespread from Mt. Carstensz to Mt. Hagen (Gardner 2002).

However, several groups in Grammitis show a different pattern, vicariant to this one and skirting the main ranges and the craton to the north on the accreted terranes. Thus, the G. adspersa subgroup is in the Arfak Mts. - Doormantop - Hunstein Mts. Owen Stanley terrane, vicariant with the New Britain - New Caledonia link in the G. pseudaustralis subgroup. The Doormantop species is also in SE Sulawesi, Java and Aceh. G. plerogrammoides also avoids the main (craton) ranges, but ranges right up to the border from the north at the Baiyer-Jimi divide north of Mt. Hagen. Likewise, the G. reducta subgroup is only north of the craton (Doormantop, Star Mts on the margin, Watut/Aseki Divide), and the G. lasiosora subgroup (Arfak Mts. - Doormantop - Mt. Piora) also avoids the craton. It seems unlikely that this pattern can really be explained by ecology.

Parris (1983) described G. collina Parris, endemic at Baiyer-Jimi divide just outboard of the craton, as 'superficially similar' to G. rupestris Parris endemic to Laloki near Port Moresby, also just outboard of the craton. Parris treated the two together, but felt they are probably not closely related. Whether or not they are in fact close, this tracking of the craton margin is a common biogeographic connection despite the totally different ecology (altitude, rainfall etc.) at these two sites, and resembles the western limit of G. oblanceolata: Astrolabe Range, Aseki, and Kum (Mt. Hagen).

\section{Chronology}

Specht and Womersley (1979) concluded 'It is probable that the forerunners of Malesian heathland elements had already evolved on the supercontinent of Gondwanaland before it began to break up into tectonic plates ... The heathland species of Malesia appear to have been derived from the ancient flora which existed on the northeast section of Gondwanaland. Two distinct groups resulted when Gondwanaland split assunder - one on the Indian plate, the other on the AustralianNew Guinea plate'. This view (although it overlooks the main massings of Ericoideae in South Africa and Vaccinioideae around the Pacific) is supported here.

In the fossil record Rhododendron seeds have been recorded as far back as the Paleocene of southern England (Collinson and Crane 1978). This early Tertiary 'age of fossilisation' could easily indicate an 'age of existence' in the upper Mesozoic, which is compatible with Nixon and Crepet's (1992) report of the oldest fossil flower of Ericalean affinity from mid-Cretaceous (Turonian, $87 \mathrm{Ma}$ ) deposits. This supports the idea that Mesozoic tectonics are fundamental in explaining the main global pattern of the large genera and tribes in Ericaceae.

The age of the angiosperms is unknown. Gymnosperms have a much older fossil record (320 million years) than angiosperms (130 million years). However, recent work (Chaw et al. 2000, Bowe et al. 2000) indicates the extant gymnosperms are a monophyletic group. Chaw et al. (2000) concluded by asking 'Are the angiosperms substantially older than the current fossil record indicates, or did they arise in the Jurassic from the Bennettitales, Caytoniales, or some other extinct group of seed plants?' Likewise, Boew et al. (2000) wrote that their own study 'implies that angiosperms originated some time along a very long stem lineage. This would reach back possibly to the Carboniferous ...'. 
Modern phylogeography (Avise 2000) often claims to be testing whether a distribution is due to dispersal or vicariance. However, the molecular divergences are nearly always calibrated using a literal reading of the fossil record, that is, a group whose oldest fossil $\mathrm{x}$ is $\mathrm{y}$ years old is assumed to actually be y years old. This is a key procedure of the dispersalist school, so a study based on it can hardly be considered an unbiased test of dispersal vs. vicariance. Occasionally authors have calibrated the sequence data using a simple equation of biogeography and geology. For example, trans-Tasman Sea disjuncts have been taken to be the same age as the opening of the Tasman. This approach is better but still simplistic, as trans-Tasman taxa could be much older than the opening of this sea.

\section{Mangrove ancestry of Malesian Ericaceae}

The occurrence of Rhododendron and other Ericaceae in the mangroves of W Malesia (but not E Malesia) is usually assumed to have resulted from a secondary invasion of the mangrove after the evolution of the group. However, many Ericaceae seem quite at home there. $R$. brookeanum (photos at www.vireya.net/R.brookeanum.htm) and $R$. longiflorum (there is a plant growing in the Royal Botanic Gardens Sydney) even look like mangroves, with long, elliptic, acute, coriaceous leaves like, say, a Bruguiera. The mangrove and coastal Ericaceae species do not comprise a related group, but may retain relictual traces of an ancestral ecology.

Gentry (1987) criticised the common misconception in which 'Mangrove epiphytes are implied to be basically plants from nearby terrestrial communities that transgress into the mangroves', and emphasized that many epiphytes, such as the entire genus Tuberostylis Steetz. (Compositae), seem unique to mangroves.

The mangrove and back-mangrove are much richer than is often realised. For example, in Sapindaceae, 9 of the 42 Malesian genera (21\%) occur in or around mangrove and 11 others (26\%) are known from coastal cliffs and sands (data from Adema et al. 1994). In New Guinea Euphorbiaceae 11 out of 47 genera (25\%) are recorded in or around mangrove (Airy Shaw 1980). In Malesia, Icacinaceae (Sleumer 1971a) have 6/12 genera in or around mangrove or on coral limestone at sea-level, Celastraceae s.1. (Ding Hou 1964) have 5/19 and Simaroubaceae (Nooteboom 1964) 5/9 genera represented in similar habitats. In birds of paradise, at least five out of 14 genera of Paradisaeinae $(35 \%)$ are found in mangrove and associated vegetation.

In these and other birds and trees the New Guinea mangrove shows clear affinities with terrestrial rainforest, drier forest and secondary forest, and there is also an obvious link between mangrove and the more or less freshwater swamp forests and peat swamp forests found along the Mamberamo-Sepik depression in New Guinea. In the coastal lowlands, mangrove, beach forest, 'lowland rainforest' and freshwater swamp forest species often grow together in different microhabitats in a complex association not shown in text-books.

There are also important phylogenetic ties between dry-land plants and those of shore and aquatic environments. For example, the mangrove palm Nypa Steck. is basal to all the other palms (except Calamoideae) (Hahn 2002). In dicots, molecular studies (Savolainen et al. 2000) indicated that the mangrove family Rhizophoraceae (with Erythroxylaceae) is basal to a very large group of 34 families (termed the Malpighiales by Savolainen et al., 2000, but including the Euphorbiaceae - much larger and better known than Malpighiaceae, Flacourtiaceae, etc.). Again, this seems less consistent with a secondary 'invasion' of the mangrove than with Church's ideas (Mabberley 1981) on the evolution of land plants from shore plants through tectonic uplift ('The discussion of any theory of 'migration' should be preceded by the examination of the possibilities of a mechanism of 'transition in situ"). 
A good example of a coastal plant possibly stranded inland is Chaetocarpus Thw. (Euphorb.), which ranges from India and Sri Lanka to Peninsular Malaysia and Borneo. It is common along the coast in NE Malaysia and according to van Welzen (1994b) the many inland collections 'may reflect old Pleistocene shorelines'.

For many years it was thought that angiosperms must have originated in the mountains (thus explaining the lack of fossils), but paleobotanists (Retallack and Dilcher 1981) have supported a coastal origin of the group. Plants of the mangrove, back-mangrove and freshwater swamp occur in a wide range of oligotrophic, periodically inundated soils, including both acid sands and basic, calcareous material derived from coral reefs. Plants of the shore and its hinterland, including cliffs and rocks, are often tolerant of some drought. The very diverse flora has a high potential as an ancestral community, especially during phases of marine transgression, in contrast with the climax vegetation of the high montane cloud forest and its narrow endemics committed to a 'specialist' environment.

Evidence of uplift and stranding of taxa inland and on mountains cited above for Malesia can be seen in many countries. For example, in Nijmegen in the Netherlands 'for some mysterious reason the gulls have chosen one of the numerous fens on the western edge of the city as their breeding place. A biological memory from primeval times, when the sea had here her strands?' (Seveke 1955).

In Australia, 'a considerable portion of southern and central Australia was submerged by sea in Mesozoic and Tertiary times.' Specht (1981) inferred that 'Remnants of the salt-marsh flora along the estuarine parts of the Tertiary coastline remained far inland when the sea retreated'. Specht cited Avicennia marina stranded $40 \mathrm{~km}$ inland from the Western Australian coast, and also saltmarsh floras $500 \mathrm{~km}$ inland.

Salicornia L. (Chenopod.) and Frankeniaceae are usually maritime shrubs, but in the Andes both have cushion species occurring at over $4200 \mathrm{~m}$ altitude (Ruthsatz 1978).

In the West Indies, Stoddart et al. (1973) described inland mangrove vegetation in Babuda including Laguncularia Gaertn.f., Conocarpus L. and a closed woodland of Rhizophora L. on old lithified beach ridges that have no connection with the sea. This raises 'problems of the history and development of these communities ... It is clear, however, that mangroves, including Rhizophora, can grow in environments very different from those usually associated with mangrove vegetation'.

The Russian author Tolmachev (1970) described the process of formation of highland floras, in which 'the height rises with its vegetational cover, namely with its flora, which will ultimately become orophytic ... the adaptational amplitudes of the different species and their hereditary conservatism varies. Accordingly, some species of the rising highland will remain without any apparent changes in their nature, whereas other species, adapting to their new conditions, will be transformed into new 'daughter' species, and finally, other species, being unable to adapt to the changing conditions, will perish'. Tolmachev emphasized the fundamental significance of the 'Floral and vegetational character of a certain area on the earth's crust before its rise to the ultimate altitude. The importance of this moment is frequently not fully appreciated in investigations of the origin of orophytic floras, although their nature (especially that of the more recent formations) will largely depend on it'. 
Personal observations made clambering through mangrove and subalpine forest in New Guinea indicate that these densely-branched, sometimes impenetrable communities share architectural similarities, and may supply equivalent habitat for birds. For example, stilt and prop-roots are frequent in both (e.g. montane Rhizophoraceae, Crossostylis J.R. \& G.Forst.; Soepadmo's 1972: Figs 19, 29 showing montane Lithocarpus spp.). In birds, taxa such as the bird-of-paradise Manucodia comrii Sclater occur in both mangrove and subalpine forest.

Why are there no mangrove Ericaceae in E Malesia? Perhaps they have all been uplifted, as seems to be the case for species like 238. R. leucogigas in northern New Guinea. Lamiodendron Steen. (Fig. 129), a 'most remarkable bignoniaceous tree' (van Steenis 1957, 1977), is a monotype from Milne Bay (Normanby I., Rossel I., Alotau) and Popondetta, and is 'geographically unexpected and rather isolated'. Its affinities are probably with the African - SE Asiatic - W Malesian genera Fernandoa Seem., Radermachera Zoll. \& Mor. and Stereospermum Cham., plants of rocky coasts, limestone, rainforest and drier forest, but it differs from all these in its exceedingly showy flowers (the tree is 'worthy of introduction into cultivation'). In Normanby I. it was found 'forming a community on a gravel bank behind the beach fronting swamp forest', and it is also known from sago swamps, lowland rainforest and disturbed forest. It appears to be a relic mangrove-associate, left stranded in the east far from its western relatives, the whole lineage having been unable to survive any uplift at all in central New Guinea (unlike other Bignoniaceae such as Tecomanthe).

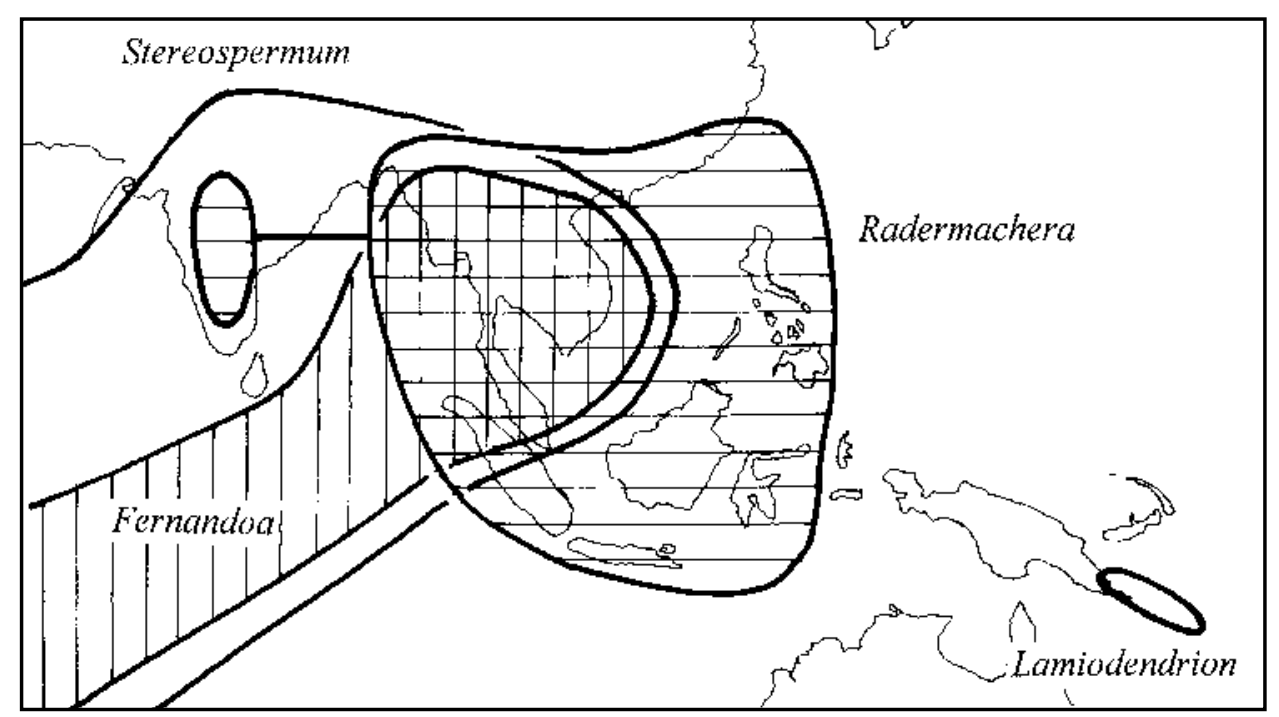

Fig. 129. Four related genera of Bignoniaceae tribe Tecomeae: Stereospermum Cham., Radermachera Zoll. \& Mor., Fernandoa Seem. and Lamiodendrion Steen. (van Steenis 1977). 


\section{Terrane tectonics and biogeography}

Van Steenis (1934a) made the crucial point that 'Plant geography does not need to be tied to the apron strings of other branches of natural history. It is an independent study having at its disposal important objective material, which enables it to develop and come to conclusions of its own'. This approach is in contrast with that of chancedispersal biogeography, which remains in thrall to phylogeny, geology, ecology, and anthropology etc. and has no principles of its own, except a concept of 'chance' in which, given enough time, anything becomes possible. Van Steenis's alternative approach is essential if a real science of biogeography, capable of analysing localities and the relations among them, is to advance.

In fact, biology has potentially far more spatial information than geology; most of the different rock types on earth are composed of only a hundred or so minerals in combination, whereas the living communities involve millions of organic species. In addition, life is less easily eroded than inorganic strata and often remains more or less in situ during phases of uplift, erosion, subduction, metamorphism, intrusion, vulcanism etc., using its ordinary means of survival (cf. Craw et al. 1999, Figs. 2-5, 2-12). The problem is that biology often does not analyse the spatial data it already has available (e.g. for Ericaceae) simply because 'chance-dispersal' is assumed to have rendered distributions meaningless and there cannot be any pattern by definition. It should be remembered that biogeographic data were used to argue for continental drift decades before this was 'discovered' by American geologists in the 1960s.

It is easy to show that geographical distribution has been neglected in biology. There is no equivalent in Biology courses of the standard first-year mapping project in Geology and distribution maps did not even become a common feature of taxonomic monographs until the 1960s. Many modern monographs and floras have no maps at all.

The first integrations of biogeography and terrane tectonics, in New Zealand (Craw 1982, 1985, Heads 1989, 1997, 1998), gave interesting results, and biologists have recently begun to use accreted terranes in explaining distributions of New Guinea plants (van Welzen et al. 1992, van Welzen 1997, Vermeulen 1993, Turner 1995, Heads 1999, 2001a), invertebrates (de Boer 1995, de Boer and Duffels 1996a, b, Polhemus 1996, Polhemus \& Polhemus 1998, Novotny \& Missa 2000) and vertebrates (Michaux 1994, Heads 2001b,c, 2002a,b).

Discussing mammals, Flannery (1995) wrote that 'tectonic movements have been the prime cause of many of the zoogeographic patterns that we see in New Guinea today'. The northern coastal ranges include 'the most peculiar and inexplicable mammal distributions found anywhere in New Guinea'. For example, the range of the marsupial Pseudochirops albertisii (Peters) (Arfak Mountains, Japen Island, Weyland, Cyclops, Bewani and Torricelli Mountains) is 'quite enigmatic ... Without massive tectonic movements its distribution would be inexplicable, as its present distribution is disrupted by ocean (Geelvink Bay), massive rivers (e.g. the Mamberamo) and swamp (the Meervlakte). Not even the most extreme late Pleistocene climatic change could account for its present distribution. Yet the tectonic changes necessary to produce its distribution are so massive ... as to be breathtaking'.

In traditional plate tectonics Malesia is interpreted as the suture zone of just two continental blocks, with 'Asian' groups like Rhododendron entering Papuasia from the west within the last $20 \mathrm{Ma}$. Hall (1998) agreed that there were originally two principal biogeographic regions, Australasia and Asia, which were physically separated and subsequently became connected, and that up to at least $15 \mathrm{Ma}$ there was 'probably very little land' between Borneo and Australia. This seems unrealistic, and terrane models with their potentially great complexity are more 
satisfactory for biogeography than earlier, more simplistic plate models. For example, the 32 accreted terranes in New Guinea all have endemics and are of general biogeographic interest.

Hall (2000) warned that while the idea of terranes is a popular one, sometimes the terranes are interpreted as simply the carriers of land plants and animals. It is probably more complex than this, with the terrane margins (e.g. as zones of suturing, metamorphism and physiographic change) being more important than the terranes as geographical entities.

As Hall (2000) wrote, 'New Caledonia serves to remind us all of some fundamental geological and biogeographic problems in the region ... there is apparently an ancient Gondwanic flora, and other strange features of the flora and fauna seem to imply some land there since the late Cretaceous. On the other hand it is difficult to find any geological evidence that New Caledonia was above sea-level until the late Eocene. How do we resolve this dilemma?' Hall suggested that 'it indicates that we should remain cautious about simple and definitive answers ... and we should all remain critical of our data and beliefs ...', which is true of course but gives no real answer. Instead it is suggested here that in places like New Caledonia and New Guinea the biological evidence is much more complete than the geological, due to removal of strata by erosion, tectonic narrowing, and subduction.

Corner (1963) argued that the fig flora of New Caledonia holds a 'master key' to the past: it has high and peculiar endemism but lacks nearly all the species and sections which would be expected if it had simply been an extension of the Papuan, Queensland or Solomon Islands flora. 'Such precise evidence, negative and positive, must deny any hypothesis of chance colonisation ... Croizat's victory is the defeat of chance dispersal: he has given us whereon to stand'.

Discussing 'Wallacea', or the central Malesia region, Hall (2000) emphasized that important tectonic features can disappear within short periods leaving almost no trace, and that 'In areas of volcanicity there is always the possibility there might have been ephemeral land ...'. Individual volcanoes are geologically ephemeral, usually lasting less than $1 \mathrm{Ma}$, but even small, transient volcanoes can be very effective in preserving flora and fauna, as Philipson (1970) noted for the central Pacific. Tectonic narrowing in New Zealand and New Guinea has led to many terranes (much larger units than volcanoes) being much smaller now than they were originally. Some are merely remnant slivers, while others have probably disappeared entirely. However, their biota, like that of the volcanoes, may be able to survive great physiographic change by being 'scraped off' at subduction zones.

Hall (2000) suggested that biogeographers could contribute to testing tectonic models 'by, for example, mapping distributions of fossil plants and interpreting their environment'. However, both these approaches are probably of rather limited value; Hall himself noted that the fossil record is poor or non-existent for most plants and animals and this is actually true for the vast majority. It is much more important to map the living organisms, especially the diverse groups.

Holloway and Hall (1998) wrote that 'The reluctance of some biogeographers to consider the palaeontological data is something that geologists find difficult to understand.' Much palaeontological data and interpretation (unlike work on tectonics) are riddled with dispersalist assumptions, but panbiogeographic studies make a point of integrating data from fossil (when available) and extent taxa (e.g. Heads 1989: Fig. 16d showing fossil and extent brachiopod taxa; Fig. 19 comparing Mesozoic molluscs and the plant Coriaria L.). What perhaps riles palaeontologists is the fact that panbiogeographic analysis does not privilege the fossil data to the great extent that the centre of origin theory does. In this theory, the oldest known fossil of a 
group represents the ancestor and occurs at the place and time of the group's origin. Fossil data can provide essential evidence for morphogenetic studies but are almost always woefully inadequate for biogeographic analysis. For example, fossil data of Ericaceae, or any plants for that matter, contribute practically nothing to analyzing the relationships among the mountain floras of New Guinea. Despite this, Holloway and Hall (1998) claimed that 'Hypotheses of strict terrane fidelity by biotas are not well supported by fossil evidence ...' ', which is probably true, but only because there is hardly any fossil evidence of these groups to begin with.

Hall (2000) also suggested that for biogeographers to test tectonic models 'there must be a focus on plants and animals which have difficulty in dispersing'. But this makes unnecessary assumptions. It is better to study a wide range of well differentiated groups without making prior assumptions about dispersal. In any case, as dispersalists know, all organisms, even snails and worms disperse, and given enough time any distribution becomes possible.

Centre of origin biogeography often takes as key just two parts of geology, which are arguably among the weaker in the subject and which are both based on negative evidence. Centre of origin models take the age of fossils to represent the age of taxa, when in fact there is no relationship (except fossils will nearly always be younger than their taxon); and when geologists say there is no evidence for land during a certain period, centre of origin biologists take this to mean there is evidence for no land. Neither assumption is accepted here.

Holloway (1998) suggested that 'The types of distribution patterns in the New Zealand biota that have been related to tectonic arc structures in the islands (e.g. Craw 1989) are also manifest in the distributions of plants introduced by Europeans, and suggested for these to have a climatic basis (Wilson et al. 1992)'. Holloway and Hall and (1998) wrote that these introduced plants 'can reproduce in response to climate the 'parallel arcs' patterns shown by indigenous plants', and this supposed similarity is used to support their conclusion of 'absence of widespread terrane fidelity'. The distributions of the introduced species mapped by Wilson et al. (1992) reflect the westeast decrease in rainfall in the South Island and the hot, sunny climate of the central regions, as indicated by Wilson et al. (1992). Despite Holloway's claim, these introduced plants and the local climatic zones they follow do not have similar distributions to the highly complex but repeated patterns of the local and regional endemics. This is why the biogeography of the last groups is so interesting (Heads and Patrick, in press) and why for many years ecologists have invoked different kinds of historical factors to explain the distributions.

Holloway and Hall (1998) suggested that panbiogeographers such as Heads (1989) 'postulate a high degree of terrane fidelity by biota', but correlations of a great number of New Zealand and New Guinea endemics with terranes is more of an observation than a hypothesis. Holloway and Hall (1998) concluded by admitting that: 'Some degree of terrane fidelity is suggested ... for groups such as cicadas (de Boer 1995), some plant taxa (Ridder-Numan 1998, on Borneo) and water bugs (Polhemus and Polhemus 1998), but it might be dangerous to extrapolate this to a generality.' It would certainly be dangerous for dispersal theory. Birds-of-paradise (Heads 2001b,c, 2002a) and Ericaceae are two more groups which illustrate a high degree of geological control.

\section{Centres of origin, chronology and adaptation}

This paper has questioned certain current concepts in biology. With respect to the spatial component of evolution, a concept of 'dispersal' as physical movement from a point centre of origin is best replaced by one of vicariance mediated by tectonics, especially rifting, accretion and uplift. As George (1987) pointed out, it was 
discrepancies between theories of centres of origin, in particular how one derived the centre of origin, that led to the development of the generalised tracks/vicariance approach. Authors like Darwin (1859), Matthew (1915), Frey (1993) and Briggs (1999, 2000) assume that the most advanced species occur at the centre of origin (and outcompete the primitive ones which migrate away), whereas other authors such as Mayr (1942), Hennig (1966) and the modern phylogeographers (Avise 2000) assume that the most primitive taxa occur at the centre of origin, and the advanced ones have migrated away ('Progression Rule'). This stand-off within the dispersal school has not even been recognised yet and may well continue for another 140 years, but neither assumption is used in vicariance cladistics (e.g. Platnick 1981) or panbiogeography.

Other phenomena are also difficult to understand under the centre of origin/migration theory: 232: Rhododendron cuspidellum Sleum is a weedy, pioneer species, locally common in secondary forest, but it is also a very local endemic known only from the Wissel Lakes on the edge of the craton. Some very localised species of Erica are also abundant in their area, for example, Erica urna-viridis $\mathrm{H}$. Bolus is known only from one plateau on the Cape Peninsula, but is very common were it does grow and forms fairly large colonies (Schumann et al. 1972).

In a centre of origin view of ecology, Luteyn (2002) concluded that Ericaceae became epiphytes as a result of 'canopy invasion', and likewise 'migrated into higher-altitude, Andean habitats, which were unoccupied'. Instead, it is suggested here that the canopy was always, already occupied by epiphytes such as the ancestors of Ericaceae, and likewise that the 'Andean' habitats were always, already occupied by the ancestors of Ericaceae, even before they were uplifted to alpine heights.

With respect to the chronology of evolution, it now seems that while Quaternary events may have locally modified distributions and abundances they have had little effect on the evolution of modern groups, which is the result of Mesozoic and Tertiary events. Hall argued that 'DNA studies offer one way of determining a time-scale for biological development', but this is probably one of the few things it doesn't offer, as molecular biologists feel themselves obliged to rely on the age of fossils to calibrate their 'clocks'.

Cladistics was an attempt to get away from using absolute degree of difference. But now, as before, number of base pairs etc. as degree of difference is supposed to be meaningful, especially with respect to time. Degree of divergence, whether molecular or morphological, may have very little to do with either the age of a group or the time involved in its evolution, and may be determined rather by the evolutionary potential of the group. Under this view, in any given phase of evolution, for example, during a period of rifting, some groups will diverge to species level, others to generic level, while yet others may diverge only cryptically or not at all. This explains why the same biogeographic track is always held by taxa of obviously different rank.

In studies on form, a concept of evolution by 'adaptation' in response to selection pressure can be replaced with one of molecular drive (Craw et al. 1999), morphogenetic series, and pre-adaptation. The synthetic concept of 'adaptive radiation' relies on two of the older concepts, adaptation and the centre of origin.

\section{Rhododendron: adaptive radiation or non-adaptive amalgamation?}

Many tropical botanists have taken a critical view of the significance of 'adaptation'. For example, van Steenis (1958) gave a classic demolition of a textbook orthodoxy 'adaptive features' in mangrove hypocotyls. One of Richards' $(1952,1992)$ main themes in his account of tropical rainforest was a critique of 'adaptationism'. He suggested that any usefulness or 'advantage' in a feature is incidental - a consequence and not a 
cause. Biological structure is the way it is primarily because of prior morphogenetic trends or Darwin's 'laws of growth', 'pruned' only secondarily by natural selection (Grehan and Ainsworth 1985) (and mediated spatially by tectonics). This approach was taken in the analysis of the hypocotyl, above. In another example, red pigments in the young leaves of tropical trees are often assumed to have an adaptive value. However, Richards (1992) cited work giving no support to the view that anthocyanins give a selective advantage to the tree and suggested instead that they may be 'merely byproducts in the synthesis of flavonoid compounds in the young leaves.

In tropical rainforest, rainwater falling on the leaves runs off the acuminate driptips found in so many species there. The classic view is that the drip-tips have evolved in order to facilitate this. However, Richards (1992) cited authors who give a number of reasons why drip-tips have unwettable leaf surfaces, some species have drip-tips on some leaves and not on others, and some plants with long driptips grow in dry environment.

Richards (1992) concluded that 'The crude teleological 'explanations' [of rainforest leaf morphology] of the last century are no longer acceptable', and this is correct; however, Richards continued: 'but there is as yet little to put in their place'. This is probably less correct, as there is much relevant work on morphogenesis. This has not been widely recognised as the primary factor because 'selective pressure' is usually regarded as determining morphology and is invariably cited in the popular media as one of the 'wonders of nature'.

It is hard to imagine that the different forms of scales on the Vireya leaf or the peculiar glands at the base of the leaf in Vaccinium represent any selective advantage. However, they may date back to the origin of the leaf and represent traces of earlier structures largely suppressed during the evolution of the modern leaf from a sterilized inflorescence, rather than something superficial added on later for no apparent reason to an already formed leaf (cf. epiphyllous inflorescences, Watson (1964) on epacrid bracts, etc.).

Rhododendron may be a colossal genus, but is it an 'adaptive radiation', as is often suggested? There is no evidence that it is a radiation from a single point centre of origin, or from a single species (or parent pair). (For a critique of the Darwinian/Hennigian view that clades are descended from a single ancestral species, see Heads 1985b). Despite the claims of both pan-adaptationism and cladistics, probably nothing important in biology happens only once. So-called 'uniquelyderived' characters may only occur in one group, but that is not evidence for their only having evolved once. Neither is there a convincing argument for the great diversity in Erica, Rhododendron or Vaccinium having evolved through adaptation mediated by selection pressure. Rather than New Guinea Rhododendron being the result of an adaptive radiation, it seems more likely to represent the result of amalgamation and juxtaposition, developing during terrane accretion and the formation of modern New Guinea. The next event will be the docking of the $450 \mathrm{~km}$-long New Britain and its distinctive flora with the mainland. Only forms that were pre-adapted survived uplift in New Guinea, others went extinct.

Within Vireya there are no barriers to compatibility (if temperate species in subsect. Pseudovireya are excluded) (Rouse 1985) and reproductive barriers are breached in cultivation. Apomixis does not occur. The Rhododendron keys are based on recombinations of just a few characters, often concerning indument of ovary, style and corolla (presence/absence, lepidote/hairy or both). This recombination is compatible with the group being the direct descendants of a very old, widespread, ancestral hybrid swarm, now largely 'frozen' in place, at least in the wild. 
Many Rhododendron taxa are only slightly differentiated, and this is often taken to be the sign of a young group, and an explosive radiation. As emphasized, there is no reason to assume degree of difference is related either to the age or time of form making. Just as subtly different lithology may indicate the presence of an important tectonic feature, minor differences in, for example, anther glands, may represent the frozen trace of an ancient landscape and its flora. Of course, the age of the biological form-making may have little or no relation to the time it involved.

Vireya seed can be stored for 3 to 5 years (cold, over calcium chloride); light is essential for germination. Rhododendron is a classic weed, dwelling on the ecological and geological margins, these are 'plants of tomorrow', infinitely flexible (within the heliophilic limitation), and most unlikely to ever go extinct in the New Guinea region whatever happens geologically, unlike 'fixed' monotypic or oligotypic groups, even widespread ones like Trimeniaceae (Philipson 1986b).

\section{Conclusions: biogeography and evolution in Ericaceae}

Ericaceae are well known in Europe and North America and they are widespread and conspicuous in the barren wastelands of the far north. Because of this, the family is often portrayed as mainly temperate in distribution and more or less restricted to cold, acid sites. For example, Rhododendron was introduced recently as comprising '850 species native to the northern hemisphere' (Halliday 2001). The subtext here supports the concept of a northern centre of origin (Matthew 1915) and this theme was explicitly and clearly developed in Irving and Hebda's (1993) review. They cited oldest Ericaceae fossils (pollen) at $68 \mathrm{Myr}$ and oldest Rhododendron fossils (leaves) at $50 \mathrm{myr}$, and took these to represent the age of the groups. They also assumed that the location of the oldest Rhododendron fossil (Alaska) represents a centre of origin in North America/Eurasia, from which 'founder populations' migrated into the present main centre, N Burma/Yunnan. They wrote that 'upland terrain seems to be an essential ingredient of rhododendron habitats, and that rhododendrons probably did not originate in [N Burma/Yunnan or Malesia] (where they are now most abundant and most diverse) because these regions did not exist 50 million years ago'. But both these conclusions may well be matters for discussion. Geologists have identified Tibet, most of China, and Burma. Thailand as former parts of Gondwanaland which rifted and separated from that continent (Fig. 6). Amalgamation and accretion of Gondwanaland derived Asian terranes occurred progressively between the Late Devonian and Cretaceous and many sutures are dated as Jurassic, perhaps the most important time for angiosperm evolution.

In fact there is much more diversity in the family than the boreocentric characterisation allows. Ericaceae are highly speciose in the tropics (for example, there are some 777 species in Malesia) and in the southern hemisphere (e.g. in New Guinea, with 161 Rhododendron species), are widespread on the coast even in the tropics, and often grow on limestone or ultramafics in potentially basic sites. This flexibility, within the heliophilous constraint, bestows great potential for survival.

Apart from the early northern hemisphere fossils, which are probably unknown in the southern hemisphere simply due to sampling error in the fossil record (cf. Cracraft 2001 for birds), there is no evidence for a northern centre of origin with subsequent dispersal south. Australian authors, influenced by the abundance of Epacridaceae in Australian and of Ericaceae in New Guinea, have argued against the northern centre of origin idea (Specht and Womersley 1979). Recently, Kron et al. (1999), pointed out that epacrids were sister to the 'vaccinioids' and indicated that this relationship among southern groups was of 'great biogeographic interest' (cf. Willdenow 1798), that is, it contradicts the northern centre of origin. 
In fact, the subfamilies of Ericaceae sens. lat. comprise the classic example in plants of global vicariance among well-known, highly speciose groups. Although there is considerable overlap of the groups in some areas, such as Malesia, the different locations of the main massings are clear and of fundamental significance, as recognized by Hutchinson (1959) and Cullen (1978). The simplest explanation is that there is no point centre of origin and the groups have developed by vicariance in immobilism of an already global ancestral complex. There is no need to invoke any large scale 'migrations' of any of the subfamilies, simply vicariance around the Indian Ocean (Ericoideae-Rhododendroiodeae), Pacific Ocean (Vaccionioideae, epacrids), and Atlantic Oceans (empetrads). The recognition that the SW Cape Roridula is a sister group to Ericaceae gives strong support to the vicariance interpretation, but would not be predicted in the northern centre of origin/dispersal theory.

Why does current biodiversity follow Mesozoic and Tertiary orogens? Possibly because these are zones of accreted terranes. Many of the patterns seen in New Guinea, for example, between craton and accreted terrane biotas, and in dextral offsets, also occur in New Zealand (Heads 1989). Recent ideas on the structure of the Andes are similar to those suggested here for the New Guinea orogen, in particular the Andes are now seen as tectonically more complex than previously thought. J. Flynn (quoted in Moffat 1996) cited the importance of lateral, as well as vertical, movement on faults and emphasized that "The Andes are not homogeneous, biologically or geologically ... There is no such thing as "the Andes". The great diversity of rock types seen in the New Zealand and New Guinea orogens is reflected in an Ericaceae flora which can survive on acid as well as basic, ultrabasic and saline terrain, in welldrained lithophyte and epiphyte communities as well as swampy or periodically inundated sites, and from the mangrove to the high alpine. The ability to tolerate this wide range of heliophilous habitats is probably of long-standing in the family, and it is not surprising that the distributions of taxa in a family characteristic of peaty, sandy regions and sometimes coasts, deltas and swamps should track oil-belts so closely (for example in Aceh and around Makassar Strait). Bituminous sequences and new taxa are often created at the turning points in paleogeographic history (Heads 1989).

Within New Guinea, birds-of-paradise and rhododendrons show many parallels in their ecology and biogeography. The same altitudinal band is most diverse for both, they also show the same disjunctions, breaks in ranges (e.g. the old craton margin), centres of endemism and sites of altitudinal anomalies, all despite very different means of dispersal. None of these are predicted in the chance-dispersal models, but the rejection of 'centres of origin', 'means of dispersal', 'adaptive radiation' and Pleistocene evolution, allows a productive reappraisal of forest ecology and of what Victor Hugo called 'the secret intimacy of bird and tree'.

\section{Acknow ledgments}

Rina Basdeo and Zorah Singh gave much appreciated help with typing. I'm also grateful to two anonymous referees for many useful comments, and to A. Anderberg, George Argent, Hannah Atkins, Gillian Brown, Robin Craw, Jack Dumbacher, B. Eriksen, David Frodin, Rhys Gardner, David Glenny, John Grehan, Robert Hall, Richard Hebda, Jeremy Holloway, K-L. Huynh, W.S. Judd, Kathy Kron, Ian Metcalfe, Bernard Michaux, Lorin Nevling, Jr., Vojtech Novotny, Ted Oliver, Richard Olmstead, Peter Stevens, Silas Sutherland, Wayne Takeuchi, Benito Tan, Jeff Veldkamp, C.M. Weiller and Peter van Welzen, and the late Dr. Ray Forster, Professor Philipson and Professor van Steenis for generous provision of unpublished data and reprints. Special thanks to Alistair Hay and Aubeta Kairo, tupela save-man long ol diwai. 


\section{References}

Abbott, L.D., Silver, E.A., Thompson, P.R., Filewicz, M.V., Schneider, C. and Abdoerrias. (1994) Stratigraphic constraints and timing of arc-continent collision in northern Papua New Guinea. J. Sedimentary Res. B64: 169-183.

Adema, F., Leenhouts, P.W. and van Welzan, P.C. (1994) Sapindaceae. Flora Malesiana I, 11: 419-768.

Airy Shaw, H.K. (1953) Thymelaeaceae-Gonystyloiodeae. Flora Malesiana I, 4: 349-365.

Airy Shaw, H.K. (1973) A Dictionary of the Flowering Plants and Ferns. 8th ed. (Cambridge University Pres: Cambridge)

Airy Shaw, H.K. (1980) The Euphorbiaceae of New Guinea. (Royal Botanic Gardens: Kew)

Anderberg, A. (1992) The circumscription of the Ericales, and their cladistic relationships to other families of 'higher' dicotyledons. Syst. Bot. 17: 660-675.

Anderberg, A.A. (1993. Cladistic relationships and major clades of the Ericales. Pl. Syst. Evol. 184: 207-231.

Anderberg, A.A. (1994) Cladistic classification of Enkianthus with notes on the early diversification of the Ericaceae. Nord. J. Bot. 14: 385-401.

Anderberg, A.A., Rydin, C., and Källersjö, M. (2002) Phylogenetic relationships in the order Ericales s.l.: analysis of molecular data from five genes from the plastid and mitochondrial genomes. Amer. J. Bot. 89: 677-687.

Anderson, J.A.R. (1963) The flora of the peat swamp forests of Sarawak and Brunei, including a catalogue of all recorded species of flowering plants, ferns and fern allies. Gardens Bull. Singapore 20: 131-228.

Archbold, R., Rand, A.L. and Brass L.J. (1942) Results of the Archbold Expeditions. No. 41. Summary of the 1938-1939 New Guinea expedition. Bull. Am. Mus. Nat. Hist. 79: 197-288.

Argent, G.C.G. (1982) Notulae et novitates Muluenses. New taxa and combinations and comments on Ericaceae. Bot. J. Linn. Soc. 85: 217.

Argent, G.C.G. (1985) Vireya Rhododendrons in Borneo. Notes Roy. Bot. Gard. Edinburgh 43: 53-61.

Argent, G.C.G. (1988) Vireya taxonomy in field and laboratory. Proc. Fourth International Rhododendron Conference, October 1988. Wollongong, New South Wales, Australia. (at vireya.net)

Argent, G.C.G. (1992) Plant portrait: Rododendron polyanthemum. Edinb. J. Bot. 49: 1-4.

Argent, G.C.G (1998) Rhododendron madulidii (Ericaceae): a new Philippine species from Palawan. New Plantsman 5: 204-211.

Argent, G.C.G. and Barkman, T. (2000) Two exciting new species of Rhododendron section Vireya (Ericaceae) from Mount Kinabalu, Sabah, New Plantsman 7: 209-219.

Argent, G.C.G. and Dransfield, J. (1989) Rhododendron alborugosum a new species of vireya rhododendron from Borneo. Notes Roy. Bot. Gard. Edinburgh 46: 27-31.

Argent, G.C.G., Lamb, A., and Phillips, A. (1984) New taxa and combinations in vireya rhododendrons from Sabah (Borneo) Notes Roy. Bot. Gard. Edinburgh 42: 113-120.

Argent, G.C.G. and Madulid, D. (1995) Rhododendron sarcodes: a new species from the Philippines. New Plantsman 2: 156-161.

Argent, G.C.G. and Madulid, D. (1998) Rhododendon rousei (Ericaceae): a beautiful new species from the Philippines. New Plantsman 5 (1): 25-31.

Ashton, P.S. (1969) Speciation among tropical forest trees: some deductions in the light of recent evidence. Biol. J. Linn. Soc. 1: 155-196.

Atkins, H., Preston, J. and Cronk, Q.C.B. (2001) A molecular test of Huxley's line: Cyrtandra (Gesneriaceae) in Borneo and the Philippines. Biol. J. Linn. Soc. 72: 143-159.

Atkinson, R., Jong, K., and Argent, G. (1995) Cytotaxonomic observations in tropical Vaccinieae (Ericaceae) Bot. J. Linn. Soc. 117: 135-145.

Avé, W. 1984. Deplanchea Vieill. Pacific Plant Area 4: 152-153.

Avise, J.C. 2000. Phylogeography: The History and Formation of Species. (Harvard University Press: Cambridge)

Axelius, B. (1990) The genus Xanthophytum (Rubiaceae): taxonomy, phylogeny and biogeography. Blumea 34: 425-497.

Bain, J.H.C., Davies, H.L., Hohnen, P.D., Rybuurn, R.J., Smith, I.E., Grainger, R., Tingney, R.J. and Moffat M.R. (1972) Geology of Papua New Guinea 1: 1000000 map. (Bureau of Mineral Resources: Canberra)

Baker, W.J., Coode, M.J.E., Dransfield, J., Dransfield, S., Harley, M.M., Hoffmann, P. and Johns, R.J. (1998) Patterns of distribution of Malesian vascular plants. Pp 1-7 in R. Hall \& J.D. Holloway (eds), Biogeography and Geological Evolution of SE Asia. (Backhuys: Leiden)

Balgooy, M.M.J. van, and Nielsen, I. (1993) Serianthes Benth. Pacific Plant Areas 5: 128-129. 
Baranov, P.A. (1957) Coleorrhiza in Myrtaceae. Phytomorph. 1957: 237-243.

Baranov, P.A., Baranova, E.A. and Polunina, N.N. (1955) An interesting feature of embryogenesis in Eucalyptus. Bot. Z. Akad. Nauk SSSR [Leningrad] (in Russian) 40: 99-102.

Barber, P.H., Palumbi, S.R. Erdmann, M.V.and Kasim Moosa, M. (2000) A marine Wallace's line? Nature 406: 692-693.

Barlow, B.A. (1992) Conspectus of the genus Amyema Tieghem (Loranthaceae) Blumea 36: 293-381.

Barlow, B.A. (1997) Viscaceae. Flora Malesiana I, 13: 403-442.

Beadle, N.C.W. (1981) The vegetation of Australia. (Fischer: Stuttgart)

Beehler, B.M., Pratt, T.K. and Zimmerman, D.A. (1986) Birds of New Guinea. (Princeton University Press: Princeton)

Bentham, G. (1846) Scrophulariaceae. Pp. 320-598 in A. de Candolle (ed.) Prodromus systematis naturalis regni vegetabilis 10. (Paris: Masson)

Bentham. G. and Hooker, J.D. (1862-1898) Genera Plantarum, Vols. 1-3. (London)

Beusekom, C.F. van. (1971) Revision of Meliosma (Sabiaceae) in Malesia. Blumea 19: 499-513.

Beusekom-Osinga, C.F. van (1977) Crypteroniaceae. Flora Malesiana I, 8: 199.

Bhatnagar, S.P., and Johri, B.M. (1983) Embryology of Loranthaceae. Pp. 47-67 in D.M. Calder and P. Bernhardt (eds), The Biology of Mistletoes. (Academic Press: Australia)

Black, M.(1966) Collecting Rhododendron in New Guinea. Roy. Hort. Soc. Rhododendron and Camellia Yearbook 1966. (at vireya.net)

Bleeker, P. (1983) Soils of Papua New Guinea. (CSIRO/ANU: Canberra)

Boer, A.J. de. (1995) Islands and cicadas adrift in the West-Pacific. Biogeographic patterns related to plate tectonics. Tijd. Entom. 138: 169-244.

Boer, A.J., de and Duffels, J.P. (1996a) Historical biogeography of the cicadas of Wallacea, New Guinea and the West Pacific: a geotectonic explanation. Palaeogeog., Palaeoclim., Palaeoecol. 124: 153-177.

Boer, A.J. de and Duffels, J.P. (1996b) Biogeography of Indo-Pacific cicadas east of Wallace's Line. Pp. 297-330 in A. Keast \& S.E. Miller (eds), The origin and evolution of Pacific island biotas, New Guinea to eastern Polynesia: patterns and processes. (SPB Academic Publishing: Amsterdam)

Bowe, L.M., Coat, G., and dePamphilis, C.W. (2000) Phylogeny of seed plants based on all three genomic compartments: extent gymnosperms are monophyletic and Gnetales' closest relatives are conifers. PNAS 97: 4092-4097.

Bremer, B. (1984) The genus Steenisia (Rubiaceae) and its taxonomic position. Nord. J. Bot. 4: 333-345.

Brenan, J.P. (1967) Leguminosae subfam. Caesalpinioideae. Flora of Tropical East Africa. 231 pp.

Briggs, J.C. (1999) Coincident biogeographic patterns: Indo-west Pacific Ocean. Evolution 53: 326-335.

Briggs, J.C. (2000) Centrifugal speciation and centres of origin. J. Biogeog. 27: 1183-1188.

Brookfield, H.C. and Hart, D. (1971) Melanesia: a geographical interpretation of an island world. (Methuen: London)

Brooks, R.R. (1987) Serpentine and its vegetation: a multidisciplinary approach. (Dioscorides Press: Portland)

Brown, G., Bayer, R., Craven, L., Ladiges, P. and Udovicic, F. (2001) Phylogeny of Rhododendron sect. Vireya. Poster presented at Flora Malesiana Symposium, Royal Botanic Gardens Sydney.

Brown, N.E. 1905. Ericaceae, Fl. Capensis 4: 417.

Bugnon, F. (1955) Principaux caractères morphologiques et interprétation ontogènique de hypomérithalles chez les Angiospermes. Bull. Sci. Bourgogne 16: 67-80.

Burtt, B.L. (1970) Studies in the Gesneriaceae of the Old World XXXI: some aspects of functional evolution. Notes Roy. Bot. Gard. Edinburgh 30: 1-10.

Burtt, B.L. (1998) Climatic accommodation and phytogeography of the Gesneriaceae of the Old World. Pp. 1-27 in P. Mathew \& M. Sivadasan (eds) Diversity and Taxonomy of Tropical Flowering Plants. (Mentor: Calicut)

Cain, M.L., Milligan, B.G. and Strand, A.E. (2000) Long-distance seed dispersal in plant populations. Amer. J. Bot. 87: 1217-1227.

Calder, D.M. (1983) Mistletoes in focus: an introduction. Pp. 1-18 in D.M. Calder and P. Bernhardt (eds), The Biology of Mistletoes (Academic Press: Australia)

Camp, W.H. (1947) Distribution patterns in modern plants and the problems of ancient dispersals. Ecol. Monogr. 17: 161-183.

Carlquist, S. (1976) Wood anatomy of Roridulaceae: ecological and phylogenetic implications. Amer. J. Bot. 63: 1003-1008.

Carr, D.J., Jahnke, R. and Carr, S.G.M. 1983. Development of the lignotuber and plant from in Lehmannianae. Aust. J. Bot. 31: 629-643. 
Chaw, S.M., Parkinson, C.L., Cheng, Y., Vincent, T.M. and Palmer, J.D. (2000) Seed plant phylogeny inferred from all three plant genomes: monophyly of extent gymnosperms and origin of Gnetales from conifers. Proc. Nat. Acad. Sci. [USA] 97: 4086-4091.

Cheek, M. and Jebb, M. (2001) Nepenthaceae. Flora Malesiana I, 15: 1-157.

Chin, N., Brown, M. and Heads, M. (1991) The biogeography of Macrocystis (Lessoniaceae) Hydrobiologia 215: 1-11.

Clarke, C. (1997) Nepenthes of Borneo. (Natural History Publications: Kota Kinabalu)

Coetzee, J.A. (1993) African flora since the Terminal Jurassic. Pp.37-61 in P. Goldblatt (ed.) Biological Relationships between Africa and South America. (Yale University Press: New Haven)

Collinson, M.E. and Crane, P.R. (1978) Rhododendron seeds from the Palaeocene of southern England. J. Linn. Soc., Bot. 76:195-205.

Copeland, E.B. (1950) The origin of the Philippine fern flora. Philippine J. Science 79: 1-5.

Corner, E.J.H. (1938) An introduction to the distribution of Ficus. Reinwardtia 4: 15-20.

Corner, E.J.H. (1960) The Malayan flora. Pp. 21-24. Proc. Centen. and Bicentenary Congr. Biology Singapore. University of Malaya Press.

Corner, E.J.H. (1961) A tropical botanist's introduction to Borneo. Sarawak Musuem J. 10: 1-16.

Corner, E.J.H. (1963) Ficus in the Pacific region. Pp. 233-245 in J.L. Gressitt (ed.) Pacific Basin Biogeography: A Symposium. (Bishop Museum: Honolulu)

Corner, E.J.H. (1964) A discussion of the results of the Royal Society Expedition to North Borneo, 1961. Proc. R. Soc. Lond. B 161: 1-91.

Corner, E.J.H. (1966) The Natural History of Palms. (Weidenfeld and Nicolson: London)

Corner, E.J.H. (1978a) The Fresh-water Swamp Forest of South Johore and Singapore. (Botanic Gardens: Singapore)

Corner, E.J.J. (1978b) The inflorescence of Dillenia. Notes Roy. Bot. Gard. Edinburgh 36: 341-353.

Cowling, R.M. (1983) Phytochorology and vegetation history in the south-eastern Cape, South Africa. J. Biogeog. 10: 393-419.

Cracraft, J.L. (2001) Avian evolution, Gondwana biogeography and the K-T mass extinction event. Proc. R. Soc. Lond. B 268: 1-11.

Crane, J. (1975) Fiddler Crabs of the World (Orycopodidae: genus Uca) (Princeton University Press: Princeton)

Craven, L. (1980) A new Rhododendron (Ericaceae) from New Guinea. Notes Roy. Bot. Gard. Edinb. 38: $141-144$.

Craven L. (1996) Proposal to conserve the name Rhododendron lochiae F.Muell. (Ericaceae) with a conserved type. Taxon 45: 135-136.

Craven, L.A. and Dunlop, C.R. (1992) A taxonomic revision of Pachynema (Dilleniaceae) Aust. Syst. Bot. 5: 477-500.

Craven, L. and Withers, R.M. (1996) A second species of Rhododendron from Australia. Edinb. J. Bot. 53: 27-37.

Craw, R.C. (1982) Phylogenetics, area, geology and the biogeography of Croizat: a radical view. Syst. Zool. 31: 304-316.

Craw, R.C. (1985) Classic problems of the southern hemisphere re-examined: panbiogeographic analysis of the New Zealand frog Leiopelma, the ratite birds and Nothofagus. Z. Zool. Syst. Evolut.forsch 23:1-10.

Craw, R.C., Grehan, J.R. and Heads, M.J. (1999) Panbiogeography: tracking the history of life. (Oxford University Press: New York)

Crayn, D.M., Kron, K.A., Gadek, P.A., and Quinn, C.J. (1998) Phylogenetics and evolution of epacrids: a molecular analysis using the plastic gene $r b c \mathrm{~L}$ with a reappraisal of the position of Lebetanthus. Aust. J. Bot. 46: 187-200.

Crayn, D.M. and Quinn, C.J. (2000) The evolution of the $a t p-r b c$ L intergenic spacer in the epacrids (Ericales) and its systematic and evolutionary implications. Molec. Phylogen. Evol. 17: 238-252.

Cribb, P.J. (1983) A revision of Dendrobium sect. Latouria (Orchidaceae) Kew Bull. 38: 229-306.

Croizat, L. (1958) Panbiogeography. 3 vols. (Published by the Author: Caracas)

Croizat, L. (1964) Space, Time, Form: The Biolgical Synthesis. (Published by the Author: Caracas)

Croizat, L. (1965) An introduction to the subgeneric classification of Euphorbia L., with stress on the South African and Malagasy species. Webbia 20: 573-706.

Croizat, L. (1968) Riflessioni sulla biogeografia in generale, e su quella della Malesia in particolare. Atti Ist. Bot. Univ. Lab. Crittogam. [Pavia] ser. 6, 5: 19-190.

Cronquist, A. (1981) An Integrated System of Classification of the Flowering Plants. (Columbia University Press: New York) 
Crowhurst, P.V., Hill, K.C., Foster, D.A., and Bennett, A.P. (1996) Thermochronological and geochemical constraints on the tectonic evolution of northern Papua New Guinea. Pp. 525-537 in R.Hall and D.Blundel (eds), Tectonic evolution in Southeast Asia. Geological Society Special Publication No. 106 (London)

Cullen, J. (1978) Ericaceae. 124-127 in V. Heywood (ed.), Flowering Plants of the World. (Oxford University Press: Oxford)

Darwin, C. (1859) On the Origin of Species. (Murray: London)

Dahlgren, R. (1980) A revised system of classification of the angiosperms. Bot. J. Linn. Soc. 80: 91-124.

Dahlgren, RMT, and Clifford, H.T. (1982) The monocotyledons: a comparative study. (Academic Press: New York)

Danser, B.H. (1928) The Nepenthaceae of the Netherlands Indies. Bull. Jard. Bot. Buitenzorg III. 9: 249-438.

Darlington, P.J., Jr. (1957) Zoogeography: The Geographical Distribution of Animals. (Wiley: New York)

Darwin, C. (1859) On the origin of species. (Murray: London)

De Laubenfels, D.J. (1984) Decussocarpus. Pacific Plant Areas 4: 212-213.

De Laubenfels, D.J. (1988) Coniferales. Flora Malesiana I, 10: 367-442.

Diamond, J.M. (1972) Avifauna of the Eastern Highlands of New Guinea. (Nuttall Ornithological Club: Cambridge, Massachusetts)

Ding Hou (1958) Rhizophoraceae. Flora Malesiana I, 5: 429-493.

Ding Hou (1960) Thymelaeaceae. Flora Malesiana I, 6: 1-48.

Ding Hou (1964) Celastraceae. Flora Malesiana I, 6: 227-288; 389-421.

Dransfield, J. (1978) The growth forms of rainforest palms. Pp. 247-268 in P.B.Tomlinson and M.Zimmermann (eds), Tropical Trees as Living Systems. (Cambridge University Press)

Dransfield, J. (1987) Bicentric distribution in Malesia as exemplified by palms. Pp. 60-72 in T.C. Whitmore (ed.) Biogeographical Evolution of the Malay Archipelago. (Oxford University Press)

Dressler, R.L. (1981) The Orchids: Natural History and Classification. (Harvard University Press: Cambridge)

Dumbacher, J. P. and Fleischer, R. C. (2001) Phylogenetic evidence for colour-pattern convergence in toxic pitohuis: Müllerian mimicry in birds? Proc. Roy. Soc. London: Biology 268: 1971-1976.

Dunson, W.A. (1975) Adaptations of sea snakes. Pp. 1-21 in in W.A.Dunson (ed.), The Biology of Sea Snakes. (University Park Press: Baltimore).

Duyfjes, B.E.E. (1996) Hernandiaceae. Flora Malesiana I, 12: 737-761.

Engler, H.G.A. and Prantl, K.A.E. (1887-1914) Die Natürlichen Pflanzenfamilien. Ed. 1. 23 vols. Leipzig.

Eriksen, B. (1993a) Floral anatomy and morphology in the Polygalaceae. Plant Syst. Evol. 186: 17-32.

Eriksen, B. (1993b) Phylogeny of the Polygalaceae and its taxonomic implications. Plant Syst. Evol. 186: 33-55.

Eskov, K.Y. and Golovatch, S.I. (1986) On the origin of trans-pacific disjunctions. Zoologische Jahrbücher (Systematik) 113: 265-285.

Esser, H.-J. (1999) A partial revision of the Hippomaneae (Euphorbiaceae) in Malesia. Blumea 44: 149-215. (also at http://nhcml.leidenuniv.nl/euphorbs)

Exell, A.W. (1954) Combretaceae. Flora Malesiana I , 4: 533-628.

Flannery, T. (1995) Mammals of New Guinea. 2nd edn. (Reed Books: New South Wales, and Cornell University Press: Ithaca).

Forman, D. (1986) Menispermaceae. Flora Malesiana I, 10: 225-252.

Franklin, D.A. (1962) The Ericaceae in New Zealand (Gaultheria and Pernettya) Trans. Roy. Soc. New Zealand. Botany 1: 155-173.

Frey, J.K. (1993) Modes of peripheral isolate formation and speciation. Syst. Zool. 42: 373-381.

Frodin, D.G. (1998) Notes on Osmoxylon (Araliaceae) II. Flora Malesiana Bull. 12: 153-156.

Fryxell, P.A. 1980. The Natural History of the Cotton Tribe (Malvaceae, Tribe Gossypieae) (Texas A\&M University Press: College Station)

Füchter, R. (2001) Nunataks as glacial refugia during the Last Glacial Maximum? A molecular phylogeographic case study with Draba aizoides L. (Brassicaceae) Bull. Geobotanical Inst. ETH [Zürich] 67: 109-110.

Garcin, M. (1890) Sur Vaccinium. Anns. Soc. Bot Lyon 17: 27.

Gardner, R.O. (2002) The genus Coprosma (Rubiaceae) in New Guinea. Candollea 57: 97-130.

Gentry, A. (1987) Book review of P.B. Tomlinson, 1986, 'The botany of mangroves'. Ann. Missouri Bot. Gard. 74: 460-462.

George, W. (1987) Complex origins. Pp. 119-131 in T.C. Whitmore (ed.) Biogeographical Evolution of the Malay Archipelago. (Oxford University Press) 
Gillett, G.W. (1974) Cyrtandra (Gesneriaceae) in the Bismarck Archipelago and Solomon Islands. Kew Bull. 30: 371-391.

Gillison, A.N. (1970) Structure and floristics of a montane grassland/forest transition, Doma Peaks region, Papua. Blumea 18: 71-86.

Good, R. D'O. (1924) The germination of Hippuris vulgaris L. J. Linn. Soc. Bot. 46: 443-448.

Grehan, J.R. and Ainsworth, R. (1985) Orthogenesis and evolution. Syst. Zool. 34: 174-192.

Grehan, J.R. (2001) Biogeography and evolution of the Galapagos: integration of the biological and geological evidence. Biol. J. Linn. Soc. 74: 267-287.

Grey-Wilson, C. (1989) A revision of Sumatran Impatiens. Kew Bull. 44: 67-106.

Haegens, R.M.A.P. (2000) Taxonomy, phylogeny, and biogeography of Baccaurea, Distichirops, and Nothobaccaurea (Euphorbiaceae). Blumea Suppl. 12: 1-216. (also available at http://nhcml.leidenuniv.nl/euphorbs)

Hahn, W.J. (2002) A molecular phylogenetic study of the Palmae (Arecaceae) based on $a t p \mathrm{~B}, r b c \mathrm{~L}$, and $18 \mathrm{~S}$ nrDNA sequences. Syst. Biol. 51: 92-112.

Hahn, W.J. and Sytsma, K.J. (1999) Molecular systematics and biogeography of the southeast Asian genus Caryota (Palmae). Syst. Bot. 24: 558-580.

Hall, R. (1998) The plate tectonics of Cenozoic SE Asia and the distribution of land and sea. Pp. 99-131 in R. Hall \& J.D. Holloway (eds), Biogeography and Geological Evolution of SE Asia (Backhuys Publishers: Leiden)

Hall, R. (2001) Cenozoic reconstructions of SE Asia and the SW Pacific changing patterns of land and sea. In I. Metcalfe (ed.), Faunal and Floral Migrations and Evolution of SE Asia and Australia. (Balkema: Rotterdam)

Hallé, F., Oldeman, R.A.A. and Tomlinson, P.B. (1978) Tropical Trees and Forests: An Architectural analysis. (Springer: Berlin)

Halliday, P. (2001) The Illustrated Rhododendron: Their Classification Portrayed Through the Artwork of Curtis's Botanicl Magazine. (Timber Press: Portland, Oregon)

Hansen, B. (1974) Balanophoraceae. Flora Malesiana I, 7: 783-811.

Hartley, T.G. (2001) Morphology and biogeography in Australasian-Malesian Rutaceae. Malayan Nature J. 55: 197-219.

Hay, A. (1996) The genus Schismatoglottis Zoll. \& Moritzi (Araceae: Schismatoglossideae) in Peninsular Malaysia and Singapore. Sandakania 7: 1-30.

Hay, A. (1998) The genus Alocasia (Araceae-Colocasieae) in West Malesia and Sulawesi. Gardens Bull. Singapore 50: 221-334.

Hay, A. Bogner, J. and Boyce, P.C. (1994) Nephthytis Schott (Araceae) in Borneo: a new species and new generic record for Malesia. Novon 4: 365-368.

Hay, A. and Wise, R. (1991) The genus Alocasia (Araceae) in Australasia. Blumea 35: 499-545.

Heads, M. (1983) Review of 'Pacific plate biogeography, with special reference to shorefishes' by V. Springer. Journal of Biogeography 10: 543-548.

Heads, M. (1984) Principia Botanica: Croizat's contribution to botany. Tuatara [Wellington] 27: 26-48.

Heads, M. (1985a) Biogeographic analysis of Nothofagus (Fagaceae). Taxon 34: 474-492.

Heads, M. (1985b) On the nature of ancestors. Syst. Zool. 34: 205-215.

Heads, M. (1989) Integrating earth and life sciences in New Zealand natural history: the parallel arcs model. New Zealand J. Zool. 16: 549-586.

Heads, M. (1990) A taxonomic revision of Kelleria and Drapetes (Thymelaeaceae). Austr. Syst. Bot. 3: 595-652.

Heads, M. (1994a) Morphology, architecture and taxonomy in the Hebe complex (Scrophulariaceae). Bull. Mus. Nat. d'Hist. Nat. Paris 4e sér. 16, sect. B, Adansonia 163-191.

Heads, M. (1994b) A biogeographic review of Parahebe (Scrophulariaceae). Bot. J. Linn. Soc. 115: 65-89.

Heads, M. (1996) Biogeography, evolution and taxonomy in the Pacific genus Coprosma (Rubiaceae). Candollea 51: 381-405.

Heads, M. (1998a) Biodiversity in the New Zealand divaricating tree daisies: Olearia sect. nov. (Compositae: Astereae). Bot. J. Linn. Soc. 127: 239-285.

Heads, M. (1998b) Biogeographic disjunction along the Alpine fault, New Zealand. Biol. J. Linn. Soc. 63: $161-176$.

Heads, M. (1999) Vicariance biogeography and terrane tectonics in the South Pacific: an analysis of the genus Abrotanella (Compositae), with a new species from New Zealand. Biol. J. Linn. Soc. 67: 391-432.

Heads, M. (2001a) Regional patterns of biodiversity in New Guinea plants. Bot. J. Linn. Soc. 136: 67-73.

Heads, M. (2001b) Birds of paradise, biogeography and ecology in New Guinea: a review. J. Biogeog. 28: 893-927. 
Heads, M. (2001c) Birds of paradise and bowerbirds: regional levels of biodiversity in New Guinea and correlations with terrane tectonics. J. Zool. [London] 255: 331-340.

Heads, M. (2002a) Birds of paradise, vicariance biogeography and terrane tectonics in New Guinea. J. Biogeog. 29: 261-283.

Heads, M. (2002b) Regional patterns of biodiversity in New Guinea animals. J. Biogeog. 29: 285-294.

Heads, M. and Patrick, B.H. In press. Biogeography of southern New Zealand. In: Natural History of Southern New Zealand. (Otago University Press: Dunedin)

Heel, W.A. van. (1973) Flowers and fruit in Flacourtiaceae I. Scaphocalyx spathacea Ridl. Blumea 21: $259-279$

Hennig, W. (1966) Phylogenetic Systematics. (University of Illinois Press: Urbana)

Heraty, J.M. (1995) Classification and evolution of the Oraseminae in the Old World, including revisions of two closely related genera of Eucharitinae (Hymenoptera: Eucharitidae). Roy. Ontario Mus. Life Sci. Contr. 157.

Hileman, L.C., Vasey, M.C., Parker, V.T.T. (2001) Phylogeny and biogeography of the Arbutoideae (Ericaceae): implications for the Madrean-Tethyan Hypothesis. Syst. Bot. 26: 131-143.

Hill, A.W. (1916) Studies in seed germination. The genus Marah (Megarrhiza), Cucurbitaceae. Anns. Bot. 30: 215-222.

Holloway, J.D. (1998) Geological signal and dispersal noise in two contrasting insect groups in the Indo-Australian tropics: R-mode analysis of pattern in Lepidoptera and cicadas. Pp. 291-314 in R. Hall \& J.D. Holloway (eds), Biogeography and Geological Evolution of SE Asia. (Backhuys Publishers: Amsterdam)

Holloway, J.D. and Hall, R. (1998) SE Asian geology and biogeography. Pp. 1-23 in R. Hall \& J.D. Holloway (eds), Biogeography and Geological Evolution of SE Asia. (Backhuys Publishers: Amsterdam)

Holmes, D. and Phillips, K. (1996) The Birds of Sulawesi. (Oxford University Press: Kuala Lumpur) Holttum, R.E. (1963) Cyatheaceae. Flora Malesiana II, 1: 65-176.

Holttum, R.E. (1964) Distribution of some of the more primitive ferns of Kinabalu. Proc. Roy. Soc. B. 161: 38-48.

Holttum, R.E. (1981) Thelypteridaceae. Flora Malesiana II, 1: 331-560.

Holttum, R.E. (1991) Tectaria group. Flora Malesiana II, 2: 1-101.

Hooker, J.D. (1860) Botany of the Antarctic voyage ... III. Flora Tasmaniae. (Reeve: London)

Hooren, A.M.N.van, and Nooteboom, H.P. (1988) Linaceae. Flora Malesiana I, 10: 607-613.

Hooren, A.M.N. van, and Nooteboom, H.P. (1988) Ctenolophonaceae. Flora Malesiana I, 10: 629-634.

Hoot, S.B. and Douglas, A.W. (1998) Phylogeny of the Proteaceae based on atpB and atpB-rbcL intergenic spacer region sequences. Aust. Syst. Bot. 11: 301-320.

Hovenkamp, P. (1998) Polypodiaceae. Flora Malesiana II, 3: 1-234.

Howard, R. and Moore, A. (1984) A Complete Checklist of the Birds of the World (Revised edn) (Macmillan: London)

Huber, H. (1993) Aristolochiaceae. Pp. 129-137 in K. Kubitzki, J.C. Rohwer, and V. Bittrich (eds), The families and genera of vascular plants, Vol. II. (Springer-Verlag, Berlin)

Hutchinson, J. (1959) The Families of Flowering Plants. 2nd edn. (Oxford University Press: London)

Hutchison, C.S. (1996) The 'Rajang accretonary prism' and 'Lupar Line' problem of Borneo. Pp. 247-261 in R.Hall and D.Blundell (eds), Tectonic evolution of southeast Asia. Geological Society Special Publication No. 106 (London)

Huxley, C.R. and Jebb, M.H.P. (1991) The new genus Anthorrhiza (Rubiaceae) Blumea 36: 20-35.

Huynh, K-L. (1999) The genus Freycinetia (Pandanaceae) in New Guinea (part 2). Bot. Jahrb. Syst. 121: 149-186.

Huynh, K-L. (2000) The genus Freycinetia (Pandanaceae) in New Guinea (part 3). Candollea 55: 283-306.

Irving, E. and Hebda, R. (1993) Concerning the origin and distribution of Rhododendrons. J. Amer. Rhododendron Soc. 47: 139-146, 157-162.

Jacobs, M. (1954) Malpighiaceae. Flora Malesiana I, 5: 125-145.

Jansen, M.E. and Ridsdale, C.E. (1983) A revision of the genus Dolicholobium (Rubiaceae). Blumea 29: 251-311.

Johns, R.J. (1972) Vegetation. Pp. 1163-1170 in P. Ryan (ed.), Encyclopedia of Papua New Guinea. (Port Moresby)

Johns R.J. and Argent, G. (1995) Rhododendron culminicolum var. angiense. (Ericaceae). Curtis's Bot. Mag. 12: 77-85.

Johns, R.J. and Hay, A. (1981) A Student's Guide to the Monocotyledons of Papua New Guinea. Part 1. (Papua New Guinea Forestry College: Bulolo) 
Judd, W.S. and Kron, K.A. (1993) Circumscription of Ericaceae (Ericales) as determined by preliminary cladistic analyses based on morphological, anatomical and embryological features. Brittonia 45: 99-114.

Juniper, B.E., Robins, R.J. and Joel, D.M. (1989) The Carnivorous Plants. (Academic Press: London)

Kalkman, C. (1979) Dispersal and distribution of Malesian angiosperms. Pp. 135-141 in K. Larsen and L. Holm-Nielsen (eds), Tropical Botany. (Academic Press: London)

Kalkman, C. (1993) Rosaceae. Flora Malesiana I, 11: 227-351.

Kalkman, C. and Vink, W. (1970) Botanical exploration in the Doma Peaks region, New Guinea. Blumea 18: 87-135.

Kanis, A. (1971) Ochnaceae. Flora Malesiana 1, 7: 97-119.

Kårehed, J. (2001) Multiple origin of the tropical forest tree family Icacinaceae. Amer. J. Bot. 88: 2259-2274.

Kerr, L.R. (1925) The lignotubers of eucalypt seedlings. Proc. Roy Soc. Victoria 37: 79-96.

Kiew, R. (1984) The genus Myxoporum L., (Oleaceae). Blumea 29: 499-512.

Kinsman, D.J.J. (1998) Rhododendrons in Yunnan, China: $\mathrm{pH}$ of associated soils. New Plantsman 5: 32-38.

Koechlin, J. (1967) Germination et développement des plantules des Hydrostachyacées. Adansonia ser. 2, 7: 525-534.

Kores, P. (1978) A new species of Rhododendron from New Guinea (Ericaceae). Blumea 24: 181-183.

Kores, P. (1984) Notes on the genus Rhododendron (Ericaceae) in Papua New Guinea. Blumea 30: 45-49.

Kramer, K.U. (1971) Lindsaea group. Flora Malesiana II, 1: 177-254.

Kras`an, F. (1883) Über die Bedeutung der gegenwärtigen Vertikalzonen der Pflanzen für die Kenntniss von den allmählichen Niveauerveränderungen der Erdoberfläche. Engl. Bot. Jahrb. 4: 266-307.

Kron, K.A. (1996) Phylogenetic relationships of Empetraceae, Epacridaceae, and Ericaceae: evidence from nuclear ribosomal $18 \mathrm{~S}$ sequence data. Ann. Bot. 77: 293-303.

Kron, K.A. (1997) Phylogenetic relationships of Rhododendroideae (Ericaceae). Amer. J. Bot. 84: 973-980.

Kron, K.A. Fuller, R., Crayn, D.M., Gadek, P.A. and Quinn, C.J. (1999) Phylogenetic relationships of epacrids and vaccinioids (Ericaceae s.l.) based on matK sequence data. Pl. Syst. Evol. 218: 55-65.

Kron, K.A. and Judd, W.S. (1990) Phylogenetic relationships within the Rhodoreae (Ericaceae) with specific comments on the placement of Ledum. Syst. Bot. 15: 57-68.

Kron, K.A. Judd, W.S. and Crayn, D.M. (1999) Phylogenetic analyses of Andromedeae (Ericaceae subfam. Vaccinioideae). Amer. J. Bot. 86: 1290-1300.

Kurashige, Y., J.-I. Etoh, T. Handa, K. Takayanagi \& T. Yukawa (2001) Sectional relationships in the genus Rhododendron (Ericaceae): evidence from matK and trnK intron sequences. Pl. Syst. Evol. 228: 1-14.

Lam, H.J. (1929) Fragmenta papuana VI. Boven de boschgrens: de Doormantop en zijn begroeiing. Natuurk. Tijdschr. Ned. Indië 89: 67-140.

Lam, H.J. (1930) Het genetisch-plantengeografisch enderzoek van den Indischen Archipel en Wegener's verschuivingstheorie. K. Nederlands Aardrijkskundig Genootschap Tijdschrift S.2 47: 553-581.

Landrum, L.R. and Stevenson, D. 1986. Variability of embryos in Subtribe Myrtinae (Myrtaceae). Syst. Bot. 11: 155-162.

Lattke, J.E. In press. Trans-pacific Ponerine ants. J. Nat. Hist.

Leenhouts, P.W., in collaboration with Kalkman, C. and Lam, H.J. (1956) Burseraceae. Flora Malesiana I, 5: 209-296.

Leenhouts, P.W. (1962) Loganiaceae. Flora Malesiana I, 6: 293-387.

Leenhouts, P.W. (1973) A revision of Crossonephelis (Sapindaceae). Blumea 21: 91-103.

Leiser, A.T. (1968) A mucilaginous root sheath in Ericaceae. Amer. J. Bot. 55: 391-398.

Léonard, J. (1957) Genera des Cynometreae et des Amherstieae africaines (LeguminosaeCaesalpinioideae). Essai de blastogénie appliquée à la systématique. Mém. Acad. Roy. Belg. Cl. Scs. 8, 30: 1-314.

Levi, H.W. (1982) The spider genera Psechrus and Fecenia (Araneae: Psechridae). Pacifc Insects 24: 114-138.

Lloyd, F.E. (1976) The Carnivorous Plants. (Dover: New York)

Löffler, E. (1977) Geomorphology of Papua New Guinea. (CSIRO/ Australian National University Press: Canberra)

Lubbock, J. (1892) On Seedlings. (Murray: London)

Lubbock, J. (1907) A Contribution to Our Knowledge of Seedlings. Popular Edition. (Kegan Paul: London)

Luteyn, J.L. (1989) Neotropical montane Ericaceae. Pp. 301-305 in L.B. Holm-Nielsen, I.C. Nielsen and H. Balslev (eds), Tropical Forests: Botanical Dynamics, Speciation and Diversity. (Academic Press: London)

Luteyn, J.L. (2002) Diversity, adaptaton, and endemism in Neotropical Ericaceae: biogeographical patterns in the Vaccinieae. Bot. Rev. 68: 55-87. 
Mabberley, D.J. (1979) The species of Chisocheton (Meliacae). Bull. Br. Mus. (Nat. Hist.) Botany 6: 301-386. Mabberley, D.J. (1981) Revolutionary Botany: 'Thalassiophyta' and other essays of A.H. Church. (Clarendon Press: Oxford)

Mackerras, I.M. (1971) Papuan-Melanesian Diachlorini (Diptera: Tabanidae). Pacific Insects 13: 405-427.

MacKinnon, K., Hatta, G., Halim, H. and Mangalik, A. (1996) The Ecology of Kalimantan. (Periplus Edns: Hong Kong)

Malod, J.A., and Kemal, B.M. (1996) The Sumatra margin: oblique subduction and lateral displacement of the accretionary prism. Pp. 19-28 in Hall, R. and Blundell, D. (eds), Tectonic Evolution of Southeast Asia. Geological Society Special Publication No. 106 (London)

Mark, A.F. and Adams, N.M. (1979) New Zealand Alpine Plants. (Reed: Wellington)

Markgraf, F. (1977) Florae Malesianae praecursores LV Apocynaceae IV. Alyxia. Blumea 23: 377-414.

Mathis, W.N., and Zatwarnicki, T. (2002) A phylogenetic study of the tribe Dryxini Zatwarnicki (Diptera: Ephydridae). Smithson. Contr. Zool. 617: 1-101.

Matthew, W.D. (1915) Climate and Evolution. (New York)

Mayr, E. (1942) Systematics and the Origin of Species. (Columbia University Press: New York)

Meijden, R. van der. (1988) Polygalaceae. Flora Malesiana I, 10: 455-493.

Meijer, W. 1974. The montane forest zone on Mount Kinabalu Borneo - near the National Park Headquarters. Ann. Report Trustees Sabah National Parks 1974: 12-18.

Mepham, R.H. and Mepham, J.S. (1985) The flora of tidal forests - a rationalisation of the use of the term ‘mangrove'. S. Afr. J. Bot. 51: 77-99.

Metcalfe, I. (1998) Paleozoic and Mesozoic geological evolution of the SE Asian region: multidisciplinary constraints and implications for biogeography. Pp. 25-41 in R. Hall and J.D. Holloway (eds), Biogeography and Geological Evolution of SE Asia (Backhuys: Leiden)

Metcalfe, I. (1999) Gondwana dispersal and Asian accretion: an overview. Pp. 9-28 in I. Metcalfe (ed.), Gondwana Dispersal and Asian Accretion. (IGCP Final Results Volume) (Balkema: Rotterdam)

Metcalfe, I. (2001) Palaeozoic and Mesozoic tectonic evolution and biogeography of SE AsiaAustralasia. Pp. 15-34 in I. Metcalfe, J.M.B. Smith, M. Morwood and I. Davidson (eds), Faunal and Floral Migrations and Evolution in SE Asia-Australasia. (Balkema: Lisse)

Michaux, B. (1994) Land movements and animal distributions in east Wallacea (eastern Indonesia, Papua New Guinea and Melanesia). Palaeogeog., Palaeoclim., Palaeoecol. 112: 323-343.

Michaux, B. (1995) Distributional patterns in west Wallacea and their relationship to regional tectonic structure. Sarawak Mus. J. 163-179.

Middleton, D.J. (1991) Infrageneric classification of the genus Gaultheria L. (Ericaceae). Bot. J. Linn. Soc. 106: 229-258.

Middleton, D.J. (1997) A revision of Parsonsia R. Br. (Apocynaceae) in Malesia. Blumea 42: 191-248.

Minton, S.A. (1975) Geographic distribution of sea snakes. Pp. 21-31 in W.A.Dunson (ed.), The Biology of Sea Snakes. (University Park Press: Baltimore)

Moffat, A.S. (1996) Biogeographers take a new view of the ancient Andes. Science 272: 1420-1421.

Molinas, M.L. and Verdaguer, D. (1993a) Lignotuber ontogeny in the cork-oak (Quercus suber: Fagaceae) I. Late embryo. Amer. J. Bot. 80: 172-181.

Molinas, M.L. and Verdaguer, D. (1993b) Lignotuber ontogeny in the cork-oak (Quercus suber: Fagaceae) II. Germination and young seedling. Amer. J. Bot. 80: 182-191.

Mooi, R.D. (1995) Revision, phylogeny, and discussion of biology and biogeography of the fish genus Plesiops (Percioformes: Plesiopidae) Roy. Ontario Mus. Life Sci. Contr. 159.

Morley, C.K. (2002) A tectonic model for the Tertiary evolution of strike-slip faults and rift basins in SE Asia. Tectonophysics 347: 189-215.

Nevling, L.I.Jr. (1961) A revision of the Asiatic genus Enkleia (Thymelaeaceae) J. Arnold. Arbor. 42: 373-396.

Ng, F.S.P. (1978) Strategies of establishment in Malaysian forest trees. Pp. 129-162 in Tomlinson, P.B. \& Zimmerman, M. (eds) Tropical trees as living systems. (Cambridge University Press)

Nielsen, I., Baretta-Kuipers, T. \& Guinet, Ph. (1985) The genus Archidendron F. v. M. - Opera Bot. 76: 1-120.

Nixon, K.C. and Crepet, W.L. (1993) Late Cretaceous fossil flowers of Ericalean affinity. Amer. J. Bot. 80: 616-623.

Nooteboom, H.P. (1964) Simaroubaceae. Flora Malesiana I, 6: 193-226.

Noshiro, S. and Suzuki, M. (2001) Ontogenetic wood anatomy of tree and subtree species of Nepalese Rhododendron (Ericaceae) and characterization of shrub species. Amer. J. Bot. 88: 560-569.

Novotny, V. and Missa O. (2000) Local versus regional species richness in tropical insects: one lowland site compared with the island of New Guinea. Ecol. Entom. 25: 445-451. 
Ojeda, F. (1998) Biogeography of seeder and resprouter Erica species in the Cape Floristic Region - where are the resprouters? Biol. J. Linn. Soc. 63: 331-347.

Oliver, E.G.H. (1989) The Ericoideae and the southern African heathers. Bot. J. Linn. Soc. 101: 319-327.

Oliver, E.G.H. (1991) The Ericoideae (Ericaceae) - a review. Contrib. Bolus Herbarium 13: 158-208.

Oliver, E.G.H. (2000) Systematics of Ericeae (Ericaceae: Ericoideae), species with indehiscent and partially dehiscent fruits. Contrib. Bolus Herbarium 19: 1-483.

Oliver, E.G.H. Linder, H.P. and Rourke, J.P. (1983) Geographical distribution of present-day Cape taxa and their phytogeographical significance. Bothalia 14: 427-440.

Oliver, W.R.B. (1928) A revision of the genus Dracophyllum. Trans New Zealand Inst. 59: 678-714.

Olmstead, R.G., Ki-Joong Kim, Jansen, R.K., and Wagstaff, S.J. (2000) The phylogeny of the Asteridae sensu lato based on chloroplast $n d h \mathrm{~F}$ gene sequences. Molec. Phylogen. Evol. 16: 96-112.

Paijmans, K. (1976) New Guinea Vegetation. (CSIRO/ANU: Canberra)

Pannell, C.M. (1992) A taxonomic monograph of the genus Aglaia Lour. (Meliaceae). Kew Bulletin Additional Series 16.

Parenti, L. (1991) Ocean basins and the biogeography of freshwater fishes. Aust. Syst. Bot. 4: 137-149.

Parris, B.S. (1983) A taxonomic revision of the genus Grammitis Swartz (Grammitidaceae: Filicales) in New Guinea. Blumea. 29: 13-222.

Parris, B.S. (1996) Measurements of pteridophyte species diversity in Malesia and New Zealand. Pp 43-51 in J.M. Camus, M. Gibby \& R.J. Johns (eds), Pteridology in Perspective. (Royal Botanic Gardens: Kew)

Paterson, B. (1960) Revision of the genus Acrotriche R. Br. (Epacridaceae) Proc. Linn. Soc. N.S.W. 85: 75-93.

Paterson, B.R. (1961) Studies of floral morphology in the Epacridaceae. Bot. Gaz. 259-279)

Peltier, M. (1970) Singularités de la graine et de la plantule chez Phylloxylon ensifolium H. Baill. (Papilionacées). Adansonia ser. 2, 10: 533-5.

Percival, M. and Womersley, J.S. (1975) Floristics and Ecology of the Mangrove Vegetation of Papua New Guinea. (Division of Botany: Lae)

Perrier de la Bâthie, H. (1927) Les Philippia de Madagascar. Arch. Botanique [Caen] 1(2): 1-66.

Perry, P. (1994) A revision of the genus Eriospermum (Eriospermaceae). Contr. Bolus Herb. 17: 1-320.

Philipson, W.R. (1966) Introduction to session on the development of the shoot apex. Pp.13-19 in Anon. (ed.) Differentiation of Apical Meristems and Some Problems of Ecological Regulation of Development of Plants. (Academia: Praha)

Philipson, W.R. (1970) Floristics of Rarotonga. Pp. 49-54. In The Cook Bicentenary Expedition in the South-west Pacific. (Royal Society of New Zealand: Wellington)

Philipson, W.R. (1974) Ovular morphology and the major classification of the dicotyledons. Bot. J. Linn. Soc. 68: 89-108.

Philipson, W.R. (1975) Evolutionary lines within the dicotyledons. New Zealand J. Bot. 13: 73-91.

Philipson, W.R. (1977) Ovular morphology and the classification of dicotyledons. Plant Syst. Evol. Suppl. 1: 123-140.

Philipson, W.R. (1979) Araliaceae - I. Flora Malesiana I, 9: 1-105.

Philipson, W.R. (1980) Kairoa, a new genus of Monimiaceae from Papua New Guinea. Blumea 26: 367-372.

Philipson, W.R. (1986a) Monimiaceae. Flora Malesiana I, 10: 255-326.

Philipson, W.R. (1986b) Trimeniaceae. Flora Malesiana I, 10: 327-333.

Philipson, W.R. and Stone, B.C. (1980) The systematic position of Aralidium Miq. A multidisciplinary study. 1. Introduction and floral and general anatomy. Taxon 29: 391-416.

Pigram, C.J. and Davies, P.J. (1987) Terranes and the accretion history of the New Guinea orogen. BMR J. Austral. Geol. Geophys. 10: 193-212.

Pichi-Sermolli, R. and Heiniger, H. (1952) Adumbratio Florae Aethiopicae, II. Ericaceae. Webbia 9: 9-48.

Platnick, N. (1981) Progression rule or beyond rules in biogeography. In Nelson, G. and D. Rosen (eds) Vicariance Biogeography: A Critique. (Columbia University Press: New York)

Polhemus, D.A. (1996) Island arcs, and their influence on Indo-Pacific biogeography. Pp. 51-66 in A. Keast and S.E. Miller (eds), The Origin and Evolution of Pacific Island Biotas, New Guinea to Eastern Polynesia: patterns and processes. (SPB Academic Publishing: Amsterdam)

Polhemus, D.A. and Polhemus, J.T. (1998) Assembling New Guinea: 40 million years of island arc accretion as indicated by the distributions of aquatic Heteroptera (Insecta). Pp. 327-340 in R. Hall \& J.D. Holloway (eds), Biogeography and Geological Evolution of SE Asia. (Backhuys: Leiden)

Prance, G.T. (1989) Chrysobalanaceae. Flora Malesiana I, 10: 635-677. 
Pubellier, M., Quebral, R., Aurelio, M., and Rangin, C. (1996) Docking and post-docking escape tectonics in the southern Philippines. Pp. 511-523 in R.Hall and D.Blundell (eds), Tectonic Evolution in Southeast Asia. Geological Society Special Publication No. 106 (London)

Puff, C. (1986) A biosystematic study of the African and Madagascan Rubiaceae - Anthospermeae. Plant Syst. Evol. Suppl. 3.

Purseglove, J.W. (1988) Tropical Crops: Dicotyledons. (Longman: Singapore)

Rand, A.L., and Gilliard, E.T. (1967) Handbook of New Guinea Birds. (Weidenfeld and Nicolson: London)

Raynal, J. (1976) Une Lobéliacée Polynésienne nouvelle. Adansonia sér. 2, 16: 379-382

Retallack, G. and Dilcher, D. (1981) A coastal hypothesis for the rise to dominance of flowering plants. Pp. 27-77 in K. Niklas (ed.) Paleobotany, Paleoecology and Evolution. Vol. 2 (Praeger: New York)

Richards, P.W., Walsh, R.P.D., Baillie, I.C., and Grieg-Smith, P. (1992, The Tropical Rain Forest: An Ecological Study. 2nd Edn. (Cambridge Univ. Press: Cambridge)

Ridder-Numan, J. (1998) Historical biogeography of Spatholobus (Leguminosae). Pp. 259-277 in R. Hall \& J.D. Holloway (eds), Biogeography and Geological Evolution of SE Asia (Backhuys Publishers, Leiden)

Ridley, H. (1930) The Dispersal of Plants Throughout the World. (Ashford: Kent)

Riedel, A. (2001) Revision of the Euops quadrifasciculatus-group (Coleoptera: Curculionoidea: Attelabidae) from the Australian region, with a discussion of shifts between Nothofagus and Eucalyptus host plants. Invert. Taxon. 15: 551-587.

Robson, N.K.B. (1981) Studies in the genus Hypericum L. (Guttiferae) 2. Characters of the genus. Bull. Br. Mus. Nat. Hist. (Bot) 8: 55-226.

Rodd, A.N. (1998) Revision of Livistona (Arecaceae) in Australia. Telopea 8: 49-153.

Rouse, J.L. (1985) The propagation of Rhododendron section Vireya from seed. Notes Roy. Bot. Gard. Edinb. 43 (1) (at vireya.net)

Royen, P. van, and Steenis, C.G.G.J. van. (1952) Eriandra, a new genus of Polygalaceae from New Guinea. J. Arnold Arbor. 33: 91-95.

Royen, P. van and Kores, P. (1982) Ericaceae. Vol. 3. Pp. 1485-1926 in P. van Royen (ed.), Alpine Flora of New Guinea. 4 vols. (Cramer: Vaduz)

Ruthsatz, B. (1978) Las plantas en cojín de los semi-desiertos andinos del Noroeste Argentina. Darwiniana 21: 494-539.

Salisbury, E.J. (1967) On the reproduction and biology of Elatine hexandra (Lapierre) DC. (Elatinaceae): a typical species of exposed mud. Kew Bull. 21: 139-149.

Sallé, G. (1983) Germination and establishment of Viscum album L. Pp. 145-159 in D.M. Calder and P. Bernhardt (eds), The Biology of Mistletoes. (Academic Press: Australia)

Sastre-De Jesús, I. (1987) Revision of the Cyrtopodaceae and transfer of Cyrtopodendron to the Pterobryaceae. Mem. New York Bot. Gard. 45: 709-721.

Savolainen, V., Fay, M.F., Albach, D.C., Backlund, A., van der Bank, M., Cameron, K.M., Johnson, S.A., Lledó, M.D., Pintaud, J.C., Powell, M., Shehan, M.C., Soltis, D.E., Soltis, P.S., Weston, P., Whitten, W.M., Wurdack, K.J. and Chase, M.W. (2000) Phylogeny of the eudicots: a nearly complete familial analysis based on rbcL gene sequences. Kew Bull. 55:257-309.

Schlechter R. (1982) The Orchidaceae of German New Guinea. (Translation of the 1911-1914 German edn) (Australian Orchid Foundation: Melbourne)

Schnell, R. (1970) Introduction à la Phytogéographie des Pays Tropicaux. 2 vols. (Gauthiers-Villars: Paris)

Scholz, U. (1981) Monographie der Gattung Oplismenus (Gramineae). Phanerogamarum Monographiae 13.

Schouten, Y. and Veldkamp, J.F. (1985) A revision of Anthoxanthum including Hierochloe (Gramineae) in Malesia and Thailand. Blumea 30: 319-351.

Schumann, D., Kirsten, G. and Oliver, E.G.H. (1992) Ericas of South Africa. (Fernwood: Vlaeberg)

Schwendt, E. (1907) Zur Kenntnis der extrafloralen Nektarien. Bot. Zentralbl. 22: 245-286.

Scott, A.J. (1979) A revision of Xanthomyrtus (Myrtaceae) Kew Bull. 33: 461-484.

Seberg, O. (1988) Taxonomy, phylogeny, and biogeography of the genus Oreobolus R.Br. (Cyperaceae), with comments on the biogeography of the South Pacific continents. Bot. J. Linn. Soc. 96: 119-195.

Seveke, J. (1955) Nijmegen: Scenes of Life in Holland's Imperial City. (Municipal Authorities: Nijmegen)

Sevilla, S., and Welzen, P.C. van. (2001) Revision and phylogeny of Agrostistachys and Chondrostylis (Euphorbiaceae). Blumea 46: 71-97. (also at http://nhcml.leidenuniv.nl/euphorbs)

Sibley, C.G. and Ahlquist, J.E. (1985) The phylogeny and classification of the Australo-Papuan passerine birds. Emu 85: 1-14.

Skottsberg, C. (1940) The flora of the Hawaiian Islands and the history of the Pacific basin. Sixth Pacific Science Congress 4: 685-707. 
Sleumer, H. (1941) Vaccinioideen-Studien. Bot. Jahrb. 71: 375-510.

Sleumer, H. (1942) Icacinaceae. Nat. Pflazenfam. ed. 2. 20b: 322-396.

Sleumer, H. (1954) Flacourtiaceae. Flora Malesiana I, 5: 1-106.

Sleumer, H. (1963) Florae Malesianae praecursores XXXVII. Materials towards the knowledge of the Epacridaceae mainly in Asia, Malaysia, and the Pacific. Blumea 12: 145-171.

Sleumer, H. (1964) Epacridaceae. Flora Malesiana I, 6: 422-444.

Sleumer, H. (1966) Ericaceae. Flora Malesiana I, 469-668.

Sleumer, H. (1967) Ericaceae (cont.) Flora Malesiana I, 6: 669-914.

Sleumer, H. (1971a) Icacinaceae. Flora Malesiana I, 7: 1-87.

Sleumer, H. (1971b) Clethraceae. Flora Malesiana I, 7: 139-150.

Sleumer, H. (1973) New species and noteworthy records of Rhododendron in Malesia Ericaceae) Blumea 21: 357-376.

Sleumer, H. (1986) A revision of the genus Rapanea Aubl. (Myrsinaceae) in New Guinea. Blumea 31: 245-269.

Slooten, D.R. van. (1925) The Flacourtiaceae of the Dutch East Indies. Bull. Jard. Bot. Buitenzorg III, 7: 291-421.

Smith, A.C. (1946) Studies of South American plants, XI: Noteworthy species of Hippocrateaceae and Vacciniaceae. J. Arnold Arbor. 27: 86-120.

Smith, M. (1926) Monograph of the Sea-snakes (Hydrophiidae) (British Museum (Natural History): London)

Smith, W. (1909) The anatomy of some Sapotaceous seedlings. Trans. Linn. Soc. Ser. 2 Botany 7: 189-200. Pls. 25, 26.

Soepadmo, E. (1972) Fagaceae. Flora Malesiana 1, 7: 265-403.

Soepadmo, E. (1977) Ulmaceae. Flora Malesiana I, 8: 31-76.

Solem, A. (1958) Biogeography of the New Hebrides. Nature 181: 1253-1255.

Solem, A. (1976) Endodontoid Land Snails from Pacific Islands: Families Punctidae and Charopidae, Zoogeography. (Field Museum of Natural History: Chicago)

Soltis, D.E., Soltis, P.S., Chase, M.W., Mort, M.A., Albach, D.C., Zanis, M., Savolainen, V., Hahn, W.H., Hoot, S.B., Fay, M.F., Axtell, M., Swensen, S.M., Prince, L.M., Kress, W.J., Nixon, K.C., and Farris, J.S. (2000) Angiosperm phylogeny inferred from $18 \mathrm{~S}$ rDNA, $r b c \mathrm{~L}$ and $a t p \mathrm{~B}$ sequences. Bot. J. Linn. Soc. 133: 381-461.

Soulier-Perkins, A. (2000) A phylogenetic and geotectonic scenario to explain the biogeography of the Lophopidae (Hemiptera, Fulgoromorpha). Palaeogeog., Palaeoclim. Palaeoecol. 160: 239-254.

Specht, R.L. (1981) Biogeography of halophytic angiosperms (salt-marsh, mangrove and seagrass). Pp. 582-602 in A. Keast (ed.) Ecological Biogeography of Australia. (Junk: The Hague)

Specht, R.L. and Womersley, J.S. (1979) Heathlands and related shrublands of Malesia (with particular reference to Borneo and New Guinea). Pp. 321-338 in R.L. Specht (ed.) Heathlands and Related Shrublands. (Ecosystems of the World 9A) (Elsevier: Amsterdam)

Spethmann, W. (1987) A new infrageneric classification and phylogenetic trends in the genus Rhododendron (Ericaceae). Pl. Sys. Evol. 157: 9-31.

Stapf, O. (1894) On the flora of Mount Kinabalu in north Borneo. Trans. Linn. Soc. (ser. II, Botany) 4: 69-263.

Steenis, C.G.G.J. van. (1934a) On the origin of the Malaysian mountain flora. Part 1. Facts and statement of the problem. Bull. Jard. Bot. Buitenzorg III, 13: 135-262.

Steenis, C.G.G.J. van. (1934b) On the origin of the Malaysian mountain flora. Part 2. Altitudinal zones, general considerations and renewed statement of the problem. Bull. Jard. Bot. Buitenzorg III, 13: 288-417.

Steenis, C.G.G.J. van (1936) On the origin of the Malaysian mountain flora. Part 3. Analysis of floristic relationships (1st installment). Bull. Jard. Bot. Buitenzorg III, 14: 56-72.

Steenis, C.G.G.J. (1948) Ancistrocladaceae. Flora Malesiana 1, 4: 8-10.

Steenis, C.G.G.J. (1949) Podostemaceae. Flora Malesiana I, 4: 65-68.

Steenis, C.G.G.J. (1957) Lamiodendron, a new genus of Papuan Bignoniaceae. Nova Guinea new ser., 8: $379-381$.

Steenis, C.G.G.J. (1958) Rhizophoraceae: introductory section on ecology. Flora Malesiana I, 5: $431-441$.

Steenis, C.G.G.J. (1962a) The land-bridge theory in botany with particular reference to tropical plants. Blumea 11: 235-372.

Steenis, C.G.G.J. (1962b) The mountain flora of the Malaysian tropics. Endeavour October 1962: 183-193.

Steenis, C.G.G.J. (1963) Miscellaneous notes on New Guinea plants VII. 21. An interesting inland habitat of Sonneratia caseolaris (L.) Engl. Nova Guinea new ser. 12: 189. 
Steenis, C.G.G.J. van. (1964) Plant geography of the mountain flora of Mt. Kinabalu. Proc. Roy. Soc. London B 161: 7-38.

Steenis, C.G.G.J. van. (1972) The Mountain Flora of Java. (E.J.Brill: Leiden)

Steenis, C.G.G.J. van. (1977) Bignoniaceae. Flora Malesiana I, 8: 114-186.

Steenis, C.G.G.J. van. (1978a) Plant-geography of East Malesia. Bot. J. Linn. Soc. 79: 97-178.

Steenis, C.G.G.J. van. (1978b) Miscellaneous botanical notes XXV. Blumea 24: 479-484.

Steenis, C.G.G.J. van. (1979) The Rijksherbarium and its contribution to the knowledge of the tropical Asiatic flora. Blumea 25: 57-77.

Steenis, C.G.G.J. van. (1984) Three more mangrove trees growing locally in nature in freshwater. Blumea 29: 395-397.

Steenis, C.G.G.J. van. (1986) Sphenostemonaceae. Flora Malesiana I, 10: 145-149.

Stevens, P.F. (1970a) Agauria and Agarista: an example of tropical transatlantic affinity. Notes Roy. Bot. Gard. Edinb. 30: 341-359.

Stevens, P.F. (1970b) Calluna, Cassiope, and Harrimanella: a taxonomic and evolutionary problem. New Phytol. 69: 1133-1150.

Stevens, P.F. (1971) A classification of the Ericaceae: subfamilies and tribes. Bot. J. Linn. Soc. 64: 1-53.

Stevens, P.F. (1972) Notes on the infrageneric classification of Agapetes, with four new taxa from New Guinea. Notes Roy. Bot. Gard. Edinburgh 32: 13-28.

Stevens, P.F. (1974a) Circumscription and relationships of Dimorphanthera (Ericaceae), with notes on some Papuasian species. Contr. Herb. Austral. 8: 1-34.

Stevens, P.F. (1974b) A review of Calophyllum L. (Guttiferae) in Papuasia. Aust. J. Bot. 22: 349-411.

Stevens, P.F. (1976) The altitudinal and geographical distributions of flower types in Rhododendron section Vireya, especially the Papuasian species, and their significance. Bot. J. Linn. Soc. 72: 1-33.

Stevens, P.F. (1977) Additional notes on Dimorphanthera. J. Arnold Arbor. 58: 437-444.

Stevens, P.F. (1978a) A new species of Rhododendron (Ericaceae) from New Guinea. Adansonia ser. 2, 18: 55-57.

Stevens, P.F. (1978b) Generic limits in the Xeroteae. J. Arnold Arbor. 59: 129-155.

Stevens, P.F. (1980) A revision of the Old World species of Calophyllum (Guttiferae). J. Arnold Arbor. 61: 117-699.

Stevens, P.F. (1981) Phytogeography and evolution of the Ericaceae of New Guinea. Pp. 331-354 in J.L. Gressitt (ed.) Biogeography and Ecology in New Guinea. (Junk: The Hague)

Stevens, P.F. (1985) Malesian Vireya rhododendrons - towards an understanding of their evolution. Notes Roy. Bot. Gard. Edinb. 43: 63-80.

Stoddart, D.R., Bryan, G.W. and Gibbs, P.E. (1973) Inland mangroves and water chemistry, Barbuda, West Indies. J. Nat. Hist. 7: 33-46.

Stone, B.C. (1992) The New Guinea species of Pandanus sect. Maysops St. John (Pandanaceae). Blumea 37: 31-61.

Stonor, C.R. (1952) Rhododendrons in New Guinea. Roy. Hort. Soc. Rhododendron Year Book 1951-52 (at vireya.net)

Streimann, H. (1983) The Plants of the Upper Watut watershed of Papua New Guinea. (National Botanic Gardens: Canberra)

Sykes, W.R. (1998) Scaevola gracilis (Goodeniaceae) in the Kermadec Islands and Tonga. New Zealand J. Bot. 36: 671-674.

Symington, C.F. (1936) The flora of Gunong Tapis in Pahang: with notes on the altitudinal zonation of the forests of the Malay Peninsula. J. Malayan Branch Royal Asiatic Society. 14: 333-364.

Symon, D.E. (1984) Lycianthes subg. Polymeris sect. Asiomelanesia Bitter. Pacific Plant Areas 4: 248-249.

Symon, D.E. (1985) The Solanaceae of New Guinea. J. Adelaide Bot. Gard. 8: 1-171.

Symon, D.E. (1986) The phytogeography of New Guinea Solanum (Solanaceae). Blumea 31: 319-328.

Takeuchi, W. (1999a) Botanical results from the 1995 Bismarck-Ramu Expedition in New Guinea. Sida 18: 7541-782.

Takeuchi, W. (1999b) New plants from Crater Mt. Papua New Guinea, and an annotated checklist of the species. Sida 18: 941-986.

Takeuchi, W. (2000) Rhododendron loranthiflorum (Ericaceae) from mainland New Guinea: a distributional record and new subspecies. Notes Roy. Bot. Gard. Edinb. 57: 333-337.

Takeuchi, W. and Kulang, J. (1998) Vegetation Part 2. Botanical survey. Pp.36-39; 126-130 in A. Mack (ed.), A Biological Assessment of the Lakekamu Basin, Papua New Guinea (Conservation International: Washington D.C.)

Tan, B.C. (1998) Noteworthy disjunctive patterns of Malesian mosses. Pp. 1-7 in R. Hill and J.D. Holloway (eds) Biogeography and Geological Evolution of SE Asia. (Backhuys: Leiden) 
Taylor, R.W. (1967) A monographic revision of the ant genus Ponera Latreille (Hymenoptera: Formicidae). Pacific Insects Monograph 13: 1-112.

Temple, A. (1975) Ericaceae: Etude Architecturale de Quelques Espéces. (Thesis, Academie de Montpellier, Université des Sciences et Techniques du Languedoc)

Thin, N.N., Duc V.H., and van Welzen P.C. (1998) A revision of the Indochinese-Malesian genus Strophioblachia (Euphorbiaceae) Blumea 43: 479-487. (also at http://nhcml.leidenuniv.nl/euphorbs)

Thulin, M. and Warfa, A.M. (1987) The frankincense trees (Boswellia spp., Burseraceae) of northern Somalia and southern Arabia. Kew Bull. 42: 487-500.

Tolmachev, A.I. (1970) The roles of migration and autochthonous development in the formation of the high-mountain flora. Pp. 9-21 in V.N. Sukachev (ed.), Studies on the Flora and Vegetation of High Mountain Areas. (Academy of Sciences USSR/Israel Program for Scientific Translations: Jerusalem)

Turner, H. (1995) Cladistic and biogeographic analyses of Arytera Blume and Mischarytera gen. nov. (Sapindaceae) with notes on methodology and a full taxonomic revision. Blumea Suppl. 9: 1-230.

Vanderborght, T. (1989) Some observations on seedlings of Vigna vexillata (L.) A. Rich. (Fabaceae). Bull. Jard. Bot. Nat. Belg. 59: 191-187.

Vander Kloet, S.P. (1996) Taxonomy of Vaccinium sect. Macropelma. Syst. Bot. 21: 355-364.

Veldkamp, J.F. (1971) Oxalidaceae. Flora Malesiana I, 7: 151-171.

Veldkamp, J.F. (1979) A new Vaccinium (Ericaceae) from Papua New Guinea. Blumea 25: 479-480.

Veldkamp, J.F. (1982) Agrostis (Gramineae) in Malesia and Taiwan. Blumea 28: 199-228.

Veldkamp, J.F. (1991) Notes on Ericaceae from Papua New Guinea. Blumea 36: 161-164.

Veldkamp, J.F (2001) Spermatophytes and general subjects. Flora Malesiana Bull. 12. (at http://nhncml.leidenuniv.nl/fmbull/)

Verdcourt, B. (1979) A Manual of New Guinea Legumes. (Office of Forests: Lae)

Vermeulen, J.J. (1993) A taxonomic revision of Bulbophyllum sections Adelopetalum, Lepanthanthe, Macrouris, Pelma, Peltopus and Uncifera (Orchidaceae). Orchid Monographs 7: 1-324.

Vijverberg, K., Mes, T.H.M. and Bachmann, K. (1999). Chloroplast DNA evidence for the evolution of Microseris (Asteraceae) in Australia and New Zealand after long-distance dispersal from western North America. Amer. J. Bot. 86: 1448-1458.

Vink, W. (1957) Hamamelidaceae. Flora Malesiana I, 5, 363-379.

Vink, W. (1970) The Winteraceae of the Old World. I. Pseudowintera and Drimys - morphology and taxonomy. Blumea 40: 225-354.

Vink, W. (1995) Revision of Magodendron (Sapotaceae) with observations on floral development and morphology. Blumea 40: 91-107.

Vogel, E.F. de (1975a) Lophopyxis Hook. f. Pacific Plant Areas 3: 302-303.

Vogel, E.F. de (1975b) Kingiodendron Harms. Pacific Plant Areas 3: 306-307.

Vogel, E.F. de (1975c) Maniltoa Scheff. Pacific Plant Areas 3: 308-309.

Warburg, O. (1891) On the Papuan mountain flora. Bot. Jahrb. 13: 230-455.

Watson, L. (1964) Some remarkable inflorescences in the Ericales and their taxonomic significance. Anns. Bot. 28: 311-318.

Watson, L. (1967) Taxonomic implications of a comparative anatomical study of Epacridaceae. New Phytol. 66: 495-504.

Webb, D.A. (1972) Ericaceae. Flora Europaea 3.

Weiller, C.M. (1996a) Reassessment of Cyathodes (Epacridaceae). Aust. Syst. Bot. 9: 491-507.

Weiller, C.M. (1996b) Planocarpa (Epacridaceae), a new generic name. Aust. Syst. Bot. 9: 509-519.

Weiller, C.M. (1996c) Reinstatement of the genus Androstoma Hook. f. (Epacridaceae). New Zealand J. Bot. 34: 179-185.

Weiller, C.M. (1999) Leptecophylla, a new genus for species formerly included in Cyathodes (Epacridaceae). Muelleria 12: 195-214.

Weimarck, H. (1934) Monograph of the genus Cliffortia. (Kåkan Ohlsson: Lund)

Wells, P.V. (1969) The relation between mode of reproduction and extent of speciation in woody genera of the California chaparral. Evolution 23: 264-267.

Welzen, PC. van. (1993) Lepidopetalum Bl. Pacific Plant Areas 5: 176-177.

Welzen, P.C. van. (1994a) Taxonomy, phylogeny, and geography of Neoscortechinia Hook.f. ex Pax (Euphorbiaceae) Blumea 39: 301-318. (also at http://nhcml.leidenuniv.nl/euphorbs)

Welzen, P.C. van. (1994b) A taxonomic revision of S.E. Asian Chaetocarpus Thwaites (Euphorbiaceae). Rheedea 4: 93-101. (also at http://nhcml.leidenuniv.nl/euphorbs)

Welzen, P.C van. (1997) Increased speciation in New Guinea: tectonic causes? Pp. 363-387. in J. Dransfield, M.J.E. Coode \& D.A. Simpson (eds) Plant Diversity in Malesia III. (Royal Botanic Gardens: Kew) 
Welzen, P.C. van. (1998) Revisions and phylogenies of Malesian Euphorbiaceae: Subtribe Lasiococcinae (Homonoia, Lasiococca, Spathiostemon) and Clonostylis, Ricinus, and Wetria. Blumea 43: 131-164. (also at http://nhcml.leidenuniv.nl/euphorbs)

Welzen, P.C. van. (1999) Revision and phylogeny of subtribes Chrozophorinae and Doryxylinae (Euphorbiaceae). Blumea 44: 411-436. (also at http://nhcml.leidenuniv.nl/euphorbs)

Welzen, P.C. In press. Revision of Sauropus (Euphorbiaceae) in Malesia. (Available at http://nhcml.leidenuniv.nl/euphorbs)

Welzen, P.C. van, Piskaut, P., and Windadri, F.I. (1992) Lepidopetalum Blume (Sapindaceae): taxonomy, phylogeny, and historical biogeography. Blumea 26: 439-465.

Whitten, A.J., Damanik, S.J., Anwar, J. and Hisyam, N. (1987) The Ecology of Sumatra (Gadjah Mada University Press: Indonesia)

Wilde, W.J.J.O. de. (2000) Myristicaceae. Flora Malesiana I, 14: 1-634.

Willemse, L.P.M. (1982) A discussion of the Ehrharteae (Gramineae) with special reference to the Malesian taxa formerly included in Microlaena. Blumea 28: 181-194.

Wilson, J.B., Rapson, G.I., Sykes, M.T., Watkins, A.J. and Wilims, P.J. (1992) Distributions and climatic correlations of some exotic species along roadsides in the South Island, New Zealand. J. Biogeog. 19: 183-193.

Withers, R.M. (1984) The natural environment for Vireya rhododendrons. Roy. Hort. Soc. Rhododendrons with Magnolias and Camellias Yearbook 1983/4.

Withers, R.M. (1992) Rhododendron lochiae, Australia's only known native rhododendron species, its discovery, cultivation and hybridization. Rhododendron (J. Australian Rhododendron Soc.) 32. (at vireya.net)

Woods, P.J.B. (1978) Two Bornean rhododendrons. Notes Roy. Bot. Gard. Edinburgh 37: 157-159.

Zona, S. (1999) Revision of Drymophloeus (Arecaceae: Arecoideae). Blumea 44: 1-24.

Zug, G.R. (1999) Lizards of Fiji: natural history and systematics. Bishop Museum Bulletin in Zoology 2: $1-109$.

\section{Appendix:}

\section{Associates of Malesian Ericaceae cited by Sleumer $(1966,1967)$}

These will usually be at least co-dominant: Sphagnum L., Gleichenia Sm., Pteridium Scop., tree ferns (the Ericaceae are usually epiphytic on these), conifers (Agathis Salisb., Papuacedrus Li, Dacrydium Soland., Podocarpus Pers., Pinus L. (N Luzon)), Proteaceae (Grevillea R. Br.), Pandanaceae (Pandanus L.f.), Palmae (Metroxylon Rottb.), Fagaceae (Castanopsis (D. Don) Spach, Lithocarpus Blume, Quercus L.), Casuarinaceae (Casuarina Adans.), Nothofagaceae (Nothofagus Blume), Myrsinaceae (Rapanea Aubl.), Saxifragaceae (Quintinia A.D.C.), Myrtaceae (Leptospermum J.R. \& G. Forst., Xanthomyrtus Diels, Tristania R.Br.), Ternstroemiaceae/Symplocaceae (Eurya Thunb. and Symplocos Jacq.), and other Ericaceae (especially Vaccinium and Rhododendron).

Archbold (1942) recorded that a white-flowered liane of Dimorphanthera brought together numbers of flower-feeding birds, the most persistent being Charmosyna josefinae, Philemon meyeri, Myzomela eques, Melanocharis bicolor and Lorius. Stevens (1976) recorded Melidectes fuscus, M. princeps, and Ptiloprora pestriata (all Meliphagidae) feeding on, and probably pollinating, Rhododendron flowers. The berries of Vaccinium paradisearum are eaten by Oreopsittacus and Charmosyne (Loriidae) (Sleumer 1967). 
